UNIVERSIDADE DE SÃO PAULO

FACULDADE DE ECONOMIA, ADMINISTRAÇÃO E CONTABILIDADE DEPARTAMENTO DE ADMINISTRAÇÃO PROGRAMA DE PÓS-GRADUAÇÃO EM ADMINISTRAÇÃO

PROCESSO ESTRATÉGICO NA CRIAÇÃO E IMPLANTAÇÃO DA ESCOLA DE ARTES, CIÊNCIAS E HUMANIDADES DA USP: ESQUEMA ANALÍTICO E EVIDÊNCIAS EMPÍRICAS

Fernando Antônio Colares Palácios

Orientador: Prof. Dr. Martinho Isnard Ribeiro de Almeida

SÃo PAULO 
Prof. Dr. João Grandino Rodas

Reitor da Universidade de São Paulo

Prof. Dr. Reinaldo Guerreiro

Diretor da Faculdade de Economia, Administração e Contabilidade

Prof. Dr. Adalberto Américo Fischmann

Chefe do Departamento de Administração

Prof. Dr. Lindolfo Galvão de Albuquerque

Coordenador do Programa de Pós-Graduação em Administração 
FERNANDO ANTÔNIO COLARES PALÁCIOS

\title{
PROCESSO ESTRATÉGICO NA CRIAÇÃO E IMPLANTAÇÃO DA ESCOLA DE ARTES, CIÊNCIAS E HUMANIDADES DA USP: ESQUEMA ANALÍTICO E EVIDÊNCIAS EMPÍRICAS
}

\author{
Tese apresentada ao Departamento de \\ Administração da Faculdade de Economia, \\ Administração e Contabilidade da Universidade de \\ São Paulo, como um dos requisitos ao título de \\ doutor em administração.
}

Orientador: Prof. Dr. Martinho Isnard Ribeiro de Almeida

\author{
SÃO PAULO
}


Palácios, Fernando Antônio Colares

Processo estratégico na criação e implantação da Escola de Artes, Ciências e Humanidades da USP: esquema analítico e evidências empíricas / Fernando Antônio Colares Palácios. -- São Paulo, 2011. $204 \mathrm{p}$.

Tese (Doutorado) - Universidade de São Paulo, 2011.

Orientador: Martinho Isnard Ribeiro de Almeida.

1. Estratégia organizacional - Análise 2. Universidade pública I. Universidade de São Paulo. Faculdade de Economia, Administração e Contabilidade II. Título.

CDD -658.401 
Aos meus pais João e Neide, pelos ensinamentos sutis, mas que valeram para toda a vida.

À Priscilla, pelo amor, companheirismo e incentivo. Ao meu querido filho Fernando. 



\section{AGRADECIMENTOS}

Ao Prof. Dr. Martinho Isnard Ribeiro de Almeida, pela orientação e incentivo permanente no desenvolvimento do doutorado e da tese.

À Universidade do Estado do Pará (UEPA), pelo apoio financeiro e liberação.

Ao Programa de Pós-Graduação em Administração da FEA/USP, pela oportunidade de realização do doutorado.

Aos professores da FEA, em especial, aos professores Lindolfo Albuquerque, Silvio Aparecido, Rosa Fischer e André Fischer.

Aos gestores e professores da USP e da EACH, pelo fornecimento de informações fundamentais para o desenvolvimento da pesquisa.

Aos colegas da FEA, em especial, a todos aqueles que durante as disciplinas propiciaram momentos de rico aprendizado.

Aos membros do Grupo de Pesquisa em Planejamento Estratégico, pelas discussões, orientações e interesse acadêmico demonstrado ao longo dos três anos de elaboração da tese.

À minha família, pelo incentivo e apoio ao longo do doutorado.

Em especial à Priscilla, companheira de todos os momentos, pelo apoio irrestrito, além de leitora crítica e revisora da tese, fundamentais para sua conclusão.

E a todos aqueles que direta ou indiretamente contribuíram para a realização deste trabalho.

A Deus e Dom Bosco. 

“O caminho largo e aberto é apenas um entre muitos outros possíveis, mas tem suas vantagens. Ele nos permite ver uma grande variedade de atividades como partes de um mesmo processo dialético, e desenvolver uma interação criativa entre elas. Ele cria condições para o estabelecimento de um diálogo entre o passado, o presente e o futuro. Ele transpõe as fronteiras do espaço físico e social, revelando solidariedades entre artistas/especialistas e pessoas comuns, e também entre pessoas de diferentes lugares [...]. Ele nos proporciona uma visão mais ampla de nossa própria experiência, mostrando-nos que em nossa vida há mais do que imaginamos, e dá ao tempo em que vivemos mais intensidade e profundidade." 



\section{RESUMO}

Ao constatar a complexidade e a especificidade dos processos organizacionais em universidades, a tese procurou responder à questão central de como ampliar a capacidade de análise, interpretação e explicação do processo estratégico ocorrido quando da criação e implantação da Escola de Artes, Ciências e Humanidades (EACH), na Universidade de São Paulo (USP). Para tanto, o objetivo geral foi elaborar um esquema analítico capaz de estruturar os elementos intervenientes e propiciar significados aos pesquisadores e aos estrategistas sobre o processo ocorrido na EACH. Propunha-se, de forma específica, responder questões tipo: como caracterizar o processo estratégico, quais os agentes, os recursos organizacionais e as relações contextuais envolvidos e de que forma se combinaram nas ações. A estratégia foi analisada como uma construção social, na qual o ser humano é um potencial agente de transformação social. A tese fundamentou-se nas teorias sociológicas de Giddens (2003) e Sztompka (2005) e nos estudos organizacionais sobre processo. Ainda no campo da estratégia, explorou tipologias de formação e implementação. Utilizando metodologia interpretativa procurou identificar as contradições dialéticas geradas pela interação de agentes em eventos delimitados, imersos em uma realidade histórica, social e cultural. Foram realizadas entrevistas, pesquisa documental e técnicas de observação durante dois anos para a obtenção dos dados da pesquisa. O esquema analítico foi elaborado a partir de três dimensões principais: agentes, contexto e sistemas organizacionais. Na sua aplicação, foram analisados dois eventos constituintes do episódio de criação e implantação da nova unidade: 1) elaboração do projeto da EACH e 2) elaboração do curso de mestrado em sistemas complexos. Os resultados podem ser assim resumidos: a) o esquema analítico mostrou-se capaz de captar e retratar a complexidade do processo na $\mathrm{EACH}$; b) o processo estratégico, nos eventos analisados, caracterizou-se como racional e formal, em determinados momentos, e como um processo negociado e em construção permanente; c) gestores e professores foram agentes principais, sendo influenciados por valores como autonomia e legitimidade; d) fatores organizacionais como cultura da USP, formas de liderança, poder e estruturas formais e não-formais mostraram-se muito influentes, assim como, o contexto histórico e social; e) constatou-se que os modelos organizacionais de análise da universidade conseguem captar apenas partes da complexidade do processo. São apresentadas proposições para a USP no intuito de contribuir para a efetivação do projeto. Espera-se que a tese contribua para ampliar o campo de pesquisa integrando os estudos educacionais aos estudos organizacionais.

Palavras-chave: Processo estratégico. Universidade. Esquema analítico. 



\begin{abstract}
After finding the complexity and specificity of organizational processes in Universities, this paper intends to answer the main question of how to increase the capacity of analysis, interpretation and explanation of the strategic process, that took place when the Arts, Science and Humanities School - EACH - was created and implanted in São Paulo University. In order to achieve that purpose, the main goal was to elaborate an analytical schema, capable of structuring the elements involved, and also to give meanings to strategy researchers and to strategists about the process that took place at EACH. It also intends to answer questions such as: how to characterize the strategic process, the agents, the organizational resources and the contextual relations involved, and how they would match in action. The strategy was analyzed as a social construction, in which the human being is a potential agent of social transformation. The thesis is based on the sociological theories of Giddens (2003) and Strompka (2005), so as on organizational studies about processes (1992; 1995). It also explored types of training and implementation. Making use of interpretative methodology, there was an effort to identify the dialectical contradictions created by the agents' interaction in delimited events, located on a historical, social and cultural reality. Interviews, documentary research and observation techniques were made during the period of two years in order to acquire data for the research. The analytical schema was formulated based on three main dimensions: agents, context and organizational systems. On the usage of the scheme, two events which are part of the process of creation and implementation of the new unit were analyzed: 1) building the EACH project and 2) building a master course based on complex systems. The outcomes can be summarized as follows: a) the analytical scheme proved to be able to capture and to portray the complexity of the process in EACH; b) the strategic process on the analyzed events, was characterized as rational and formal, in certain moments, and as negotiated and ongoing; c) managers and professors were agents being influenced by values such as autonomy and legitimacy; d) organizational factors as forms of leadership, power and formal and non-formal structures proved to be influential, as well as, the historic and social context; e) it was found that the organizational models of analysis of the university can capture only parts of the complexity of the strategic process. Propositions to USP are here presented as an attempt to contribute to the effectiveness of the project. It is expected that a research area can be improved being able to integrate the educational studies to the organizational studies.
\end{abstract}

Key words: Strategic Process. University. Analytical Scheme. 



\section{SUMÁRIO}

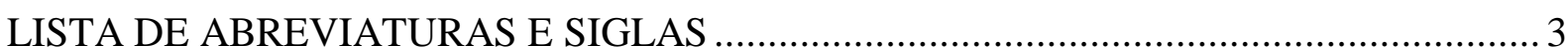

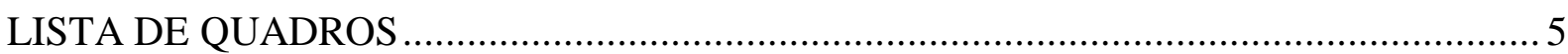

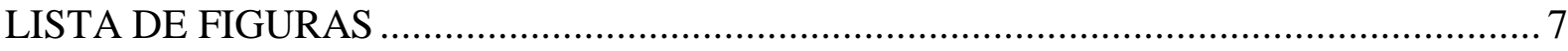

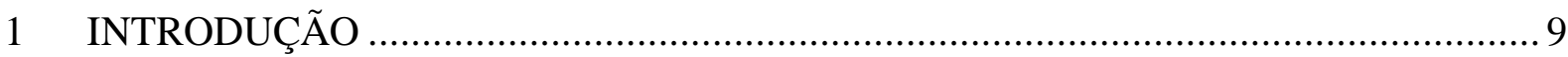

1.1. Contextualização e Definição da Situação Problema ….......................................... 10

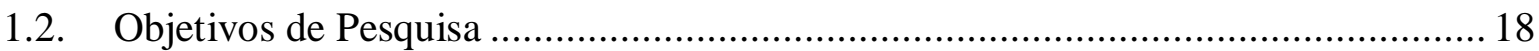

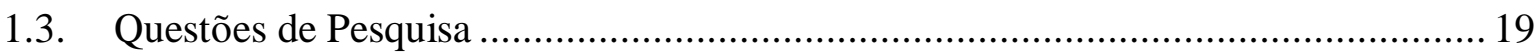

1.4. Justificativa: Relevância e Ineditismo .................................................................. 19

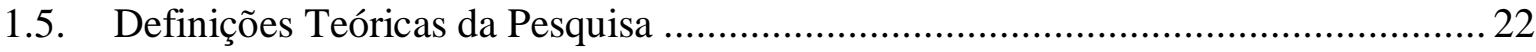

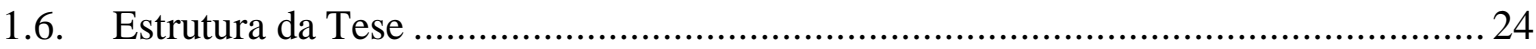

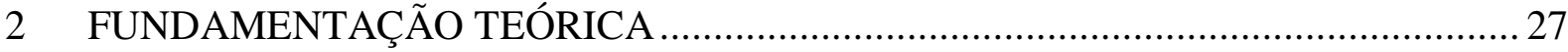

2.1. Universidade Moderna: Contexto, Organização e Agentes ................................... 28

2.2. Teorias de Fundamentação da Gestão como Prática Social .................................... 49

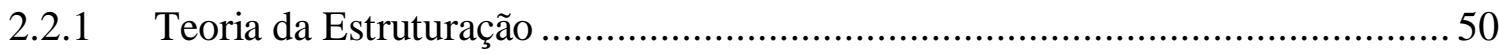

2.2.2 O Modelo de Transformação Social de Piotr Sztompka................................... 57

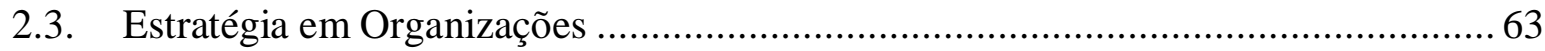

2.3.1 Abordagem de Estratégia Como Processo .................................................... 85

2.3.2 Estratégia nas Organizações Educacionais ................................................. 89

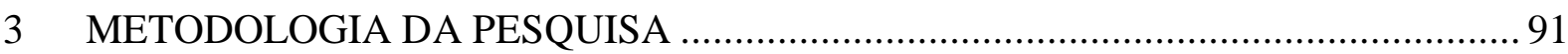

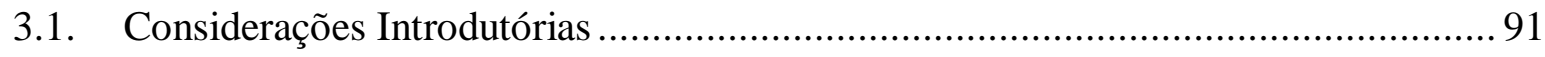

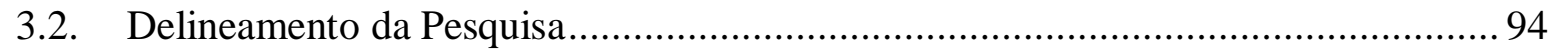

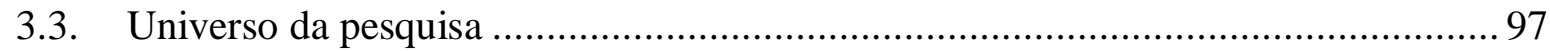

3.4. Instrumentos de Coleta e Análise de Dados.......................................................... 98

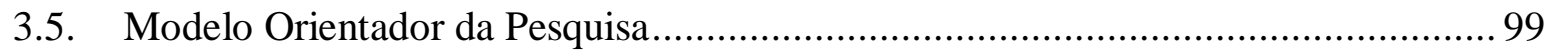

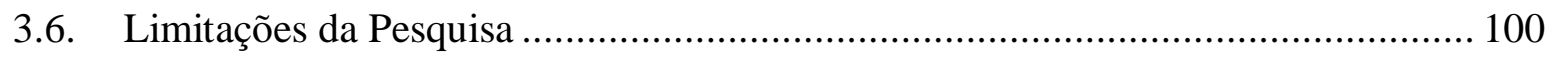

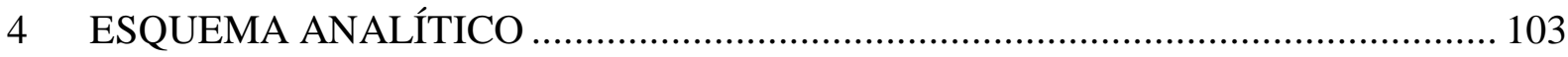

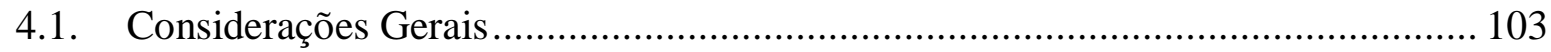

4.2. Esquema Analítico: Dimensões, Conceitos, Dinâmica e Visão Geral ................... 108

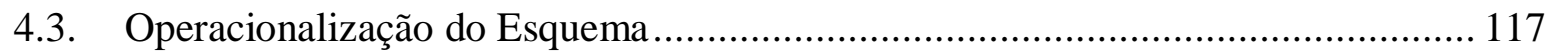

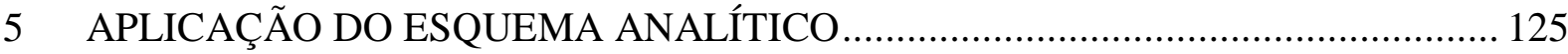

5.1. Evento 1: A Elaboração do Projeto de Criação EACH....................................... 129 
5.2. Evento 2: Elaboração do Projeto do Curso de Mestrado em Sistemas Complexos. 153

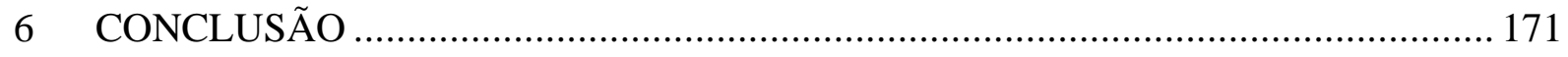

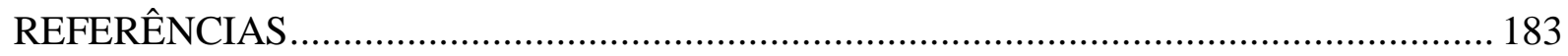

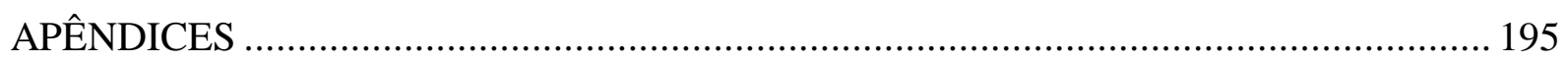

Apêndice 1: Roteiro de Entrevista - Evento 1 - Dirigentes da USP .............................. 196

Apêndice 2: Roteiro de entrevista - Evento 2 - Professores do mestrado em sistemas

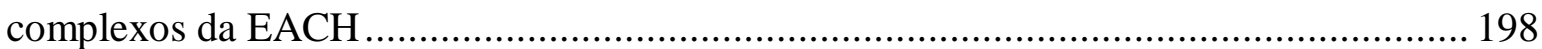




\section{LISTA DE ABREVIATURAS E SIGLAS}

CAPES: Coordenação de Aperfeiçoamento de Pessoal de Nível Superior EACH: Escola de Artes, Ciências e Humanidades

LDB: Lei de Diretrizes e Bases da Educação Nacional

UFU: Universidade Federal de Uberlândia

UEPA: Universidade do Estado do Pará

UFMG: Universidade Federal de Minas Gerais

UFSM: Universidade Federal de Santa Maria

UNB: Universidade de Brasília

USP: Universidade de São Paulo

PPI: Projeto Pedagógico Institucional

PPC: Projeto Pedagógico de Curso

IES: Instituição de Ensino Superior

CO: Conselho Universitário da USP

PSDB: Partido da Social Democracia Brasileira

UNICAMP: Universidade de Campinas

UNESP: Universidade Estadual Paulista

CRUESP: Conselho dos Reitores das Universidades Estaduais Paulistas

ADUSP: Associação dos Docentes da USP

CERT: Comissão Especial de Regime de Trabalho 


\section{LISTA DE QUADROS}

Quadro 1 - Modelo Sztompka (Parte 1) ........................................................................... 58

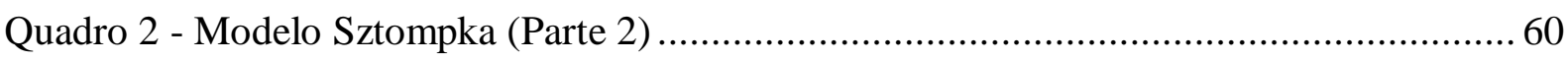

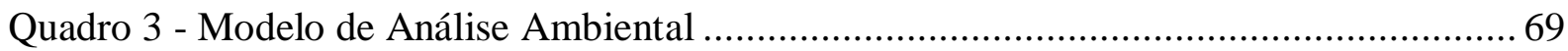

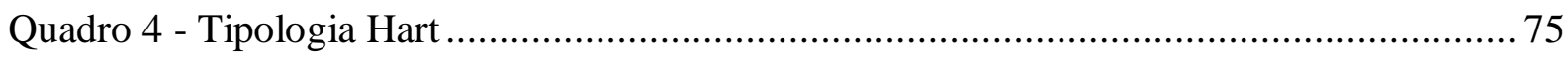

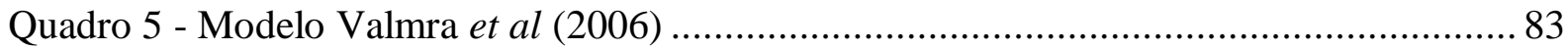

Quadro 6 - Teorias (motores) de processo de mudança de Van de Ven ................................ 86

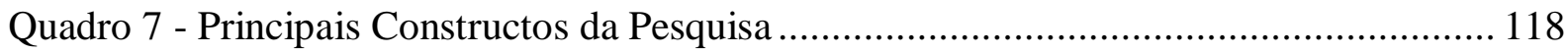

Quadro 8 - Trajetória do Episódio de Criação e Implantação da EACH ............................. 125

Quadro 9 - Perfil dos Entrevistados ......................................................................... 128

Quadro 10 - Entrevistas e Visitas Realizadas ................................................................. 128

Quadro 11 - Caracterização dos Agentes - evento 1 .......................................................... 138

Quadro 12 - Caracterização dos Agentes - Evento 2 ....................................................... 155 


\section{LISTA DE FIGURAS}

Figura 1 - Executando as Estratégias: Decisões e Ações ..................................................... 78

Figura 2 - Contexto das Decisões de Execução.................................................................... 79

Figura 3 - Teorias de Processo de Desenvolvimento e Mudança Organizacional .................. 87

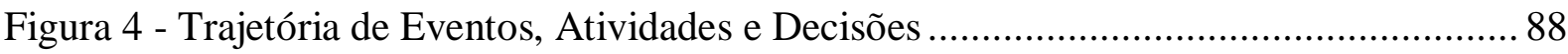

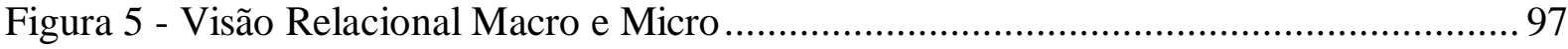

Figura 6 - Modelo Orientador da Pesquisa.................................................................... 100

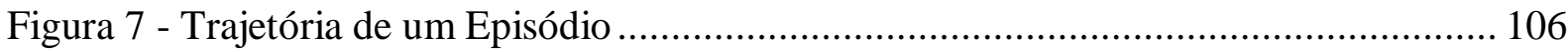

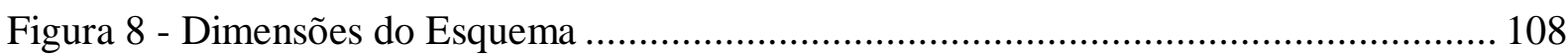

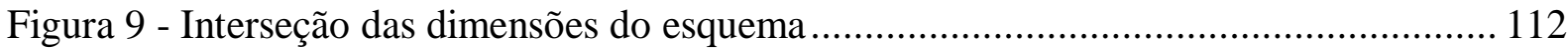

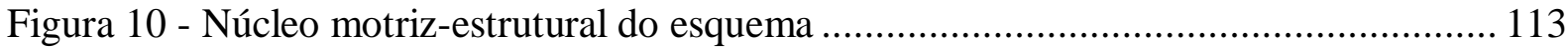

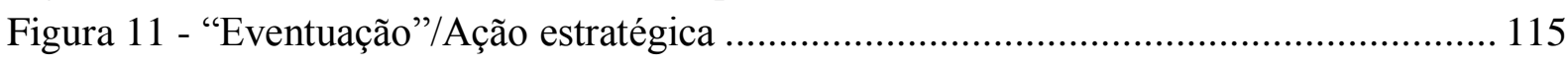

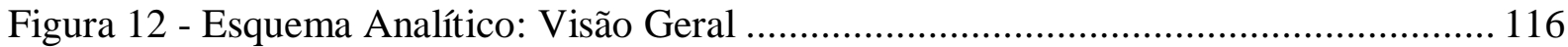

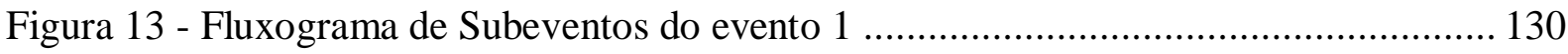

Figura 14 - Fluxograma de Subeventos do Evento 2 ................................................. 153 


\section{INTRODUÇÃO}

A instituição de educação superior do tipo universidade, de caráter público, objeto desta pesquisa, caracteriza-se no Brasil, segundo a Lei de Diretrizes e Bases da Educação (LDB/ Lei 9394/96), pela indissociabilidade entre ensino, pesquisa e extensão, pela existência de pós-graduação stricto sensu e pela universalidade das áreas de conhecimento nas quais atua.

Trata-se de uma organização estrutural e funcionalmente complexa (BALDRIDGE et al, 1977) e pluralística (DENIS et al, 2007). Sua complexidade e pluralismo decorrem em razão de seus objetivos múltiplos e muitas vezes divergentes que envolvem desde a produção e a difusão do conhecimento e o desenvolvimento tecnológico, até a responsabilidade social, ou seja, a manutenção e a formação de valores sociais responsáveis pelo perfil da sociedade (RODRIGUES et al, 2006).

Complexidade e pluralismo estão também relacionados ao poder difuso existente no interior da estrutura organizacional formal e informal e à maneira de atuação de seus agentes fundamentada no conhecimento especializado dos processos de trabalho (DENIS et al, 2007) o que lhes garante autonomia, porém, muitas vezes orientando suas ações por valores contraditórios aos projetos estratégicos da instituição.

Completando essas características da universidade destaque-se a sua especificidade enquanto organização educacional, o que para Lima (2008) implica em sua revalorização como objeto de estudo sociológico-organizacional. Comunga com a interpretação de outros autores (DENIS et al, 2007; MINTZBERG, 2006), sobre a necessidade de construir e utilizar modelos específicos de análise capazes de apreender e estruturar as diversas situações e fatores envolvidos no desenvolvimento de processos nesse tipo de organização, na tentativa de melhor interpretá-los e explicá-los.

Um desses processos organizacionais é o de formulação/elaboração e implementação de estratégias, foco central da tese, analisado a partir do episódio de criação e implantação de uma nova unidade em uma universidade pública brasileira. 


\subsection{Contextualização e Definição da Situação Problema}

Para uma contextualização introdutória da universidade pública no Brasil pode-se adotar, de forma similar a outros pesquisadores (RODRIGUES et al, 2006; SCHWARTZMAN, 2008; MINTZBERG, 2006), uma explanação fundamentada em modelos analíticos sociais e organizacionais. Ressalte-se, porém, que a característica comum desses modelos é o fato de priorizarem em suas análises da universidade determinadas variáveis em detrimento de outras, possibilitando uma visão mais focalizada dos fenômenos em estudo, porém reducionista e incompleta, daí a necessidade de utilizá-los em conjunto para obter uma visão mais abrangente.

Os modelos sociais interpretam a universidade a partir de suas finalidades e funções no contexto social no qual está inserida, salientando aspectos como; o nível de prioridade dado ao ensino e à pesquisa, a relação da universidade com empresas e indústrias e as características demográficas e geográficas da instituição. Possuem denominações do tipo: acadêmico, internalista, externalista, massificado e de classe internacional (SCHWARTZMAN, 2008; RODRIGUES et al, 2006).

Os modelos organizacionais do tipo burocrático-profissional, adhocracia, político, colegial e de anarquia organizada, direcionam as lentes das análises para aspectos internos à organização, com destaque para as configurações estruturais e para a forma como acontecem os processos decisórios na universidade ${ }^{1}$.

Apesar da ênfase normativa na indissociabilidade entre ensino, pesquisa e extensão, estudos têm comprovado ser o ensino e a preocupação com a formação profissional as atividades centrais de grande parte das universidades brasileiras (PEREIRA, 2009), seguindo um modelo denominado internalista (RODRIGUES et al, 2006). Segundo esta denominação, "a classificação geral do conhecimento humano, também responsável pela geração das profissões, tem determinado a estrutura das universidades em departamentos acadêmicos" (RODRIGUES et al, 2006, p. 3), sendo estes, em muitas universidades públicas no Brasil, os principais responsáveis pelo estabelecimento e cumprimento dos objetivos e metas das

\footnotetext{
${ }^{1}$ A definição dos modelos de interesse para a tese será feita no capítulo seguinte. À título introdutório, em razão das características da universidade pública no Brasil, são apresentadas breves considerações sobre os modelos internalista, acadêmico e burocrático-profissional.
} 
unidades universitárias, obtendo em razão disso autonomia quase que plena para decidir sobre questões acadêmicas.

O modelo internalista apresenta algumas similaridades com o modelo acadêmico (SCHWARTZMAN, 2008), sendo que este alia a atividade de ensino e a preparação dos estudantes para o trabalho profissional aos grandes ideais da ciência e da pesquisa pura. Guarda em si também a idéia de homogeneidade do sistema de ensino superior representada no imaginário da sociedade como uma entidade única e autônoma de governos, a universidade. Os modelos internalista e acadêmico têm suas origens no modelo napoleônico e no humboltiano, respectivamente, que influenciaram a formação do ideal de um tipo único de universidade pública brasileira.

A predominância do modelo único de universidade acadêmica no Brasil, representado principalmente pelas universidades públicas federais e estaduais, imprimiu, principalmente ao longo da segunda metade do século passado, homogeneidade normativa e funcional ao sistema $^{2}$.

Na visão de Schwartzman (2008), a resistência à mudança e à diversificação de modelos nas universidades públicas tem um viés ideológico, sendo coordenado por um movimento que une professores, governantes, estudantes e sindicatos tendo como motes principais a indissociabilidade do ensino, da pesquisa e da extensão e o princípio da universidade pública e gratuita ${ }^{3}$.

Percebeu-se que, ao final da década de noventa, organizações de todos os tipos e orientações foram criadas, aproveitando a maior flexibilidade dada pela Lei de Diretrizes e Bases da Educação Nacional (LDB/1996) para a abertura e estruturação de novas instituições e cursos e

\footnotetext{
${ }^{2}$ Para Schwartzman (2008, p. 30-31) "essa homogeneidade pode ser traduzida em leis, regimentos, carreiras, cursos obrigatórios e anos de estudo, exigência de diplomas e publicações, muitas vezes só para cumprir formalidades legais, teve um custo incalculável para o país ao longo dos anos, que nem conseguiu criar um sistema educacional que efetivamente se aproximasse do modelo único, e nem permitiu que outras atividades educativas, talvez mais simples e baratas, mas de efeitos significativos, pudessem ser bem desenvolvidas".

${ }^{3} \mathrm{Na}$ Universidade de São Paulo, onde esta pesquisa foi desenvolvida, no período de 2008/2010, os funcionários realizaram várias greves por motivos salariais (isonomia salarial entre funcionários e professores, aumento salarial acima da inflação, etc.), mas também por serem contrários à criação da Universidade Virtual e de cursos à distância em parceria com o governo estadual, além de críticas ao processo de criação da USP Leste, caracterizando um contexto em que mudança e inovação representam ameaças às "conquistas" anteriormente alcançadas pelos sindicatos.
} 
para a implantação de inovações acadêmicas e estruturais. Esse novo contexto fez surgir, não de imediato, mas apenas no século seguinte, uma maior diversidade de tipos organizacionais e o aparecimento de experiências acadêmicas inovadoras em universidades públicas e privadas.

Em uma abordagem mais organizacional, para Mintzberg (2006) e seguidores, as universidades apresentam uma configuração estrutural que pode ser caracterizada como "burocracia profissional". Ela é resultado de um trabalho padronizado, o que leva ao comportamento predeterminado, mas também, de um trabalho especializado e controlado diretamente pelos operadores.

O controle sobre seu próprio trabalho permite aos gestores e professores uma ação independente e necessária ao processo educacional, mas pode tornar-se problemática à gestão organizacional, já que essa autonomia, entre outras coisas, pode levar ao isolamento, à falta de diálogo entre as unidades e à resistência em seguir orientações estratégicas (DENIS et al, 2007).

A partir dessa análise introdutória da estrutura e do funcionamento da universidade, pode-se afirmar, inicialmente, que isomorfismo estrutural ${ }^{4}$, ou seja, a predominância de uma estrutura organizacional similar entre as diversas organizações no setor social ${ }^{5}$ universitário, e elevado grau de independência entre unidades e departamentos e entre os professores e a gestão caracterizam a organização universitária pública brasileira (MEYER Jr., 2000). Isso, em uma primeira análise, pode resultar em uma tendência ao imobilismo ou à inércia organizacional e em dificuldades para criar e desenvolver projetos acadêmicos inovadores nos diferentes contextos que compõem as universidades em sua complexidade.

\footnotetext{
${ }^{4}$ Para os teóricos institucionalistas, o isomorfismo é o meio que a organização desenvolve para manter a conformidade ambiental, ao proteger a sua estrutura, efetuando ligações entre procedimentos administrativos e técnicos. Ao demonstrar que atua de acordo com normas definidas e racionalizadas na sociedade, "a organização obtém legitimidade, e assegura a sua sobrevivência e capacidade de expansão por meio da criação de oportunidades para alocar mais recursos e implementar inovações" (FONSECA; MACHADO-DA-SILVA, 2002, p. 101). Portanto, a legitimidade pode ser a senha para que uma organização ouse e inove. Entretanto, o que se observa no campo universitário brasileiro, nas últimas décadas, é que mesmo as universidades legitimadas pela sociedade realizam poucas experiências inovadoras contribuindo para a homogeneidade estrutural no setor social.

${ }^{5}$ Setor social é a denominação dada pelos institucionalistas para o ambiente em que operam organizações em um mesmo campo, para fabricar produtos e prestar serviços similares e que mantêm ligação em nível local, regional, nacional e internacional (SCOTT; MEYER, 1991).
} 
Em contraste com a homogeneidade do modelo acadêmico e com o isomorfismo estrutural e funcional característicos da organização universitária brasileira no século passado, pesquisadores de diferentes correntes teóricas concordam sobre a necessidade da diversificação das formas de atuação da universidade para atender às transformações sociais que vem ocorrendo no mundo, resultando certamente em mudanças nos seus objetivos e atividades, na sua estrutura organizacional e no seu modo de funcionamento (BUARQUE, 1989; SANTOS, 1997; DEMO, 1995).

Nos últimos anos, a necessidade por mudança tem-se tornado premente em razão do crescimento de pressões oriundas dos diversos segmentos da sociedade e também de segmentos internos à universidade. (SANTOS, 1997; CORBUCCI, 2007; SCHWARTZMAN, 2008).

Ressalte-se que essas pressões, muitas vezes apresentam demandas conflitantes entre si, o que pode dificultar a elaboração de projetos estratégicos efetivos. Apenas para citar alguns exemplos, propõe-se a ampliação do acesso a novos estudantes, mas com a manutenção da indissociabilidade entre as funções de ensino, pesquisa e extensão; discute-se fomentar um perfil organizacional mais empreendedor, porém mantendo as atuais características de universidade pública e de burocracia estatal; há consentimento sobre a necessidade de mudar, porém não há acordo sobre a necessidade de transformação radical de estruturas e formas de agir já legitimadas.

Tais processos contraditórios têm resultado em crises e dissidências internas (SANTOS, 1997; ZABALZA, 2004) que afetam a hegemonia ${ }^{6}$ e a legitimidade ${ }^{7}$ da universidade no contexto social, o que reforça a hipótese da necessidade de se buscar empreender processos de formulação e implementação de estratégias que possam resultar em mudanças.

\footnotetext{
${ }^{6}$ Hegemonia: a crise de hegemonia pode ser assim exemplificada: a demora na universidade pública em encontrar soluções para a ampliação do ingresso de novos estudantes na graduação e na pós-graduação e em elaborar e desenvolver cursos com características mais próximas à realidade do mercado de trabalho atual permitiu o aparecimento de outras organizações (inclusive no interior das próprias universidades - as fundações) que passaram a ocupar um espaço antes hegemônico.

${ }^{7}$ A crise de legitimidade enfoca "o espectro social dos destinatários dos conhecimentos produzidos e, portanto, a democraticidade da transmissão destes" (SANTOS, 1997, p. 192). Para o autor, [...] quando a procura por educação deixa de ser uma reivindicação utópica e passa a ser uma aspiração socialmente legitimada, a universidade só pode legitimar-se, satisfazendo-a (1997, p. 211). Destaque-se que a crise de legitimidade de Santos, possui certas diferenças em relação à legitimidade destacada pela abordagem institucionalista.
} 
Acredita-se que esse processo estratégico deva ser construído a partir da elaboração de projetos acadêmicos e organizacionais que se ajustem melhor às diversas realidades em que as universidades atuam, que não sejam simplesmente importados de outros setores, ou que copiem experiências exitosas sob certas situações, ou ainda que simplesmente reajam às pressões sem considerar idéias e valores instituídos pelo curso da história de cada instituição.

Importante nesse ponto esclarecer que na tese, estratégia organizacional será considerada como um "fluxo de práticas sociais inseridas em contextos organizacionais específicos e sociais mais amplos, existindo fluxos simultâneos em uma mesma organização" (CARRIERI et al, 2008. p. 11) e que seu estudo será realizado a partir das perspectivas processual e prática. Isto significa considerá-la como uma construção social, na qual o ser humano é um potencial agente de transformação social.

As pesquisas na perspectiva processual focam como a estratégia se desenvolve em uma organização, ao longo do tempo. Nas palavras de Van de Ven (1992), processo pode ser definido como uma sequência de eventos que descreve como as coisas mudam ao longo do tempo. Esta abordagem reconhece a relevância tanto do contexto interno das organizações, como do contexto externo para o desenvolvimento da estratégia. Segundo autores como Van de Ven (1992) e Chakravarthy e Doz (1992), o foco da implementação está no processo de mudança, sendo este inerente ao seu desenvolvimento.

Dessa forma, nesta abordagem, a estratégia é igualada à lógica do comportamento da empresa em um "fluxo de ações" (MINTZBERG, 1978). "A lógica é estabelecida pela referência ao relacionamento dialético entre a organização, seu sistema interno e seu ambiente" (WHIPP, 2004, p. 236).

A perspectiva como prática origina-se da processual, porém pretende ir além desta, ao procurar entender a construção da estratégia de uma organização a partir das práticas dos indivíduos no dia-a-dia (WHITTINGTON, 2004). Segundo os autores desta corrente, é na medida em que os atores organizacionais interagem entre si nas rotinas organizacionais que a estratégia se constrói e a organização se forma - processo contínuo, em gerúndio, o que os levou a cunhar termos como strategizing (fazendo a estratégia) e organizing (fazendo a 
organização) para melhor descrever suas interpretações (WHITTINGTON, 2003; WHITTINGTON, 2006).

Aproxima-se da abordagem dos sistemas de ação concretos (FREIDBERG, 1993) que situam os atores em contextos de ação contingentes no qual ocorre a construção política que mediatiza e torna possível a cooperação concreta à volta de um problema igualmente concreto. Considera a gestão como prática social, na qual importa a classe de ações nas quais os praticantes estão engajados como membros de uma comunidade de prática (REED, 1989).

Destaque-se ainda, a associação com o acadêmico e a preocupação com os efeitos que a estratégia em uma perspectiva processual na universidade implica, de acordo com Carbonel (2002, p. 19):

Um conjunto de intervenções, decisões, processos, com certo grau de intencionalidade e sistematização, que tratam de modificar atitudes, idéias, culturas, conteúdos, modelos e práticas pedagógicas. E, por sua vez, introduzir, em uma linha renovadora, novos projetos e programas, materiais curriculares, estratégias de ensino e aprendizagem, modelos didáticos e outra forma de organizar e gerir o currículo, a escola e a dinâmica de classe.

Imersas nesse contexto apresentado, as universidades públicas brasileiras vêm procurando formular projetos e planos centrados em mudanças nos seus processos acadêmicos e administrativos. Supõe-se que tais projetos possam ser dirigidos e efetivados de acordo com as intenções e escolhas iniciais dos dirigentes, mas pouco se sabe sobre como são formulados e implementados, quem participa do processo, quais os condicionantes implicados na sua formulação e implementação e de que forma podem ser mais bem conduzidos.

$\mathrm{Na}$ realidade, nesses momentos de redefinição estratégica e de implantação de um novo projeto percebe-se na universidade uma exacerbação de sua complexidade social e organizacional, resultando em um fenômeno como uma "sequência de [eventos] e processos multifacetados, e com multiestágios, os quais envolvem a interação dinâmica de muitas partes, em níveis diferentes de abstração" (AYAS, 2001, p. 218) e que podem inviabilizar a efetividade ${ }^{8}$ do projeto ou a sua própria continuidade.

\footnotetext{
${ }^{8}$ Seguindo a linha de Duncan e Weis (1979), ao encararem a organização como um sistema de ação intencional, definem o conceito de efetividade como o grau em que as ações organizacionais levam aos resultados esperados (apud AYAS, 2001).
} 
Para enfrentar essa complexidade da universidade pública no Brasil, Almeida (2004, p. 18) afirma que "é preciso construir uma arquitetura, desenvolver um modelo de processo e uma forma de condução da estratégia" capaz de contemplar os conflitos internos e diminuir os riscos de falhar no processo de implementação.

Uma melhor interpretação de como ocorre o processo estratégico, analisando como são formuladas/elaboradas e implementadas estratégias (SCHENDEL, 1992) em eventos localizados no tempo e no espaço, pode contribuir para a apreensão dos diversos elementos e fatores que participam ou influenciam no desenvolvimento e nos resultados/efeitos da estratégia pretendida e dessa forma possibilitar uma melhor gestão.

Pois, como afirma Machado-Da-Silva (2004, p. 251- 256):

\begin{abstract}
Não se avalia, sistematicamente, o processo concreto de formulação, difusão e implementação de estratégias em organizações no contexto econômico e sociocultural brasileiro, isto é: como ocorre a tomada de decisão estratégica; os atores e os recursos organizacionais envolvidos; as interpretações e os conhecimentos técnico-científicos utilizados; o nível de aceitação ou de resistência nas diversas instâncias da organização; as relações contextuais com outras organizações e com as esferas institucionais em seus diversos níveis.
\end{abstract}

Esta pesquisa busca oferecer contribuição neste sentido. Associa o estudo de teorias de análise sociológica e organizacional à experiência viva da criação e implantação de uma nova unidade na Universidade de São Paulo (USP), a Escola de Artes, Ciências e Humanidades $(\mathrm{EACH})$.

Denominada de USP Leste, em razão de sua localização na capital paulista, iniciou suas atividades no ano de 2005, porém, o começo do processo de definição de sua criação e da formulação de seu projeto data do ano de 2002. Constituiu-se, principalmente, com o objetivo de ampliar e diversificar o acesso de novos estudantes à USP, sem perda de qualidade. Ao mesmo tempo, significou a experimentação de ações inovadoras, como a criação de cursos com novos perfis profissionais, de nova estrutura organizacional e de processos acadêmicos e administrativos diferenciados.

Resumindo a lógica analítica até aqui apresentada. Ressalta-se a complexidade e a especificidade contextual e organizacional da universidade pública brasileira no qual se destacam a existência de múltiplos objetivos, de poder difuso e de trabalho baseado no 
conhecimento de processos, o que a caracteriza como uma organização pluralística (DENIS et al, 2007). Como organização pluralística apresenta um complexo desafio tanto para os teóricos quanto para os profissionais da estratégia "porque a própria natureza da estratégia como normalmente entendida (uma explícita e unificada direção para a organização) parece contradizer a dinâmica natural desta organização" (DENIS et al, 2007, p. 179), tendo de fazer-se a opção de analisar a estratégia como fluxo de eventos/ações em contextos localizados, o que para a sua interpretação exige que sejam estruturados os elementos e fatores intervenientes no processo.

Destaque-se ainda a especificidade do processo em cada organização, pois, segundo Nicolau (2001), a tarefa de compreender os processos que dão origem às estratégias está também relacionada à questão de saber o que, de fato, elas são, ou seja, a forma como surgem e são implementadas "não sendo um processo idêntico em todas as organizações resultando antes de uma conjugação de fatores externos e de condições organizacionais e humanas que configuram cada situação particular" (NICOLAU, 2001, p. 7).

Acredita-se que analisar e buscar entender o processo estratégico nessa perspectiva requer a utilização de novos instrumentos analíticos. Como esquemas analíticos ou modelos construídos tendo em vista essas características organizacionais elencadas, que sejam capazes de relacionar a teoria aos dados obtidos em circunstâncias específicas. Nas palavras de Van de Ven (2000, p. 144), um esquema "provê caminhos para representar alguns aspectos do mundo e alguns aspectos de nossas teorias sobre o mundo", ou na visão de Sztompka (2005), serve como um instrumento cognitivo que deve ser avaliado por sua eficácia e poder heurístico.

Do exposto emerge o problema da pesquisa:

Como pode ser ampliada a capacidade de análise, interpretação e explicação, considerando sua complexidade e especificidade, do processo estratégico ocorrido quando da criação e implantação do projeto de uma nova unidade na Universidade de São Paulo, no período compreendido de 2002 a 2010, a partir da percepção de um grupo de agentes envolvidos no processo? 
Do problema de pesquisa originaram-se os objetivos da tese.

\subsection{Objetivos de Pesquisa}

\section{Objetivo Geral:}

- Elaborar um esquema analítico capaz de estruturar os elementos intervenientes e indicar significados aos pesquisadores e aos estrategistas, possibilitando uma melhor interpretação e explicação do processo estratégico ocorrido quando da criação e implantação da Escola de Artes, Ciências e Humanidades (EACH), na Universidade de São Paulo (USP).

\section{Objetivos Específicos:}

- Observar a dinâmica de funcionamento da EACH para identificar os agentes principais no processo e para contextualizar no tempo e no espaço os eventos mais significativos que constituíram o episódio de criação e de implantação da EACH;

- Identificar, a partir da reconstrução das experiências dos agentes e dos significados socialmente construídos, quais os fatores contextuais intervenientes, os sistemas organizacionais mobilizados e as características dos agentes participantes desses eventos e como as combinações entre esses elementos influenciaram no processo estratégico;

- Sistematizar as descobertas empíricas e teóricas tendo em vista a elaboração do esquema analítico;

- Aplicar o esquema a ser proposto na análise de dois eventos ocorridos na EACH;

- Analisar, fundamentado no esquema, práticas utilizadas pelos gestores durante o processo;

- Analisar, fundamentado no esquema, processos e modelos organizacionais em uso na universidade. 


\subsection{Questões de Pesquisa}

A partir desses objetivos podem-se destacar as questões de pesquisa:

a) Como pode ser caracterizado o processo de formulação e implementação da estratégia, ocorrido quando da criação e implantação da EACH?

b) Quem são os agentes que participam diretamente do processo estratégico e quais elementos do contexto histórico, social e cultural e dos sistemas organizacionais são mobilizados pela ação destes agentes, identificados a partir da análise dos dados da pesquisa?

c) Como os agentes organizacionais agem e interagem e como surgem e se desenvolvem as ações estratégicas a partir da combinação desses três elementos (agentes, contexto e sistemas organizacionais)?

d) É possível definir alguns comportamentos dos gestores universitários que colaboram com o processo ou, ao contrário, dificultam a sua condução?

e) Como pode ser interpretado o processo à luz dos modelos e abordagens utilizados na análise da organização universidade e que conformidades e contradições podem ser detectadas?

f) A experiência da EACH poderá colaborar com a criação e institucionalização de novas práticas administrativas e pedagógicas na USP e na universidade pública brasileira contribuindo para as tentativas de solução de suas crises? Quais proposições para a USP as conclusões da tese poderão sugerir?

\subsection{Justificativa: Relevância e Ineditismo}

A tese se propõe a contribuir com os estudos organizacionais sobre estratégia nas perspectivas processual e prática, por meio de um melhor entendimento de como ocorreu o processo de formulação e implementação do projeto de criação de uma nova unidade, em uma universidade pública brasileira. O avanço teórico e prático no campo da análise da organização universitária e a importância dos resultados dos projetos desenvolvidos na universidade para a sociedade sintetizam a relevância da pesquisa. 
Estratégia e mudança são temas recorrentes na prática e na teoria das organizações. O estudo integrado das duas é demonstrado pelo número crescente de pesquisadores interessados em saber sobre o processo que resulta em mudança, em especial, sobre como as estratégias organizacionais são formuladas e implementadas (VAN DE VEN, 1992).

O processo foca como gestores/agentes podem influenciar continuamente a qualidade da posição de uma organização por meio de processos apropriados de tomada de decisão e do uso de sistemas administrativos.

Apesar da centralidade que a temática da estratégia assume no campo universitário, ainda são poucos os estudos interessados em explicar como ela surge e se desenvolve nas universidades brasileiras (HARDY; FACHIN, 2000) e quais as lições que podem ser apreendidas de experiências realizadas.

As universidades são instituições que reproduzem regras do sistema social, mas também possuem o importante papel de interpretá-las, modificá-las e de contribuir para a criação de novas. Isso ocorre a partir de ações estratégicas, como a criação de novas formas de produção e difusão do conhecimento, a elaboração de novos cursos, a implementação de inovações curriculares, o desenvolvimento de formas específicas de gestão, por exemplo, e que terminam por produzir mudanças na própria sociedade, de forma mais específica, em um determinado setor social. Parte-se do pressuposto de que possuem para tanto autonomia relativa diretamente relacionada com a sua história, às experiências vividas e à capacidade acumulada de seus indivíduos e grupos. São organizações especiais, complexas, pluralísticas, nas quais os processos organizacionais devem ser aplicados de forma diferenciada de outras organizações e, portanto, devem ser analisados levando-se em consideração essa diferença.

Na universidade, a dicotomia do acadêmico e do administrativo tem contribuído para uma visão distorcida da administração. No nível micro de análise é quase sempre vista apenas como uma técnica restrita à burocracia universitária, enquanto no nível macro é associada a uma perspectiva gerencialista de intervenção política e econômica sobre os atores e organizações educacionais. Ao se buscar compreender melhor como ocorre um processo estratégico em uma universidade pública espera-se também contribuir para superar essa dicotomia provando a interconexão existente e a influência positiva que pode surgir a partir dessa combinação. 
Passados mais de setenta e cinco anos desde sua fundação, a USP consolidou-se como um marco não apenas para São Paulo, mas para o Brasil e para o mundo. Com mais de oitenta mil alunos, 234 cursos de graduação e várias unidades na capital e no interior, apresenta estrutura e funcionamento organizacional peculiar.

A USP é uma organização "com estrutura constitutiva extremamente complexa, quer pelo seu tamanho, quer pelos seus objetivos, quer pelas suas unidades constitutivas e, por estes mesmos motivos, de operação extremamente heterogênea" (ALMEIDA, 2004, p. 17).

Sua influência no setor universitário brasileiro a eleva a uma posição de modelo para as demais universidades. Conhecer o processo de criação de sua nova unidade, na qual várias inovações estão sendo implementadas, poderá produzir novos conhecimentos organizacionais e educacionais para o setor e prováveis benefícios para a sociedade.

Outro aspecto relevante está relacionado ao fato de que as conclusões e proposições sugeridas poderão auxiliar os agentes a lidar de forma mais efetiva com a formulação e implementação de projetos na universidade. Pois, talvez, o propagado fracasso das estratégias em organizações complexas decorra, entre outros fatores, das limitações na elaboração de uma análise mais abrangente da situação que possa contemplar o problema em sua complexidade.

O ineditismo da tese, em uma visão mais geral, tem a ver com a complexidade da temática. Em razão disso, Van de Ven (1992) salienta que poucos estudos sobre formulação e implementação de estratégias foram realizados. Dificuldades de acesso às organizações e aos gestores e a possibilidade limitada de observar diretamente as ações típicas de uma organização tornam difícil ao pesquisador penetrar na dinâmica da organização em análise.

Além disso, em função da diversidade de fatores envolvidos no estudo do fenômeno, existe a intenção de utilizar-se na pesquisa dos avanços teóricos não apenas da área organizacional, mas de ciências e teorias capazes de ampliar o escopo das explicações científicas.

No campo da sociologia, como exemplo, a Teoria da Estruturação de Anthony Giddens (2003) e a sociologia da transformação social de Sztompka (2005) têm procurado estabelecer 
a conexão entre estrutura e ação, abrindo espaço para perspectivas menos deterministas de definição estratégica, mas também não supervalorizando a ação voluntária dos atores isoladamente. Estrutura e ação tomam parte de forma indissociada no processo, situando a estratégia na abordagem da gestão como prática social.

Nos estudos organizacionais, as perspectivas como processo (VAN DE VEN, 1992; VAN DE VEN; POOLE, 1995) e como prática (WHITINGTON, 2003; JARZABKOVSKI; WILSON 2002) incorporam essas teorias à análise organizacional e descortinam novas possibilidades de avanços nas pesquisas.

O ineditismo, em uma visão mais específica, configura-se quando, a partir do estudo dessa complexidade teórica e prática, espera-se elaborar um esquema analítico que possa funcionar como um guia orientador ao pesquisador e ao estrategista em sua busca e compreensão das informações que sirvam para enfrentar a complexidade das situações encontradas. Deverá constituir-se, tanto como meio de leitura, quanto possível instrumento de ação e fornecerá hipóteses para aceder aos conhecimentos pertinentes, assimilar novos dados, interpretar uma situação, inferir novas informações, assim como possibilitar constatações.

\subsection{Definições Teóricas da Pesquisa}

A seguir são expostas as definições teóricas dos principais tópicos desenvolvidos na tese.

a) Esquema analítico: Um esquema é uma estrutura composta de dimensões entre as quais existem relações. Ela comporta variáveis que ainda não estão particularizadas para uma utilização em um contexto específico. O esquema permanece impreciso quanto a seu modo de emprego e à consideração das restrições de ordem. Ele contém regras gerais que não são acompanhadas de instruções ou de conselhos que permitam sua operacionalização efetiva.

b) Contexto: Entendendo o contexto como um delineador do "campo epistemológico" para os tomadores de decisão, Whitaker (1998, p. 111) define contexto "como a interação da tradição cultural, das experiências passadas e das circunstâncias em desenvolvimento com o conjunto das estruturas institucionais existentes e os quadros 
cognitivos e imaginários que os envolvidos trazem consigo e rotineiramente concretizam nas situações de ação".

c) Estrutura (na Teoria da Estruturação): “O conjunto de regras e recursos implicados, de modo recursivo, na reprodução social; as características institucionalizadas de sistemas sociais têm propriedades estruturais no sentido de que as relações estão estabilizadas através do tempo e do espaço" (GIDDENS, 2003, p. XXXV).

d) Teoria da Estruturação: Teoria concebida por Anthony Giddens para a análise da ação humana nas organizações, explorando a necessidade de se entender o vínculo existente entre o comportamento individual e as estruturas sociais. Como a ação humana produz e reproduz ao mesmo tempo determinadas estruturas sociais. O autor em sua teoria busca uma forma de evitar a dicotomia entre subjetivismo e objetivismo, determinismo e voluntarismo. Os agentes humanos não respondem mecanicamente às estruturas sociais, mas utilizam essas estruturas para fundamentar suas ações.

e) A ação humana nas organizações é definida a partir de "um processo de construção social que ocorre ao longo do tempo e do espaço, constituindo-se num conjunto de práticas complexas e distintas que depende, entre outros fatores, da maneira particular como cada ator organizacional apreende papéis a eles designados, da relação com outras pessoas, bem como dos contextos culturais nos quais estão inseridos" (Whitley; Stewart, apud JUNQUILLO, 2005, p. 1).

f) Cultura organizacional: Conjunto de crenças e valores que definem a condução de uma organização (PETTIGREW, 1989). Essa perspectiva integradora é confrontada com uma perspectiva de diferenciação e de fragmentação: "A cultura organizacional não é unitária, é uma conexão (nexus), onde se cruzam influências ambientais, criando um conjunto de subculturas que se sobrepõe e se abriga dentro das fronteiras permeáveis da instituição" (MARTIN e FROST, 2001, p. 227).

g) Processo Estratégico: Por que e como uma estratégia é elaborada e são desenvolvidas decisões e ações para a sua implementação. Para Mintzberg (2000), a maneira como uma organização desenvolve ou formula estratégias e o modo como são validadas e implementadas.

h) Sistemas organizacionais: referem-se à estrutura organizacional, planejamento, controle, incentivos, gestão de recursos humanos e o sistema de valores da organização - cultura (CHAKRAVARTHY e DOZ, 1992). Na tese, os sistemas organizacionais são mobilizados durante a ação dos agentes em um dado contexto. 
Além dos sistemas citados pelos autores, deve-se acrescentar a estrutura não-formal, as subculturas, a tecnologia, a política e os processos decisórios.

\subsection{Estrutura da Tese}

Este primeiro capítulo define o objeto da pesquisa, a universidade pública, destacando sua complexidade e especificidade organizacional. Para contextualizá-la, identifica as características dos modelos acadêmicos e organizacionais predominantes e destaca as pressões contemporâneas por mudança em sua estrutura e funcionamento o que tem exigido a criação de novas estratégias. Destaca, porém, o problema da dissociação entre as intenções estratégicas e as ações implementadas e a dificuldade em explicar como ocorrem os processos estratégicos em razão de sua complexidade e especificidade, o que pode resultar em fracasso na implementação de projetos estratégicos. Disso resultam o problema de pesquisa, os objetivos geral e específicos e as questões de pesquisa. Concluindo o capítulo, procura-se destacar a relevância, o ineditismo e os principais conceitos de fundamentação da tese.

O segundo capítulo apresenta os fundamentos teóricos que dão sustentação aos principais pressupostos da pesquisa, que juntamente com a pesquisa empírica realizada na $\mathrm{EACH}$, possibilitarão a elaboração do esquema analítico. O capítulo é dividido em três seções. Ao analisar e buscar compreender como ocorrem os processos no interior da organização universitária é necessário procurar responder que organização é esta, quais suas características principais que a configuram como uma instituição particular, seus principais sistemas administrativos e quais os principais modelos organizacionais utilizados para explicar o seu funcionamento, tarefa que corresponde à primeira seção. Em seguida, abordam-se as teorias da estruturação e a da transformação social. A terceira seção destaca as diferentes visões sobre o processo estratégico, alguns conceitos e tipologias. Também aborda as teorias sobre processo de Van de Ven e Poole e conclui com uma breve referência sobre estratégia em organizações educacionais.

A metodologia apresenta a fundamentação paradigmática dos estudos organizacionais, destacando a abordagem interpretativa e sua integração à análise estratégica numa perspectiva dialética. São descritos os procedimentos metodológicos que embasaram a coleta e a análise dos dados empíricos e apresentado o modelo orientador da pesquisa. 
O capítulo quatro contempla o detalhamento da elaboração do esquema analítico construído a partir da fundamentação teórica e da observação da experiência da $\mathrm{EACH}$, seus principais elementos, definições, dinâmica de funcionamento e operacionalização em pesquisas.

O quinto capítulo demonstra a aplicação do esquema analítico proposto na análise de dois eventos do caso em estudo: o primeiro, a elaboração do projeto de criação da EACH e o segundo, a elaboração do projeto do primeiro curso de mestrado da $\mathrm{EACH}$.

No sexto e último capítulo são registradas as conclusões da tese a partir das questões de pesquisa, apresentadas proposições como contribuição para a USP e sinalizados caminhos para futuras pesquisas. 


\section{FUNDAMENTAÇÃO TEÓRICA}

O capítulo está dividido em três partes. Primeiramente, são apresentados alguns fatos marcantes sobre o contexto histórico, social e cultural da instituição universidade. De forma breve, são apresentados os modelos universitários que influenciaram os projetos de criação das universidades públicas brasileiras e suas características principais. Aborda-se a trajetória histórica da universidade brasileira a partir das mudanças ocorridas quando da implantação dos marcos institucionais que ocorreram em 1931, 1968 e 1996, e, de forma mais detalhada, se procura caracterizar o atual contexto social em que se insere a universidade, suas crises e contradições resultantes de pressões por mudanças.

Em seguida, são apresentadas características dos sistemas organizacionais da universidade pública no Brasil, relacionando-os com os principais modelos organizacionais de análise em uso desse tipo de organização. Também se procura caracterizar de forma sucinta os principais agentes universitários (gestores e grupos de professores) e que são os responsáveis pela formulação e implementação dos projetos e ações na universidade.

O objetivo, seguindo a concepção de estratégia como processo e como prática, é identificar e expor teoricamente análises críticas sobre o contexto da universidade no mundo e no Brasil, as características dos sistemas organizacionais e as formas de atuação dos agentes, encontrados na maior parte das publicações sobre esse tipo de organização.

Justifica-se essa ampla análise de modelos explicativos neste capítulo concordando com Van de Ven et al (2000, p. 50):

\footnotetext{
A especificação mais precisa de uma ampla gama de modelos de desenvolvimento é uma necessidade. Só com um repertório de modelos de longo e curto prazo, incorporando diferentes mecanismos explicativos que estaremos em uma posição para abordar a complexidade dos processos estratégicos.
}

A segunda parte do capítulo apresenta as teorias sociológicas de fundamentação do esquema analítico. Finaliza-se o capítulo com abordagens teóricas sobre estratégia organizacional. 


\subsection{Universidade Moderna: Contexto, Organização e Agentes}

O marco do surgimento da universidade moderna é a organização da Universidade de Berlim, em 1808, fundamentada nos princípios defendidos por Humbolt em seu texto "Sobre a organização interna e externa das instituições científicas superiores em Berlim”. Esses princípios embasaram o projeto e o modelo de universidade moderna e até hoje são considerados como relevantes, permanecendo como uma espécie de ideal a ser alcançado.

Os princípios essenciais postulados por Humbolt são os seguintes: a formação por meio da pesquisa; "a unidade entre o ensino e pesquisa; a interdisciplinaridade; a autonomia e a liberdade da administração da instituição e da ciência que ela produz; a relação integrada, porém autônoma entre Estado e Universidade" (PEREIRA, 2009, p. 31). Para a realização deste ideal de universidade haveria necessidade de integração entre professores e alunos, um professor criador e um corpo discente integrado a este.

Essa idéia de uma instituição na qual seus membros estejam plenamente integrados e imbuídos de seus objetivos e fins levou Habermas a fazer o seguinte questionamento crítico:

[...] Não será já de si irrealista a premissa que pretende que uma estrutura inabarcável e incontrolável como o sistema universitário moderno deve estar perpassada e ser sustentada pela forma de pensar comum de todos os seus membros? (HABERMAS, 1993, p. 112).

Para Humbolt, segundo Habermas (1993), para além dessa integração entre pessoas e os objetivos da organização, a unidade na universidade se daria pela liga propiciada pela Filosofia entre as ciências da natureza e as do espírito.

Outro pressuposto do modelo humboltiano é o papel central das instituições científicas superiores não apenas no âmbito educacional, mas também na cúpula do sistema moral das nações. Sobre esse aspecto Habermas afirma: "O certo é que desde o princípio não ficou claro como iria conciliar-se a missão crítico-emancipatória com a abstinência política, que era afinal o preço que a universidade tinha de pagar pela organização estatal da sua liberdade" (HABERMAS, 1993, p.119). 
No Brasil, além da concepção idealista especificada acima, a universidade foi influenciada também por uma perspectiva funcionalista que via outros propósitos para a universidade e outra forma de vinculá-la à sociedade e ao governo:

\footnotetext{
Via a missão da universidade voltada para as necessidades sociais, com a função de servir a nação e a finalidade de ser de utilidade coletiva, sociopolítica e socioeconômica. Nesta concepção, a universidade é tida principalmente como uma instituição instrumental de formação profissional e de formação política. É o modelo desenvolvido na França (modelo Napoleônico) e nos países socialistas. Suas normas são emanadas do exterior, sua autonomia é relativa e seu controle pelas forças de poder é preponderante (PEREIRA, 2009, p. 32).
}

Destaque-se que a preocupação da universidade napoleônica era com a estabilidade do Estado, e, para isso, centralizava as atividades de ensino e as direcionava para produzir as competências profissionais e administrativas necessárias a essa estabilidade.

O modelo Humboltiano de universidade, as críticas de Habermas e o modelo Napoleônico apresentam outros aspectos, porém, os acima especificados estão no cerne dos debates que permanecem até hoje no funcionamento das universidades, como as temáticas da autonomia administrativa e pedagógica e da interferência governamental, por exemplo.

Para situar essas temáticas na realidade brasileira, empreende-se uma breve retrospectiva histórica da universidade no Brasil a partir das reformas de 1931 e 1968 e da Lei de Diretrizes e Bases da Educação Nacional de 1996, marcos institucionais no setor.

O Decreto $\mathrm{n}^{\mathrm{o}}$ 19.851, de 11 de abril de 1931, instituiu o Estatuto das Universidades Brasileiras, definindo que o ensino superior "obedecerá, de preferência, ao sistema universitário", podendo ainda ser ministrado por institutos isolados. Define como fins do ensino universitário elevar o nível da cultura geral, estimular a investigação científica em quaisquer domínios; "habilitar ao exercício de atividades que requerem preparo técnico e científico superior; enfim concorrer pela educação do indivíduo e da coletividade (...) para a grandeza da Nação e para o aperfeiçoamento da Humanidade" (Art.1 ${ }^{\circ}$ ). Segundo o mencionado Decreto, a organização das universidades "atenderá primordialmente ao critério dos reclamos e necessidades do país [...] e será orientada pelos fatores nacionais de ordem psíquica, social e econômica" (Art.2º (Anteprojeto de Lei da Educação Superior, 2005, p. 4). 
Em um contexto de forte centralismo estatal, a norma legal afirma que "as universidades gozarão de personalidade jurídica e de autonomia administrativa, didática e disciplinar" nos limites do Decreto (Art. $9^{\circ}$ ), admitindo-se "ampliar pela incorporação de novos Institutos,

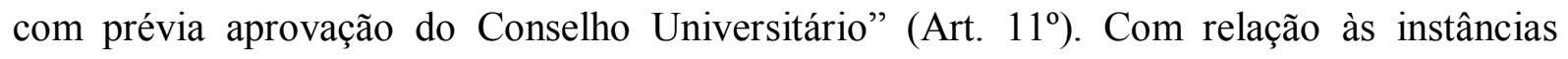
decisórias, as universidades seriam administradas: "por um Reitor e por um Conselho Universitário, sendo que o Reitor, nas universidades federais e estaduais, será de nomeação dos respectivos governos, devendo a escolha recair em nome de listas tríplices, votadas pelos respectivos Conselhos Universitários" (Art. 17º). Foi prevista uma Assembléia Universitária “constituída pelo conjunto dos professores de todos os Institutos Universitários" (Art. 24). Também "a "vida social universitária foi organizada prevendo associações de docentes (Sociedade de Professores Universitários) e discentes (Diretório Central dos Estudantes), cujos estatutos seriam aprovados pelo Conselho Universitário" (Anteprojeto de Lei da Educação Superior, 2005, p. 5).

Nesse primeiro período da universidade no Brasil, predominam, estruturalmente, na maioria das instituições, os cursos e os professores catedráticos. A base da organização acadêmica das universidades era o curso, que tinha o seu currículo dividido em matérias, cada qual com um catedrático. Por exemplo, a matéria biologia teria um catedrático em cada unidade da universidade em que fosse ministrada. Além do mais, para alterar o currículo era precisa alterar as cátedras, processo quase impossível de realizar-se de dentro para fora.

Entre as principais novidades da reforma universitária de 1968 está sua inspiração em um modelo de organização racional do trabalho, inspirado no taylorismo, evidenciado em duas diretrizes principais: a) na eliminação da duplicação de meios para fins idênticos ou equivalentes; e b) na separação entre as atividades de concepção e de execução (CUNHA, 1999).

Em razão dessas diretrizes, o regime de cátedras foi extinto pela Lei 5.540, de agosto de 1968, sendo substituído pelo regime departamental e pela divisão dos cursos de graduação entre o ciclo básico e o ciclo profissional (CUNHA, 1999). Foram criadas duas novas instâncias na estrutura universitária: a coordenação e o colegiado de curso, formado por representantes dos departamentos que ministram disciplinas no curso. Até hoje, a grande maioria das universidades públicas brasileiras segue esse padrão isomórfico. Uma tentativa de ampliar a 
flexibilidade do sistema foi dada, em linhas gerais, pela Lei de Diretrizes e Bases da Educação Nacional (LDB, 9.394/96).

Na LDB (UFU, 1998. p. 32-33), as universidades "são instituições pluridisciplinares, de formação dos quadros profissionais de nível superior, de pesquisa, de extensão e de domínio e cultivo do saber humano" (Art. 52 $)$. A Lei estabelece que para garantir a autonomia didáticocientífica das universidades, caberá aos seus colegiados de ensino e pesquisa decidir, dentro dos recursos orçamentários disponíveis, sobre: "I. criação, expansão, modificação e extinção de cursos; II. Ampliação e diminuição de vagas; III. Elaboração de programas de cursos; IV. Programação das pesquisas e das atividades de extensão; V. Contratação e dispensa de professores; VI. Planos de carreira docente" (Art. 53º.

Estruturalmente, a LDB/96 possibilitou às universidades maior flexibilização, podendo estas experimentar formas diversas de organização (CUNHA, 1999). Essas inovações podem ocorrer em toda a organização ou em apenas uma unidade da organização. A partir da promulgação da LDB/96, algumas instituições promoveram mudanças em sua forma de seleção de ingresso dos alunos, criando, por exemplo, os sistemas de ingresso seriado (UNB, UFSM e UEPA). Poucas optaram por mudanças nas estruturas organizacionais e no funcionamento dos órgãos deliberativos, como os colegiados (UFMG). Após quatorze anos de implantação da LDB, a flexibilidade organizacional da universidade brasileira ainda está no seu início, apesar do movimento mundial por mudanças nas universidades.

Como de dentro os movimentos inovadores são quase imperceptíveis, o estado centralista continua formulando normas com a justificativa de poder criar uma padronização organizacional e qualitativa das instituições. É o caso da primazia que a pesquisa continua ocupando em relação ao ensino nas universidades, o que conduz os indicadores de avaliação dos docentes a pautarem-se fundamentalmente na produção acadêmica. Postura legitimada internamente pelas universidades e externamente na CAPES (SEVERINO, 2008, p. 11).

O ensino superior no mundo, em especial, as organizações que adotam o modelo de universidade, vem sendo atingido por mudanças contextuais há mais de três décadas. Essas mudanças podem ser agrupadas para análise em duas categorias: a primeira refere-se às mudanças tecnológicas, econômicas e sociais que estão ocorrendo no ambiente geral, e a 
segunda, no ambiente específico, às mudanças nas formas de produção e difusão do conhecimento, assim como, no seu próprio significado social, que trazem reflexos para suas atividades acadêmicas e administrativas.

Castells (2006) destaca o aparecimento de uma revolução tecnológica concentrada nas tecnologias da informação, sendo esta responsável por uma 'remodelação' da base material da sociedade e de sua própria geopolítica. No campo econômico, algumas modificações podem ser destacadas, como: a profunda reestruturação do capitalismo por meio da integração global dos mercados financeiros, o aumento da concorrência econômica global, a descentralização das empresas e sua organização em redes tanto internamente quanto em relação com outras empresas e a diversificação da força do trabalho.

Socialmente, houve uma redefinição fundamental da relação entre mulheres, homens, crianças e, consequentemente da família, sexualidade e personalidade. A consciência ambiental permeia as instituições da sociedade influenciando o funcionamento das empresas, os sistemas políticos passam por crise de legitimidade e os movimentos sociais tendem a ser fragmentados. Assumem posição central as identidades coletivas e individuais, conforme afirma Castells (2006, p. 41):

Em um mundo de fluxos globais de riqueza, poder e imagens, a busca da identidade, coletiva ou individual, atribuída ou construída, torna-se a fonte básica de significado social. (...) a identidade está se tornando a principal fonte de significado em um período histórico caracterizado pela ampla desestruturação das organizações e deslegitimação das instituições.

Esse cenário de transição, com suas ambigüidades e contradições, trouxe para as organizações significativas mudanças no seu funcionamento (DE MASI, 2000).

No caso particular do ensino superior, o ambiente específico sofreu mudanças institucionais e operacionais significativas, provocando efeitos no significado social da universidade, em sua estrutura e dinâmica internas, assim como, no tipo de relação estabelecida com os agentes sociais e econômicos de quem, de certa forma, possui algum grau de dependência. Para Zabalza (2004), a crise (ou as crises) que a universidade vem enfrentando deriva dessas mudanças, algumas já consolidadas por normas legais e outras ainda em processo. 
O sociólogo Boaventura Santos (1997) caracterizou os tipos de crises que vem atingindo a universidade, em uma perspectiva macrossocial, denominando-as como crises de hegemonia, legitimidade e institucional. $\mathrm{O}$ que as diferenciam são as contradições que as constituem. Assim, a crise de hegemonia está relacionada com a exclusividade dos conhecimentos que a universidade cria e difunde e compreende as dicotomias entre alta cultura e cultura popular, educação e trabalho e teoria e prática. Analisa também as questões da produtividade na universidade e a relação desta com a sociedade.

A crise de legitimidade enfoca "o espectro social dos destinatários dos conhecimentos produzidos e, portanto, a democraticidade da transmissão destes” (SANTOS, 1997, p. 192). Para o autor, “[...] quando a procura por educação deixa de ser uma reivindicação utópica e passa a ser uma aspiração socialmente legitimada, a universidade só pode legitimar-se, satisfazendo-a" (Ibid., p. 211).

Na crise institucional estão presentes a perda, ou a ameaça de perda, de valores fundamentais para a universidade, como a autonomia financeira e acadêmica, a avaliação de suas próprias ações e a constituição de sua própria estrutura organizacional. O autor situa essa crise no quadro das interferências normativas imprimidas pelos governos liberais na Europa e nos países em desenvolvimento.

Também ao analisar a mudança na universidade no mundo, Zabalza (2004), em uma perspectiva mais organizacional, procura destacar algumas características gerais das organizações, mas que ao serem transplantadas para a universidade apresentam diferenciações importantes.

Para o autor, como primeira característica, a universidade é um sistema aberto, ou seja, é influenciada pelo ambiente, com o qual está em permanente processo de interação, mas não em total dependência deste, pois como instituição social deve ser capaz de influenciá-lo, agindo com responsabilidade social.

O segundo aspecto está relacionado com mudanças na relação entre os agentes e a organização universitária. Por serem valores que mais marcaram a identidade da universidade ao longo dos anos, as mudanças ocorridas nesse princípio têm influência em várias dimensões 
da organização, como a cultura, a estratégia e a estrutura organizacional. As características que surgiram nesse processo de mudança, na visão do autor, são as seguintes:

\begin{abstract}
A incorporação da filosofia da democracia, a nova ética da praticidade, a busca de estratégias mais eficazes para o desenvolvimento pessoal, os novos modos de colegialidade, as novas formas de relação interpessoal, os novos processos de criação de "filiais" e fobias entre indivíduos e grupos oriundos da disseminação dos órgãos de poder e de tomada de decisões (ZABALZA, 2004, p. 68).
\end{abstract}

O terceiro aspecto foca o poder diferencial que os membros da universidade possuem. Isso se deve aos diferentes papéis que exercem na organização e suas diferentes competências e possibilidades de participação. Essa característica pode ser positiva ou negativa dependendo da situação. Se por um lado permite autonomia e liberdade aos membros, questão essencial nos processos educativos, por outro, a organização fica à mercê do profissionalismo de seus membros. Processos que requerem alguma sinergia, como a implementação de estratégicas, podem ser limitados pela orientação extremamente individualista e muitas vezes pouco profissional dos membros da instituição.

A partir da análise dessas crises, contradições e características particulares da universidade no mundo, Santos (1997) apresenta questões gerais que podem ser sintetizadas dessa maneira: como ampliar os espaços de atuação da universidade permitindo a inclusão de um número cada vez maior e diversificado de pessoas sem perda da qualidade? Como modernizar a gestão da organização mantendo, porém, fundamentos de sua cultura como a autonomia, a democracia e a liberdade de decisão de seus membros?

São questões que se acredita que a tese pode contribuir para responder já que o processo de inovação da EACH é uma tentativa de atuar sobre elas, e este estudo uma busca por respostas fundamentadas na teoria e na reflexão dos agentes a partir de suas experiências, avanços e contradições.

Os aspectos contextuais destacados relacionam-se com uma organização complexa e única sendo necessário, na continuidade do estudo, entender melhor o funcionamento de seus sistemas organizacionais e algumas características de seus agentes. 
A especificidade da organização universitária é demonstrada em suas características estruturais e processuais. Enquanto organização ela poderia ser caracterizada, numa perspectiva funcionalista, como:

\begin{abstract}
Uma coletividade com uma fronteira relativamente identificável, uma ordem normativa (regras), níveis de autoridade (hierarquia), sistemas de comunicação e sistemas de coordenação dos membros (procedimentos); essa coletividade existe em uma base relativamente contínua, está inserida em um ambiente e toma parte de atividades que normalmente se encontram relacionadas a um conjunto de metas; as atividades acarretam consequências para os membros da organização, para a própria organização e para a sociedade (HALL, 2004, p. 30).
\end{abstract}

Diversos autores têm estudado a organização universidade e reconhecem a sua complexidade (ETZIONI, 1974) e o fato de estar inserida em um ambiente complexo (MINTZBERG, 2006). O objetivo a seguir é apresentar algumas das especificidades dos sistemas organizacionais que caracterizam uma universidade na atualidade, e que, segundo os modelos de análise estratégica estudados, exercem forte influência na sua formulação e implementação (PETTIGREW, 1987; HREBINIAK, 2006).

São destacados as dimensões e os processos mais encontrados nas abordagens iniciais da pesquisa na EACH e relacionados com a temática da tese, como a estrutura de poder organizacional, a cultura, a liderança e os processos de tomada de decisão, o que não significa que somente estes elementos participem como regras e recursos mobilizados na ação dos agentes nos processos estratégicos em universidades.

Existem várias conceituações sobre estrutura organizacional. Para Ranson, Hinings e Greenwood (1980), em uma abordagem de construção social, estrutura é vista como "um meio complexo de controle continuamente produzido e recriado na interação e, no entanto, molda essa interação" (apud HALL, 2004, p. 47). Em uma perspectiva mais funcionalista, Hall (2004, p. 47) destaca que as estruturas organizacionais realizam três funções básicas:

Primeiro e mais importante, as estruturas têm por finalidade produzir resultados organizacionais e atingir metas organizacionais - em outras palavras, ser eficazes. Segundo, as estruturas são criadas para minimizar ou, ao menos, regular a influência das variações individuais na organização. As estruturas são impostas para assegurar que os indivíduos se adaptem às exigências das organizações, e não o contrário. Terceiro, as estruturas são os cenários nos quais o poder é exercido (elas também fixam ou determinam que posições possuem o maior poder), as decisões são tomadas (o fluxo de informações para uma decisão é, em grande parte, determinado pela estrutura) e as atividades são realizadas (a estrutura é o espaço para as ações organizacionais). 
Qualquer pessoa que tenha tido uma experiência gerencial em uma universidade ou, mesmo, tenha nela desenvolvido uma atividade, encontrará dificuldades em associar essas funções básicas à realidade da organização. Primeiramente, algumas estruturas possuem uma finalidade muito mais política do que relacionada ao desempenho. É o caso, por exemplo, dos departamentos, em algumas instituições. Segundo, as atividades de uma universidade muitas vezes são feitas para atender interesses específicos, não diretamente relacionados aos objetivos da organização, mas, por exemplo, de um grupo acadêmico ou profissional. Terceiro, o exercício do poder e a tomada de decisão nem sempre estão diretamente relacionados com a estrutura formal, mas com uma estrutura não-formal e, até mesmo, informal. (LIMA, 2008).

Em razão dessa dificuldade em ajustar a realidade da organização universitária com determinados conceitos da teoria organizacional há necessidade de empreender buscas mais específicas. Mintzberg (2006) categorizou cinco configurações para organizações eficazes: estrutura simples, burocracia mecanizada, burocracia profissional, forma divisionalizada e adhocracia. Nesta classificação, as universidades foram identificadas como uma burocracia profissional, apesar do próprio autor reconhecer serem as organizações reais extremamente complexas, muito além do que qualquer uma dessas configurações possa representar.

No modelo de burocracia profissional o principal mecanismo de coordenação é a padronização de habilidades; a palavra-chave da organização é o núcleo operacional; os principais parâmetros de design são o treinamento, especialização horizontal das tarefas, descentralização vertical e horizontal; e os fatores situacionais característicos são o ambiente complexo e estável e o sistema técnico não regulado e sofisticado. Na burocracia profissional "tendo o controle sobre o seu próprio trabalho o profissional age independentemente de seus colegas, mas diretamente com os clientes que serve" (MINTZBERG, 2006, p. 213).

Outra característica da burocracia profissional é o caráter 'democrático' de sua estrutura administrativa. "Não apenas os profissionais controlam o seu próprio trabalho, mas também procuram o controle coletivo das decisões administrativas que os afetam” (MINTZBERG, 2006, p. 220). Muitas dessas decisões possuem implicações permanentes para o futuro da organização. 
Os administradores da hierarquia profissional encontrados na universidade, como os reitores e diretores das unidades, possuem, em tese, menos poder se comparados aos administradores da burocracia empresarial, por exemplo. Trata-se de tese polêmica e que precisa ser analisada no contexto de cada organização. Para Mintzberg (2006, p. 222), “o administrador profissional pode exercer uma série de papéis que lhe proporciona considerável poder indireto na estrutura".

Por exemplo, o papel que reitores e diretores desempenham na fronteira da organização entre os profissionais internos e as partes externas interessadas - governos, empresas, associações profissionais, comunidades, e assim por diante. A possibilidade de influenciar novas leituras dos stakeholders sobre a realidade, de comunicar planos e projetos internos visando obter legitimidade e de inserir a organização nos principais debates sociais são alguns exemplos do poder de agência desses profissionais. O papel do gestor universitário será mais abordado no item sobre poder e liderança.

Para finalizar a abordagem de Mintzberg sobre burocracia profissional, três assertivas elaboradas pelo autor sobre estratégia merecem atenção e são apresentadas abaixo:

1) A noção de estratégia - um padrão único e integrado de decisões comuns para toda a organização - perde muito de seu significado na burocracia profissional;

2) As estratégias da burocracia profissional são, largamente e não totalmente, aquelas dos profissionais individuais que trabalham na organização, bem como as das associações profissionais que atuam externamente;

3) As estratégias próprias da burocracia profissional representam o efeito cumulativo dos projetos ou das 'iniciativas' estratégicas que seus membros estão em condições de convencer sua implementação (MINTZBERG, 2006, p. 224-225, grifo nosso).

Essa terceira assertiva determina, por um lado, a intersecção entre estrutura, estratégia e o ‘jogo político' no qual os gestores e os demais membros estão permanentemente imersos na universidade. Saber manejá-la sem perder de vista o projeto estratégico da organização requer habilidades próprias dos gestores que esta tese procura identificar e compreender. Para tanto, amplia-se a análise da estrutura para a visualização da rede de fluxos regulamentados; dos sistemas de regras e comunicação formais e informais; dos sistemas de agrupamento de trabalho; e dos fluxos de processos decisórios. Ampliam-se também suas fronteiras, considerando "as relações externas estabelecidas como forma de compartilhar conhecimento, atingir objetivos em conjunto, obter recursos financeiros, materiais, virtuais, intangíveis e pessoais" (BULGACOV, 2007, p. 98). 
A terceira assertiva também destaca o espaço de experimentação de novos processos que surgem normalmente pela interação de pessoas em torno de problemas localizados e relacionados com uma determinada prática. O poder que um determinado grupo possa desenvolver está relacionado com a transformação dessas experiências em padrões institucionalizados ou regras de conduta, portanto, como prática aceita na organização.

Aproxima-se do modelo denominado de adhocrático, mais apropriado a um ambiente de mudança e inovação (HARDY; FACHIN, 2000). A grande diferença entre a burocracia profissional e a adhocracia é que nesta os profissionais lidam constantemente com problemas novos, que vão além das fronteiras conhecidas das disciplinas e das especialidades. Numa adhocracia, "os profissionais são reunidos em equipes multidisciplinares para que os recursos de diferentes especialidades possam ser agrupados com o objetivo de resolver os problemas existentes (Ibid., p. 34).

Antes de finalizar a dimensão estrutural, é importante destacar outra perspectiva de estrutura, menos prescritiva e normativa, centrada no plano da ação, ou seja, que se configura a partir da prática cotidiana. Podem ser denominadas como estruturas constituídas como regras nãoformais e regras informais (LIMA, 2008), ambas não possuindo caráter oficial, sendo seu uso restrito a um determinado grupo ou unidade organizacional.

As regras não-formais "são regras estruturadas ou semi-estruturadas, que podem tomar forma escrita e que tanto se podem orientar para a formulação de procedimentos operativos das regras formais, como para áreas de intervenção não formalmente regulamentadas ou legalmente consideradas" (LIMA, 2008, p. 53).

As regras informais são regras não-estruturadas. Lima (2008, p. 54) as caracteriza assim:

São regras não-estruturadas, ainda mais circunstanciais e podem não ser generalizadas a toda ou a amplos setores da organização. Têm um alcance mais limitado, podendo ser mesmo produzidas de forma ad hoc para a resolução de um problema específico.

São regras difíceis de serem identificadas e muitas vezes escondem interesses diversos aos objetivos da instituição. Outras vezes, correspondem ao inicio de um processo de construção de novas regras, daí o interesse da pesquisa em sua conceituação. 
O modelo adhocrático e as estruturas não-formais e informais configuram um contexto organizacional mais apropriado para o jogo político tão comum nas universidades. A seguir, é abordada a dimensão do poder na universidade pública e a especificidade que assume o papel das lideranças nos processos estratégicos educacionais.

O poder é central para a vida organizacional e sedimenta o processo de criação e implantação da estratégia. Para Clegg et al (2004, p. 26):

\begin{abstract}
A compreensão da estratégia exige comprometimento com o poder e a política. Isso nos ajuda a compreender melhor as decisões tomadas (e por quê), como se opera a não tomada de uma decisão, isto é, por meio da manutenção de tópicos fora da agenda, e também os meios pelos quais as elites dominantes exercem com sucesso controles hegemônicos sobre a criação de estratégias. Quais são as vozes ouvidas enquanto a estratégia é formulada? Que implicações têm, para o processo de formação, as vozes ouvidas e as silenciadas? Por exemplo, se a formulação for restrita à elite corporativa, poderá impulsionar a criatividade e a inovação? Ou tal processo servirá meramente para reproduzir os preconceitos e vieses das elites gerenciais?
\end{abstract}

Analisar uma organização do ponto de vista político é vê-la como um empreendimento constituído por redes de pessoas independentes e interdependentes, com interesses diferentes e comuns, as quais estão juntas por razões pessoais e profissionais. Nesse sentido, as organizações são compostas por coalizões e a construção de coalizões é uma importante dimensão de toda a vida da organização.

Autores como Baldigdre et al (1977), desenvolveram a tese de que as organizações universitárias podem ser estudadas como sistemas políticos em miniatura, pois apresentam a dinâmica de grupos de interesses e de conflitos semelhante aos que ocorrem nas organizações políticas, como a cidade e o Estado.

Na universidade, a prioridade é a participação e negociação, e seu processo decisório reflete muito mais um jogo político, no qual comissões e grupos emergentes funcionam e decidem a partir do conflito, negociações, coalizões e acordos, do que um processo no qual as decisões são tomadas por consenso, como em um colegiado (BALDRIDGE et al, 1977).

Zabalza (2004) salienta que outro aspecto desse processo político, que o autor sintetiza por meio do conceito de democracia, também trouxe para o interior da universidade práticas 
externas que acabaram por atingir um dos aspectos mais fundamentais da política científica e acadêmica que é o diálogo entre os pares. Assim se expressa o autor:

\begin{abstract}
O posicionamento ideológico e os postulados políticos vinculados às possíveis interpretações desses dois princípios introduziram na universidade uma nova definição da vida institucional, dos sistemas de divisão do poder e, de modo indireto, das formas de relação. Isso quer dizer que afinidades profissionais ou científicas que constituem os componentes básicos da relação interna da universidade sofreram um desequilíbrio e estão sujeitas a crises por causa das novas alianças ideológicas e políticas (ZABALZA, 2004, p. 74).
\end{abstract}

Apesar da existência de comissões e grupos emergentes, as grandes decisões estratégicas universitárias são tomadas formalmente nos órgãos colegiados. Dessa forma são construídos o Plano de Desenvolvimento Institucional (PDI), o Plano Político-Pedagógico (PPI), as reformas estatutárias e regimentais, as regras dos processos eleitorais, as normas dos concursos públicos, as formas de avaliação dos professores, por exemplo. É certo considerar que essas decisões são tomadas por consenso de maioria caracterizando um modelo colegiado, mas errado em supor que a política não esteja presente em todos os momentos desse processo.

Para a administração, a democracia apresenta-se como um desafio no qual a experiência e a reflexão na prática do gestor tornam-se parte permanente dos processos organizacionais. Entre os professores, a democracia diminui em tese o fosso entre os mais experientes e os novatos, mas não diminui a prática individualista e restritiva, segundo Zabalza (2004, p. 77), “cada um pode fazer o que melhor lhe convém”. Entre professores e alunos a democracia, em seus extremismos, tem causado situações conflituosas, prejudicando o processo acadêmico e administrativo.

Outro aspecto relacionado à temática é o poder adquirido pelos atores do contexto político, econômico e social em que a universidade está inserida, como os governos, políticos, empregadores, grupos sociais, entre outros, capazes de influenciar o funcionamento da universidade e afetar um de seus principais valores, a autonomia. Como exemplos podem ser destacados: propostas de reformas universitárias centralizadas, mudança na legislação por meio de portarias, interferência dos governos nos processos eleitorais para reitores, interesse de deputados e senadores na criação de novas universidades, pressão de prefeituras para instalação de pólos universitários, pressão da sociedade por políticas afirmativas, criação de novas vagas, abertura de cursos com maior empregabilidade, e assim por diante. 
Nesse contexto do formal e do informal, do interno e do externo, a gestão universitária tornou-se uma espécie de pêndulo no qual, paradoxalmente, os dirigentes buscam equilibrar as forças políticas muitas vezes opostas, mas que representam a atual realidade da universidade.

Forma-se um perfil compreensivo do líder político que mobiliza fontes de poder disponíveis via estratégias políticas para influenciar resultados ou decisões. Assim, por exemplo, adquirese a informação, gerenciam-se os especialistas, são encontrados os contatos com atores poderosos, controlado o acesso a recursos escassos, construídas as coalizões, cooptados ou neutralizados os oponentes etc. (PFEFFER; SALANCICK, 1974).

Outro aspecto importante na análise do poder na universidade é sua disfunção causada em conseqüência do excesso divisional da estrutura e de poderes paralelos que emergem no interior da organização (VIEIRA e VIEIRA, 2004). Essa característica faz surgir lideranças a cada momento, o que requer do gestor uma análise permanente dos movimentos internos da instituição. As características dessas lideranças são variáveis, podendo ir de um líder oposicionista cujo interesse é assumir o poder representado pela estrutura formal, derrotando quem está nele, até a de um ator organizacional com autoridade acadêmica e/ou técnica capaz de influenciar na interpretação do contexto e nos processos de decisão estratégica dos dirigentes da universidade.

Uma conceituação inicial de liderança que se próxima da realidade da organização universitária pode ser encontrada em Hall (2004), quando ele, fundamentado em Etzioni (1965), a define como:

\footnotetext{
Uma forma especial de poder [...] baseada nas qualidades pessoais do líder, para incentivar a concordância voluntária dos seguidores em uma ampla variedade de assuntos. Liderança se distingue do conceito de poder por acarretar influência, isto é, mudança de preferências, ao passo que o poder implica somente que as preferências dos subordinados são mantidas suspensas. Sob este ponto de vista, a liderança é atribuída ao indivíduo por seus seguidores, e não necessariamente por ocupar uma determinada posição hierárquica (HALL, 2004, p.. 127).
}

Esse aspecto foca uma das questões centrais sobre o processo estratégico em universidades públicas: até que ponto os gestores universitários são capazes de influenciar o desenvolvimento da estratégia e, consequentemente, viabilizar a sua implementação segundo um dado projeto? 
Pesquisas demonstram que há diversas maneiras pelas quais líderes e outros indivíduos- chave podem influenciar organizações, "incluindo a conformação de pensamentos, sentimentos, percepções e ações de pessoas dentro e fora das organizações, e tomando decisões que afetam a organização" (Mowday; Sutton, apud CLEGG et al, 2004, p. 56).

De forma mais específica ao tema da tese, Clegg et al (2004) afirmam que a compreensão do processo estratégico exige relacioná-lo com o poder e a política, ou como as decisões são tomadas e quem participa desse processo.

Pesquisadores educacionais como Csillag (1997) salientam a relevância da estratégia adotada pela liderança como fundamental para o bom desempenho da escola. Um sistema de liderança está relacionado às ações que implicam o envolvimento pessoal da alta direção, "promoção de desempenho elevado, manutenção do clima da aprendizagem entre as pessoas, criação da estrutura organizacional e sistema gerencial e revisão periódica dos resultados" (TAKAHASHI e MACHADO-DA-SILVA, 2002, p. 5).

Outro aspecto central na opção teórica seguida nesta pesquisa é o que trata o papel do líder no fornecimento de explicações, legitimações e lógicas para as atividades organizacionais, no que Pfeffer (1981) denominou de administração simbólica (apud CLEGG et al, 2004). Para alguns autores essa é a principal diferença entre liderança e gestão. A liderança preocupa-se com o propósito e a identidade organizacional, além de promover ativamente valores que provêm significados compartilhados sobre a natureza da organização (BRYMAN, 2004). A preocupação dos líderes é que os membros da organização interpretem corretamente as mensagens transmitidas por eles. Obviamente, da qualidade e coerência das mensagens vai depender o grau de influência do líder na organização.

Nesta perspectiva, para alguns autores, os gestores universitários assumem uma posição estratégica. Para evitar a simples sujeição da universidade às orientações externas, é papel do gestor universitário defender a missão e os planos de renovação acadêmica da instituição contra pressões de órgãos externos, "que legislam de maneira homogênea para uma comunidade heterogênea, em certos casos contra os interesses da comunidade a que deve servir e prestar contas" (KRASILCHIK, 2008, p. 8). 
Internamente, para enfrentar o isolamento característico dos departamentos e professores, Hardy e Fachin (2000, p. 22),

asseveram que os líderes tendem a influenciar a escolha estratégica de acordo com suas habilidades e escolhas pessoais. [...] as percepções dos líderes determinam, em grande parte, os problemas que são vistos prioritários e as soluções cabíveis.

Nesse aspecto, a construção dessas mensagens requer dos líderes acadêmicos, permanente reflexão sobre os seus próprios esquemas de interpretação da realidade, pois serão os esquemas quem definirão os contornos desta realidade, seja em razão de suas prioridades ou de seu discurso. A liderança de uma organização educacional como a universidade é praticamente centrada nessas questões.

Esses aspectos citados acima salientam um pressuposto da tese que é a interdependência entre os processos administrativos e acadêmicos ma universidade. Busca-se verificar, no processo estratégico, se ou como os lideres universitários compreendem essa questão e como trabalham para assegurar um ambiente organizacional no qual esses dois processos se auto-influenciem.

Tese reforçada por Nóvoa, (1992, p.26) ao afirmar que a coesão e a qualidade de uma escola dependem em larga medida da existência "de uma liderança organizacional efetiva e reconhecida, que promova estratégias concertadas de atuação e estimule o empenho individual e coletivo na realização dos projetos de trabalho".

Glatter (1992, p. 147) destaca que:

Nunca consideramos a gestão como uma atividade puramente técnica, divorciada dos valores e objetivos educacionais. [...] A gestão escolar deve ser antes tomada como uma atividade que pode facilitar e estruturar a definição de objetivos e que pode igualmente dar-lhes expressão prática.

Alonso (1988) salienta que o diretor ocupa uma posição estratégica e que seus atos são relevantes na determinação do trabalho escolar. O gestor encontra-se em diversos tipos de pressões, muitas vezes ambíguas, entre as quais as pressões legais e as sociais, e a posição de liderança em que se encontra lhe possibilita atuar de forma ampla sobre a comunidade educativa. 
Essas particularidades e ambigüidades que cercam as lideranças universitárias e escolares podem influenciar os processos de tomada de decisão e o posicionamento das lideranças para outras perspectivas e originaram outro modelo organizacional na busca de entender o funcionamento da universidade, além dos modelos burocrático-profissional, adhocrático, político e colegial, detalhados anteriormente. De forma breve, a seguir, apresenta-se o modelo de anarquia organizada.

A noção de anarquia organizada, inventada por Cohen et al (1972) difere radicalmente de uma burocracia bem organizada, de uma organização coesa e coerente ou do processo consensual do modelo colegiado. É característica de uma organização na qual os recursos disponíveis permitem que as pessoas sigam em diferentes direções sem coordenação de uma autoridade central. Os líderes são relativamente fracos e as decisões são tomadas a partir da ação individual de cada membro ou de um grupo definido, sendo que as decisões são geradas por processos não-planejados e emergentes, uma vez que os objetivos organizacionais são ambíguos e a participação é fluida. Em tais circunstâncias fluidas, o reitor e outros líderes institucionais servem primariamente como catalisadores ou facilitadores de um processo contínuo. Eles não comandam, mas negociam; não planejam racionalmente, mas tentam aplicar aos problemas, soluções pré-existentes, ou seja, as decisões não são "feitas", mas elas “acontecem" (BALDRIDGE, 1983).

Cohen e March (apud BALDRIDGE, 1983, p. 8) descrevem o processo decisório em uma anarquia organizada:

\footnotetext{
Como conjunto de procedimentos através dos quais os participantes organizacionais chegam a uma interpretação do que eles estão fazendo e do que eles têm feito enquanto eles estão fazendo essa busca. Deste ponto de vista, uma organização é uma coleção de escolhas diante de problemas, de temas e sentimentos que procuram por decisões que precisam ser repensadas, de soluções que buscam temas que possam oferecer respostas, e gestores que buscam trabalho.
}

A liderança da anarquia organizada pode também assumir uma postura política, mas suas estratégias são diferenciadas do modelo político. Com vistas ao objetivo de exercer influência sobre outros tipos de organização os autores argumentam que os líderes devem:

Despender tempo, persistir, trocar status por substância, facilitar a participação de oponentes, sobrecarregar o sistema, fornecer 'latas de lixo' para atrair e desmontar os assuntos em debate, gerenciar simbolicamente, e interpretar a história, por exemplo, reescrevendo as atas de reuniões (HARDY; FACHIN, 2000, p. 172). 
Uma das características desse modelo é a participação fluida nos processos de decisão, "ou, se preferirmos uma fraca estruturação dos mesmos: é fácil entrar ou sair dos processos de decisão, de neles introduzir novas preocupações ou de inferir outras a partir deles" (FRIEDBERG, 1993, p. 73).

Apesar de muitas vezes, de forma apressada, as universidades serem consideradas instituições totalmente anárquicas, é difícil identificar uma estratégia no processo anárquico, mas pode este representar, em alguns eventos, uma fase do processo estratégico. Também, a participação fluida vai de encontro aos estabelecimentos de laços estruturais, mais apropriadas à existência de determinados grupos. Essas duas questões corroboram com as críticas de Friedberg (1993) caso se adote este modelo de forma ortodoxa, pois este parece tratar as decisões estudadas como excepcionais e os atores participantes como passivos em uma perspectiva descontextualizada.

Isto não impede de considerar que algumas organizações, e especialmente as universitárias, possuem algumas características de anarquias organizadas ou são sistemas frouxamente acoplados (loosely coupled systems), como mais tarde especificados por Weick (1976).

Essa fragmentação provocada pela ambigüidade e pela complexidade da organização universitária de alguma forma precisa ser contrabalançada por algum elemento integrador. A seguir, aborda-se a questão cultural.

Ao analisar a universidade e tentar identificar aspectos fundamentais de seu funcionamento, a dimensão estrutural da cultura é um dos fatores mais influentes. Porém, a visão de cultura organizacional entre os autores é bastante diversificada.

Schein (1984, p. 3-4) considera a cultura organizacional como

O modelo dos pressupostos básicos, que determinado grupo tem inventado, descoberto ou desenvolvido no processo de aprendizagem para lidar com os problemas de adaptação externa e integração interna. Uma vez que os pressupostos tenham funcionado bem o suficiente para serem considerados válidos, são ensinados aos demais membros da organização como a maneira correta para se perceber, se pensar e sentir-se em relação àqueles problemas. 
Claramente destaca-se a visão de processo, a cultura como construção no presente que precisa ser apreendida pelos atores de uma organização específica e que permite o atuar juntos no enfrentamento de problemas novos e recorrentes. Artefatos, valores e pressupostos básicos são os conceitos principais em sua abordagem.

Martin e Frost (2001) afirmam existir na literatura cultural três abordagens. A denominada pelos autores de perspectiva de integração acredita na existência de uma cultura unificada e forte para toda a organização. Os gerentes de nível superior teriam o poder de construir esse tipo de cultura, "articulando um conjunto de valores, reforçando-os depois, muitas e muitas vezes, por meio de políticas formais, normas informais, histórias, ritos e jargão (MARTIN e FROST, 2001, p. 223). Grande parte da literatura sobre o tema advoga essa possibilidade e a própria imagem de integração entre as unidades, destacada no modelo humboltiano de universidade visto anteriormente, reforça essa idéia.

A segunda perspectiva apresentada pelos autores, denominada de diferenciação, desafia empiricamente a idéia monolítica de que as organizações e as pessoas possuem valores e interpretações unitários. Os pesquisadores desta corrente envolvem-se então em penetrar profundamente na vida prática da organização. Estudam os conflitos, o que precisa de solução, o que envergonha e as ambivalências.

Pesquisas de diferenciação evidenciaram que as subculturas no interior de uma organização podem refletir e até ser parcialmente determinadas pelos grupos culturais da sociedade maior. É o caso do administrador-professor da universidade que primeiramente ajusta-se aos padrões legitimados da administração como profissão para, somente depois, se reconhecer como professor universitário. Assim, cultura na perspectiva de diferenciação pode ser vista como:

\footnotetext{
A cultura organizacional não é unitária, é uma conexão (nexus), onde se cruzam influências ambientais, criando um conjunto de subculturas que se sobrepõe e se abriga dentro das fronteiras permeáveis da instituição (MARTIN e FROST, 2001, p. 227).
}

Essas subculturas são conceituadas e classificadas na maioria dos estudos por meio de dimensões como categorias profissionais, gênero, identidades demográficas, distância do poder etc. (VASCONCELOS et al, 2004). 
Uma terceira perspectiva sobre cultura organizacional apresentada pelos autores é denominada de fragmentação e destaca alguns aspectos até então não considerados pelas duas outras perspectivas e uma concepção de mudança útil para a tese. Segundo esta perspectiva, as manifestações culturais são complexas e contém muitos elementos de contradição e confusão. O consenso ocorre nem mesmo entre subculturas, mas de forma transitória e específica sobre determinada questão, produzindo afinidades de curta duração.

Segundo Martin e Frost (2001, p. 234), na perspectiva de fragmentação "o poder é amplamente difundido por todos os níveis da hierarquia. A mudança é um fluxo contínuo e não interrupções intermitentes da estabilidade”. As três perspectivas apresentam, no caso da universidade, um quadro mais rico e real sobre a dimensão cultural do que uma única abordagem.

Essa perspectiva mais fenomenológica da cultura enfoca o que integra e diferencia as universidades entre si e entre as unidades e grupos de uma mesma universidade, cultura que vai sendo construída diariamente por seus membros em interação. Isso pode ser constatado por meio de algumas qualidades diferenciais que elas apresentam, tais como as caracterizadas por Zabalza (2004, p. 80):

\begin{abstract}
a) O conjunto de [valores], concepções e símbolos que caracterizam o modo específico de atuação de cada universidade e que acabam configurando uma identidade própria e distinta; b) os jogos relacionais que ocorrem em seu espaço interior e que geram conflitos e, simultaneamente, mudanças institucionais e; c) as idéias, os recursos e as práticas que, além de consolidarem em cada universidade, são tidos como modelos de atuação apropriados, isto é, servem como referência aos processos de qualificação e desenvolvimento institucional.
\end{abstract}

Em relação ao primeiro item da assertiva acima, deve-se ter como pressuposto o fato de que a identidade institucional é construída no tempo. São os dirigentes universitários os maestros dessa 'partitura'. São eles que dão o 'tom' da organização. Ao mesmo tempo, essa identidade só perdurará se for compartilhada. Para tanto, "é preciso dispor de espaços e mecanismos institucionais que possibilitem essa identificação com os objetivos, com a missão, com as proposições, com os estilos de trabalho, com as normas e assim por diante" (ZABALZA, 2004, p. 83).

O que está em questão é o conceito de identidade social. Uma espécie de padrão de comportamento, percepção e representação da realidade muito semelhante que são 
desenvolvidos por pessoas que trabalham, por exemplo, em uma mesma organização e que de forma constante estão interagindo. A identidade social não significa uniformidade de opiniões ou idéias, mas um meio importante de integração, diálogo e entendimento.

Outro conceito importante do ponto de vista cultural da organização universitária é o de “grupo de referência”. Segundo Motta e Vasconcelos (2006, p. 313), "é o conjunto de pessoas cujas opiniões e crenças são importantes para a formação de nossas próprias opiniões e valores".

Para o docente em uma universidade, existem vários grupos de referência. Uma análise diferente da usual, poderia destacar esse fato como enriquecedor para a universidade durante o processo de implementação da estratégia, pois, por exemplo, pode facilitar a inserção de um novo membro de uma unidade em outras instâncias, contribuindo, por exemplo, para o processo de legitimação dessa nova unidade.

Após essa visão dos principais sistemas organizacionais e de aspectos que caracterizam os principais agentes em uma universidade pública no Brasil, e mais de acordo com a abordagem interpretativa que se pretende construir na tese, podem-se adotar outras definições para organização do tipo universidade, contrapondo-se à de Hall (2004), inicialmente apresentada. A organização pode ser considerada como "uma entidade heterogênea, composta por diferentes grupos funcionais em busca de objetivos e promovendo interesses" (GREENWOOD; HININGS, 1996, p. 1024) ou, como "um fenômeno socialmente construído, produto não somente das ações humanas intencionais, mas também de suas interações culturais, políticas, cognitivas e simbólicas, além das conseqüências não intencionais" (CRUBELLATE, 2004, p. 60).

Ainda de forma mais radical, pode-se chegar a uma visão muito mais complexa e conflitual da organização universidade. Pois, como Freidberg (1993, p. 69) afirma:

\footnotetext{
Uma organização não é neste caso um conjunto de mecanismos ordenados e movidos só por uma racionalidade. Não é mais um conjunto natural cujas necessidades ou imperativos funcionais de sobrevivência e de adaptação assegurassem como que por milagre os ajustamentos necessários entre os elementos constitutivos. [...] A organização desencarnou-se, agora já não tem mais que um contexto de ação no qual se atam e se geram relações de cooperação, de trocas e de conflitos entre atores com interesses divergentes.
} 
Ao apresentar uma caracterização da universidade pública brasileira a partir dos contextos, dos sistemas organizacionais e dos modos de comportamento de seus principais agentes buscou-se ampliar a visão sobre a organização universitária normalmente apresentada por publicações, seja na área da administração, ou na área educacional.

Percebeu-se não ser possível enquadrá-la em modelos concebidos a partir de abordagens monoparadigmáticas e unifocalizadas. Ao se pretender captar como ocorre o processo de formulação/elaboração e implementação de uma estratégia em uma universidade pública, a construção do esquema analítico deverá considerar os principais aspectos dessa complexidade.

Para tanto, optou-se na continuidade da fundamentação teórica para a elaboração do esquema analítico por teorias e abordagens que considerem esses elementos de forma integrada e analisem o sentido que as práticas humanas vão adquirindo no decorrer de uma dada trajetória em tempo e lugar contextualizados. São abordagens em que gestão e estratégia são analisadas como prática social.

Desse modo, nas seções seguintes são apresentadas as teorias sociológicas da estruturação e da transformação social e três abordagens que analisam o processo estratégico.

\subsection{Teorias de Fundamentação da Gestão como Prática Social}

Para Michael Reed (1989), as perspectivas de análise da gestão predominantes na literatura organizacional não resolvem algumas questões centrais, dentre as quais é possível resumir: a) a não-contemplação, nos modelos de análise, de uma proposta que integre, numa mesma perspectiva, as idéias de contexto institucional, estrutura organizacional e comportamento gerencial; e b) a ênfase ora no determinismo das estruturas, ora na ação humana estratégica, ambas posições mutuamente excludentes.

O autor defende uma perspectiva que possa incorporar, de forma indissociada, à análise da gestão, os níveis institucional, organizacional e comportamental, permitindo as interseções entre a ação humana, a dinâmica da organização e o contexto macroestrutural. Essa 
perspectiva é denominada de gestão como "prática social" e pode ser identificada a partir de cinco fatores distintos, porém, inter-relacionados (REED, 1989, p. 22):

\footnotetext{
A classe de ações nas quais os praticantes estão engajados como membros de uma comunidade de prática;

Os conceitos por meio dos quais certos objetivos ou problemas compartilhados são identificados de um modo significativo pelos praticantes como base para o engajamento em interações recíprocas;

Os objetivos ou problemas por meio dos quais a prática é tomada e como é comunicada através do vocabulário conceitual de seus praticantes;

Os meios ou recursos (materiais ou simbólicos) por intermédio dos quais o alcance de projetos importantes é buscado;

As condições situacionais ou limitadoras sob as quais as atividades recíprocas, os recursos que elas requerem e as relações que elas engendram entre os seus praticantes são configurados e conduzidos.
}

$\mathrm{Na}$ continuidade, são apresentados os fundamentos da Teoria da Estruturação (GIDDENS, 2003) e da Teoria da Transformação Social (SZTOMPKA, 2005), duas das teorias mais representativas que subsidiam essa abordagem de gestão.

\subsubsection{Teoria da Estruturação}

Nas três últimas décadas do século passado, novos estudos na área sociológica procuraram enfrentar as dicotomias entre os conceitos de objetividade e subjetividade, determinismo e voluntarismo e estrutura e ação. Um desses estudos resultou na Teoria da Estruturação. Desenvolvida por Anthony Giddens, sociólogo inglês, busca a aproximação teórica e empírica da agência humana e das estruturas sociais.

Procurando se afastar da ortodoxia sociológica predominante no século XX e associando-se às contribuições inovadoras para a teoria social, Giddens (2003) destaca três temas comuns em torno dos quais as inovações na teoria social estão sendo desenvolvidas. Primeiramente, a ênfase no caráter ativo e reflexivo da conduta humana, uma resposta às teses que enxergam o comportamento humano como resultado de forças que os atores não controlam, nem compreendem. Segundo, é atribuído um papel fundamental à linguagem e às faculdades cognitivas na explicação da vida social. Terceiro, um aumento no distanciamento entre as ciências naturais e as sociais, e de suas bases epistemológicas.

A dualidade da estrutura é o conceito central em sua teoria. Em resumo, as estruturas configuram a ação das pessoas, mas é também essa mesma prática que constitui e reproduz as 
estruturas. Nesse sentido, a agência humana e a estrutura, no lugar de dicotômicas, constituem-se uma à outra (SEWELL, 1992).

Estruturas são ativadas pelo que Giddens (2003) denomina de "cognoscitividade" dos agentes humanos - o que os agentes sabem acerca das razões por que atuam e como atuam - e os agentes agem pondo em prática necessariamente essa estrutura de conhecimento.

Essa perspectiva da ação humana não apenas como uma reação aos determinismos estruturais permite visualizar um espaço de criatividade e inovação a partir das estruturas de conhecimento e capacidades acumuladas pelos agentes no tempo e no espaço. Dependendo do grau de poder de cada agente, de sua capacidade de influenciar outros grupos sociais, sua ação pode ter como conseqüência a transformação da própria estrutura que permitiu que ele agisse inicialmente (SEWELL, 1992), caracterizando um processo de mudança contínuo, fundamentado na estrutura e na ação.

Essa nova perspectiva também reduz a concepção de estabilidade e mudança como pólos opostos, geralmente sendo a primeira entendida como ruim para a organização e a segunda, como boa. Compreender o processo de estruturação implica em reconhecer momentos de equilíbrio provisório e dinâmico, de homogeneidade e heterogeneidade e de recursividade entre estrutura e agência, exigindo novos métodos de pesquisa e novos modelos (esquemas) analíticos. Ou seja, pensar a ação humana nas organizações como construção ou fenômeno social envolve a análise conjunta da própria ação, bem como os efeitos de determinadas propriedades estruturais sobre essa ação, seja restringindo-a e/ou facilitando-a (GIDDENS, 2003).

Dessa análise, segundo o próprio Giddens (2003, p. XXXVI), o que tem de ser empiricamente determinado é "até que ponto as práticas localizadas e estudadas numa determinada gama de contextos convergem entre si de modo a ingressarem diretamente na reprodução do sistema". Poder-se-ia perguntar, por exemplo, retomando o foco da tese, até que ponto a experiência da EACH, como um fenômeno (episódio) importante no contexto do ensino superior brasileiro, integrar-se-á às propriedades estruturais que ordenam o ensino superior no Brasil, ou, de forma mais localizada, às estruturas da própria USP? 
Junquillo (2005, p. 1) consegue resumir acertadamente esse processo desenvolvido na teoria de Giddens, podendo-se perceber em sua assertiva abaixo, alguns dos elementos centrais no esquema analítico a ser proposto na tese - ação e estrutura/contexto/relações histórico, sociais e culturais:

\begin{abstract}
A ação humana nas organizações é definida a partir de um processo de construção social que ocorre ao longo do tempo e do espaço, constituindo-se num conjunto de práticas complexas e distintas que depende, dentre outros fatores, da maneira particular como cada ator organizacional apreende papéis a ele designados, da relação com outras pessoas, bem como dos contextos culturais nos quais estão inseridos (Whitley, 1989; Stewart, 1989; Watson, 1994). Toma-se, ainda, como pressuposto, que aquela mesma ação é resultado de práticas sociais (Reed, 1989) e, como tal, deve ser compreendida a partir de relações histórico-sociais em uma dada sociedade (Alvesson \& Willmott, 1996), isto é, vinculando-se ação e estrutura, por meio de um processo dinâmico de construção e reconstrução da vida social, caracterizado por aquilo que Giddens $(1979,1984)$ denominou de dualidade da estrutura.
\end{abstract}

Destaque-se o caráter processual do termo estruturação, em oposição à idéia estática de estrutura, mais comum na teoria organizacional. Na Teoria da Estruturação, estrutura possui um conceito particular e está relacionado com:

O conjunto de regras e recursos implicados, de modo recursivo, na reprodução social; as características institucionalizadas de sistemas sociais têm propriedades estruturais no sentido de que as relações estão estabilizadas através do tempo e do espaço (GIDDENS, 2003, p. XXXV).

As regras representam convenções sociais em que o seu conhecimento, pelos atores, inclui também o conhecimento dos contextos nos quais se aplicam, constituindo-se como guias de orientação para a conduta humana. Os recursos referem-se às capacidades (inclusive organizacionais) à disposição dos atores para fazerem as coisas acontecerem.

As regras não podem ser vistas como prescrições formalizadas, como, por exemplo, quando são relacionadas a jogos. Segundo Giddens (2003), na reprodução dos sistemas sociais, mesmo as regras que são codificadas como leis estão sujeitas a uma diversidade muito maior de contestações do que as regras dos jogos. Para isso, contribuem os recursos que os agentes possuem ou mobilizam, sejam estes de conhecimento ou de poder, e que implicam em respostas diferenciadas e na incorporação ou não de novas práticas sociais ${ }^{9}$. Regras e recursos atuam de forma interdependente.

\footnotetext{
${ }^{9}$ Entende-se como práticas sociais, de forma similar à estrutura, como sendo a herança de tradições, normas, regras e rotinas geradas e repetidas nas atividades diárias, que alcançam assim o caráter de algo legítimo; serve de estrutura ou contexto para a práxis social, que por sua vez, são as coisas efetivamente feitas, as ações laborais, ou seja, as atividades efetivamente levadas a efeito (GIDDENS, 2003).
} 
$\mathrm{Na}$ Teoria da Estruturação as regras da vida social são mais bem entendidas como procedimentos generalizáveis aplicados no desempenho/reprodução de práticas sociais. Por meio das regras, a estrutura se aproxima da ação, da agência humana. Giddens (2003, p. 25) salienta que "a consciência de regras sociais, expressa, sobretudo, na consciência prática, é o próprio âmago daquela cognoscitividade que caracteriza especificamente os agentes humanos". Prossegue destacando que:

\begin{abstract}
Como atores sociais, todos os seres humanos são altamente 'instruídos' no que diz respeito ao conhecimento que possuem e aplicam na produção e reprodução de encontros sociais cotidianos; o grande volume desse conhecimento é, em sua maioria, de caráter mais prático do que teórico. [...] Os atores empregam esquemas simbolizados (fórmulas) no decorrer de suas atividades diárias para resolver rotineiramente as situações da vida social (Ibid. , p. 25-26).
\end{abstract}

Convêm agora esclarecer um pouco mais os conceitos de cognoscitividade, agente e agência, consciência discursiva e consciência prática, intencionalidade e consequências impremeditadas, poder e contexto, fundamentais para a compreensão da Teoria da Estruturação e para a tese.

Para Giddens (2003), todos os seres humanos são cognoscitivos. Isso significa que: "todos os atores sociais [o autor utiliza os termos ator e agente como sinônimos] possuem um considerável conhecimento das condições e conseqüências do que fazem em suas vidas cotidianas" (Ibid., p. 331). A cognoscitividade implica também a familiaridade do ator social com os contextos em que as ações humanas ocorrem. Para que a produção e reprodução social ocorram é necessário que os atores desenvolvam um conjunto compartilhado e comum de conhecimentos. Deve ficar claro que isso não significa consenso, mas expectativas de atuação próprias de um determinado grupo social e que permitem graus diferenciados de confiança entre os atores.

Diversos autores na área organizacional elaboraram conceitos sobre agentes e agência. Selznick (apud MACHADO-DA-SILVA et al, 2005) destaca que agência denota competência, intencionalidade e calculabilidade. Todo agente quando atua tem um propósito. Depreende-se que toda ação implique conhecimento e habilidade para ser executada, uma razão definida previamente e controle e previsibilidade dos resultados. 
A visão de Giddens (2003) é, em parte, diferente. O agente é um ser dotado de consciência discursiva, consciência prática e motivos inconscientes/cognição. A consciência discursiva é a mais evidente nos atores, sendo estes capazes de descrever em termos discursivo o que fazem e as razões por que o fazem. A consciência prática poderia ser comparada com o nível préconsciente na psicanálise, ou, com devidos ajustes, com o conhecimento tácito da psicologia (Polany), é a ação que ocorre no fluxo da conduta do dia-a-dia. Para Giddens - e também para Nonaka e Takeuchi (2008), em outro contexto - não existe uma fronteira rígida entre esses dois tipos de consciência ou conhecimento, o grau de permeabilidade depende das oportunidades de aprendizado e disseminação do conhecimento dos atores em interação.

Os motivos inconscientes são os mais difíceis de serem identificados, mas emergem quando eventos "fora da rotina" ou provocados (um novo projeto) passam a ser desenvolvidos na organização. Para a Teoria da Estruturação, a consciência prática é conceito central e implica na utilização de métodos investigativos capazes de 'extraí-la' dos atores.

Do conceito de agente busca-se definir a natureza da agência ${ }^{10}$. Parte-se da premissa que a rotina da vida cotidiana ocorre como um fluxo de ação intencional, entretanto, os atos têm consequências impremeditadas. Giddens (2003, p. 12) define uma ação intencional como: “o que caracteriza um ato que seu perpetrador sabe, ou acredita, que terá uma determinada qualidade ou desfecho e no qual esse conhecimento é utilizado pelo autor para obter essa qualidade ou desfecho". Essa definição de agência implica certa separação entre fazer e pretender. Para o autor nem tudo o que é feito está relacionado com intencionalidade. Completando, para o autor, "as consequências do que os atores fazem, intencionalmente ou não, são eventos que não teriam acontecido se eles tivessem se comportado de modo diferente, mas cuja realização não está ao alcance do poder dos agentes (independentemente de quais eram suas intenções)" (Ibid., p. 12).

Esses dois conceitos (evento e consequências) são centrais para a tese. Uma das causas da complexidade do processo estratégico é o fato de ele ser constituído por diversos eventos que

\footnotetext{
${ }^{10}$ Essencialmente, a agência humana deve ser entendida como uma atribuição, habilidade ou capacidade individual e/ou coletivamente possuída, a qual, à luz da noção de recursividade enxergada na interdependência entre estrutura e ação social, opera enquanto vetor dos processos de institucionalização e desinstitucionalização, mediante práticas sociais espaçotemporalmente sustentadas e orientadas por estruturas cognitivas individuais e coletivas (OLIVEIRA; SEGATTO, 2009, p. 7).
} 
ocorrem em tempo e espaço diferenciados. Não há como prever as consequiências desses eventos. Talvez seja possível certo ordenamento em torno de um projeto, caso este conquiste legitimidade entre os atores. Nessa perspectiva, outro aspecto importante para a efetividade do processo é o tempo, pois quanto mais distante esses eventos do "fenômeno originário" (projeto ou intenção estratégica) menos controle e poder pode ser exercido pelos agentes e o surgimento de conseqüências não previstas será maior.

Para Giddens (2003), a relação entre agência e poder é intrínseca. Ou seja, o poder não é um recurso a serviço do agente, mas algo que ele possui para poder atuar. Ser capaz de atuar de outro modo significa:

Ser capaz de intervir no mundo, ou abster-se de tal intervenção, com o efeito de influenciar um processo ou estado específico de coisas. [...] A ação depende da capacidade do individuo de "criar uma diferença" em relação ao estado de coisas ou cursos de eventos preexistentes. Um agente deixa de o ser se perde a capacidade para "criar uma diferença", isto é, para exercer alguma espécie de poder (Ibid., p. 17).

Poder, numa perspectiva da dualidade da estrutura, pressupõe relações pautadas em autonomia relativa e na dependência entre atores ou coletividades em contextos de interação social. Para Giddens (2003), mesmo nos sistemas hierarquizados, sempre há recursos disponíveis para os atores dos diversos níveis influenciarem-se em suas atividades. Também, não restam dúvidas que poder neste sentido, mais do que vontade ou capacidade de decidir, significa conhecimento, habilidade e competência para perceber quando e como agir.

Esses conceitos elencados acima só podem ser investigados a partir das contextualidades de interação. Assim, contexto, nesta perspectiva, assume uma perspectiva mais localizada e interdependente da ação e da interação: a) as fronteiras espaço-temporais (sendo usualmente marcos simbólicos ou físicos) em torno das faixas de interação; b) a co-presença de atores, possibilitando a visibilidade de uma diversidade de expressões faciais, gestos corporais, linguagem e outros veículos de comunicação; c) percepção consciente e uso desses fenômenos reflexivamente para influenciar ou controlar o fluxo de interação.

Para contextualizar, Giddens desenvolve ainda os conceitos de episódio e conjuntura. Caracterizar um aspecto da vida social como episódio "é vê-lo como um certo número de atos ou eventos com um começo e um fim especificáveis, envolvendo assim uma determinada 
seqüência" (GIDDENS, 2003, p. 287). Tratar algo como episódio significa "penetrar analiticamente na "História", ou seja, identificar certos elementos como marcando a abertura de uma seqüência de mudança e descrever essa seqüência como um processo de transmutação institucional" (Ibid., p. 288).

Deve-se ressaltar que o autor analisa mudança em larga escala, ou seja, no nível social maior e que sua teoria deve ser transposta para um nível mais próximo do organizacional se aplicada na análise de organizações, tarefa que Pettigrew (1987), por primeiro, e os pesquisadores da abordagem de estratégia como prática, em seguida, procuraram empreender.

Ao considerar os episódios como aspectos importantes para a análise da mudança, Giddens (2003, p. 288) salienta outro aspecto:

Se toda a vida social é contingente, toda mudança social é conjuntural. Quer dizer, depende de conjunções de circunstâncias e eventos que podem diferir em natureza de acordo com variações de contexto, quando o contexto (como sempre) implica a monitoração reflexiva, pelos agentes envolvidos, das condições em que eles fazem história.

O autor conceitua conjuntura como a interação de influências que, num determinado tempo e lugar, são relevantes para um dado episódio. Salienta que a interpretação dessas influências a partir da cognoscitividade humana potencializa a mudança social.

No caso específico da tese, episódio pode ser considerado a criação e implantação da EACH. Ou seja, um fenômeno com potencial para promover mudanças na USP. A criação e o seu desenvolvimento dependeram da interpretação de aspectos conjunturais pelos agentes em ação, cuja análise permitirá uma melhor compreensão de como ocorreu o processo.

Finalmente, deve-se salientar que a fundamentação teórica da Teoria da Estruturação não deverá restringir a elaboração do esquema analítico aos seus pressupostos, em razão, primeiramente, da abrangência da Teoria o que impede, em função de espaço e foco, maior detalhamento dos outros conceitos que a constitui. Segundo, há necessidade de aproximá-la da teoria das organizações e dos processos organizacionais, sendo este, como destacado, um intento ainda em construção, para o qual esta tese pretende colaborar. 
Mais próximo ao objetivo da tese - a elaboração de um esquema analítico capaz de contribuir para a interpretação do processo estratégico ocorrido quando da criação de uma nova unidade em uma universidade - são os estudos sobre transformação social de Piotr Sztompka (2005) que tendo por fundamento alguns dos conceitos de Giddens, desenvolve uma abordagem com novos usos de conceitos, o que resultou em um inventivo modelo interpretativo da realidade.

\subsubsection{O Modelo de Transformação Social de Piotr Sztompka}

$\mathrm{Na}$ tentativa de sintetizar e aperfeiçoar as principais idéias das teorias da agência e da moderna sociologia histórica Sztompka (2005) constrói um modelo capaz de apreender a constituição e funcionamento dos processos de transformação social.

O autor distingue dois níveis de realidade social: o das individualidades e o das totalidades. $\mathrm{O}$ primeiro é constituído de pessoas, como indivíduos ou como membros de coletividades concretas (grupos, associações, comunidades, movimentos etc.). O segundo é constituído de totalidades sociais abstratas de tipo supra-individual que representam a realidade social sui generis (sociedades, culturas, civilizações, formações socioeconômicas, sistemas sociais (incluindo as organizações) etc.). As totalidades sociais não são interpretadas nem como simples aglomerados nem como entidades metafísicas, mas como estruturas; os indivíduos sociais, por seu turno, não são vistos como objetos passivos nem como sujeitos totalmente autônomos, mas como agentes interligados (SZTOMPKA, 2005).

Acrescenta uma segunda distinção, relativa aos dois modos de existência da realidade social: $\mathrm{o}$ das potencialidades e o das realidades. O primeiro refere-se às tendências inerentes, germes ou sementes do futuro, capacidades, aptidões, poderes etc. O segundo aos processos, transformações, desenvolvimento, conduta, atividades.

Segundo Sztompka (2005, p. 364):

\footnotetext{
Ambos os modos de existência podem ser assumidos por cada um dos principais componentes do mundo social. As estruturas podem ser tratadas como potencialidades que se concretizam (desdobrando-se) na operação e os agentes como potencialidades que se concretizam (mobilizando-se) na ação. Aplicando um corte transversal sobre as duas dicotomias (de níveis e modos), chegamos aos quatro conceitos que formam as pedras angulares do nosso modelo: estruturas e agentes, operações e ações.
} 
O autor relaciona os elementos da estrutura quádrupla de modo vertical e horizontal, conforme demonstrado no quadro 1 :

Quadro 1 - Modelo Sztompka (Parte 1)

\begin{tabular}{|c|c|c|}
\hline & Potencialidade & Realidade \\
\hline Totalidade & Estrutura & Operação \\
\hline Individualidade & Agente & Ação \\
\hline
\end{tabular}
FONTE: SZTOMPKA, 2005, p. 364.

Na dimensão vertical, postula as relações complementares de emergência e autonomia. As estruturas são consideradas emergentes em relação aos agentes: ainda que os englobem, elas possuem propriedades e regularidades específicas. São redes interagentes, não redutíveis à soma dos mesmos. Mas os agentes também não são redutíveis à sua localização estrutural; eles possuem um certo grau de autonomia, integridade e liberdade relativa para escolher e decidir. São entidades auto-suficientes, com propriedades e regularidades específicas, e não meros pontos nodais das estruturas.

A relação vertical entre operação e ação é descrita de forma similar a anterior. A operação das estruturas - funcionamento da sociedade e das organizações - deve ser tratada como emergente em relação às ações executadas pelos agentes. Ainda que as ações constituam, em última instância, a substância da operação da sociedade ou da organização, não são a ela redutíveis; ao combinar diversas ações inter-relacionadas, a operação adquire o seu próprio momentum, padrão ou lógica sequencial específica. Ela é mais do que a soma das ações.

Resumindo esta etapa do modelo, o autor afirma que:

As estruturas são emergentes estáticos em relação aos agentes, ainda que não possam existir estruturas sem os agentes. Paralelamente, a operação é um emergente dinâmico em relação às ações, ainda que não possa existir operação sem ações (SZTOMPKA, 2005, p. 364).

A relação horizontal entre as dimensões do quadro também pode ser analisada. Entre agentes e ações, o conceito de mobilização sintetiza seu funcionamento. Os agentes mobilizam suas capacidades, aptidões, necessidades, atitudes e disposições potenciais, que correspondem as suas caracterizações, ao praticar ações de todo tipo. Eles fazem isso, utilizando-se também de estruturas mentais formadas ao longo da vida. 
Pode-se questionar, abrindo-se um parêntesis: o que leva os agentes a utilizarem suas capacidades nas ações - grupos similares, novos valores emergentes, interesses comuns, uma conjuntura propícia?

No nível superior, entre as estruturas e seu funcionamento (operação), ela será captada por meio do conceito de desdobramento. Segundo Sztompka (2005, p. 366):

\begin{abstract}
As estruturas se desdobram em operações, descarregando, em seu funcionamento, as suas potencialidades, tendências e disposições inerentes. Por exemplo, elas tendem a se romper e mudar quando permeadas por contradições, tensões ou restrições; ao contrário, é provável que operem de maneira uniforme quando internamente homogêneas e harmoniosas. Elas tendem a produzir estagnação quando indiferenciadas e centralizadas e tendem a se desenvolver quando pluralísticas e descentralizadas.
\end{abstract}

Isto ficou evidente quando do diagnóstico da unidade em estudo. A EACH apresenta uma estrutura mais descentralizada, permeada por contradições e tensões o que acaba por permitir a experimentação. Por outro lado, está imersa em uma estrutura maior, da USP, homogênea e centralizada, principalmente em suas normas e regulamentos, o que constitui um 'freio' a essas experiências. Imerso nessa dialética é que o processo estratégico ocorre.

Desenvolvendo um pouco mais o seu modelo, o autor insere um nível intermediário entre os dois apresentados anteriormente. O nível da agência (enquanto potencialidade) e da práxis (enquanto realidade). Segundo Sztompka (2005, p. 367) "é aqui, na interface, entre estruturas e agentes, operações e ações, que o enigma da transformação social deve ser investigado", é aqui que ocorre a trama social motriz-estrutural.

Salienta, em seguida:

Não se trata de que agentes e estruturas interajam produzindo efeitos. Ao contrário, a realidade
motriz-estrutural, em sua realidade interna, imanente, aparece com combinações diversas, misturas
diversas dos ingredientes propulsores e estruturais que constituem os eventos sociais (Ibid. , p.
368, grifo nosso). A matéria definitiva, os componentes reais de que é feita a sociedade são os eventos, nem atos individuais nem "fatos sociais", mas sua fusão íntima, concreta. A realidade organizacional ocorre nessa fusão - nos eventos - em que combinações diversas de estruturas e agentes (ingredientes inseparáveis) se manifestam. Pode-se de alguma maneira afirmar que nos eventos ocorrem as ações estratégicas, materialização da própria estratégia. Ao se estudar os 
eventos como um núcleo motriz-estrutural, portanto, a interseção de ação e estrutura, está se estudando o núcleo do processo estratégico.

No modelo de Sztompka, este adota o termo práxis, emprestado de Marx, Gramsci e Lukács, como o resultado (síntese dialética) do núcleo motriz. São as manifestações reais da trama social ao contínuo desenrolar dos eventos sociais. Práxis pode ser definida como:

[...] É onde se encontra a operação e a ação: síntese dialética do que está acontecendo em uma sociedade e do que as pessoas estão fazendo. Representa a confluência das estruturas em operação e dos agentes em ação, produto combinado do momentum da operação (ao nível das totalidades) e do curso das ações empreendidas pelos membros da sociedade (ao nível das individualidades). [...] Ela é uma qualidade nova, emergente (Ibid., p. 369).

Agência nessa perspectiva é potencialidade, ou seja, um conjunto de aptidões, disposições, tendências inerentes à trama social que propicia o seu aparecimento, resume certas propriedades da trama social. "É onde se encontram as estruturas (capacidade de operação) e os agentes (capacidade de ação); é um conjunto sintético, uma fusão de circunstâncias estruturais e capacidade propulsora" (SZTOMPKA, 2005, p. 370).

Agência e práxis no modelo de Sztompka se ligam horizontalmente pelo processo de “eventuação". "Trata-se, novamente, da confluência de concretizações que ocorrem em outros níveis: a fusão do desdobramento de estruturas com a mobilização dos agentes" (SZTOMPKA, 2005, p. 370). É um processo contingente, podendo ser concretizado em graus diversos ou pode também permanecer latente ou inativo.

O quadro 2 sintetiza os elementos da segunda etapa do modelo e suas relações apresentadas:

Quadro 2 - Modelo Sztompka (Parte 2)

\begin{tabular}{|c|c|c|c|}
\hline & Potencialidad & & Realidade \\
\hline Totalidade & Estruturas & $-------\rightarrow$ & Operação \\
\hline Realidade & Agência & - - - - & Práxis \\
\hline Individualidade & Agentes & $\ldots--\cdots$ & Ação \\
\hline
\end{tabular}

FONTE: SZTOMPKA, 2005, p. 370. 
O trabalho de Sztompka é amplo e complexo e foge ao objetivo da tese um maior detalhamento. Porém, dois últimos elementos de seu modelo são essenciais para fundamentar o esquema analítico a ser proposto: tempo e história.

Para o autor, quando se fala do desdobramento das estruturas em operação, ou da mobilização dos agentes na ação, ou ainda da eventuação da agência na práxis, "assumimos claramente uma dimensão temporal; todos esses processos só podem ocorrer no tempo" (SZTOMPKA, 2005, p. 380).

Há dois tempos implicados nesse processo: o tempo interno (de funcionamento) e o externo (da transformação). O tempo de funcionamento de uma sociedade é marcado pela reprodução de formas aceitas, sobre as quais pouca inovação ocorre. Reconhece-se que os eventos produzem mudanças, mas estas, se vistas em uma perspectiva histórica não são transformadoras.

Lloyd afirma que a agência humana e a ação social estão dialeticamente relacionadas às estruturas ao longo do tempo e assim apresenta as possíveis formas dessa relação:

Ele propõe reter a dimensão temporal como intrínseca a qualquer estudo da sociedade, uma vez que estrutura, ação e comportamento estão relacionados de maneira dinâmica, transformadora, e especifica uma sequência em que aqueles três aparecem: 1) As circunstâncias dadas, que propiciam ou obstaculizam a ação; 2) a ação consciente, que é historicamente significativa e 3) as consequências esperadas e inesperadas da ação, que se tornam condições objetivas e aparentemente inalteráveis de ação e pensamento (apud SZTOMPKA, p. 381, grifo nosso).

De toda forma, um evento é consequência de eventos anteriores e fundamento para eventos futuros. Todos os elementos do modelo sofrem impactos a partir desse processo. Isso pode ser descrito assim:

Os eventos sociais, que fundem a operação estrutural e a ação propulsora (ou simplesmente práxis) em um dado instante de tempo, influenciam tanto as estruturas (modificando ou conformando novas redes relacionais) quanto os agentes (modificando ou conformando suas capacidades imanentes) em um momento posterior. Como resultado, uma agência nova ou modificada aparece. $\mathrm{O}$ potencial da sociedade para a práxis foi alterado. A agência se manifesta, se e quando se concretiza na eventuação, como uma nova práxis que por sua vez expressa a fusão da operação das novas estruturas com a ação dos novos agentes. Por seu turno, a nova práxis dá início, em um instante posterior, a um ciclo analógico que, através das estruturas e agentes modificados, da agência modificada e de sua concretização, resulta no surgimento de uma práxis modificada ulterior. Esta sequência continua indefinidamente, produzindo incessantes transformações cumulativas da sociedade. Ela representa aquilo que entendemos por história, por oposição ao funcionamento interno da sociedade (SZTOMPKA, 2005, p. 382, grifo nosso). 
Encontra-se na afirmação acima a fundamentação teórica não apresentada por Van de Ven (1992) sobre a sua sequência de eventos. Esta, como no esquema analítico a ser proposto na tese, refere-se mais ao modo de funcionamento da sociedade ou de uma determinada organização. A transformação social proposta por Sztompka inicia no funcionamento de determinada sociedade, passa por processos de mudança social e conclui na própria transformação social, um processo que implica um tempo maior para ocorrer.

Apesar desta distinção, ao se analisar uma sequência de eventos torna-se essencial a referência ao curso da história de uma determinada organização, podendo-se buscar esses condicionantes históricos na tradição histórica, mais precisamente, em momentos que marcaram a mudança nas potencialidades e realidades de uma dada organização.

Ressalte-se uma questão final. Há no modelo de Sztompka a ausência de um maior detalhamento sobre o conceito de estruturas no nível da realidade, ou seja, da operação. Podese tentar fazer uma correlação com o conceito de estrutura em Giddens com suas regras e recursos, porém este também possui certa imprecisão. Assim, aproximando-se da teoria organizacional, pode-se assumir que as operações (Sztompka) e as estruturas (Giddens) são representadas, no nível organizacional, pelos sistemas organizacionais, os elementos da organização que potencializam, interferem ou fazem a intermediação entre contexto histórico, social e cultural (totalidade) e agentes (individualidades).

Ainda é possível mais uma divisão interna. As regras da estrutura podem ser analisadas como estruturas mais institucionalizadas, que oferecem mais restrições e limitações às ações dos agentes. Podem ser exemplificadas como a estrutura organizacional e a cultura da organização. São acumulações que ocorrem ao longo de um tempo maior e sobre as quais a ação dos agentes é menos influente. Os recursos são processos organizacionais sobre os quais os agentes possuem um grau de interferência maior, cuja durabilidade na organização dependerá da persistência da ação dos agentes, como exemplo: a tecnologia, os processos de gestão de pessoas, a gestão estratégica, os modos de liderança, os processos decisórios, os jogos políticos etc. Esta proposição será um pouco mais desenvolvida quando da elaboração do esquema analítico, no quarto capítulo. 
Em seguida, será feita uma revisão sobre estratégia em organizações, nas abordagens processuais e de prática, detendo-se um pouco mais na abordagem como processo de Van de Ven, esperando por esse meio, ampliar os fundamentos teóricos no campo da teoria organizacional que sirvam também como subsídios para a construção do esquema analítico e para a melhor interpretação e explicação do fenômeno em análise.

\subsection{Estratégia em Organizações}

Estratégia em organizações possui significados variados segundo os diferentes pressupostos presentes nas teorias organizacionais. Qualquer empreendimento de síntese sobre as diversas concepções dos pesquisadores sobre a temática é fadado ao fracasso. O que se busca a seguir estará limitado ao estudo de perspectivas e aspectos mais próximos aos fatos verificados quando da análise empírica do caso e que podem subsidiar as relações conceituais e interpretativas do esquema analítico que se busca desenvolver.

Antes de abordar categorizações ou tipologias sobre o item em análise, são apresentadas duas questões gerais que podem caracterizar a situação atual no campo. A primeira destaca que a tradição econômica da pesquisa em estratégia, muito associada ao business e ao marketing, priorizou os resultados imediatos particularizados no aumento da competitividade das organizações, disso resultando sua sobrevivência e saúde financeira. O avanço da modernidade, e segundo alguns autores, sua substituição por um período que pode ser denominado de 'após modernismo' (WHITTINGTON, 2004), levou a ampliar a visão dos benefícios da estratégia para a sociedade como um todo e não somente para as empresas. Desloca-se de uma visão predominantemente técnica incorporando-se aspectos políticos e críticos à teoria organizacional e à estratégia (REED, 1989).

A segunda questão, de ordem interna às organizações, resume o seguinte: a tradição que firmou a estratégia como um processo racionalizado, cuja formulação é responsabilidade dos executivos de nível superior e consultores e a execução aos gestores de nível médio e inferior da organização, vem sendo contestada. Atualmente, há uma maior atenção à participação de todos os agentes, ao mesmo tempo em que são empreendidos estudos visando uma maior compreensão dos procedimentos organizacionais envolvidos no processo estratégico. Isto 
implica em avanços no campo da gestão, com a incorporação de outras disciplinas, e também na necessidade de elaboração de novos procedimentos analíticos para a pesquisa.

As duas questões resumem o desenvolvimento de uma nova abordagem no campo, a sociológica, que analisa a estratégia como uma prática social, uma ação construída na organização, mas envolvendo a transformação da sociedade. A estratégia possuindo um forte apelo sociológico: está preocupada com o direcionamento de poderosas instituições, tanto da esfera pública quanto da privada (WHITTINGTON, 2004). Os efeitos das decisões e os custos envolvidos são de interesse de toda a sociedade.

Entre as tipologias da estratégia, Hatch (2002), em uma abordagem que separa claramente a organização do seu ambiente, afirma existirem três perspectivas distintas: a estratégia como tomada de decisão racional, como processo emergente e como ação simbólica. Os proponentes do modelo racional tratam a organização como uma ferramenta nas mãos dos dirigentes superiores e concebem a estratégia como um processo de designing ('projetar') a organização para encontrar um propósito pré-definido.

Aqueles que empregam a abordagem emergente vêem a organização como adaptativa e apresentam várias versões sobre a forma como as organizações se ajustam ao seu ambiente. Mas, de um modo geral, desse ajuste depende a sobrevivência da organização ou sua aceitação perante os stakeholders. Nas duas perspectivas, os aspectos do ambiente considerados de forma prioritária são os econômicos e tecnológicos.

Os que analisam a estratégia na perspectiva simbólica se utilizam de uma metáfora cultural, capaz de dar suporte às ações empreendidas na organização. O ambiente é constituído por um conjunto mais abstrato de instituições socialmente construídas e legitimadas. Uma organização, na sua formulação de seus projetos, deve buscar o mais alto grau de legitimação para se efetivar.

Chaffee (1985) apresentara anteriormente tipologia semelhante. Para o autor, o conceito de estratégia havia emergido por meio de três modelos mentais distintos - o linear, o adaptativo e o interpretativo. O modelo linear, largamente adotado, foca no planejamento. $\mathrm{O}$ termo linear foi escolhido porque denota ação metódica, direcionada e sequencial envolvida no planejamento. Para esta visão, estratégia consiste de “decisões integradas, ações ou planos que 
irão alcançar com êxito os objetivos organizacionais" (OLIVER, 1992, p. 90). Também é a determinação dos objetivos de longo prazo e, para alcançá-los, a organização altera sua relação com o ambiente modificando seus produtos ou tomando outras ações empreendedoras. Os termos associados a esta visão incluem planejamento e execução estratégica.

A forma adaptativa, que caracteriza o modelo adaptativo, implica o esforço dos estrategistas em promover o alinhamento da organização com o seu ambiente, sendo este determinista em relação às ações empreendidas na organização.

O modelo interpretativo é baseado em um contrato social ao invés das visões mecânica e biológica apresentadas no modelo linear e adaptativo. Este modelo traz contribuições, entre elas "à administração de significados e construção simbólica como componente central da estratégia e sua ênfase em legitimidade, ao invés de lucros, produtividade, ou outros típicos objetivos" (CHAFFEE, 1985, p 93). Em suma, "o modelo interpretativo, como o nível cultural de sistemas, busca enfatizar as ações cooperativas de indivíduos, os significados partilhados e a importância da manipulação de símbolos" (TAKAHASHI e MACHADO-DASILVA, 2002, p. 4).

Ao analisar a abordagem de Chaffee, Whipp (2004) afirma que ela não é suficiente para analisar as variações complexas envolvidas na construção da estratégia e que há necessidade de procurar apoio nas descobertas que surgiam na análise organizacional.

Autores como Mintzberg, Ahlstrand e Lampel (2000), identificam dez escolas, nas quais cada uma enfocaria um processo do objeto complexo da estratégia, são elas: as escolas prescritivas do design (processo de concepção), do planejamento (formal) e do posicionamento (analítico); as escolas descritivas do tipo empreendedora (visionário), cognitiva (mental), aprendizagem (emergente), poder (negociação), cultural (coletivo) e ambiental (reativo); e a escola de configuração (transformação). Críticos a esse tipo de classificação afirmam que essas visões tendem a fragmentar ainda mais o processo analítico.

Os próprios autores salientam que uma estratégia real é o somatório dessas escolas afirmando:

Podemos concluir que nossas dez escolas olham para o mesmo processo, cada uma à sua maneira. Em conjunto, esperamos, elas podem auxiliar os executivos a ver através de tudo isso. [...] 
Precisamos ir além da estreiteza de cada escola: precisamos saber como este animal chamado formação de estratégia, combina todas essas escolas, e mais, vive realmente a sua vida. (MINTZBERG et al, 2000, p. 273-274).

Na busca por uma tipologia capaz de agrupar as diferentes visões no campo e aproximá-las das pesquisas empreendidas na área das organizações, Whittington (2002) distingue quatro abordagens genéricas: a clássica, a evolucionária, a processualista e a sistêmica.

$\mathrm{Na}$ abordagem clássica, a estratégia "é o processo racional de cálculos e análises deliberadas, com o objetivo de maximizar a vantagem no longo prazo" (WHITTINGTON, 2002, p. 3). O mundo pode ser previsível e pode ser moldado desde que se ordenem as informações necessárias e tomem-se as decisões corretas por parte dos dirigentes no topo da organização. Dominar os ambientes internos e externos depende de um bom planejamento.

Segundo Whittington (2002), para os evolucionistas, a estratégia emerge a partir de forças ambientais fora do controle dos gerentes. A metáfora biológica caracteriza um processo de seleção natural, no qual o mercado seleciona as organizações mais aptas a sobreviverem. Aos gerentes cabe o papel de ajustarem suas organizações o melhor possível às exigências do ambiente onde atuam.

Os processualistas são céticos quanto ao planejamento de longo prazo e à implacabilidade do ambiente sobre a organização. Acreditam na capacidade dos gerentes, porém muito mais num processo pragmático de aprendizado e comprometimento e em experiências baseadas no acerto e no erro em razão da compreensão limitada dos processos nos quais a organização está imersa. De uma perspectiva interna à organização, as teorias processualistas tendem a conceber o fenômeno da estratégia "como influenciado tanto pela intenção de racionalidade dos agentes, quanto por interesses, compromissos e limites de natureza variada, resultando em escolhas que podem ser fruto até mesmo de processos habituais ou puramente simbólicos". (CRUBELLATE, 2004, p. 83). "Estratégias (...) são um meio pelo qual gerentes tentam simplificar e ordenar o mundo que é complexo demais e caótico" (WHITTINGTON, 2002, p. 27).

A abordagem sistêmica "propõe que os objetivos e as práticas da estratégia dependem do sistema social específico, no qual o processo de desenvolvimento da organização está inserido" (WHITTINGTON, 2002, p. 4-5). Os diferentes objetivos que guiam os estrategistas 
passam a estar mais relacionados com a cultura na qual a organização está imersa do que com a busca racional por melhores resultados. Nem sempre as razões para uma decisão tomada pode ser explicada funcionalmente, há necessidade de estabelecer conexões entre fatores externos e internos a partir do pensamento dos estrategistas. "Formas e metas do desenvolvimento de estratégias dependem particularmente do contexto social, e que, portanto, a estratégia deve ser empreendida com sensibilidade sociológica" (WHITTINGTON, 2002, p. $5)$.

As visões processualistas e sistêmicas apesar de muitos aspectos em comum, focam, verdadeiramente, nos extremos de uma linha imaginária entre ação (processualismo) e contexto/estrutura (sistemicismo), no âmbito da qual o esquema analítico a ser construído na tese se fundamentará. A seguir, aprofundam-se alguns aspectos relacionados com os conceitos de ambiente, processo e fazer estratégicos.

Segundo alguns autores, a partir da evolução das teorias organizacionais com base no modelo dos sistemas abertos, o ambiente deixou de ser apenas um fator das análises organizacionais e passa a ser um agente central nas explicações dos fenômenos organizacionais (MINTZBERG et al, 2000). "A construção de interpretações sobre o ambiente é uma necessidade básica dos indivíduos e das organizações" (DAFT; WEICK, 2007, p. 236).

BULGACOV et al (2007, p. 54) destacam a relação indissociável entre análise ambiental e formulação da estratégia da organização:

\footnotetext{
Pensar no direcionamento e atuação organizacional sem considerar de modo consistente o ambiente é incoerente com a abordagem contemporânea de estratégia. Isso significa levar em conta não somente os aspectos concretos e objetivos do ambiente, mas também o quê e como é percebido o ambiente.
}

Conceitos e modos de percepção sobre o ambiente estão inter-relacionados e devem orientar os pressupostos e modelos de análise ambiental e instrumentos de análise estratégica dos gestores organizacionais. Dependendo das bases conceituais e da forma de percepção da realidade pelos tomadores de decisão, a organização poderá seguir uma diretriz mais determinista ou mais voluntarista. A incomunicabilidade entre essas duas abordagens tem impedido muitas vezes uma análise mais integrada e real da organização e de seu ambiente por parte dos pesquisadores. As diferenças entre as abordagens determinista e voluntarista 
ocorrem, principalmente, em torno do grau de objetividade do ambiente e da capacidade proativa da organização perante as mudanças ambientais e são descritas a seguir.

Para Wilson (1992), existem três possibilidades analíticas sobre o ambiente. Na primeira, o ambiente é um fato objetivo (físico e social), ao qual, cabe ao homem responder de forma reativa e racional. $\mathrm{Na}$ segunda, o ambiente continua constituindo-se de fatores externos e tangíveis, "mas que só afetam a organização mediante processos subjetivos, de natureza cognitiva e cultural, isto é, mediante a percepção e interpretação dos agentes" (apud CRUBELLATE, 2004, p. 48). Uma terceira forma de análise é conceber o ambiente como uma construção social. Nesse caso, os ambientes não são apenas interpretados ou ordenados, mas de fato criados e recriados pelos indivíduos em suas interações, e pelas próprias ações organizacionais (WEICK, 1973).

Seguindo a primeira perspectiva, Hall (1984) afirma que o ambiente organizacional pode ser definido como o conjunto de todos os fenômenos externos à população de organizações em análise que a influenciam de forma real e/ou potencial. Fischmann e Almeida (2007, p. 19) conceituam ambiente da organização como "tudo aquilo que tem influência em seu desempenho e que a organização nada ou muito pouco pode fazer para modificá-lo". Para os autores, análise ambiental é o processo de levantar, selecionar e analisar as variáveis relevantes para a empresa, tanto dentro como fora da organização. Serve como subsídio ao planejamento estratégico da empresa, no sentido de identificar ameaças e oportunidades futuras, contribuindo para sua eficácia (FISCHMANN e ALMEIDA, 2007).

Os autores desenvolvem um modelo de análise ambiental no qual estão integrados elementos do ambiente geral (dimensões econômica, tecnológica, legal, demográfica), de um ambiente mais próximo à organização, denominado por eles de ambiente operacional, mas também relacionam aspectos interpretativos a partir da análise dos valores dos atores organizacionais. O quadro 3 apresenta os principais elementos do modelo de análise ambiental proposto pelos autores. 
Quadro 3 - Modelo de Análise Ambiental

\begin{tabular}{|c|c|c|c|}
\hline $\begin{array}{c}\text { Classificação } \\
\text { Ambiental }\end{array}$ & Variáveis Ambientais & Características & Instrumentos \\
\hline $\begin{array}{c}\text { Macroambiente } \\
\text { Clima }\end{array}$ & $\begin{array}{l}\text { Relações de poder } \\
\text { (fatores políticos), } \\
\text { Economia. } \\
\text { Ex. PIB, inflação, } \\
\text { política governamental, } \\
\text { legislação, etc. }\end{array}$ & $\begin{array}{l}\text { A previsão do clima pode ser } \\
\text { de curtíssimo prazo ou uma } \\
\text { tendência a longo prazo. Um } \\
\text { mesmo fator pode ser benéfico } \\
\text { para uma empresa e prejudicial } \\
\text { para outra. }\end{array}$ & $\begin{array}{l}\text { Opinião de experts. } \\
\text { Cenários econômicos } \\
\text { (econometria). } \\
\text { Brainstorming. }\end{array}$ \\
\hline $\begin{array}{c}\text { Macroambiente } \\
\text { Solo }\end{array}$ & $\begin{array}{l}\text { Variáveis relativas à } \\
\text { população, que fornece a } \\
\text { receita necessária para } \\
\text { manter e desenvolver a } \\
\text { empresa. Ex. } \\
\text { crescimento, renda, etc. }\end{array}$ & $\begin{array}{l}\text { As transformações são lentas e } \\
\text { previsíveis. A análise deve ser } \\
\text { feita na dimensão adequada a } \\
\text { empresa. }\end{array}$ & $\begin{array}{l}\text { Extrapolação de } \\
\text { tendências. } \\
\text { Previsões exponenciais. }\end{array}$ \\
\hline $\begin{array}{c}\text { Ambiente } \\
\text { Operacional }\end{array}$ & $\begin{array}{l}\text { Organizações e pessoas } \\
\text { externas à empresa, mas } \\
\text { que poderão interferir na } \\
\text { sua performance. Ex. } \\
\text { concorrentes, } \\
\text { fornecedores, clientes, } \\
\text { etc. }\end{array}$ & $\begin{array}{l}\text { A análise é feita em função do } \\
\text { tamanho e tipo da empresa. } \\
\text { Muitas vezes uma } \\
\text { concentração de concorrentes } \\
\text { pode ser benéfica, } \\
\text { transformando a área num } \\
\text { ponto especializado. }\end{array}$ & $\begin{array}{l}\text { Cenários. } \\
\text { Simulação de modelos. } \\
\text { Projeções Delphi. } \\
\text { Análise de impactos } \\
\text { cruzados. } \\
\text { Análise morfológica. }\end{array}$ \\
\hline $\begin{array}{l}\text { Ambiente } \\
\text { Interno }\end{array}$ & $\begin{array}{l}\text { É a parte humana e } \\
\text { incontrolável da } \\
\text { organização. Ex. Valores } \\
\text { e aspirações das pessoas. }\end{array}$ & $\begin{array}{l}\text { Fusões podem alterar o } \\
\text { desempenho da organização } \\
\text { devido ao choque da cultura } \\
\text { organizacional. A previsão } \\
\text { deste segmento ambiental para } \\
\text { as empresas é realizada pela } \\
\text { análise da cultura } \\
\text { organizacional do grupo. }\end{array}$ & $\begin{array}{l}\text { Mapas cognitivos. } \\
\text { Análise da cultura } \\
\text { organizacional. }\end{array}$ \\
\hline
\end{tabular}

Fonte: FISCHMANN E ALMEIDA, 2007.

Segundo Daft e Weick (2007), na abordagem clássica de estratégia, a organização presume que o ambiente externo é concreto, que os eventos e processos são sólidos, mensuráveis e determinantes. A chave está na descoberta por meio de levantamentos de informação, análise racional, cautela e mensuração precisa. Essa organização utilizará pensamento linear e lógico e buscará dados e soluções que sejam claros.

Críticos a essa abordagem destacam, porém, que algumas organizações - e claramente a do tipo universidade - possuem características multifacetadas, pluralísticas, que tornam a análise 
do ambiente mais complexa, tendo esta de ser vista de forma sistêmica e processual, envolvendo atividades dos agentes e variáveis organizacionais "que não foram captadas em outras abordagens" (DAFT; WEICK, 2007, p. 236). Os indivíduos envolvem-se em ações e essas ações constituem uma realidade coletiva que deve ser interpretada a partir de aspectos objetivos e subjetivos.

Ou seja, a realidade é ordenada ao se "fabricar um sentido" (sensemaking) (WEICK, 1995), o que "implica em converter experiências e eventos em algo inteligível por meio do entendimento das relações e dos elementos que os constituem" (FONSECA; MACHADODA-SILVA, 2002, p. 103). A realidade é construída.

Freidberg (1993, p. 93) avança nessa concepção ao destacar que:

[...] Para compreender a instituição do meio ambiente, tem de se reconstruir os processos de interação concretos entre os membros de uma organização colocados nos seus diferentes níveis e os seus interlocutores respectivos nos diferentes segmentos concretos de meio ambiente.

Teóricos institucionalistas defendem uma abordagem intermediária entre as citadas acima, aliando aspectos objetivos do ambiente com processos cognitivos dos agentes organizacionais. Para isso, além do ambiente operacional ou técnico, destacam a existência de um ambiente institucional, sendo que este:

Realça a elaboração e a difusão de regras e procedimentos aos quais as organizações se devem conformar para obter apoio e legitimidade contextual. Tais requisitos procedem do Estado, de redes profissionais e, até mesmo, de empresas concorrentes, que avaliam as organizações pela adequação do arranjo estrutural às suas exigências (FONSECA; MACHADO-DA-SILVA, 2000, p. 104).

Para esses institucionalistas existem regras e normas às quais as organizações se submetem tendo em vista serem reconhecidas em um dado setor social, obtendo recursos para a sua sobrevivência. Mas, essas regras e normas precisam ser interpretadas pelos agentes a partir de um contexto organizacional, contexto este marcado por uma história que constitui uma cultura sob a qual seus agentes orientam seus valores e crenças, agrupados em esquemas interpretativos, podendo ser estes decodificados por meio de mapas cognitivos (BARTUNEK, 1984). 
Neste momento, procede abrir um parêntesis para abordar um pouco mais a questão do conceito de contexto. Na tese, prefere-se adotar o conceito de contexto no lugar de ambiente. Justifica-se, em parte, pelo viés objetivista e muitas vezes estático (como uma fotografia) como a interpretação do ambiente ocorre no campo majoritário dos estudos sobre estratégia e pela existência de uma clara delimitação entre ambiente e organização na abordagem clássica desta.

Por outro lado, ao se buscar a fundamentação nas teorias da prática social, o conceito de contexto parece melhor apreender a dinâmica da ação social e a importância dada aos conceitos de espaço, tempo e história nessas teorias.

Concorda-se com Whitaker (1998, p. 111) o qual, entendendo o contexto como um delineador do "campo epistemológico" para os tomadores de decisão, define o termo como,

a interação da herança genética, da tradição cultural, das experiências passadas e das circunstâncias em desenvolvimento, e como o conjunto das estruturas institucionais existentes, os quadros cognitivos e imaginários que os envolvidos trazem consigo e rotineiramente concretizam nas situações de ação

Pode-se também identificar as variáveis componentes do contexto na afirmação a seguir:

[...] Forças institucionais, histórias organizacionais, culturas, estruturas de grupo e estruturas de poder. Padrões institucionais, tais como normas e valores organizacionais, e também crenças e regras ambientais impõem limites prévios sobre a ação dos agentes. (HUYSMAN, 2001, p. 87).

Como exemplo de uso do conceito de contexto em análises educacionais, apresenta-se a abordagem de Ball e Bowe (1992). Com foco na análise da formulação e implementação de políticas educacionais, os autores propuseram um ciclo contínuo de análise constituído por três contextos principais: o contexto de influência, da produção de texto e da prática. Esses contextos estão inter-relacionados, não têm uma dimensão temporal ou seqüencial e não são etapas lineares. Cada um apresenta arenas, lugares e grupos de interesse e cada um deles envolve disputas e embates.

No contexto de influência é onde normalmente as políticas públicas são iniciadas e os discursos políticos são construídos. É nesse contexto que grupos de interesse disputam para influenciar a definição das finalidades sociais da educação e do que significa ser educado. 
Atuam nesse contexto as redes sociais dentro e em torno de partidos políticos, do governo e do processo legislativo. É também nesse contexto que os conceitos adquirem legitimidade e formam um discurso de base para a política (MAINARDES, 2006). Ressalte-se que política no nível organizacional pode ser considerada como sinônimo de estratégia. De alguma forma, foi nesse contexto que surgiram as políticas afirmativas do Governo Federal brasileiro e que mobilizaram ações nas universidades.

O contexto de produção de texto é o cenário dos textos políticos, portanto, representam a política. Essas representações podem tomar várias formas: textos legais oficiais e textos políticos, comentários formais ou informais sobre os textos oficiais, pronunciamentos oficiais, vídeos etc. Segundo Mainardes (2006) tais textos não são, necessariamente, internamente coerentes e claros, e podem também ser contraditórios. Eles podem usar os termos-chave de modo diverso. A política não é feita e finalizada no momento legislativo e os textos precisam ser lidos com relação ao tempo e ao local específico de sua produção. Os textos políticos são o resultado de disputas e acordos, pois os grupos que atuam dentro dos diferentes lugares da produção de textos competem para controlar as representações da política. Assim, políticas são intervenções textuais, mas elas também carregam limitações materiais e possibilidades.

De acordo com Ball e Bowe (1992), o contexto da prática é onde a política está sujeita à interpretação e recriação e onde a política produz efeitos e conseqüências que podem representar mudanças e transformações significativas na política original. Para estes autores, o ponto-chave é que as políticas não são simplesmente "implementadas" dentro desta arena (contexto da prática), mas estão sujeitas à interpretação e, então, a serem "recriadas" (apud MAINARDES, 2006, p. 53).

No esquema a ser construído, essa diferenciação de contextos será abolida. O contexto, os agentes e os sistemas organizacionais estão imersos em torno de ações interativas. O contexto apresenta-se como potencialidade e realidade constituinte da e constituído pela ação estratégica.

Na continuidade, abordam-se elementos do processo estratégico, detendo-se nas questões de formulação e de implementação. 
O processo estratégico define o modo como as estratégias de uma organização são formuladas (elaboradas) e implementadas. Em sentido similar ao explorado na tese,

[...] o conceito de processo tem sido aplicado para descrever como e por que as estratégias são elaboradas e desenvolvidas, ou seja, busca-se desvendar de que modo são tomadas as decisões e ações que dizem respeito à execução estratégica, incluindo assimilação e reação a interferências externas. Além disso, buscam-se explicações das conseqüências geradas a partir de padrões decisórios e/ou de ações tomadas no decorrer do tempo (BULGACOV et al, 2007, p. 85, grifo nosso).

Ao se aprofundarem os estudos sobre o processo estratégico percebeu-se que entre suas características incluem-se a dinamicidade e multiplicidade de níveis em que as ações ocorrem. Neste sentido, o processo inclui a sobreposição e interação de múltiplos níveis de análise, ou seja, é um fenômeno que abrange mais do que simplesmente os níveis hierárquicos formais da organização. "Inclui interações entre os indivíduos, entre grupos, entre grupos e estruturas, entre grupos e rotinas, entre organizações e setores industriais e entre setores e políticas econômicas" (BULGACOV et al, 2007, p. 86).

Relaciona-se, em parte, com o lado menos racional da estratégia, com o cotidiano organizacional, processos decisórios e formas de participação. É um fenômeno em que se percebe a influência dos sistemas organizacionais, como a cultura, a estrutura, as relações de poder, as coalizões, as relações entre pessoas e entre grupos e pessoas.

$\mathrm{O}$ aspecto da formulação tem sido bastante analisado e vários pesquisadores têm procurado apresentar uma visão menos determinística do que a grande maioria dos estudos até então oferecia. Assim, a estratégia tanto pode ser formulada de forma premeditada e enunciada em plano estratégico a priori, como emergir como padrão historicamente contingente de ações interdependentes que, organizadas retroativamente sob o ponto de vista do presente, são enunciadas posteriormente. Observe-se que formulação, formação e elaboração nesta última abordagem podem ser utilizadas como sinônimos.

Para Nicolau (2001, p. 8), a forma como as estratégias surgem e se implementam não é um processo idêntico em todas as organizações, "resultando antes de uma conjugação de fatores externos (características e condições do meio envolvente) e de condições internas (dimensão, capacidades materiais e humanas, organizacionais), que configuram cada situação particular". 
A partir de levantamento bibliográfico, Nicolau (2001) define três linhas básicas de formulação da estratégia: a) como um processo racional e formal; b) como um processo negociado; c) como um processo em construção permanente.

Os autores que consideram a formulação como um processo racional e formal afirmam que ela se desenvolve por meio de etapas sequenciais, racionais e analíticas. "O plano, estrutura através da qual o processo se formaliza, conduzindo a explicitação das estratégias aos vários níveis da empresa, é o instrumento fundamental para uma gestão de sucesso" (NICOLAU, 2001, p. 9).

A estratégia como processo negociado concebe a organização mais como um corpo social do que como uma unidade técnico-econômica, assim, "as pessoas têm objetivos [e interesses], em razão disso a formulação da estratégia é um processo de negociação entre grupos sociais internos [e externos] à empresa, o que constitui uma restrição à racionalidade econômica" (NICOLAU, 2001, p. 10).

A elaboração como uma construção permanente destaca a complexidade do processo e que nem sempre a estratégia se desenvolve por meio de processos claros, ordenados e controlados nem se encontra explícita em qualquer documento. "Vai-se formando por meio da aprendizagem sobre o ambiente, capacidades internas da organização e a forma apropriada de estabelecer uma relação entre elas" (NICOLAU, 2001, p. 12).

Hart (1992), ao empreender estudos sobre o processo de formação de estratégia, constatou que três temas eram recorrentes na literatura: racionalidade (perfeita e limitada), visão e participação.

Segundo o autor, e semelhante à Hatch (2002), Chaffee (1985) e Whitington (2002), as pesquisas fundamentadas na racionalidade perfeita, se concentram na capacidade do gestor, ou de um grupo de gestores em utilizar a racionalidade para elaborar a estratégia, controlar deliberadamente sua implementação pelos funcionários (top down) e obter resultados econômicos (decisões perfeitas). Por sua vez, os pesquisadores que admitem a racionalidade imperfeita se concentram nos limites cognitivos dos modelos mentais e nas características e interesses motivacionais e políticos inerentes à racionalidade para analisar a pluralidade dos 
resultados e as limitações da capacidade do gestor (agente) em separar a elaboração e controle de sua implementação.

O tema da visão refere-se ao comportamento simbólico do gestor e na sua capacidade de liderança para motivar e permitir a participação dos funcionários na elaboração da estratégia e na sua implementação (HART, 1992).

O tema da participação resume as publicações que se concentram na capacidade do gestor em permitir a autonomia dos funcionários na elaboração, implementação e controle (button-up), e ajustar esta estratégia emergente à estrutura da organização.

Hart (1992), em um trabalho de síntese a partir desses três temas citados acima e focando as expectativas de papéis entre gestores e funcionários, chegou a cinco tipos de comportamentos quando da elaboração da estratégia, apresentados no quadro 4.

Quadro 4 - Tipologia Hart

\begin{tabular}{|c|c|c|c|c|c|}
\hline \multirow{2}{*}{ DIMENSÕES } & \multicolumn{5}{|c|}{ TIPOLOGIAS } \\
\hline & Comando & Simbólica & Racional & Transacional & Genérica \\
\hline Estilo & $\begin{array}{l}\text { (Imperial) } \\
\text { A estratégia } \\
\text { é gerenciada } \\
\text { por um líder }\end{array}$ & $\begin{array}{c}\text { (Cultural) } \\
\text { A estratégia é } \\
\text { gerenciada } \\
\text { pela } \\
\text { visão e missão } \\
\text { voltadas para o } \\
\text { futuro }\end{array}$ & $\begin{array}{c}\text { (Analítico) } \\
\text { A estratégia é } \\
\text { gerenciada de } \\
\text { maneira } \\
\text { formal e } \\
\text { estruturada em } \\
\text { planos } \\
\text { sistemáticos }\end{array}$ & $\begin{array}{l}\text { (Processual) } \\
\text { A estratégia é } \\
\text { gerenciada } \\
\text { pelo ajuste } \\
\text { constante dos } \\
\text { processos } \\
\text { internos }\end{array}$ & $\begin{array}{c}\text { (Orgânico) } \\
\text { A estratégia é } \\
\text { gerenciada } \\
\text { pelos autores } \\
\text { das } \\
\text { iniciativas }\end{array}$ \\
\hline $\begin{array}{c}\text { Expectativas } \\
\text { do } \\
\text { gestor(s) }\end{array}$ & $\begin{array}{l}\text { Comandante } \\
\text { (Providenciar } \\
\text { direção) }\end{array}$ & $\begin{array}{l}\text { Treinador } \\
\text { (Motivar e } \\
\text { inspirar) }\end{array}$ & $\begin{array}{c}\text { Chefe } \\
\text { (Envolvimento } \\
\mathrm{e} \\
\text { Controle) }\end{array}$ & $\begin{array}{c}\text { Mediador } \\
\text { (Empoderamento } \\
\mathrm{e} \\
\text { Autonomia) }\end{array}$ & $\begin{array}{l}\text { Patrocinador } \\
\text { (Fomento e } \\
\text { Suporte) }\end{array}$ \\
\hline $\begin{array}{l}\text { Expectativas } \\
\text { dos } \\
\text { funcionários }\end{array}$ & $\begin{array}{l}\text { Soldado } \\
\text { (Obedeça } \\
\text { ordens) }\end{array}$ & $\begin{array}{l}\text { Jogador } \\
\text { (Responda a } \\
\text { mudanças) }\end{array}$ & $\begin{array}{l}\text { Subordinado } \\
\text { (Participe do } \\
\text { o sistema) }\end{array}$ & $\begin{array}{l}\text { Participante } \\
\text { (Aprenda e } \\
\text { articule) }\end{array}$ & $\begin{array}{c}\text { Empreendedor } \\
\text { (Experimente } \\
\mathrm{e} \\
\text { aceite riscos) }\end{array}$ \\
\hline
\end{tabular}

Fonte: HART (1992, p. 335).

O tipo comando pressupõe a existência de uma estratégia definida por um gestor ou grupo gestor, visionários e empreendedores, que em sua implementação pressupõe a existência de um líder "comandante" e de funcionários que executem ordens. 
No tipo simbólico, à semelhança de Chaffe (1985), a estratégia é elaborada deliberadamente por um grupo de gestores que exercem sua liderança e manipulam elementos da cultura organizacional para motivar os funcionários a buscar níveis elevados de desempenho. O líder manipula valores, crenças, símbolos organizacionais, ou seja, os elementos da cultura organizacional, por meio, por exemplo, de um novo projeto, no intuito de alcançar apoio e participação.

A estratégia formulada por meio de planos estruturados é denominada por Hart de racional. Pressupõe o uso de técnicas e ferramentas de formulação e acompanhamento por parte dos gestores. Necessita do envolvimento dos funcionários quando da obtenção de informações do ambiente externo e interno no intuito de ajustar a estratégia às mudanças que ocorrem nesses ambientes. O líder é um chefe e o funcionário um subordinado, porém, participante do sistema.

No tipo transacional, elaboração e implementação são indissociáveis. Os gestores precisam estar atentos aos sinais oriundos das interações entre os diversos agentes nos diversos níveis em que estas ocorrem. O processo de aprendizagem é recorrente, tanto entre os gestores, como entre os funcionários. O comportamento esperado do gestor é de um mediador ou facilitador. Deve estar atento às atividades que se desenvolvem na organização e buscar otimizar aquelas mais próximas aos objetivos organizacionais, procurando dar um sentido às ações empreendidas. Por seu lado, os funcionários aprendem a participar politicamente na busca por seus interesses.

No tipo genérico, a estratégia é emergente e origina-se da interação de grupos localizados na organização, portanto, de baixo para cima. São os grupos que gerenciam as suas próprias ações. O gestor atua fomentando e dando suporte às iniciativas empreendedoras dos funcionários, sendo que correr riscos faz parte do perfil desejado destes.

Percebe-se a semelhança entre as duas últimas tipologias. A diferença é no grau de autonomia dos grupos quando da elaboração da estratégia, maior no tipo genérico. Ao mesmo tempo, esta parece mais restrita a um grupo, enquanto a transacional pressupõe a interação entre grupos diferentes. 
O aspecto da implementação dá especial atenção aos fatores que influenciam em sua execução. Percebe-se que os diferentes focos de estudos sobre estratégia nas organizações dão pesos diferentes às variáveis que influenciam na implementação da estratégia.

Um recenseamento da literatura que versa sobre o tema aponta cinco abordagens principais dentre as quais os estudiosos do tema têm se divido: as abordagens de alinhamento (HREBINIAK, 2006; BOURGEOIS; BRODWIN, 1984); controle (KAPLAN; NORTON, 1992); aprendizagem (ARGYRIS, 1989); processo (CHAKRAVARTHY e DOZ, 1992; PETTIGREW, 1992; VAN DE VEN, 1992) e prática (WHITTINGTON, 2004; JARZABKOWSKI; WILSON, 2002).

$\mathrm{Na}$ sequência são destacados alguns aspectos das abordagens de alinhamento e prática. $\mathrm{Na}$ seção seguinte, a perspectiva como processo, na abordagem de Van de Ven, será mais detalhada.

Em uma perspectiva funcionalista, Hrebiniak (2006) desenvolve um modelo sobre execução da estratégia. Para o autor fazê-la funcionar é mais difícil do que formulá-la. A execução representa "um processo disciplinado ou um conjunto lógico de atividades conectadas que permite que uma organização utilize uma estratégia e a faça funcionar" (Ibid., p. 23). O desafio é resultado de uma série de fatores habituais, incluindo políticas, inércia e resistências à mudanças.

Para vencer o desafio da execução Hrebiniak (2006, p. 40) apresenta oito áreas relacionadas ao sucesso da execução:

\footnotetext{
1) Desenvolver um modelo para orientar as ações de execução; 2) entender como a criação da estratégia afeta a sua execução; 3) gerenciar a mudança de forma efetiva, incluindo as mudanças culturais; 4) entender o poder e a influência e usá-lo para o sucesso da execução; 5) desenvolver estruturas organizacionais que estimulem o compartilhamento das informações, a coordenação e uma clara responsabilidade; 6) desenvolver controles efetivos e mecanismos de feedback; 7) saber como criar uma cultura de suporte à execução; 8) aplicar a liderança com viés para a execução.
}

A execução, para o autor, depende de uma boa estratégia ou de um planejamento adequado. A figura 1 demonstra as principais decisões e ações envolvidas na execução da estratégia. 


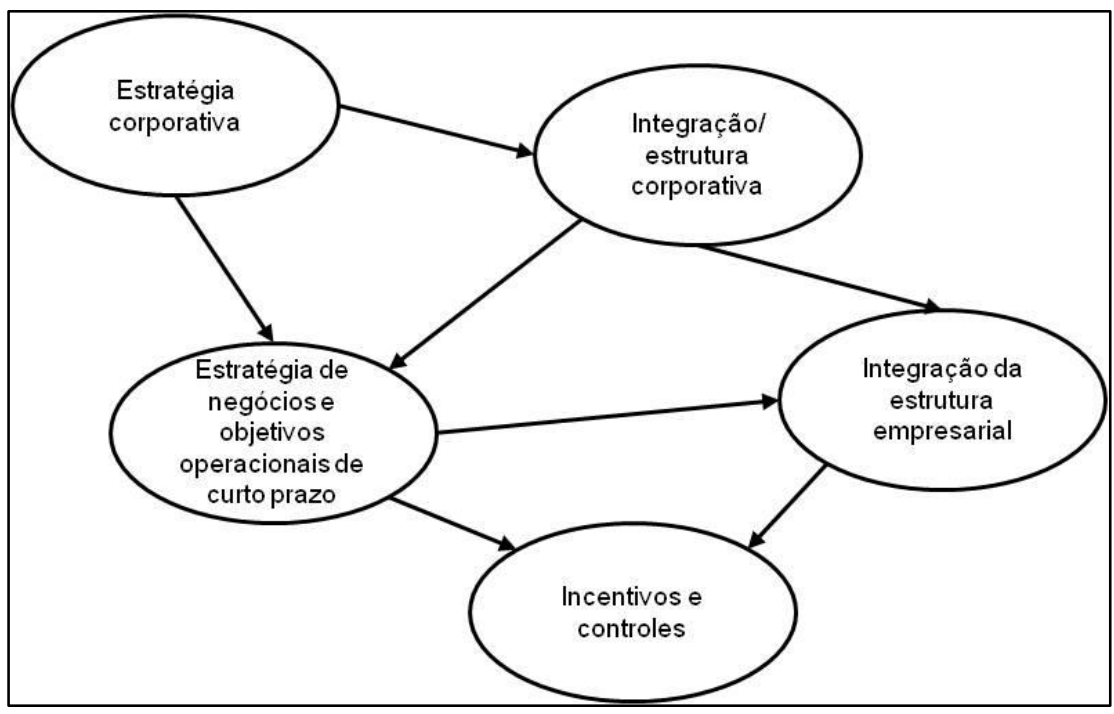

Figura 1 - Executando as Estratégias: Decisões e Ações Fonte: HREBINIAK, 2006, p. 53

As setas indicam um fluxo lógico de decisões ou ações de execução e compreendem a estratégia corporativa (de onde tudo deve partir) até chegar aos incentivos e controles (que devem recompensar e reforçar as decisões corretas). A estrutura organizacional retrata as maiores partes ou unidades operacionais que compõem toda a empresa. A estratégia de negócios está relacionada aos produtos, serviços e em como concorrer em um dado setor. A estrutura empresarial corresponde às estruturas mais apropriadas à determinadas unidades de uma organização. Mas, somente esse fluxo não é suficiente para o modelo de Hrebiniak.

Para o autor as ações de execução ocorrem dentro de um contexto organizacional ou ambiental. Esse contexto é importante porque pode afetar os processos e resultados da execução. Hrebiniak destaca quatro fatores contextuais que afetam a execução: a) o contexto da administração de mudanças; b) a cultura da organização; c) a estrutura de poder organizacional e d) o contexto de liderança (ver figura 2). 


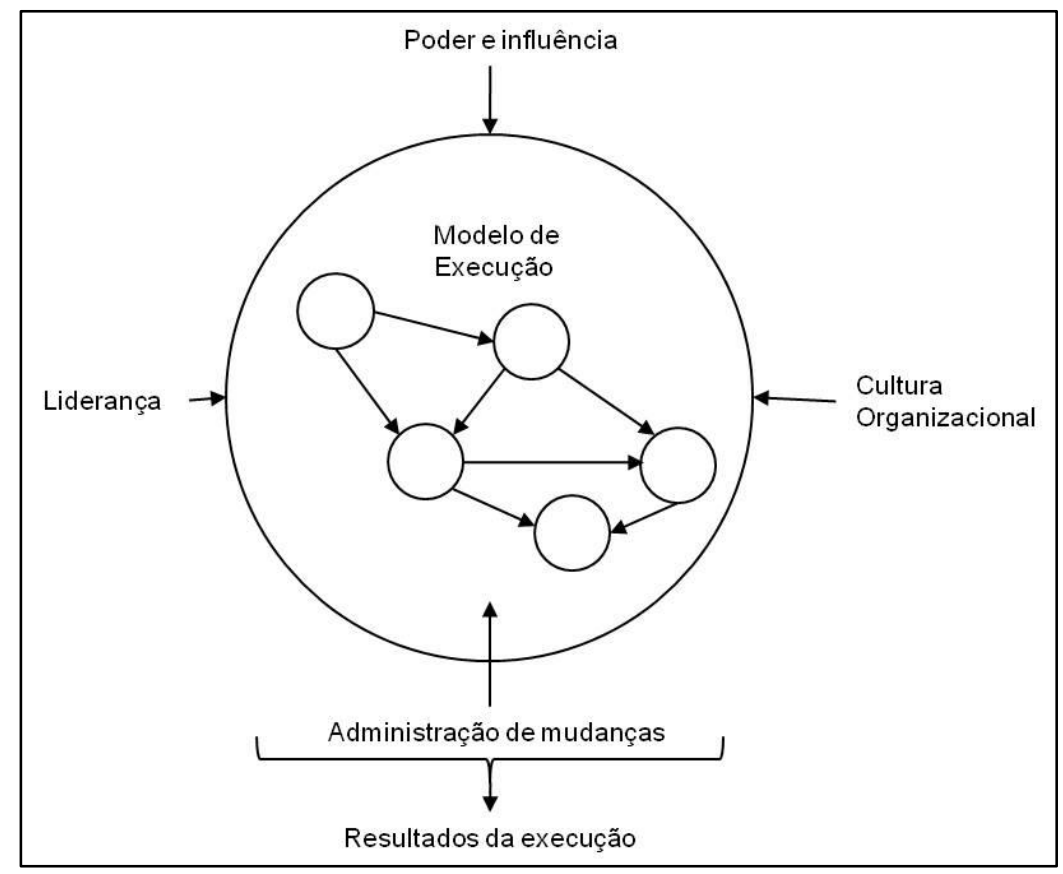

Figura 2 - Contexto das Decisões de Execução Fonte: HREBINIAK, 2006, p. 73

A abordagem de Hrebiniak define as interações entre os fatores destacados. O autor, porém, separa a execução da formulação (apesar de considerar sua interdependência). Por outro lado, uma hora denomina contexto de clima, outra de cenário, outra de ambiente, não de aprofunda nos fatos históricos e sociais que possam influenciar determinadas decisões e, diferentemente do que se pretende propor na tese, separa as ações dos agentes dos sistemas organizacionais e do próprio contexto.

Deve ser ressaltado, então, que o esquema analítico a ser elaborado na tese poderá utilizar-se dessas variáveis ou fatores contextuais, como denomina Hrebiniak (2006), mas as combinações entre elas e o processo indutivo resultante serão diferentes. Isso será possível, também, em razão do desenvolvimento de novos campos de pesquisa em estratégia, como se verá em seguida.

Para determinados pesquisadores, as abordagens de conteúdo e de processo se mostraram insuficientes "em termo de profundidade analítica pelos estudiosos interessados em delinear e descrever processos de estratégia, como a sua implementação e seu surgimento" (WILSON; JARZABKOWSKI, 2004, p. 12). Ampliou-se a abordagem processual para uma visão mais próxima ao agir que se denominou de estratégia como prática ou baseada em atividades. 
Ao comparar essa nova perspectiva dos estudos sobre estratégia com a do planejamento racional, Clegg et al (2004, p. 26) destacam, a partir de Whittington (um dos precursores dessa abordagem), que:

Ela oferece a perspectiva de evolução da estratégia de uma prática disciplinarmente normativa e prescritiva a uma prática essencialmente empírica em seu foco nos etnométodos do estrategista do cotidiano e nas utilizações que estes fazem dessas respostas disciplinares de segunda ordem. Assim, procura-se afastar a agenda estratégica das limitadas preocupações de uma ciência obscura.

Os elementos ou fatores do contexto mais focados na pesquisa em uma perspectiva baseada na prática incluem: poder, identidade profissional, agentes não humanos, ética, linguagens e instituições (CLEGG et al, 2004).

Como citado anteriormente, a análise do poder é importante para a compreensão do processo estratégico. $\mathrm{Na}$ abordagem como prática, os questionamentos para elucidação dos aspectos envolvidos nessa dualidade podem ser:

\begin{abstract}
Quais são as vozes ouvidas enquanto a estratégia é formulada? Que implicações têm, para o processo de formação, as vozes ouvidas e as silenciadas? Por exemplo, se a formulação for restrita à elite corporativa, poderá impulsionar a criatividade e a inovação? Ou tal processo servirá meramente para reproduzir os preconceitos e vieses das elites gerenciais? Entender o poder, portanto, é ir ao cerne de questões-chave: o que é admissível em um ambiente de desenvolvimento de estratégias? E por quem? Serão as organizações democráticas a ponto de perceberem e aplicarem o que James March (1988) apresentou como "a tecnologia da insensatez", em que as pessoas marginalizadas nas organizações - como os jovens, os recém-contratados ou as minorias, ou simplesmente pessoas com perspectivas diferentes - contribuem para o processo de criação de estratégias? (CLEGG et al, 2004, p. 26-27).
\end{abstract}

Percebe-se que na abordagem como prática, os agentes e os sistemas organizacionais são analisados com maior proximidade. Os autores que a utilizam fazem os seguintes questionamentos:

a) O que acontece quando as estratégias são colocadas em prática, e como os indivíduos, especialmente os gerentes, contribuem para esse processo? b) Como as organizações, com suas culturas freqüentemente sedimentadas e suas complexas estruturas, interagem com o processo e o influenciam? (WILSON; JARZABKOWSKI, 2004, p. 12).

A abordagem aprofunda a visão de que formulação e implementação são dois processos entrelaçados. A partir disso, o pensar e o agir estrategicamente estão em permanente interação. Muda-se a idéia de tomada de decisão para a de mobilizar recursos. Para agir há necessidade de constante reflexão, e esta não está desconectada do que ocorre de fato na 
organização. Os processos de fazer estratégia passam a ser vistos como uma mistura de ação (animação) e direção (orientação). Garud (1997) afirma nesse sentido que "fazer estratégia diz respeito ao conhecimento de onde e quando essas interações ocorrem no tempo e no espaço" (apud WILSON; JARZABKOWISKI, 2004, p. 13).

Os autores dessa abordagem foram buscar referências nas "teorias da prática" oriundas, principalmente, da sociologia (Giddens, Bourdieu, Sztompka) e da filosofia (Heidegger, Wittgenstein), para entender a estratégia como uma prática social (WHITTINGTON, 2004).

A estratégia como prática lida com a questão da agência a partir de três dimensões analíticas: iterativa, projetiva e prática avaliativa (EMIRBAYER e MISCHE, 1998). A agência iterativa, segundo Wilson e Jarzabkowski (2004), tende a reproduzir a prática existente. Fundamenta-se no princípio da recursividade da teoria da estruturação, no qual os atores agem a partir da reconstrução de suas experiências do passado.

A dimensão projetiva da agência envolve imaginações projetivas de futuro e retoma a imagem do estrategista como um visionário. Adota uma metáfora da escola de empreendedorismo utilizada por Mintzberg et al (2000). De alguma forma, esta escola retoma uma idéia de estratégia formulada e centralizada no topo da escola clássica.

A terceira dimensão é a prática-avaliativa. Wilson e Jarzabkowski resumem assim esta dimensão:

\footnotetext{
Mesmo quando os estrategistas projetam o futuro, não conseguem prever o resultado. Em vez disso, ao se mover na direção de suas projeções eles devem se basear nos recursos existentes, que provavelmente serão aqueles associados à agência iterativa, isto é, modelos disponíveis de se fazer estratégia. Esta dimensão da agência envolve, portanto, que atores reflitam e que sejam capazes de entender suas ações atuais dentro do contexto de ações passadas e de aspirações futuras, e que façam a mediação entre as duas coisas de forma a poder desafiar e transformar a prática existente (2004, p. 15, grifo nosso).
}

Essas três práticas, porém, ocorrem por meio de uma ação coletiva, como um processo incremental que resulta de ajustes mútuos entre grupos de interesses múltiplos e partidários. Segundo Astley e Van de Ven (2007, p. 100), embora os atores partidários persigam seus próprios interesses, "eles o fazem, no entanto, dentro de limites, e devem negociar com os demais para encontrar concessões que sejam aceitáveis de um ponto de vista coletivo". 
Essa ação coletiva, que podemos sintetizar no processo de interação entre os agentes, se dá, segundo Schatzki (apud SANTOS et al, 2006), por meio de três elementos básicos - regras, estruturas teleoafetivas e entendimentos ${ }^{11}$ - e ocorrem em um dado contexto histórico, social e cultural que muda ao longo do tempo. Os agentes participam de vários contextos em uma organização e para cada um desenvolvem conhecimentos apropriados sobre como se comportar e agir.

Por ser uma abordagem recente no campo, ainda com muita variedade interna, nos últimos anos, os autores ligados a ela têm procurado desenvolver metodologias que permitam discernir categorias e tipologias que possam ser utilizadas como condutoras dos processos de análise e coleta de dados. Por se adequarem mais aos objetivos da tese, as categorias desenvolvidas inicialmente por Jarzabkowski e Wilson (2002) e ampliadas por Valmra et al (2006) sobre o papel dos gestores na condução estratégica serão na sequência apresentadas.

Jarzabkowski e Wilson (2002) realizaram estudo sobre como os gestores da Warwick University colocaram em prática a estratégia ou, na perspectiva dos autores, como esta foi formulada e implementada. Para tanto, estruturaram a coleta de dados a partir de quatro processos principais envolvidos na relação entre os gestores e os contextos nos quais as ações se desenvolveram: 1) direção estratégica (que estabelece objetivos organizacionais e ações estratégicas); 2) alocação de recursos (para dar suporte à implementação das ações estratégicas); 3) monitoramento e controle (que monitora performance em busca dos objetivos e comportamentos desejados); 4) interação (envolvendo contato pessoal regular entre gestores e os outros membros organizacionais, para aumentar a participação em busca dos objetivos por meio de negociação, comunicação e persuasão).

\footnotetext{
${ }^{11}$ As regras se referem às formulações (leis, estatutos, normas, regras práticas de decisão, padrões implícitos de comportamento) que "aconselham" ações particulares em práticas específicas das quais os participantes estão (supostamente) conscientes e às quais precisam (supostamente) observar. As estruturas teleoafetivas dizem respeito a um mix de ações orientadas por determinados fins (teleologia) com preocupações acerca daquilo que é importante (afetividade) - a ação não está ligada apenas aos fins, mas também aos meios. O que "faz sentido" para uma pessoa fazer (projetos, tarefas, atividades), depende não só dos seus objetivos finais/intenções, mas também de suas crenças, valores, expectativas, desejos, disposição, emoções etc. Cada uma das práticas sociais tem, portanto, uma espécie de estrutura teleoafetiva que estabelece o conjunto de fins (objetivos), meios (ações) e afetos (emoções) aceitos, considerados como válidos ou legítimos, que serve de orientação para os praticantes. Os entendimentos, por sua vez, perpassam os demais elementos, na medida em que as regras e estruturas teleoafetivas não são "coisas objetivas", mas sim uma construção social que depende, em última instância, do significado (do entendimento) que os praticantes dão a elas (SANTOS et al, 2006, p. 7).
} 
Valmra et al (2006) elaboram modelo analítico com objetivo de detalhar alguns dos mecanismos por meio dos quais as práticas supra-organizacionais institucionalizadas conformam as micro-atividades e, por outro lado, como as micro-atividades conformam o processo estratégico. Do modelo construído, esta etapa apresenta maior interesse para a tese.

Desenvolvendo a proposta de Jarzabkowski e Wilson (2002) a partir dos dados obtidos em sua pesquisa, Valmra et al (2006) ampliaram os quatro processos detalhados acima para "sete funções da estratégia como prática": 1) entender a organização e o ambiente; 2) gerar novas idéias e iniciativas; 3) projetar uma estratégia formal; 4) comunicar uma direção estratégica; 5) tomar decisões estratégicas em qualquer nível de gerenciamento; 6) concordar sobre os tipos de implementação; 7) controle e ajuste.

Os autores, em seguida, estabelecem um link entre as funções identificadas em seu modelo e os cinco diferentes modos de comportamento estratégico de Hart (1992), resultando em um rico material para analisar o fazer estratégico em um fluxo de eventos, conforme quadro 5.

Quadro 5 - Modelo Valmra et al (2006)

\begin{tabular}{|c|c|c|c|c|c|}
\hline $\begin{array}{c}\text { As sete } \\
\text { atividades } \\
\text { genéricas } \\
\end{array}$ & Comando & Racional & Simbólico & Transitiva & Genérica \\
\hline $\begin{array}{c}\text { Entender a } \\
\text { organização e } \\
\text { o ambiente }\end{array}$ & $\begin{array}{l}\text { Fazer sentido } \\
\text { no topo, } \\
\text { comunicado } \\
\text { na forma de } \\
\text { ordens diretas. }\end{array}$ & $\begin{array}{l}\text { Fazer sentido } \\
\text { confia numa } \\
\text { análise formal. }\end{array}$ & $\begin{array}{l}\text { Fazer sentido } \\
\text { por meio da } \\
\text { perspectiva } \\
\text { dos modelos } \\
\text { mentais } \\
\text { introduzidos } \\
\text { pela alta } \\
\text { gerência. }\end{array}$ & $\begin{array}{l}\text { Fazer sentido é } \\
\text { feito por meio } \\
\text { da mudança de } \\
\text { informação na } \\
\text { forma de } \\
\text { comunicação } \\
\text { escrita ou } \\
\text { verbal, formal } \\
\text { ou informal. }\end{array}$ & $\begin{array}{l}\text { Fazer sentido } \\
\text { direcionado } \\
\text { pela escolha } \\
\text { individual da } \\
\text { perspectiva. }\end{array}$ \\
\hline $\begin{array}{c}\text { Gerar novas } \\
\text { ideias e } \\
\text { iniciativas }\end{array}$ & $\begin{array}{l}\text { Práticas são } \\
\text { orientadas } \\
\text { através da } \\
\text { geração de } \\
\text { novas ideias } \\
\text { somente } \\
\text { dentro da } \\
\text { equipe pela } \\
\text { alta gerência. }\end{array}$ & $\begin{array}{l}\text { As ideias e } \\
\text { iniciativas são } \\
\text { criadas como } \\
\text { parte de um } \\
\text { processo } \\
\text { analítico. }\end{array}$ & $\begin{array}{l}\text { As ideias e } \\
\text { iniciativas são } \\
\text { conduzidas } \\
\text { pela direção } \\
\text { ideológica. }\end{array}$ & $\begin{array}{l}\text { As ideais e } \\
\text { iniciativas são } \\
\text { o resultado do } \\
\text { diálogo e da } \\
\text { discussão. }\end{array}$ & $\begin{array}{l}\text { As ideias e } \\
\text { iniciativas } \\
\text { brotam como } \\
\text { um resultado } \\
\text { do espírito } \\
\text { empreendedor/ } \\
\text { inovador } \\
\text { dentro da } \\
\text { organização. }\end{array}$ \\
\hline $\begin{array}{l}\text { Projetar uma } \\
\text { estratégia } \\
\text { formal }\end{array}$ & $\begin{array}{l}\text { Não há } \\
\text { nenhuma } \\
\text { estratégia } \\
\text { projetada, ou } \\
\text { se há, ela é } \\
\text { uma } \\
\text { preocupação } \\
\text { exclusiva da }\end{array}$ & $\begin{array}{l}\text { O processo de } \\
\text { desenvolver } \\
\text { uma estratégia } \\
\text { é um processo } \\
\text { analítico } \\
\text { completo. }\end{array}$ & $\begin{array}{l}\text { A estratégia } \\
\text { estabelece } \\
\text { várias direções } \\
\text { gerais na } \\
\text { forma de um } \\
\text { ou alguns } \\
\text { conceitos/prin } \\
\text { cípios }\end{array}$ & $\begin{array}{l}\text { A estratégia } \\
\text { nasce do } \\
\text { processo de } \\
\text { discussão de } \\
\text { vários ou de } \\
\text { todos os níveis } \\
\text { de gerência. }\end{array}$ & \\
\hline
\end{tabular}




\begin{tabular}{|c|c|c|c|c|c|}
\hline & $\begin{array}{l}\text { alta direção e } \\
\text { não é } \\
\text { comunicada } \\
\text { para baixo. }\end{array}$ & & principais. & & \\
\hline $\begin{array}{l}\text { Comunicar } \\
\text { uma direção } \\
\text { estratégica }\end{array}$ & & $\begin{array}{l}\text { Uma } \\
\text { estratégia é } \\
\text { comunicada } \\
\text { na forma de } \\
\text { metas } \\
\text { estratégicas. }\end{array}$ & $\begin{array}{l}\text { A estratégica é } \\
\text { comunicada na } \\
\text { figura de uma } \\
\text { ideologia. }\end{array}$ & $\begin{array}{l}\text { As principais } \\
\text { ideias } \\
\text { estratégicas são } \\
\text { veiculadas } \\
\text { através da } \\
\text { discussão. }\end{array}$ & \\
\hline $\begin{array}{c}\text { Tomar } \\
\text { decisões } \\
\text { estratégicas em } \\
\text { qualquer nível } \\
\text { de } \\
\text { gerenciamento }\end{array}$ & $\begin{array}{l}\text { As decisões } \\
\text { estratégicas } \\
\text { são tomadas } \\
\text { somente no } \\
\text { topo da } \\
\text { organização. }\end{array}$ & $\begin{array}{l}\text { As decisões } \\
\text { estratégicas } \\
\text { são alcançadas } \\
\text { pelo uso de } \\
\text { métodos } \\
\text { analíticos. }\end{array}$ & $\begin{array}{l}\text { As decisões } \\
\text { estratégicas } \\
\text { são delegadas } \\
\text { para baixo } \\
\text { com uma } \\
\text { ideologia } \\
\text { principal } \\
\text { servindo como } \\
\text { um balizador. }\end{array}$ & $\begin{array}{l}\text { As decisões } \\
\text { estratégicas são } \\
\text { feitas por uma } \\
\text { série de } \\
\text { discussões } \\
\text { formais e } \\
\text { informais } \\
\text { resultando } \\
\text { numa decisão } \\
\text { formal. }\end{array}$ & $\begin{array}{l}\text { As decisões } \\
\text { estratégicas são } \\
\text { o resultado da } \\
\text { iniciativa } \\
\text { dentro da } \\
\text { organização, a } \\
\text { alta direção } \\
\text { atuando apenas } \\
\text { como parte } \\
\text { ratificadora. }\end{array}$ \\
\hline $\begin{array}{c}\text { Concordar } \\
\text { sobre os tipos } \\
\text { de } \\
\text { implementação }\end{array}$ & & $\begin{array}{l}\text { As formas de } \\
\text { implementaçã } \\
\text { o são } \\
\text { acordadas } \\
\text { como um } \\
\text { resultado do } \\
\text { processo } \\
\text { formal. }\end{array}$ & $\begin{array}{l}\text { O acordo dos } \\
\text { tipos de } \\
\text { implementaçã } \\
\text { o é muito } \\
\text { geral, baseado } \\
\text { no que os } \\
\text { membros da } \\
\text { organização } \\
\text { acham estar na } \\
\text { linha da } \\
\text { ideologia } \\
\text { geral. }\end{array}$ & $\begin{array}{l}\text { As formas de } \\
\text { implementação } \\
\text { são } \\
\text { combinadas } \\
\text { como um } \\
\text { resultado de } \\
\text { incutir } \\
\text { significado } \\
\text { através da } \\
\text { discussão. }\end{array}$ & $\begin{array}{l}\text { Os tipos de } \\
\text { implementação } \\
\text { são } \\
\text { combinados na } \\
\text { forma de } \\
\text { regras simples } \\
\text { de "fazer"e } \\
\text { "não fazer". }\end{array}$ \\
\hline $\begin{array}{c}\text { Controle e } \\
\text { Ajuste }\end{array}$ & $\begin{array}{l}\text { Controle e } \\
\text { ajustes são } \\
\text { baseados na } \\
\text { comunicação } \\
\text { direta para o } \\
\text { topo, com } \\
\text { ajustes } \\
\text { decididos } \\
\text { apenas pela } \\
\text { alta direção. }\end{array}$ & $\begin{array}{l}\text { Controle e } \\
\text { ajustes são } \\
\text { parte de um } \\
\text { processo } \\
\text { sistemático de } \\
\text { comunicação e } \\
\text { um processo } \\
\text { analítico para } \\
\text { tomada de } \\
\text { decisões. }\end{array}$ & & $\begin{array}{l}\text { Cobre somente } \\
\text { o lado do } \\
\text { ajuste na forma } \\
\text { de diálogo e } \\
\text { discussão sobre } \\
\text { como mitigar } \\
\text { os desvios do } \\
\text { pretendido e } \\
\text { quais tipos de } \\
\text { ajustes devem } \\
\text { ser feitos para } \\
\text { se alinhar aos } \\
\text { principais } \\
\text { pontos da } \\
\text { estratégia. }\end{array}$ & \\
\hline
\end{tabular}

Fonte: VALMRA et al (2006).

Para completar a fundamentação sobre estratégia é destacada a abordagem como processo na visão de Van de Ven (1992) e Van de Ven e Poole (1995). 


\subsubsection{Abordagem de Estratégia Como Processo de Mudança}

Inicialmente, e em razão da pesquisa teórica e empírica desenvolvida, deve ser novamente destacado como pressuposto da abordagem como processo na tese o seguinte: ao se buscar compreender os processos estratégicos que ocorrem na universidade, procura-se descobrir as condições que originam as relações dialéticas entre contexto, sistemas organizacionais e agentes em eventos definidos que ocorrem ao longo do tempo.

As teorias ("motores") sobre processo ${ }^{12}$ de mudança em organizações denominadas de ciclo de vida, teleológica, dialética e evolutiva, apresentadas por Van de Ven (1992) e Van de Ven e Poole (1995) constituem fundamentação útil para subsidiar outra "lente" explicativa de como o processo estratégico ocorre em universidades. Em razão disso, serão caracterizadas a seguir.

Nas teorias de ciclo de vida, a mudança está contida na própria organização. Significa que o desenvolvimento de uma entidade (uma organização, um grupo, um projeto) é 'geneticamente' definido, regula o processo de mudança e guia a entidade de um ponto de partida até um ponto de chegada, caminho este pré-figurado no momento presente (VAN DE VEN; POOLE, 1995). Nestas teorias, agrupam-se desde pesquisas que consideram a mudança como uma sequência linear de estágios, até pesquisas que analisam a mudança a partir de regras e normas que prescrevem uma seqüência natural de passos para a mudança. Regras e normas contextuais definem o processo de mudança. Os passos regimentais que devem ser considerados para a aprovação de um projeto de pós-graduação na universidade desde sua elaboração até a sua avaliação nos colegiados pode ser tomado como um exemplo.

As teorias de base teleológica defendem que propósitos e objetivos são as causas finais para a mudança no direcionamento de uma entidade. Assume-se que a entidade é capaz de ser propositiva e adaptativa; por sua própria conta ou em conjunto com outras, a entidade constrói ou visualiza um estado final, realiza ações nesse sentido e monitora o progresso. Proponentes

\footnotetext{
${ }^{12}$ Van de Ven (1992) define três formas de como processo é utilizado na literatura organizacional: a) como uma lógica que explica uma relação causal entre variáveis dependentes e independentes; b) como uma categoria de conceitos que se referem à ação de indivíduos, fluxo de trabalho, técnicas de tomada de decisão, bem como formulação e implementação estratégica; c) como uma sucessão de eventos que descrevem como as coisas mudam com o passar do tempo. Para o autor, somente a terceira assertiva permite observação explícita e direta do processo em ação e permite descrever como uma organização muda com o passar do tempo. Na tese, se desenvolve uma combinação muito particular dos dois últimos significados.
} 
desta teoria entendem desenvolvimento como uma seqüência repetitiva de formulação, implementação, avaliação e modificação de objetivos baseada no que a entidade aprendeu com a experiência (VAN DE VEN; POOLE, 1995). Uma das principais características desta teoria é considerar que o desenvolvimento leva a entidade até um estado final, para tanto, tornam-se importantes os recursos e as condições ou funções necessárias para alcançar esse estado. Os atores e as organizações assumem papel relevante, propositivos, porém limitados em suas ações por instituições e atores de outras entidades do ambiente.

A terceira teoria, dialética, assume que a entidade organizacional está imersa em um mundo plural em que entidades, eventos, forças e valores contraditórios competem entre si por dominação e controle. As forças opositoras podem ser internas à organização em razão de conflitos de objetivos e interesses entre grupos, assim como, podem ter origem externa, por exemplo, em grupos contrariados com certo direcionamento tomado pela organização que atinge seus interesses. Estabilidade e mudança são explicadas tendo como referência o balanço de poder entre grupos ou entidades opositores (VAN DE VEN; POOLE, 1995). Tese e antítese podem gerar uma síntese que leve à mudança, ou, ao contrário, à manutenção de um estado ou reprodução do status quo. Os atores, tanto internos como externos, constroem e manipulam as regras do jogo e procuram utilizá-las em seu favor.

Em muitas abordagens, evolução é sinônimo de mudança. A quarta teoria correspondente às teorias evolutivas em que mudança é explicada como uma recorrente, cumulativa e probabilística progressão de variação, seleção e retenção de entidades organizacionais. Embora haja um quadro bastante amplo de abordagens nesta teoria, no geral, os atores se submetem ao processo evolutivo de uma dada população organizacional.

O quadro 6 sintetiza essas quatro teorias (motores):

Quadro 6 - Teorias (motores) de processo de mudança de Van de Ven

\begin{tabular}{|c|l|l|l|l|}
\hline Motor & \multicolumn{1}{|c|}{ Ciclo de vida } & \multicolumn{1}{c|}{ Teleológico } & \multicolumn{1}{c|}{ Dialético } & \multicolumn{1}{c|}{ Evolucionário } \\
\hline \multirow{2}{*}{ Lógica } & $\begin{array}{l}\text { Programa pré- } \\
\text { concebido; } \\
\text { continuidade }\end{array}$ & $\begin{array}{l}\text { Estado final } \\
\text { vislumbrado; } \\
\text { construção social; } \\
\text { equifinalidade. }\end{array}$ & $\begin{array}{l}\text { Tese dos } \\
\text { contrários; } \\
\text { antítese; síntese }\end{array}$ & $\begin{array}{l}\text { Seleção natural } \\
\text { dos organismos e } \\
\text { das espécies }\end{array}$ \\
\hline \multirow{5}{*}{ Progressão } & $\begin{array}{l}\text { Sequência única } \\
\text { de estágios } \\
\text { alterando a forma } \\
\text { da entidade, } \\
\text { regulamentada por } \\
\text { leis naturais ou }\end{array}$ & $\begin{array}{l}\text { Sequência } \\
\text { múltipla e } \\
\text { cumulativa de } \\
\text { planejamento, } \\
\text { implementação e } \\
\text { adaptação de }\end{array}$ & $\begin{array}{l}\text { Sistemática } \\
\text { convergência de } \\
\text { múltiplas } \\
\text { progressões } \\
\text { divergentes } \\
\text { mediadas pelos }\end{array}$ & $\begin{array}{l}\text { Sequência de } \\
\text { variação, seleção e } \\
\text { retenção }\end{array}$ \\
\hline
\end{tabular}




\begin{tabular}{|c|l|l|l|l|}
\hline & institucionais & $\begin{array}{l}\text { meios alternativos } \\
\text { para alcançar o } \\
\text { estado desejado }\end{array}$ & $\begin{array}{l}\text { conflitos entre } \\
\text { valores e eventos }\end{array}$ & Intencional, \\
\hline Condições & $\begin{array}{l}\text { Programas e } \\
\text { rotinas definidos } \\
\text { pela natureza, pela } \\
\text { lógica e pelas } \\
\text { instituições }\end{array}$ & $\begin{array}{l}\text { escolha interativa, } \\
\text { ação e } \\
\text { aprendizado } \\
\text { coletivo }\end{array}$ & $\begin{array}{l}\text { Pluralistico, } \\
\text { contraditório, } \\
\text { sequência de } \\
\text { eventos ou valores } \\
\text { conflitantes }\end{array}$ & $\begin{array}{l}\text { Escassez, } \\
\text { dinâmica } \\
\text { populacional }\end{array}$ \\
\hline
\end{tabular}

Fonte: Adaptado de Van de Ven (1992).

Ainda na abordagem de Van de Ven e Poole (1995) é válido explorar sua tipologia de teorias de processo de mudança a partir de quatro aspectos: a) processo é visto como diferentes ciclos de eventos em mudança; b) o qual é governado por diferente motor ou mecanismo de geração; c) opera em uma diferente unidade de análise; d) e representa um modo diferente de mudança. A figura 3 ilustra a tipologia a partir de duas dimensões analíticas: a unidade e o modo de mudança vistos a partir das ações e processos e não em razão de suas conseqüências ou condições de início, ou ainda, em função do nível de radicalidade, como outros modelos de análise da mudança. Em razão disso, foi feita a opção de sua utilização na tese.

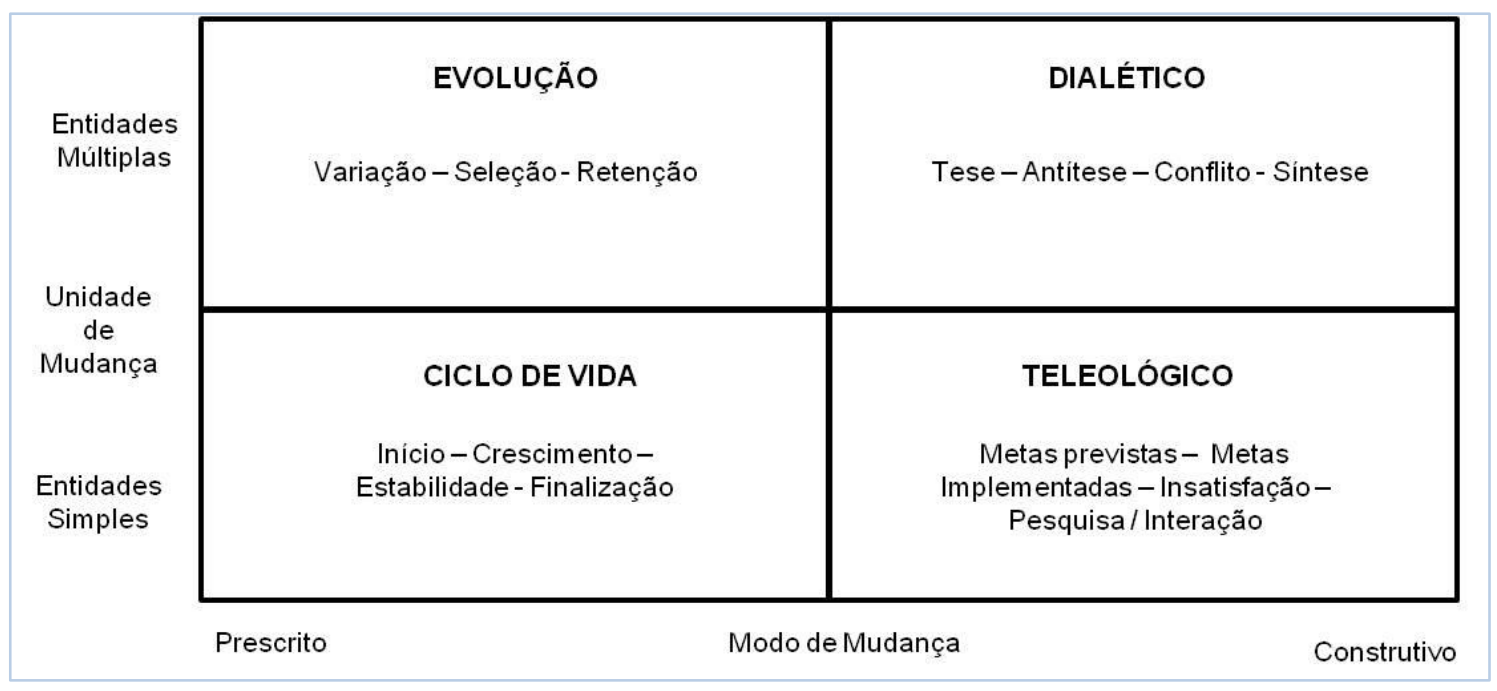

Figura 3 - Teorias de Processo de Desenvolvimento e Mudança Organizacional Fonte: Adaptado de VAN DE VEN E POOLE (1995, p. 520).

Van de Ven e Poole (1995) afirmam que processos de mudança e desenvolvimento podem ocorrer em vários níveis: o individual, o grupal, o organizacional e em um conjunto ampliado de comunidades de organizações. Convém reforçar que a tipologia estabelece tipos ideais e, portanto, estes servem como padrão de referência, mas dificilmente são encontrados na sua forma pura na realidade. A teoria evolucionária e a dialética pressupõem a existência de pelo menos duas entidades em confronto. Existem pesquisadores, principalmente os que adotam a 
escola dialética, que realizam suas pesquisas internamente a uma organização, analisando, por exemplo, o confronto entre grupos ou entre unidades.

Ao contrário das escolas citadas anteriormente, as escolas de ciclo de vida e teleológica operam com uma única entidade. Partem do princípio de que, apesar da influência externa e de esta poder mobilizar ou inibir a ação interna, a força da mudança está no interior da entidade, em potencialidades existentes (ciclo de vida) ou em um consenso em torno de objetivos a serem alcançados (teleológica).

Os modos de mudança dos quatro tipos ideais podem ser distinguidos em termos se a seqüência de eventos da mudança é prescrita a priori de forma determinística, ou se a progressão é construída ou emerge do processo de mudança. Van de Ven e Poole (1995) afirmam que no modo prescritivo de mudança o desenvolvimento da entidade é préespecificado em uma direção, tipicamente mantendo e adaptando de forma incremental uma posição de estabilidade. No modo construtivo, a mudança gera formas novas, desconhecidas na organização, caracterizando uma descontinuidade com o passado. $\mathrm{O}$ modo prescritivo evoca um conjunto de eventos em mudança de acordo com procedimentos e ações rotineiras. Em contraste, o modo construtivo, produz novas ações que podem ou não serem aceitas e tornadas rotinas na organização. Teorias de ciclo de vida e evolucionária operam na modalidade prescritiva, enquanto a teoria teológica e a dialética operam no modo construtivo.

Essa perspectiva de análise processual é bem visualizada na figura 4.

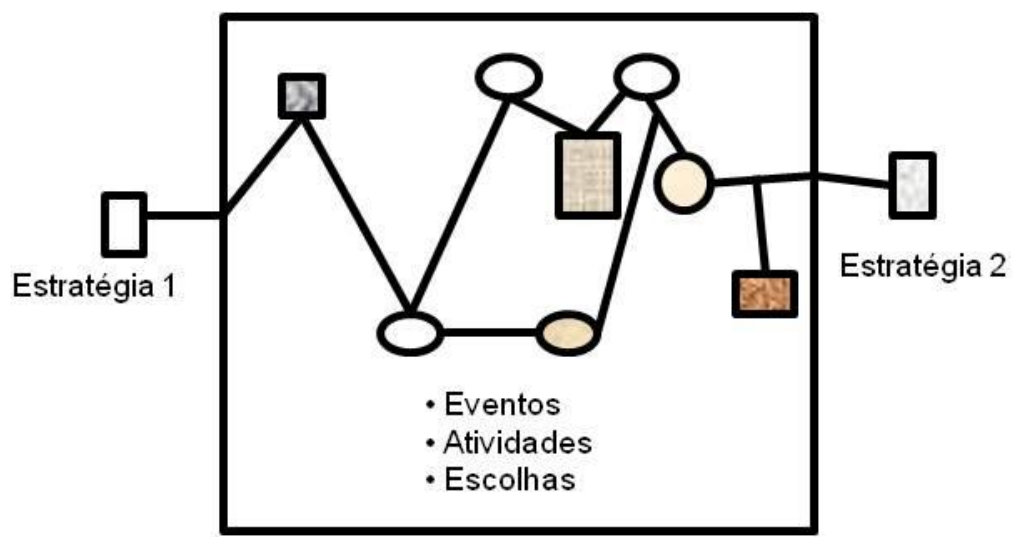

Figura 4 - Trajetória de Eventos, Atividades e Decisões Fonte: VAN DE VEN e POOLE (1995) 
A abordagem de Van de Ven e Poole (1995) salienta a existência de eventos, atividades ou rotinas e decisões que influenciam na trajetória de uma dada estratégia, acabando por modificá-la. Será fundamental para a explicação de como ocorre o processo estratégico em universidades e para subsidiar, de forma mais específica, respostas para uma das questões de pesquisa sobre conformidades e contradições dos modelos analíticos em uso na organização universidade.

Ainda é necessário refletir, de forma breve, sobre como a estratégia se apresenta nas organizações educacionais, segundo os teóricos da educação.

\subsubsection{Estratégia nas Organizações Educacionais}

A estratégia nas organizações escolares, segundo Canário (1992, p. 184), "envolve um conjunto de decisões, ações e operações que, juntas, permitem atingir objetivos visados, orientando e controlando fatores internos e externos". Para esse autor, "a estratégia materializa-se num projeto educativo, próprio de cada estabelecimento de ensino, com diferentes níveis de profissionalização, e constitui um processo, que, segundo uma lógica prospectiva, responde ao incerto e ao imprevisível" (CANÁRIO, 1992, p. 185, grifo nosso).

Um projeto educativo inovador expressa:

Finalidades e esperanças no futuro; histórias e narrações compartilhadas; objetivos globais relativos à personalidade dos alunos, seu desenvolvimento social e suas aprendizagens; concepções sobre a convivência e a maneira de enfrentar os conflitos; mecanismos para participação democrática dos diversos estamentos e a tomada de decisões; o modo como a escola se articula com o entorno; e fórmulas alternativas para mudar a destinação tradicional de tempos e espaços (CARBONELL, 2002, p. 81).

Trata-se de uma concepção que alia a abordagem clássica da estratégia, com a perspectiva processual, assim como, a visão sistêmica e cultural integradora de organização e que tem influenciado o processo educativo brasileiro em seus diferentes níveis.

$\mathrm{Na}$ universidade, esse projeto educativo se materializa no Projeto Pedagógico Institucional (PPI) e no Projeto Pedagógico de Curso (PPC).

O Projeto Pedagógico Institucional, 
constitui-se como um instrumento político, filosófico, teórico-metodológico, norteador das práticas
acadêmicas da IES, expressa a visão de mundo no contexto da contemporaneidade e especifica o
papel da educação superior enquanto ação dinâmica de uma nova conjuntura globalizada e
tecnológica sem perder de vista o seu papel e contribuição nos diferentes setores da sociedade
local e nacional, tendo em vista sua ação no âmbito do ensino, pesquisa e extensão de modo a
possibilitar a formação do cidadão crítico, criativo, dinamizado e transformador capaz de
proporcionar a articulação equilibrada entre o real e o desejável. (UEPA/PPI, 2008, p. 10).

De forma objetiva, o PPI estabelece ou reforça os princípios norteadores da universidade; a missão, visão de futuro e vocação institucional; as políticas de ensino, pesquisa e extensão; as políticas de qualificação docente e formação continuada; as diretrizes pedagógicas; e as questões sobre responsabilidade social.

Este projeto maior - quase uma filosofia educacional - estrutura e é construído em sua implementação, por vários subprojetos, sendo a maioria destes, oriundos e validados na prática diária de gestores e professores, confluindo, neste aspecto, com uma das características da burocracia profissional de Mintzberg (2006, p. 224-225): "as estratégias próprias da burocracia profissional representam o efeito cumulativo dos projetos, das 'iniciativas' estratégicas ou de experiências que seus membros estão em condições de convencer sobre sua implementação". No âmbito da análise desses subprojetos existe um vácuo teórico-empírico, pois nem os analistas da área educacional e nem os da área organizacional têm se empenhado em buscar compreendê-los.

Pois é no nível dessas iniciativas e experiências que é possível analisar com mais proximidade os eventos (Van de Ven, 1992) constituintes de fenômenos ou episódios (Giddens, 2003), sendo estes objetivados na universidade na criação de uma nova unidade, em processos de alteração ou ajustes curriculares, na elaboração de um novo projeto de curso de pósgraduação, em reformas estruturais, por exemplo.

No próximo capítulo são apresentados os fundamentos e os instrumentos metodológicos a partir dos quais foram obtidos e analisados os dados empíricos da pesquisa. 


\section{METODOLOGIA DA PESQUISA}

Este capítulo apresenta a metodologia e o modelo de pesquisa utilizados para o desenvolvimento da tese. Em razão da complexidade de buscar analisar como ocorre o processo estratégico em uma universidade e assim tentar contribuir teoricamente e empiricamente para sua interpretação e explicação, percebe-se a necessidade de integrar os estudos sociológicos aos organizacionais. Implica também em ultrapassar as fronteiras dos paradigmas organizacionais e das perspectivas dominante na análise estratégica; a de posicionamento econômico, da racionalidade perfeita e da escolha estratégica.

Dessa forma, introdutoriamente, far-se-ão algumas considerações sobre a abordagem multiparadigmática que embasa a pesquisa. Em seguida, apresenta-se o delineamento da pesquisa, universo e amostra, coleta de dados, modelo orientador e as limitações da pesquisa.

\subsection{Considerações Introdutórias}

Um estudo de um fenômeno complexo como o processo estratégico em universidades pode requerer visões diversificadas de teorias e abordagens de pesquisa em organizações e em estratégia. Ao mesmo tempo, a construção teórica de prática social que fundamenta a tese, com base na teoria da estruturação e na teoria da transformação social, pressupõe a formação de um campo social integrando o macro ao microssocial, a estrutura à ação. Daí a importância em abordar o fenômeno estratégico em uma perspectiva que aproxime, sem descaracterizar, os paradigmas sociológicos nos estudos organizacionais.

Nesse sentido, uma abordagem multiparadigmática - na qual pesquisadores "aplicam lentes ou paradigmas divergentes empiricamente, seja por meio da condução de estudos conjuntos, seja por meio da realização de estudos seqüenciais" (SCHROEDER, 2009, p. 36), parece ser uma solução mais adequada à perspectiva almejada.

Destaque-se, porém, a predominância na tese, do paradigma interpretativo, ou seja, a intenção prioritária é compreender como ocorre a ação humana a partir da interpretação dos agentes 
que a realizam. Subtende-se que não existem apenas relações causais objetivas de fenômenos sociais, comportamentais e físicos, como na filosofia funcionalista-positiva, mas que nestas relações interferem o humano, sua subjetividade, seus interesses e processos cognitivos o que tornam essas relações muito mais complexas do que aparentam ser.

A predominância do paradigma interpretativo, porém, não significa que contribuições do funcionalismo não sejam utilizadas na análise. Para melhor esclarecer essa divisão paradigmática é obrigatório retornar a Burrel e Morgan (1979) e a Morgan (1996).

Em texto considerado como referência nos estudos organizacionais, Burrel e Morgan (1979) argumentam que, de forma particular, as teorias das organizações poderiam ser analisadas em termos de quatro visões de mundo representadas em diferentes conjuntos de pressuposições metateóricas sobre; a natureza da ciência - a dimensão subjetivo-objetiva; e a natureza da sociedade - a dimensão da mudança por regulação ou por via radical. A dimensão subjetiva seria representada pelos paradigmas interpretativista e humanista radical e a natureza objetiva pelos paradigmas funcionalista e estruturalista radical. A dimensão regulatória, pelos paradigmas funcionalista e interpretativista e a dimensão de mudança radical, pelos paradigmas estruturalista radical e humanista radical.

O paradigma funcionalista possui uma visão objetivista da realidade. Significa que "busca explicações relacionadas ao status quo, ordem social, consenso, integração social e realidade, a partir de um ponto que tende a ser realista, positivista, determinista" (SCHROEDER, 2009, p. 41). Desta caracterização, no estudo do processo estratégico em universidades, ordem, consenso e integração são aspectos pouco comuns de serem constatados empiricamente, por outro lado, é certa a existência da realidade e de suas estruturas agindo de forma orientadora, ordenadora e restritiva sobre a organização e seus agentes, mesmo que a interpretação destes agentes sobre essa realidade possa ser diferenciada.

Além do ambiente real, também é assumida a existência de uma organização real, com estrutura e processos formais que atuam sobre os agentes, influenciando no resultado de suas ações e, em relação ao foco da tese, na formulação e implementação das ações que compõem um dado fenômeno estratégico. 
De um ponto de vista interpretativista, o que diferencia a ação (social) humana do movimento dos objetos físicos é o fato de a primeira ser inerentemente significativa. Segundo Schwandt (2006), para que uma determinada ação social seja entendida (p. ex., ensino), o investigador deve compreender o significado que constitui essa ação. Dizer que uma ação humana é significativa "é alegar que esta possui um certo conteúdo intencional que indica seu tipo de ação e/ou que o sentido de uma ação só pode ser compreendido a partir do sistema de significados ao qual pertence" (Ibid., p. 195). Dois conceitos se destacam nessa afirmativa, sistema de significados da ação humana e o contexto no qual esta se desenvolve.

Para os autores interpretativistas, as pessoas, os grupos e as organizações estão envolvidos em um universo simbólico capaz de integrar um conjunto de significados, atribuindo-lhes consistência, justificativa, legitimidade; em outras palavras, o universo simbólico possibilita aos membros integrantes de um grupo uma forma consensual de apreender a realidade, integrando os significados e viabilizando a comunicação. Nessa perspectiva, "os valores socialmente compartilhados pelos indivíduos (intersubjetividade) na interpretação da realidade são a base para a análise organizacional” (SCHROEDER, 2009, p. 38).

Esse paradigma de análise organizacional que interpreta a ação de agentes em contextos de interação pauta-se em uma concepção dialética de mundo.

A dialética tem suas bases em Hegel (2003), em sua visão de um mundo pluralista. Na concepção dialética, o mundo está em contínuo estado de mudança e não existem arranjos permanentes, são padrões temporários e arbitrários e que devem ser considerados como uma entre muitas possibilidades de arranjos possíveis.

Para Benson (apud LOEBEL, 2005) desenvolver uma análise dialética implica em observar as transformações dos arranjos sociais em novas combinações envolvendo a busca por princípios fundamentais que respondem pelo aparecimento e dissolução de ordens sociais específicas. Uma análise dialética, segundo Benson, deve ser conduzida observando-se quatro princípios básicos: construção e produção social, totalidade, contradição e práxis.

$\mathrm{Na}$ construção e produção social pessoas produzem o mundo social e são, por sua vez, produzidas por ele. $\mathrm{Na}$ totalidade os fenômenos sociais devem ser estudados de forma 
relacional, observando-se a "inter-relação complexa e mútua pelos quais os componentes são construídos.

No processo de construção social encontram-se contradições, rupturas e inconsistências na vida social. Segundo Benson (apud LOEBEL, 2005, p. 25),

[...] as contradições sociais têm importantes efeitos sobre a produção. (1) Elas podem ocasionar deslocamentos e crises que ativam a procura por arranjos sociais alternativos; (2) elas podem se combinar de modo a facilitar ou de modo a dificultar mobilização social; (3) elas podem definir os limites da mudança dentro de um período particular ou dentro de um sistema determinado. A consciência destes limites pode permitir a última negação dos limites; mas no ínterim as contradições podem estar influindo bastante.

A práxis, nesta perspectiva, implica em um processo social e pessoal de permanente busca por mudança, o que implica na reconstrução livre e criativa dos arranjos sociais. Segundo Benson (apud LOEBEL, 2005, p. 25),

O compromisso da práxis é duplo, descritivo - isto é, daquelas pessoas que sob algumas circunstâncias podem se tornar agentes ativos reconstruindo suas próprias relações sociais e em última instância elas mesmas com base em análise racional - e ético - isto é, que as Ciências Sociais deveriam contribuir para o processo de reconstrução, para a liberação de potencial humano pela produção de formações sociais novas.

Do exposto emergem duas tendências intelectuais nos quais esta pesquisa se fundamenta: a) a imagem processual da sociedade, a percepção da sociedade em movimento e b) o não tratamento da sociedade (grupo, organização) como um objeto, isto é, a des-reificação da realidade social (SZTOMPKA, 2005).

Assim, utilizando-se os paradigmas organizacionais interpretativista e funcionalista e a perspectiva dialética de análise, acredita-se ser capaz de retratar, de maneira dinâmica, a realidade complexa da universidade, valorizando-se as pessoas, buscando encontrar significados em suas ações sem, porém, desconsiderar a estrutura social na qual estão imersas.

Na sequência a pesquisa é caracterizada.

\subsection{Delineamento da Pesquisa}


Este estudo pode ser caracterizado como qualitativo (do tipo fenomenológico), pois pretende utilizar uma série de técnicas interpretativas que procurarão “[...] descrever, decodificar, traduzir e entender o significado de certos fenômenos" que ocorreram com relativa naturalidade em uma organização" (COLLIS e HUSSEY, 2005, p. 145). Pode também ser considerado um estudo analítico com vistas à geração de um esquema de análise interpretativo/explicativo.

A estratégia orientadora da pesquisa pode ser identificada como explanatória, segundo a classificação de Collis e Hussey (2005), na qual a teoria existente é usada para entender e explicar o que está acontecendo. Mas, também possui características de estudo exploratório, segundo Gil (1994), por proporcionar uma maior flexibilidade na busca de informações sobre um determinado problema de investigação, com vistas a torná-lo mais claro, seja na construção de novas hipóteses, seja no aprimoramento de idéias sobre o tema.

A utilização do método qualitativo e do estudo explanatório/exploratório visa valorizar o estabelecimento de relações e articulações no fenômeno estudado, em uma perspectiva multinível, visando a uma melhor compreensão do objeto de estudo, esclarecendo seus conceitos e possibilitando discernir outros aspectos ainda não investigados e capazes de ampliar sua análise.

Outra estratégia metodológica utilizada foi o estudo de caso, caracterizado como um exame extensivo de um único exemplo de um fenômeno de interesse. Eisenhardt (1989) "refere-se ao estudo de caso como um estudo de pesquisa que foca no entendimento da dinâmica presente dentro de um único ambiente" (apud COLLIS e HUSSEY, 2005, p.73). Uma característica do estudo de caso identificada por Yin (2005) e que pode ser relacionada ao presente estudo é que o objetivo da pesquisa não será somente explorar certos fenômenos, mas também entendê-los num determinado contexto. Nesta linha de argumentação seguiu Pettigrew (1992) ao comentar aspectos de pesquisas sobre processo estratégico em instituições:

Aspectos metodológicos para esse tipo de pesquisa: 1) imbricamento; 2) ligação temporal (estudar o processo no passado, presente e futuro; 3) interação (implica a procura pela explicação das relações entre contexto e ação); 4) não-linearidade; 5) Alinhamento (a pesquisa deve associar o processo de análise da situação e explicação aos resultados esperados e/ou obtidos) (apud BULGACOV, 2007, p. 87). 
A opção por um período de tempo ampliado da unidade de análise, que não chega a caracterizar uma pesquisa de caráter longitudinal, mas resulta em um corte transversal ampliado, também segue a visão do mesmo autor ao argumentar que:

\begin{abstract}
Os pesquisadores precisam ser mais analíticos e explícitos nas pesquisas de processo estratégico, que o processo precisa ser estudado juntamente com o conteúdo e o contexto._O contexto, por sua vez, precisa ser sempre considerado no delineamento das pesquisas. Nesse sentido, métodos e abordagens de pesquisa precisam ser aperfeiçoados para tornar possível o estudo das variáveis e o papel do contexto no aperfeiçoamento gerencial dos processos, de modo geral. O autor exemplifica salientando que estudos longitudinais mais extensos podem auxiliar na demonstração da interrelação dinâmica das ações tomadas, dos processos utilizados e dos resultados alcançados (Ibid. , p. 110).
\end{abstract}

A preocupação em estruturar a pesquisa para observar processos organizacionais também aparece fundamentada em Van de Ven (1992), que faz as seguintes observações: a) a análise histórica é necessária para examinar uma série de questões no processo estratégico, porém, para evitar bias é ideal iniciar o estudo histórico antes do resultado do processo ser conhecido; b) o pesquisador deve estruturar cuidadosamente seus estudos de observação de forma consistente com sua definição e teoria de processo; c) deve-se buscar algum tipo de envolvimento entre o pesquisador e os participantes da pesquisa, as questões da pesquisa devem ser relevantes para estes. Por último, como síntese de suas reflexões, Van de Ven (1992) afirma que uma das questões mais importantes em pesquisa sobre processo estratégico é definir o significado de processo, isso implica que não se quer apenas descrever a ocorrência de um fenômeno, mas também explicar sua forma e por que ele ocorre.

Sobre estudo de caso deve-se destacar ainda uma questão. Em função da complexidade e do tempo que uma pesquisa com essas características demanda do pesquisador, em comum acordo com o orientador da tese, optou-se pelo estudo de um único caso, que apresentava características semelhantes às definidas por Van de Ven: o processo estratégico ainda estava em desenvolvimento, era possível por meio de documentos e entrevistas resgatar os eventos relevantes do processo, a percepção e os sentimentos dos atores e havia disposição e interesse dos gestores e professores da unidade em participar da pesquisa e contribuir para a compreensão do fenômeno analisado e com o objeto de estudo da tese.

Um aspecto metodológico importante não apenas na coleta e análise dos dados, como também para a própria elaboração de um esquema de análise do processo estratégico em universidades, é o relacionado com a abordagem multinível. 
O referencial teórico utilizado para fundamentar a tese e as observações e as reflexões feitas pelo autor quando da realização das entrevistas e análise documental do caso em estudo fundamentaram a convicção, comungada com Wilson e Jarzabkowski (2004), de que para orientar pesquisas sobre o processo e o fazer estratégico há necessidade de se estabelecer uma visão relacional entre os níveis micro-social e macro. "Nessa visão relacional, macro e micro constituem dois pólos de um contínuo que coexistem em uma tensão relacional. O relacionamento entre esses dois pólos é bidirecionado, de modo que qualquer atividade que ocorra esteja relacionada tanto ao contexto mais macro quanto ao mais micro (WILSON e JARZABKOWSKI, 2004, p. 15). A figura 5 demonstra essa visão relacional.

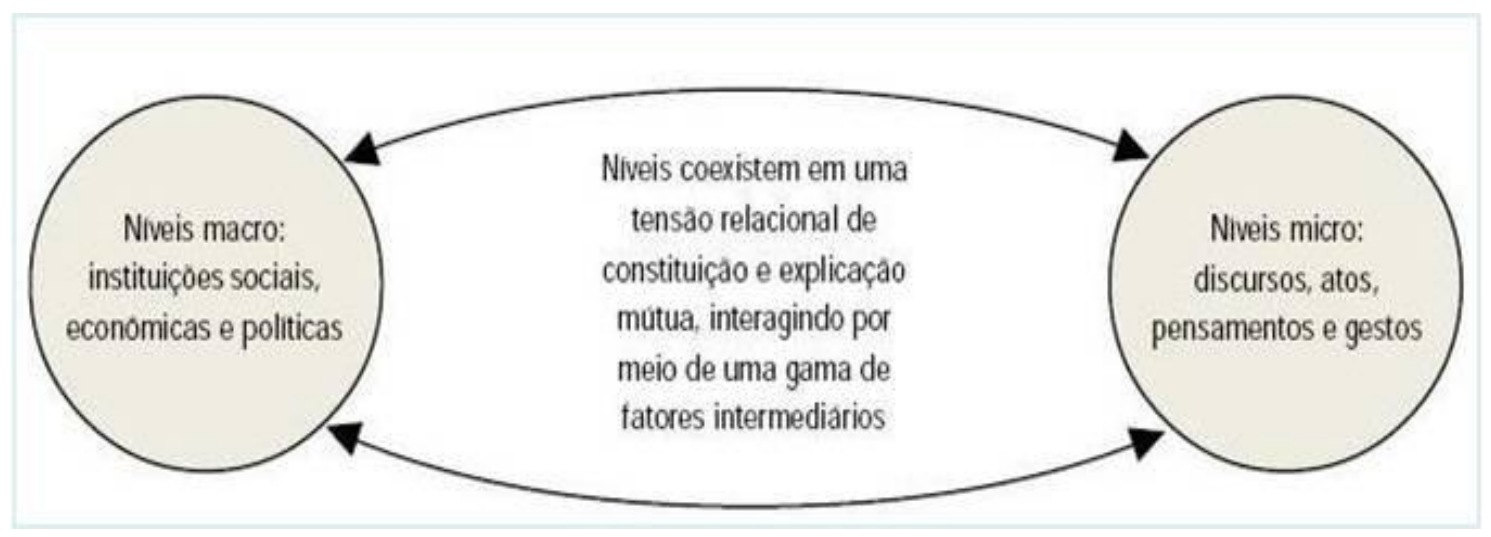

Figura 5 - Visão Relacional Macro e Micro Fonte: WILSON; JARZABKOWSKI, 2004, p. 16.

Essa visão relacional, na opinião dos autores, cria formas de abordar o fenômeno da pesquisa de maneira muito mais dinâmica e complexa. O importante nessas relações ou interações é procurar explicar "como as macroinfluências são interpretadas e constituídas no nível micro, ou como as práticas no nível micro influenciam mais resultados no nível macro" (WILSON e JARZABKOWSKI, 2004, p. 16).

O universo e a amostra para o estudo de caso são explicitados abaixo.

\subsection{Universo da pesquisa}

A pesquisa desenvolveu-se na Universidade de São Paulo (USP), de forma específica, na Escola de Artes, Ciências e Humanidades (EACH). Os sujeitos da pesquisa foram um grupo 
de dirigentes e docentes em atuação na USP e na EACH, no período compreendido entre 2002 e 2010, sendo que alguns destes foram responsáveis por escolhas e decisões estratégicas dos eventos que compõem o fenômeno, enquanto outros participaram do processo.

Foi feita a opção por analisar dois eventos específicos, segundo o esquema analítico a ser elaborado: o processo de elaboração do projeto da EACH e o processo de elaboração do projeto do primeiro curso de mestrado na nova unidade.

\title{
3.4. Instrumentos de Coleta e Análise de Dados
}

Com relação aos dados, a pesquisa adotou predominantemente os de natureza qualitativa. As fontes de dados principais foram entrevistas com os principais dirigentes e alguns professores da instituição no período de análise definido, observação do funcionamento da unidade e análise de documentos diversos (livros, revistas, jornais etc.) que pudessem retratar a história da instituição e da unidade, principais eventos e processos organizacionais significativos.

A entrevista é uma excelente técnica para apreender como os membros de uma dada categoria social mantêm, transformam e desafiam uma ou várias identidades.

\begin{abstract}
A entrevista favorece o estudo de realidades sociais, cognitivas e simbólicas que ultrapassam, atravessam ou cortam as ancoragens locais. E também se mostra uma técnica adequada quando os entrevistados, pelas posições que ocupam, circulam entre diferentes mundos e locais de trabalho, possuindo uma mobilidade elevada. (Collins, apud MENDES, 2010, p. 9).
\end{abstract}

Em razão de adotar-se uma abordagem fenomenológica foi enfatizado, quando das entrevistas, a obtenção das definições dos participantes quanto às dimensões do esquema, às situações e aos eventos, "na tentativa de explorar as suas suposições, os seus significados implícitos e as regras tácitas" (CHARMAZ, 2009, p. 54).

Tanto para análise das entrevistas como da parte documental optou-se por não aplicar uma análise de conteúdo de contornos quantitativos. O objetivo, desde o início, não era saber quantas vezes se disse algo sobre algum tema, mas sim quem disse o quê, como e com que interesses. Procurou-se precisar os argumentos utilizados e, de forma concomitante, montar 
um mapa de eventos, uma descrição mais detalhada da situação e uma interpretação crítica a partir dos dados.

Como Mendes (2007), buscou-se verificar, por exemplo, que aliados foram mobilizados e que adversários foram identificados, quais os aspectos consensuais e aqueles sobre as quais se extremaram as posições. Quais elementos do contexto histórico-social influenciaram e acentuaram certos componentes identitários e certos comportamentos, conduzindo ao abandono e esquecimento de outros e quais dimensões organizacionais, na visão dos entrevistados, interferiram nas ações empreendidas.

Da integração de todas as fases da pesquisa chegou-se ao modelo orientador da pesquisa.

\subsection{Modelo Orientador da Pesquisa}

De acordo com Van de Ven (2000, p. 143), “os modelos orientadores de pesquisa consistem em uma série de teorias, instrumentos, procedimentos, suposições e manipulações que são usados para aplicar os métodos científicos de observação e análise”. Trata-se, portanto, de um conjunto composto por elementos envolvendo a definição multilinear de um foco de pesquisa, discussão teórica, experiência empírica e elaboração teórica, na busca por avanços no conhecimento científico.

A figura 6 demonstra o relacionamento desses elementos ao longo do processo de elaboração da tese. 


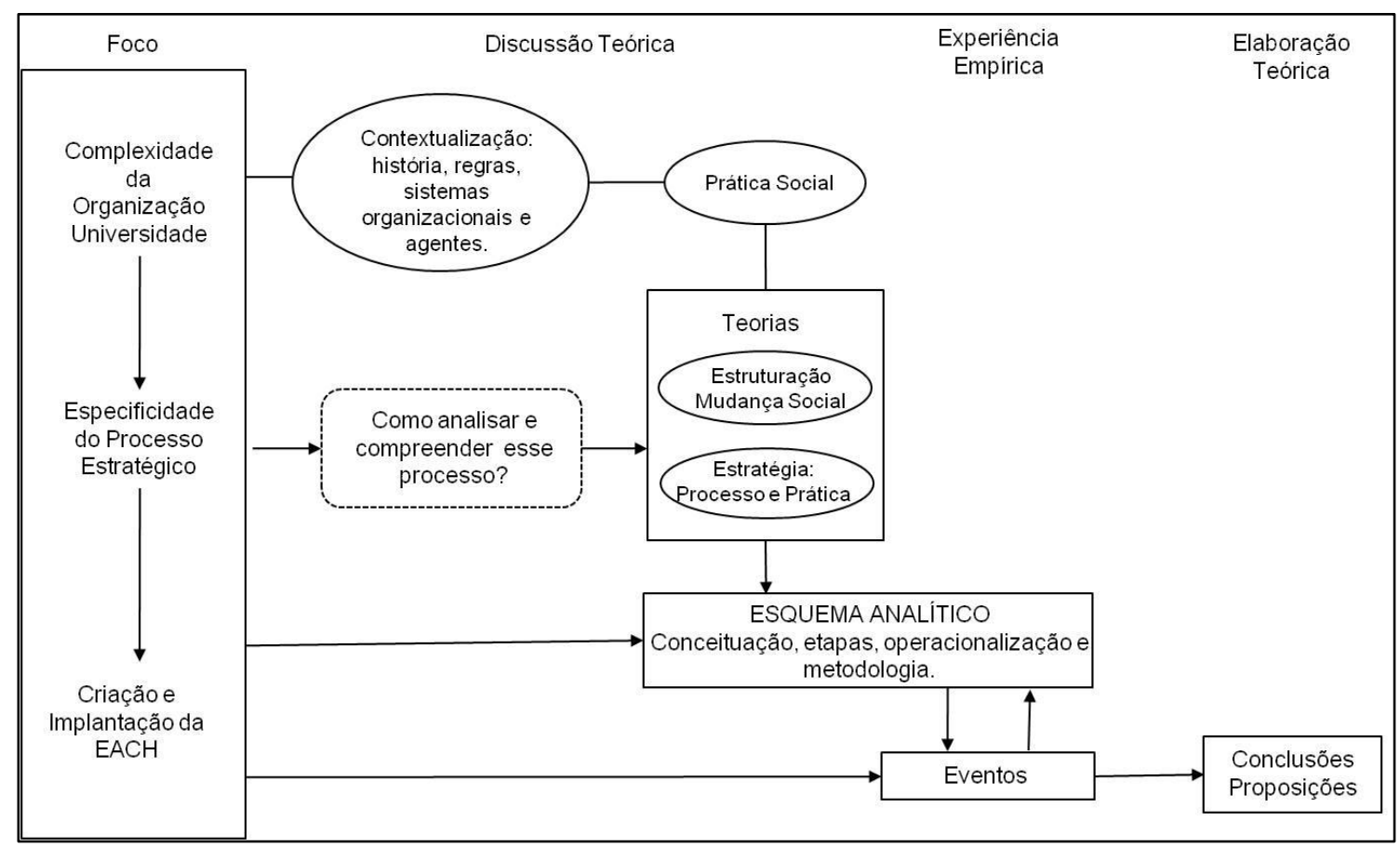

Figura 6 - Modelo Orientador da Pesquisa

\subsection{Limitações da Pesquisa}

Por se tratar de uma pesquisa em que se busca elaborar um esquema analítico para melhor interpretar e explicar como ocorre o processo de formulação e implementação de estratégias por meio de uma abordagem multiparadigmática e multinível, a partir de um processo ainda em andamento, em uma unidade recém-criada de uma universidade pública, a pesquisa apresenta algumas limitações.

Ao tentar por em evidência a existência de uma estrutura (um esquema), isto é, de mecanismos de relação entre as partes de um dado processo estratégico analisado, concebe-se que a pesquisa não possa repousar nem sobre uma tentativa de exaustividade, nem sobre uma vontade de representatividade. Baseia-se na aplicação de uma escolha intuitiva e progressiva de eventos que ao mesmo tempo permitem o estabelecimento de fronteiras e níveis de análise para a pesquisa que vão se aprofundando conforme a progressão da pesquisa, mas limitam a interpretação do pesquisador à realidade em que ocorrem esses eventos.

Concorda-se, entretanto, com Freidberg (1993, p. 249) de que essa escolha não é completamente arbitrária, mas guiada e controlada ao mesmo tempo por uma diligência iterativa, pela plausibilidade e pelo interesse dos seus resultados "e finalmente pelas 
retroações que ela permite por em evidência, o que a sujeita a um poderoso princípio de realidade”. Mas, por mais instruída e fechada que ela seja, nem por isso deixa de ser uma escolha que se baseia em uma questão de pesquisa e que, evidentemente, orienta o resultado.

Ao mesmo tempo, o resultado da análise está historicamente situado. Atores, sistemas organizacionais e contextos em que ocorrem os eventos são construídos e percebidos a partir de uma ação interativa e sua descrição não pode pretender esgotar a realidade e nem proporlhe uma fórmula prescritiva.

É importante ressaltar também, que embora seja necessário apresentar e discutir os princípios pedagógicos envolvidos na criação e implantação da EACH - por acreditar na interdependência entre conteúdo e processo estratégico - o aspecto pedagógico não será absolutamente o foco da pesquisa. Como pode ser observado na discussão do problema e dos objetivos do trabalho, o foco é efetivamente buscar interpretar e explicar como ocorre o processo estratégico. Isto, sem dúvida, impede uma análise mais acurada dos efeitos e resultados do projeto do ponto de vista educacional, mas não impede que sejam elaboradas proposições (não prescrições) à USP, a partir das conclusões da pesquisa, sobre formas de melhor conduzí-lo.

Além disso, esta pesquisa está abrangendo apenas a elaboração e a fase inicial de implementação do Projeto $\mathrm{EACH}$, sendo necessária a continuidade da pesquisa em outros momentos para obter uma visão mais explicativa do fenômeno, utilizando-se, inclusive, de aperfeiçoamentos no esquema proposto e aplicando teorias e metodologias diversas. 


\section{ESQUEMA ANALÍTICO}

Neste capítulo, apresenta-se a proposta do esquema analítico. Foi elaborada a partir da fundamentação teórica e da observação e análise do processo estratégico ocorrido quando do episódio da criação e implantação da EACH.

Para a exposição do esquema considerou-se relevante elaborar, primeiramente, algumas considerações gerais em que são salientados aspectos complementares ao conceito de evento, já abordado no capítulo 2. Em seguida, apresentam-se a identificação e conceituação das principais dimensões, a dinâmica de funcionamento e a visão geral do esquema. Finaliza-se com uma proposta de operacionalização em pesquisas organizacionais.

\subsection{Considerações Gerais}

Um esquema analítico é uma estrutura composta de dimensões entre as quais existem relações. Cada dimensão comporta variáveis que ainda não estão particularizadas para uma utilização em um contexto específico. O esquema permanece impreciso quanto a seu modo de emprego e à consideração das restrições de ordem.

Ao realizarem estudos sobre processos decisórios Bell et al (1988) definiram três categorias de modelos teóricos e pragmáticos: normativo, descritivo e prescritivo. Dos três, o descritivo é o que melhor se encaixa na perspectiva da tese, e apesar do esquema a ser proposto não ser sobre processo decisório, sua definição esclarece de forma sucinta o que se busca compreender.

Esquemas (modelos) descritivos, para os autores citados, procuram mostrar como, na vida real, pessoas reais, em organizações, decidem e implementam estratégias. Procuram mostrar como, de fato, as pessoas e grupos acumulam informações sobre o ambiente, como resolvem ambigüidades, como acordam sobre objetivos, como buscam implementar decisões, por exemplo. 
Ao detalhar o processo de elaboração do esquema, pode-se, inicialmente, realizar a seguinte síntese em relação aos fundamentos teóricos apresentados até aqui. Realiza-se uma abordagem de prática social que estuda a construção social da realidade a partir da dualidade entre estrutura e ação. Busca-se apreender as contradições dialéticas geradas pela interação dos agentes, em eventos delimitados, imersos em uma realidade histórica, social e cultural que guia os seus processos interpretativos e que são mediadas por regras e recursos de uma organização específica, podendo resultar em mudanças organizacionais e sociais.

Como já afirmaram Vasconcellos et al (2004), o objetivo é apreender as categorias sociais relevantes, reconstruir as experiências dos atores e os significados socialmente construídos, detectar as regularidades, para se chegar a uma interpretação possível sobre o fato estudado. Destaque-se que a regularidade ocorre na medida em que há compartilhamento de sentido (significado) entre agentes relativamente às estruturas e espaços de ação e recorrência de valores, crenças e interesses (motivações) entre esses mesmos agentes (MEIRELLES, 2003).

Parte-se do pressuposto que as estruturas sociais restringem, delimitam e permitem a ação ordenada, ao mesmo tempo em que são reafirmadas e produzidas no processo interativo e intersubjetivo de grupos constituídos no interior das organizações, em busca de seus interesses individuais e coletivos. Padrões culturais e sociais podem surgir destas interações e tornar-se institucionalizados ou não, dependendo das forças políticas participantes e do grau de aceitação na organização das ações estratégicas empreendidas.

O sistema social em análise, a organização universitária, é composto por diversos grupos e estruturas interconectadas de forma mais ou menos autônomas. Esses grupos se submetem às regras, normas e padrões de comportamento gerais (contexto histórico, cultural e social, estrutura e cultura da organização), porém a partir de interpretações particulares, condicionadas por subculturas específicas com dinâmicas e padrões sociais próprios de atuação, gerando contradições no interior do sistema.

São essas contradições e inconsistências entre os diversos grupos de uma organização que geram a dialética propulsora da práxis social, no espaço onde ocorre a ação estratégica e no qual o processo estratégico tem seu núcleo motriz. A estratégia desdobra-se em um conjunto de eventos que geram outros eventos e que, retrospectivamente, constituem um fenômeno específico de análise. 
Após analisar o conceito de evento em Giddens (2003) e Van de Ven e Poole (1995) é possível afirmar que evento é um conceito multifacetado e cujo significado depende do nível social (macro, meso ou micro) no qual está sendo utilizado para análise de um determinado fenômeno. Em Giddens (2003), que o denomina como episódio, é caracterizado como acontecimento que marca uma ruptura de uma tradição e que gera mudança radical. A abordagem do sociólogo é macro e os episódios referem-se às mudanças que ocorrem apenas de tempos em tempos nas sociedades.

Em Van de Ven e Poole (1995), os eventos compõem com atividades e decisões uma sequência que ocorre durante um determinado fenômeno central, em um período histórico definido, em uma dada organização, que resultam em uma dada trajetória, conforme demonstrado anteriormente pela figura 5 .

Segundo Strauss (apud ELKJAER, 2001, p. 110), trajetória é:

O curso de qualquer fenômeno experienciado, tal como evolui no tempo (um projeto de engenharia, uma doença crônica, uma revolução social etc.); [...] As ações e interações que contribuem para sua evolução. Ou seja, os fenômenos não se desenrolam exatamente de forma automática, nem são diretamente determinados por circunstâncias sociais, econômicas, culturais ou outras; ao contrário, são em parte formados pelas interações dos atores interessados.

Da forma como foram utilizados na construção do esquema analítico os conceitos podem ser representados pela figura 7 : 


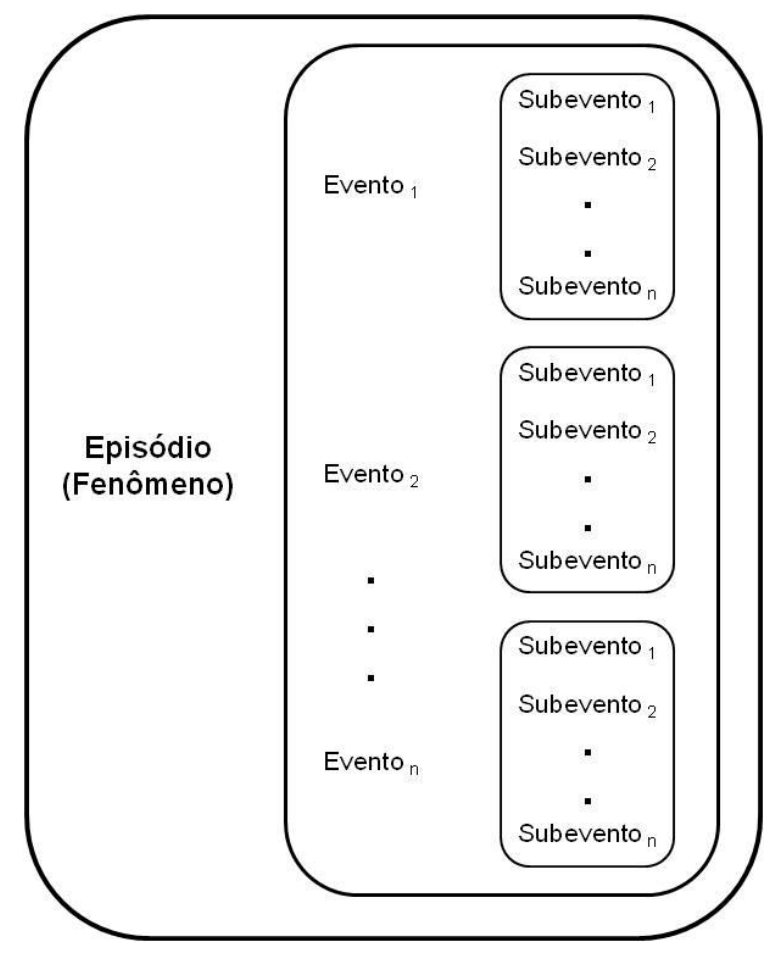

Figura 7 - Trajetória de um Episódio

Um determinado episódio é constituído por uma série de eventos, sendo que cada evento também é constituído por outro conjunto de subeventos.

Ressalte-se ainda, que um evento é um momento de mudança no qual ação e estrutura se encontram. Para Abrams, os eventos “[...] constituem conjunções decisivas de ação e estrutura; são momentos transparentes de estruturação nos quais a atividade humana encontra possibilidade social e pode ser vista com clareza como simultaneamente determinada e determinante" (apud SZTOMPKA, 2005, p. 354).

Por fim, os agentes também definem a ocorrência de um evento, pois, segundo Zarifian (2009), um evento ocorre,

uma vez que um acontecimento aleatório provoca sentido para os sujeitos humanos, sentido esse que faz com que esses sujeitos: a) atribuam importância a esse acontecimento aleatório, b) sintamse interessados por aquilo que é produzido pela ocorrência desse evento aleatório, c) inscrevam-se no curso de seu pensamento, de seus intercâmbios lingüísticos, de sua ação, de modo que o torne seu, e d) aceitem assumir a responsabilidade até que uma resposta satisfatória tenha sido dada ao acontecimento (ZARIFIAN, 2009, p. 160). 
O autor salienta que dois processos de subjetivação se constroem quando do desenvolvimento de um evento, sendo a seguir destacado o segundo, em razão de sua relação mais próxima com a abordagem da tese. Assim, desenvolve-se,

um processo pelo qual o acontecimento aleatório será "compartilhado", quanto a seus efeitos potenciais e suas significações e, então, inserido em um espaço intersubjetivo de comunicação, que condicionará os pensamentos e as ações que um coletivo de trabalho desenvolverá, e, face daquilo que se tornará, para ele, um mesmo evento (ZARIFIAN, 2009, p. 161, grifo nosso).

Outro aspecto a ser destacado nestas considerações gerais sobre o esquema analítico é a questão do tempo e da história. Estruturas e ações foram constituídas e estão imersas em contextos históricos, sociais e culturais que traduzem a especificidade da organização e também fornecem parte dos parâmetros interpretativos e formas de ação aos agentes que resultam em práxis.

Segundo Norbert Elias, as sociedades estão rigorosamente situadas no tempo histórico: qualquer sociedade atual é proveniente de sociedades precedentes e aponta além de si mesma para uma diversidade de possíveis futuros. Esse processo é basicamente não planejado, embora abrigue episódios longos ou curtos de mudança social planejada, intencional. "Mas não há nenhum automatismo ou inevitabilidade na mudança; o processo é totalmente contingente, ativado por seres humanos em suas variadas e complexas relações" (SZTOMPKA, 2003, p. 352).

Esses agentes, em suas diferentes posições na estrutura social, possuem diferentes níveis de capacidades, conhecimento, experiência e interesses, ocasionando formas distintas de compreender e agir no mundo e de realizar a mudança social.

Ao se propor uma análise do processo estratégico na qual são elencadas três dimensões (agentes, contexto e sistemas organizacionais) interdependentes quando da ação estratégica, pretende-se realizar uma análise não-determinística de eventos que constituem um dado episódio (fenômeno), no sentido de captar a singularidade de um caso específico.

A pesquisa empírica empreendida na tese parte dessa fundamentação para procurar responder as questões de pesquisa formuladas na introdução e que podem ser assim sintetizadas: quem são os agentes estratégicos, como eles tomam as decisões que podem levar às ações, de que 
forma essas ações se formam, como a combinação entre agentes, contexto e sistemas organizacionais mobilizam, potencializam ou restringem essas ações, que motivações e interesses ficam demonstrados pelos agentes, que jogos políticos ficam evidentes, quais as práticas reconhecidas nas ações estudadas, ou seja, como são formuladas e implementadas as estratégias.

Procura-se também, no estudo empírico, fundamentado nas perspectivas de processo e de prática, estabelecer vínculos com os modelos organizacionais focados na estrutura e na tomada de decisão em universidades e com as práticas empreendidas pelos estrategistas.

Apresentam-se, na sequência, as três dimensões centrais do esquema analítico proposto; contexto histórico, social e cultural, agentes e sistemas organizacionais - que constituem o núcleo motriz-estrutural do processo estratégico - a dinâmica de funcionamento e a visão geral.

\subsection{Esquema Analítico: Dimensões, Conceitos, Dinâmica e Visão Geral}

Uma representação estática das três principais dimensões do esquema analítico é demonstrada pela fig. 8.

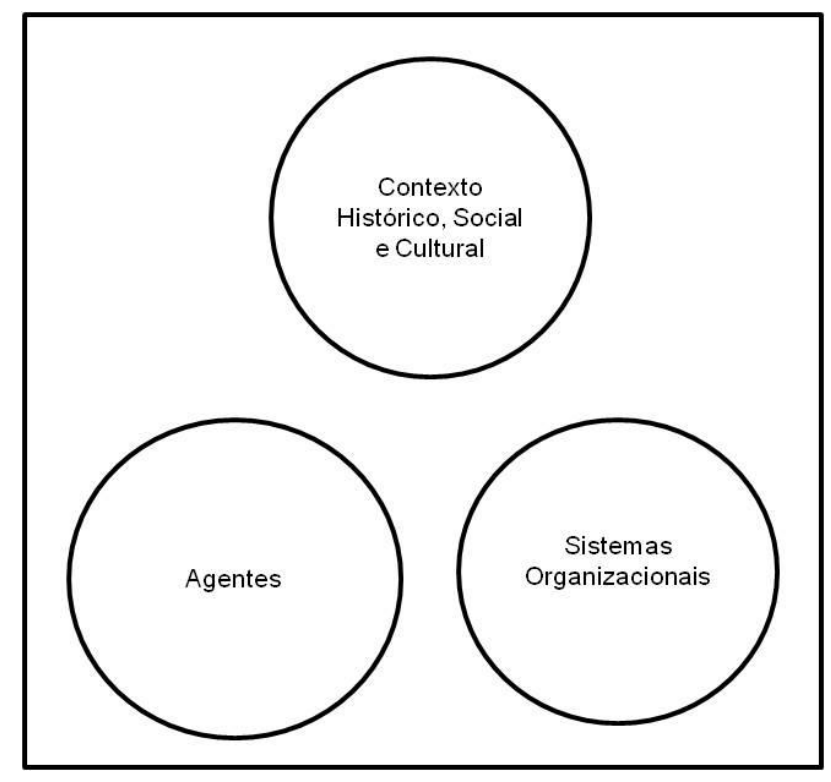

Figura 8 - Dimensões do Esquema 
Não se pode pensar em organizações independentes do contexto em que estão inseridas. Isso significa que as organizações devem ser compreendidas dentro de um espaço social e de um tempo específicos, constituindo o que se denomina de contexto histórico, social e cultural. $\mathrm{O}$ histórico, o social e o cultural estão intrinsecamente ligados, pois não existem relações sociais entre os indivíduos e os grupos nem entre estes e os objetos sociais que se dêem sem referência a um tempo e a um espaço. Toda significação só pode, então, ser compreendida numa prática e num pensamento da sociedade, de cultura e da história (FREITAS, 2000, p. 7).

O contexto histórico, social e cultural está situado ao nível das totalidades sociais abstratas de Sztompka (2005) e representa a realidade social no passado e no presente e sinaliza aspectos do futuro. É interpretado no esquema analítico como constituído por estruturas externas, sendo formador/influenciador de estruturas internas à organização. Estas estruturas são representadas por regras normativas, culturais e simbólicas, normalmente conceituadas como institucionais. Contém elementos da história na qual uma organização foi se formando e que acabam por emergir quando dos processos de interpretação dos agentes envolvidos em uma dada ação estratégica.

No campo subjetivo são propriedades de um setor organizacional ou de uma organização e não de indivíduos ou grupos localizados. Essas propriedades apresentam um baixo nível de conscientização por parte dos agentes. Indicam formas de se comportar e de fazer as coisas para que sejam aceitas e legitimadas pela maioria.

No campo objetivo, o contexto se concretiza por meio de normas, leis, resoluções etc., mas também se encontra nos discursos legitimados, ferramentas, modos de proceder ditos como certos situados no setor social em que a organização está inserida e que passam a constituir um sistema de crenças que pode de algum modo restringir, mas também potencializar as ações empreendidas pelos diversos grupos (WHITTINGTON, 2004).

Deve-se ressaltar um diferencial da proposta do esquema. O contexto externo e o interno à organização, apesar de inicialmente serem caracterizados em separado, se mesclam ao longo do processo de análise de uma ação estratégica e, a partir daí, suas fronteiras somente podem ser demarcadas se observados dissociados dessa ação. 
Os fatos relacionados ao contexto devem ser demarcados no passado e no presente. Em razão da amplitude de eventos que constituem a história de um setor organizacional e de uma organização específica há necessidade de se limitar a análise. Quando da abordagem histórica o que se busca, prioritariamente, são os eventos passados que implicaram em mudanças ou que resultaram em regras e práticas institucionalizadas. A proposta de criação de uma nova organização, uma reforma legal, mudanças nas políticas de governo, ou de forma mais localizada, na estrutura da organização, projetos de reorganização internos, por exemplo.

No tempo presente, percebe-se que um determinado evento emerge a partir de forças contextuais específicas. Não são aspectos gerais de um ambiente econômico ou social, mas fatos relevantes que, na interpretação dos agentes, participam diretamente no desenvolvimento de um determinado evento. Uma crise que desencadeia pressões sociais, uma oportunidade originada pela elaboração de um projeto inovador, a possibilidade de um grupo social fortalecer sua legitimidade, são fatos que podem servir como exemplos.

A dimensão de sistemas organizacionais, que corresponde ao nível das estruturas (regras e recursos) internas à organização, é dividida no esquema em duas partes: a) as regras (estrutura organizacional, cultura organizacional, estruturas não-formais e subculturas) e; b) os recursos (gestão de pessoas, gestão estratégica, liderança, jogos de poder, uso de tecnologia, processos decisórios, processos de influência e coordenação, por exemplo).

As regras possuem estabilidade maior e os agentes devem procurar ajustar suas ações a elas. Essa estabilidade porém é relativa, em razão dos processos dialéticos existentes no interior da organização. A estrutura e a cultura da organização consolidadas ou institucionalizadas são confrontadas a todo o momento por estruturas não-formais e por culturas emergentes formadas a partir da constituição quase que permanente de grupos que acabam por constituírem subculturas.

Os recursos implicam em processos, transformação, desenvolvimento, conduta e atividades que mesmo constituindo a estrutura organizacional estão mais próximos da interferência dos agentes (grupos) que os utilizam na modificação ou permanência das regras estruturais quando os mobilizam na ação. 
Eles podem ser representados pelos processos decisórios, comportamento gerencial, liderança, comportamento administrativo, processo de influência e coordenação (BASTOS, 2009, p. 95), mas também, pelos processos mais ordenados de gestão de pessoas, gestão estratégica e uso de tecnologia, conforme destacado anteriormente, e que traduzem uma espécie de competência organizacional.

Os agentes - que correspondem ao nível das individualidades no modelo de Sztompka (2005) - é a dimensão constituída por indivíduos e membros de coletividades concretas (grupos, associações etc.). O plural do conceito significa que a abordagem do esquema se dará, predominantemente, ao nível dos grupos ou dos agentes interligados.

No nível dos agentes, as ações têm por base suas idéias, pensamentos e crenças. Atuam a partir de sua cognoscitividade (saber jogar o jogo, usar o discurso, persuadir, ganhar apoios) quando motivados ou interessados por algo (definir uma identidade, encontrar um lugar, ser reconhecido). O que os diferenciam são suas capacidades ou recursos individuais (criatividade, inovação, experiência etc.).

Em função do foco da pesquisa, o processo estratégico, os agentes são os que participam não apenas de uma ação estratégica, mas que estão numa posição de definir a sua direção. Normalmente são os gestores de nível superior e médio. $\mathrm{Na}$ universidade, porém, diagnosticaram-se eventos coordenados diretamente por docentes, com pouca interferência dos gestores.

Há necessidade agora de integrar essas dimensões. O contexto histórico, social e cultural e as estruturas organizacionais de alguma forma restringem o espaço de interpretação e de ação dos agentes em uma situação específica capaz de gerar uma ação estratégica. Porém, ao mesmo tempo, os agentes não se limitam a responder às demandas contextuais e acatar as regras estruturais, possuindo diferentes graus de autonomia que podem se ampliar em determinados eventos quando, ao constituírem um grupo, os agentes adquirem mais poder e mobilizam recursos capazes de influenciar no desenvolvimento da organização.

A figura 9 representa o ponto de interseção entre as dimensões do esquema. 


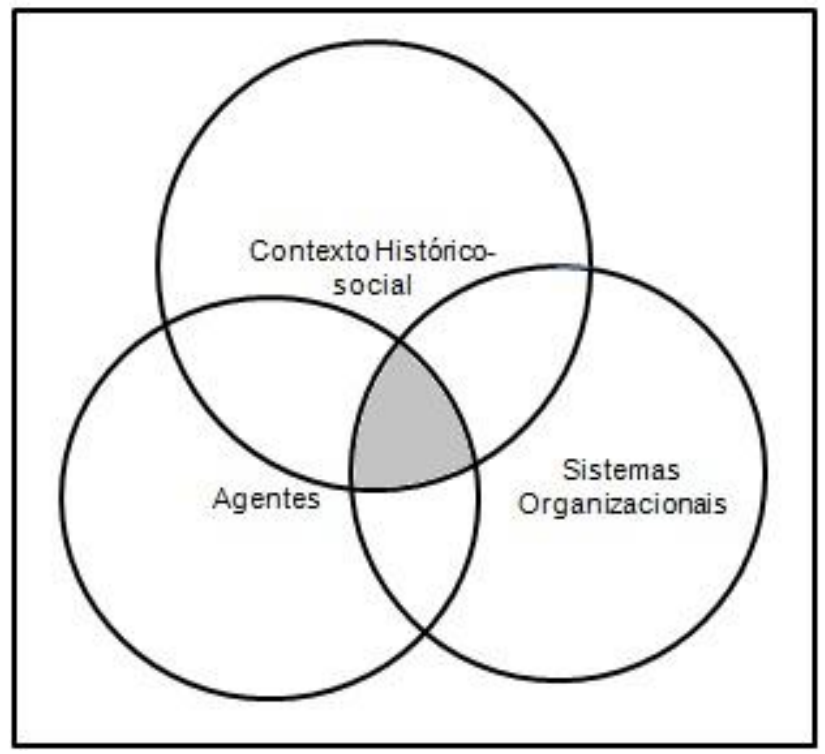

Figura 9 - Interseção das dimensões do esquema

Trata-se agora de empreender uma tentativa de "conceituar como certas propriedades das estruturas e certas propriedades das pessoas se combinam efetivamente na interface (Archer, apud Sztompka, 2005, p. 367). Archer se propõe a examinar a sua interação, seu mútuo intercâmbio, em lugar de fundi-los como estreitamente constitutivos um do outro (como em Giddens, 2003), porque "todo o problema do dualismo analítico consiste em ser capaz de investigar as relações entre elas" (Ibid, p. 367).

Parte-se do princípio da formação de um núcleo motriz-estrutural (SZTOMPKA, 2005) capaz de sintetizar a trama construída pelas experiências e relacionamentos que acontecem em contextos específicos, intermediados por estruturas organizacionais. Essa trama encontra a sua síntese nos eventos, componentes reais de como é feita a sociedade. Fazendo uma correlação com o tema da pesquisa, os eventos representam nesta abordagem teórica, as ações estratégicas constituintes de um determinado episódio em estudo, como, no caso da tese, a criação e implantação de uma nova unidade acadêmica.

Para que o evento (ação estratégica) ocorra, entretanto, não basta a interseção das dimensões, o núcleo precisa ser ativado, sendo necessário que os agentes queiram e possam atuar. Os agentes são sempre potencialidades que se mobilizam por meio da ação, no caso específico, da interação, uma ação produzida em conjunto, em que existem trocas e influências recíprocas e por meio da qual vão se consolidando formas de interpretação da realidade comuns 
(intersubjetividade) e mecanismos próprios de utilização dos recursos estruturais da organização.

Ou seja, apesar de restringirem a ação dos agentes, as estruturas organizacionais (regras e recursos) também sofrem a influência de determinadas ações transformadoras. Mais tarde, determinada prática pode ser aceita por uma maioria e resultar na modificação de padrões comportamentais e regras de conduta institucionalizados e na emergência de novos ou, ao contrário, ser essa nova prática rejeitada, não implicando em mudanças. De qualquer maneira, o processo que leva a um evento é em parte emergente e resultante da interação entre os agentes e da mobilização de recursos organizacionais em uma determinada situação.

Quando o núcleo motriz é acionado, ocorre a integração das dimensões do esquema em torno de um núcleo que resulta em "práxis". Práxis é o resultado da síntese dialética da ação empreendida pelos agentes ao mobilizarem regras e recursos organizacionais, a partir da interpretação do contexto histórico-social. É um conjunto de atividades que efetuam transformações e produções, é uma qualidade nova emergente, não redutível isoladamente a nenhuma das três dimensões. Ela é fruto de uma conjuntura.

A figura 10 representa esse núcleo motriz do esquema:

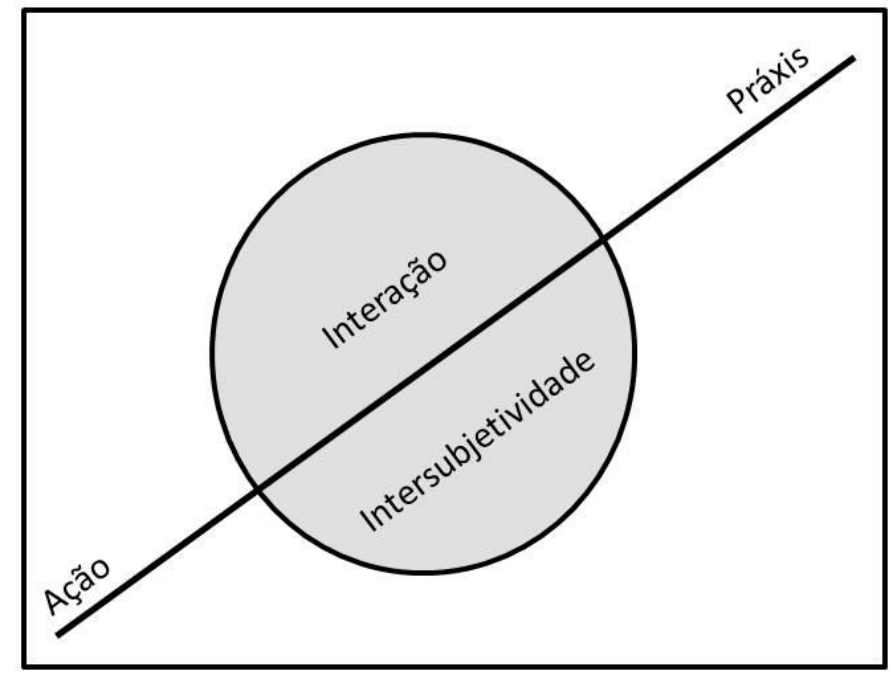

Figura 10 - Núcleo motriz-estrutural do esquema

Essa conjuntura representa a combinação da capacidade dos sistemas organizacionais operarem, das habilidades, conhecimentos e atitudes dos agentes envolvidos e do contexto 
mais específico em que se desenvolve um evento (ação estratégica). Nenhuma das três dimensões opera isoladamente, são complementares, operam por meio de uma dialética e o resultado é fruto de combinações que não podem ser previstas a priori. As 'potencialidades' das três dimensões quando juntas ou em combinação em um dado tempo e espaço sofrem transformações, daí os resultados de um evento nunca poderem ser plenamente previstos.

Deve-se ressaltar que o espaço criado pela interação não é apenas construído a partir da utilização de técnicas semelhantes de trabalho ou de mecanismos operacionais legitimados institucionalmente. É também, e principalmente, um espaço 'sociocêntrico', ou seja, quando sua construção de dá a partir do grupo e prevalece a oposição nós/os outros.

Bourdin citando Kevin Lynch (1976) reforça essa concepção ao afirmar:

Toda a espacialidade exprime a pertença a um nós, que se constrói e se manifesta em recortes territoriais. $\mathrm{O}$ espaço de pertença resulta do conjunto dos recortes que especificam a posição de um ator social e a inserção de seu grupo de pertença num lugar. $\mathrm{O}$ espaço de referências define o sistema de valores espaciais em que se inserem esses recortes e organiza a relação do aqui com o alhures (BOURDIN, 2001, p. 33).

Nesse espaço em que os indivíduos se encontram ocorre um compartilhamento intersubjetivo de idéias, valores e crenças e formas de comportamento. Ocorre também uma interação recursiva entre o domínio da ação dos grupos, o contexto e a organização. Nesse momento, mesmo sendo estas dimensões objetivamente diferenciadas, congregam-se em torno de um núcleo de ação estratégica, sendo que esta ação somente pode ser compreendida a partir da análise das diversas combinações entre essas dimensões que surgem no decorrer dessa ação.

Para que essa interação cooperativa entre os agentes se desenvolva estes devem: 1) estabelecer uma co-presença; 2) demonstrar atenção recíproca; 3) revelar responsividade mútua; 4) criar identidades funcionais congruentes; 5) construir um foco compartilhado e 6) divisar em algum momento um objetivo social (FINE, 2007, p. 268).

Destaque-se também, que o processo de 'eventuação' (ação estratégica) só pode ocorrer no tempo. Sztompka (2005) diferencia dois tipos de tempos: o externo (de transformação) e o interno (de funcionamento). O esquema da tese trabalha com o tempo de funcionamento de um fenômeno, no qual a mudança possui um ritmo próprio conduzido pelos agentes. O tempo de transformação, no qual as mudanças sociais são mais radicais e atingem as estruturas 
sociais (instituições) também pode ser analisado por meio do esquema, mas implicará em metodologia de pesquisa longitudinal.

A fig. 11 demonstra todos os elementos que compõe o núcleo motriz-estrutural do esquema e sua dinâmica.

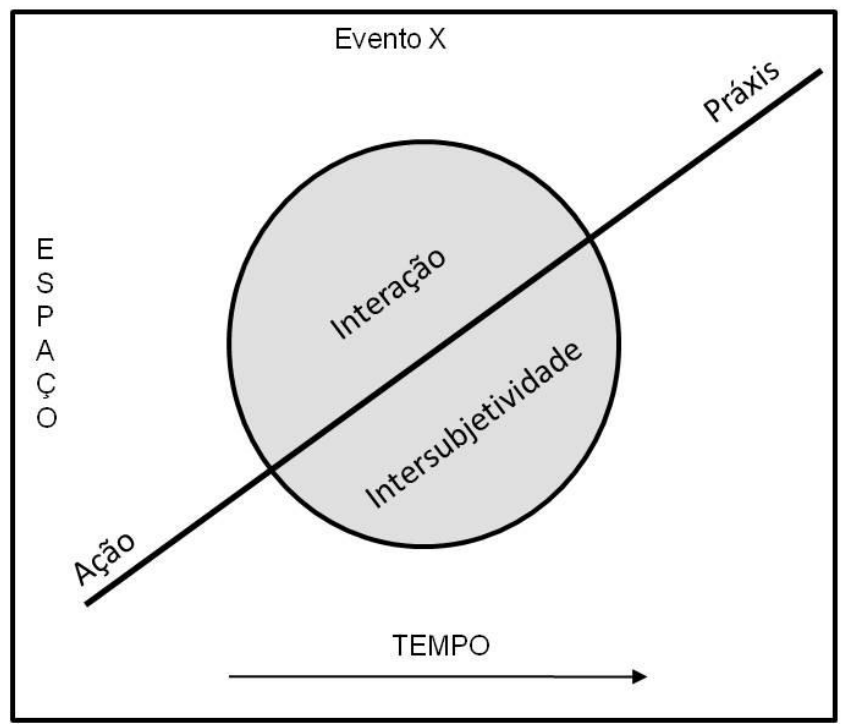

Figura 11 - "Eventuação"/Ação estratégica

A partir da apresentação desse núcleo motriz da ação estratégica é possível agora compor, utilizando a fundamentação teórica apresentada, uma visão geral das etapas do esquema proposto para a análise de um processo estratégico em uma universidade, visualizada na figura 12: 


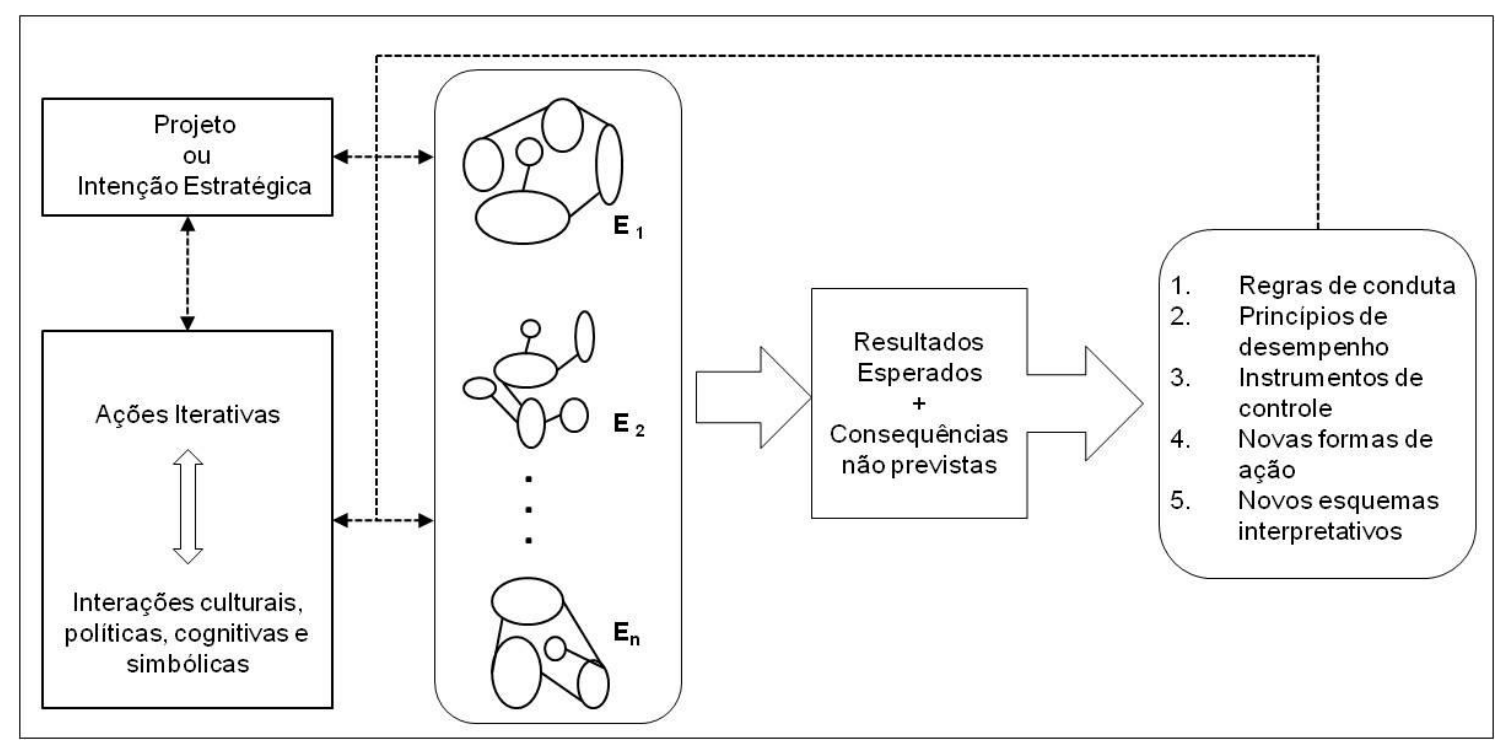

Figura 12 - Esquema Analítico: Visão Geral

Parte-se do princípio que um episódio pode surgir de um projeto com objetivos e metas detalhados ou, pelo menos, de intenções estratégicas declaradas em princípios e diretrizes.

Esse projeto mobiliza agentes em interações culturais, políticas, cognitivas e simbólicas. Essa mobilização gera várias ações estratégicas ou eventos (representados apenas visualmente pelos conjuntos de círculos) que, de forma em parte planejada, parte não, configuram uma dada trajetória para o processo estratégico.

Ao longo dessa trajetória são alcançados resultados/efeitos esperados, mas também não esperados que podem implicar em mudanças localizadas ou abrangentes, evidenciadas em uma universidade, por exemplo, em regras de conduta (mudança de comportamento dos agentes), em princípios de desempenho (novos critérios de avaliação), em instrumentos de acompanhamento e controle, em novas formas de ação e no surgimento, no longo prazo, de novos valores e crenças assumidos pelos grupos de uma organização.

É importante salientar que a visão linear do esquema é apenas didática, pois formulação e implementação de uma ação estratégica ocorrem muitas vezes de forma indissociada, sendo que, algumas vezes, uma determinada ação somente pode ser analisada como constituinte de uma estratégia retrospectivamente. Portanto, o início de um processo estratégico pode ocorrer em qualquer parte do esquema. 
Dessa forma o processo se auto-alimenta e um determinado evento possui a capacidade de alterar um projeto ou uma intenção inicial. Conforme Sztompka (2005, p. 382):

\begin{abstract}
Os eventos sociais, que fundem a operação estrutural e a ação propulsora (resultando em práxis) em um dado instante de tempo, influenciam tanto as estruturas (modificando ou conformando novas redes relacionais) quanto os agentes (modificando ou conformando suas capacidades imanentes) em um momento posterior. Como resultado, uma agência nova ou modificada aparece. O potencial da sociedade para a práxis foi alterado. A agência se manifesta, se e quando se concretiza na "eventuação", como uma nova práxis que por sua vez expressa a fusão da operação das novas estruturas com a ação dos novos agentes.
\end{abstract}

Em resumo, a visão geral do esquema demonstra a forma que assume o processo, permite estruturar as forças internas que o mobilizam, identifica os momentos de estabilidade e de mudança e ressalta os efeitos e resultados alcançados.

Ainda resta apresentar uma proposta de operacionalização do esquema em pesquisas.

\title{
4.3. Operacionalização do Esquema
}

Reforça-se a concepção de que um esquema analítico é uma estrutura composta de dimensões entre as quais existem relações. Cada dimensão comporta variáveis que ainda não estão particularizadas para uma utilização em um contexto específico. Em se tratando da abordagem metodológica da tese, essas variáveis serão especificadas a partir da percepção dos agentes sobre suas próprias ações, interpretadas pelo pesquisador a partir de entrevistas, documentos e observações.

Para obter essa interpretação, elabora-se uma entrevista semi-estruturada com o objetivo de obter a percepção dos agentes e os significados para eles de suas ações em um determinado evento, além dos fatores mediadores, sempre procurando relacionar essa interpretação ao fenômeno central em estudo, no caso, a criação e implantação da EACH.

Sugere-se como orientação para elaboração das questões das entrevistas e análise dos dados obtidos, a utilização de uma codificação baseada em conceitos. A partir da pesquisa empreendida e da construção teórica elaborada chegou-se aos constructos da pesquisa e suas definições conceituais e operacionais, demonstrados no quadro 7: 
Quadro 7 - Principais Constructos da Pesquisa

\begin{tabular}{|c|c|c|}
\hline Constructos & Definição Conceitual & Definição Operacional \\
\hline $\begin{array}{l}\text { Contexto histórico, social e } \\
\text { cultural }\end{array}$ & $\begin{array}{l}\text { É a trajetória histórica de uma } \\
\text { organização específica que pode } \\
\text { ter influenciado um determinado } \\
\text { evento. São também aspectos } \\
\text { sociais, como questões de } \\
\text { legitimidade no setor que } \\
\text { impactam } \\
\text { organização e determinada } \\
\text { percebidos pelos agentes como } \\
\text { influentes. }\end{array}$ & $\begin{array}{l}\text { Leitura de documentos, realização } \\
\text { de entrevistas com agentes, } \\
\text { observação de aspectos da cultura } \\
\text { organizacional objetivando, por } \\
\text { um lado, reconstruir a trajetória } \\
\text { da organização a partir dos } \\
\text { principais marcos institucionais e, } \\
\text { por outro, a identificação dos } \\
\text { fatores influentes do presente. }\end{array}$ \\
\hline Sistemas organizacionais & $\begin{array}{l}\text { São as regras e recursos da } \\
\text { organização. Inclui entre as } \\
\text { regras, a estrutura de poder e a } \\
\text { cultura da organização.. Entre os } \\
\text { recursos, a gestão estratégica, a } \\
\text { gestão de pessoas, a liderança, os } \\
\text { jogos de poder, o uso de } \\
\text { tecnologia etc. }\end{array}$ & $\begin{array}{l}\text { A partir da realização de } \\
\text { entrevistas com os agentes e } \\
\text { pesquisa documental identificar } \\
\text { ou intuir os sistemas da } \\
\text { organização que influenciam ou } \\
\text { são mobilizados por estes em um } \\
\text { determinado evento possibilitando } \\
\text { a sua emergência. }\end{array}$ \\
\hline Agentes & $\begin{array}{l}\text { Os indivíduos que participam } \\
\text { diretamente de um determinado } \\
\text { evento e que possuem poder para } \\
\text { influenciá-lo e modificá-lo. }\end{array}$ & $\begin{array}{l}\text { Caracterizar o perfil dos } \\
\text { indivíduos de um determinado } \\
\text { grupo a partir de relatos de suas } \\
\text { participações em determinado } \\
\text { evento e dos relatos de história de } \\
\text { vida. De forma mais específica: } \\
\text { buscar identificar se são criativos } \\
\text { e orientados para realizações, ou } \\
\text { passivos, conservadores e } \\
\text { tendentes à conciliação. Salientar } \\
\text { capacidades e competências } \\
\text { individuais. }\end{array}$ \\
\hline Ação & $\begin{array}{l}\text { São as atividades desenvolvidas } \\
\text { pelos agentes de forma rotineira. }\end{array}$ & $\begin{array}{lccc}\text { A partir } & \text { dos relatos } & \text { de } \\
\text { participação dos agentes em } & \text { em } \\
\text { determinado evento e } & \text { da } \\
\text { observação na organização } \\
\text { identificar rotinas, práticas e } \\
\text { mecanismos técnicos mobilizados } \\
\text { pelos atores em suas interações e } \\
\text { discursos do dia-a-dia. }\end{array}$ \\
\hline Interação & $\begin{array}{l}\text { Espaço e tempo onde ocorrem os } \\
\text { encontros face a face dos } \\
\text { indivíduos, onde trocam } \\
\text { informações e constroem o } \\
\text { sentido de suas ações. Formas de } \\
\text { relacionamento; Como ocorre a } \\
\text { aproximação entre os agentes; } \\
\text { Formas de comunicação; } \\
\text { Freqüência em que ocorre. }\end{array}$ & $\begin{array}{l}\text { Caracterizar os espaços em que } \\
\text { ocorrem as interações face a face } \\
\text { dos agentes participantes de um } \\
\text { evento. Por meio das entrevistas e } \\
\text { da observação identificar aspectos } \\
\text { comportamentais dos agentes nos } \\
\text { grupos (liberdade de se expressar, } \\
\text { possibilidade de correr riscos) e } \\
\text { os aspectos físicos desses } \\
\text { espaços. }\end{array}$ \\
\hline Intersubjetividade & $\begin{array}{l}\text { Idéias, valores e crenças } \\
\text { construídos na experiência } \\
\text { cotidiana e subjetiva pelos } \\
\text { indivíduos durante os processos } \\
\text { de interação. O que cria sentido. }\end{array}$ & $\begin{array}{l}\text { Por meio das entrevistas com os } \\
\text { agentes de determinado evento é } \\
\text { possível interpretar quais normas, } \\
\text { valores e regras orientam as } \\
\text { ações; } \\
\text { sentimentos/motivações/interesses } \\
\text { os agentes expressam de forma } \\
\text { comum. }\end{array}$ \\
\hline
\end{tabular}




\begin{tabular}{|c|c|c|}
\hline Núcleo Motriz & $\begin{array}{l}\text { Local onde as três dimensões } \\
\text { principais do esquema se } \\
\text { encontram e por meio da } \\
\text { interação e da intersubjetividade } \\
\text { constroem e dão sentido às ações } \\
\text { que resultam em práxis. }\end{array}$ & $\begin{array}{l}\text { Interpretação por parte do } \\
\text { pesquisador, fundamentado nas } \\
\text { entrevistas e nos dados } \\
\text { documentais, das combinações } \\
\text { entre as três dimensões que } \\
\text { constituem uma dada conjuntura. } \\
\text { Permite a reflexão sobre as } \\
\text { condições de emergência de certa } \\
\text { ação estratégica. }\end{array}$ \\
\hline Práxis & $\begin{array}{l}\text { Forma de agir resultante de uma } \\
\text { determinada conjuntura } \\
\text { constituída pelas características } \\
\text { de um determinado contexto, } \\
\text { sistemas organizacionais e } \\
\text { agentes em uma perspectiva } \\
\text { dialética. É o que constitui uma } \\
\text { ação estratégica ou um evento. }\end{array}$ & $\begin{array}{l}\text { Realização de entrevistas com } \\
\text { agentes participantes de um } \\
\text { processo. Interpretação por parte } \\
\text { do pesquisador dos efeitos } \\
\text { gerados com a implementação de } \\
\text { uma ação estratégica. }\end{array}$ \\
\hline
\end{tabular}

Sendo elaborado o esquema analítico e definidos os constructos, foi possível estruturar roteiros de questões para as entrevistas, em razão da cada evento, apresentados nos apêndices 1 e 2 .

Inicia-se a pesquisa a partir da definição de um episódio (fenômeno) e, seguindo as orientações de Van de Ven (1992), procura-se escolher um processo estratégico já iniciado, porém não finalizado. Procura-se fazer uma exploração inicial dos eventos que compõe o episódio escolhido para ser estudado.

Para tanto, o pesquisador pode realizar entrevistas exploratórias com os participantes do processo e leituras de documentos que relatam como este ocorreu. Ao mesmo tempo, pode tentar penetrar na organização por meio da participação em atividades, realizar visitas para observar o comportamento das pessoas, o uso dos espaços físicos etc.

Após esse primeiro momento é provável que já seja possível fazer um mapeamento inicial dos principais eventos envolvidos naquele episódio e que permitam elaborar uma trajetória inicial. Observe-se, porém, que outros eventos surgem ao longo da pesquisa e podem ser analisados dependendo do interesse do pesquisador e de seu julgamento sobre a relevância destes para o desenvolvimento do processo em estudo.

Feito esse mapeamento inicial, escolhe-se alguns desses eventos para uma análise mais aprofundada em que a matriz do esquema possa ser aplicada, assim como, teorias escolhidas para uma análise com foco mais específico. 
A partir desse momento, ou seja, da definição dos eventos que serão analisados, a operacionalização pode ser dividida em mais três etapas: (I) um momento descritivo geral de um dado evento, no qual se procura caracterizar o contexto, os agentes participantes e os sistemas organizacionais; (II) uma análise mais explicativa do evento, a partir das entrevistas e registros documentais, desenvolvendo interpretações de combinações ocorridas no núcleo motriz-estrutural e procurando compor a visão geral do esquema; (III) o uso de abordagens de estratégia como processo e como prática visando obter uma "lente" analítica complementar.

Ressalte-se que um fenômeno completo pode ser analisado segundo o esquema, mas também cada evento escolhido e seus subeventos, desde que as três dimensões do núcleo motriz possam ser identificadas.

É apresentado na sequência, o detalhamento das etapas sugeridas para a operacionalização do esquema. $\mathrm{Na}$ realidade, deve-se ressaltar que esta divisão é didática, pois quando da realização das análises dos dados percebeu-se que as etapas se interpenetram. Porém, optou-se por apresentar dessa forma em razão de clareza e melhor compreensão de todo o processo.

\section{$1^{\circ}$. Passo: Definição do evento}

A definição do evento é de livre escolha do pesquisador, mas deve seguir, quando possível, as proposições de Van de Ven (1992) quanto ao fato de este ainda estar em desenvolvimento. A intuição do pesquisador participa ativamente na avaliação do grau de influência de determinado evento no processo como um todo. Evidentemente, a escolha também estará condicionada ao interesse e disponibilidade dos agentes em participarem da pesquisa e à possibilidade de acesso aos documentos e ao próprio espaço em que o evento acontece.

Após a escolha do evento deve-se fazer um fluxo dos subeventos que o constituem. É esse fluxo que conduzirá a análise das demais etapas.

$2^{\circ}$. Passo: Caracterização dos agentes, dos sistemas organizacionais e do contexto histórico, social e cultural que participam diretamente do evento escolhido Trata-se de um primeiro nível de análise e que procura responder a seguinte questão da tese: “Quem são os agentes que participam diretamente do processo estratégico e quais elementos 
do contexto histórico, social e cultural e dos sistemas organizacionais são mobilizados pela ação destes agentes, identificados a partir da análise dos dados da pesquisa?"

Para caracterizar os agentes o pesquisador buscará responder questões do tipo: 1) quem são eles; qual a sua história de vida; 2) como atuam e que tipos de atividades realizam; 3) com quem interagem; 4) se são criativos, inovadores, orientados para realizações, ou passivos, conservadores e tendentes à conciliação com posições estabelecidas; 5) se demonstram autonomia e independência ou conformidade, adaptação e dependência; 6) quais são as suas principais capacidades e competências.

No nível de grupo, outras informações também são importantes: a composição do grupo, o tempo de permanência/fluidez, o grau de participação dos agentes e os interesses ou motivações que os unem.

A caracterização dos sistemas organizacionais implica em descrever quais as regras e recursos da organização que influenciaram diretamente nas ações do evento em análise, na perspectiva dos entrevistados. Durante o estudo de caso foco da tese, algumas questões salientaram-se, como os aspectos culturais relacionados às profissões, a busca por legitimidade e os jogos políticos existentes no interior da universidade, o que não significa que sejam sempre as mesmas em todos os eventos, pois isto dependerá de cada conjuntura.

Na caracterização, pode-se descrever, de acordo com o evento em análise, por exemplo, os elementos da estrutura formal (no caso das universidades, como se apresentam a estrutura departamental e colegiada, quantos níveis estruturais existem); da estrutura não-formal (se existem comissões e como são formadas ou se existem equipes ou grupos constituídos a partir de projetos e como são formados); da cultura organizacional (quais os elementos/valores que são comuns aos agentes, se existem crenças/valores diferenciadores do grupo em relação aos demais da organização, o que é valorizado na organização); formas de comunicação (freqüência, uso ou não de tecnologias); e tomada de decisão (centralizada/descentralizada, delegação, ausência).

A descrição do contexto deve salientar aspectos históricos, sociais e culturais que formaram a instituição como ela é hoje e que, na interpretação dos agentes, influenciaram determinado 
evento. Espera-se identificar quais os marcos institucionais que constituíram determinada tradição. Podem ser os projetos de reforma, mudanças que resultaram em normas institucionalizadas e internalizadas, que passam de agente para agente em um processo de acumulação, que caracterizam a instituição em estudo. Devem também ser salientados aspectos legitimadores e as crises e oportunidades de momento enfrentadas pela organização. A abrangência dessa descrição está relacionada diretamente ao evento em análise. Um evento mais localizado em uma unidade ou grupo deverá focar o contexto mais relacionado com esse evento. A descrição também é limitada pelo relato dos entrevistados e dos documentos pesquisados.

$3^{\text {o }}$. Passo: Definição e análise integrada dos elementos do núcleo motriz da ação estratégica, a partir da percepção dos agentes

$\mathrm{O}$ que se procura responder nesta fase, corresponde à terceira e à quarta questão da tese: "Como os agentes organizacionais agem e interagem e como surgem e se desenvolvem as ações estratégicas a partir da combinação das três dimensões centrais do esquema?" e; "É possível definir alguns comportamentos dos gestores universitários que colaboram com ou, ao contrário, dificultam a condução do processo?"

Uma questão presente nesta fase do esquema é de que maneira os agentes percebem esse núcleo-motriz onde a ação coletiva ocorre (agência, contexto e sistemas organizacionais) e como eles ajustam suas formas de agir a esse núcleo, ou melhor, como compatibilizam suas capacidades, competências e motivações na busca das estratégias de interesse de um determinado grupo.

Esta fase possui características de um estudo de caso alargado na perspectiva de Burawoy (1998). Aqui se encontram quatro aspectos dessa perspectiva de pesquisa fundamentais para a tese e que o esquema procura retratar: intersubjetividade, processo, estruturação e reconstrução teórica.

Com a intersubjetividade o observador torna-se um participante, experimentando o mundo do outro. Com a lógica do processo, as observações são projetadas no tempo e no espaço, permitindo uma perspectiva de enquadramento. A estruturação permite atender às forças extra-locais e [internas] que moldam os acontecimentos e as situações. Por último, a 
reconstrução teórica, a que Burawoy dá especial ênfase, parte de um quadro teórico existente e procura descobrir anomalias e testar essa teoria (MENDES, 2010, p. 4).

Nessa perspectiva, e em razão do aspecto da reconstrução teórica, mais uma questão da pesquisa também pode ser respondida nesta fase: "Como pode ser interpretado o processo estratégico à luz dos modelos e abordagens utilizados na análise da organização universidade e que conformidades e contradições podem ser detectadas?"

$4^{0}$. Passo: Utilização combinada do esquema com uma teoria (ou modelo) explicativo Para ampliar o número de "lentes analíticas" pode-se combinar a análise fundamentada no esquema analítico com outros modelos teóricos. Nesse caso, pode-se usar como referencial os modelos de Van de Ven (1992) e o modelo de Denis et al (2006), isoladamente, ou conjuntamente, já que eles abordam níveis diferenciados do processo estratégico.

Um quinto passo opcional pode ser acrescentado no qual sejam estabelecidas comparações entre os eventos, detalhadas as principais práxis resultantes e determinado os impactos dos eventos no fenômeno em estudo. Este quinto passo, porém, necessitaria de uma pesquisa longitudinal e não constará da tese.

No capítulo seguinte, dois eventos serão analisados seguindo esses passos. 


\section{APLICAÇÃO DO ESQUEMA ANALÍTICO}

Para a aplicação do esquema analítico elaborado foi escolhido, conforme afirmado anteriormente, o episódio da criação e implantação da Escola de Artes, Ciências e Humanidades (EACH), da Universidade de São Paulo (USP).

A partir das observações iniciais, da realização das primeiras entrevistas e da análise documental sobre a EACH foi possível mapear, definindo uma trajetória, alguns dos eventos significativos desse episódio: a elaboração do projeto para a criação, lançamento da Pedra Fundamental, primeiro processo seletivo para contratação de docentes, aula inaugural, a inauguração do complexo didático, a escolha do primeiro diretor (pró-tempore), a primeira eleição para diretor, inauguração do conjunto didático principal, realização de concurso para 240 vagas para docentes, a primeira mudança no projeto original, mudança no currículo do curso de gestão ambiental, o processo de elaboração do projeto do primeiro curso de mestrado, a elaboração do segundo curso de mestrado, o processo de discussão para mudança no ciclo básico, que são demonstrados cronologicamente por meio do quadro 8 .

\begin{tabular}{|c|l|}
\hline Tempo & \multicolumn{1}{c|}{ Evento } \\
\hline $05 / 2002$ & $\begin{array}{l}\text { Portaria instituindo uma comissão para avaliar a viabilidade para a implantação da } \\
\text { EACH e elaboração do Projeto inicial }\end{array}$ \\
\hline $03 / 2003$ & Lançamento da Pedra Fundamental \\
\hline $11 / 2004$ & Primeiros processos seletivos para a contratação de docentes/ acolhida \\
\hline $02 / 2005$ & Aula inaugural \\
\hline $02 / 2005$ & Inauguração do complexo didático \\
\hline $08 / 2005$ & Escolha do primeiro Diretor (pró-tempore) \\
\hline $01 / 2006$ & Eleição do primeiro Diretor (lista tríplice) \\
\hline $02 / 2006$ & Inauguração do conjunto didático principal \\
\hline 2007 e 2008 & Realização de concursos para 240 vagas para docentes \\
\hline 2008 & Primeira mudança no projeto original \\
\hline 2009 & Mudança no currículo do curso de Gestão Ambiental \\
\hline 2009 & Processo de elaboração do curso de Mestrado em Sistemas Complexos \\
\hline 2009 & Processo de Elaboração do Curso de Mestrado em Sistemas da Informação \\
\hline 2009 & Processo de discussão para mudança no Ciclo Básico \\
\hline
\end{tabular}


Metodologicamente, como especificado no capítulo 3, a pesquisa apoiou-se em método qualitativo de coleta e análise dos dados. Essa análise ocorreu continuamente ao longo da pesquisa, a partir da coleta dos dados iniciais, durante a transcrição das gravações das entrevistas e à medida que novas informações eram obtidas.

Foram realizadas 15 entrevistas em profundidade com gestores e docentes. A escolha dos entrevistados levou em consideração sua participação direta nos eventos ou como testemunhas históricas do processo, sendo que essas informações foram obtidas por meio dos documentos pesquisados e também por indicações feitas pelos primeiros entrevistados.

Durante a realização das entrevistas, embora seguindo um roteiro e procurando abordar com todos os entrevistados os temas centrais definidos na fundamentação teórica, permitindo dessa forma uma certa padronização, situações diversas levaram o entrevistador a deixar de lado algumas questões e aprofundar outras que o fluxo da conversação e os interesses dos entrevistados acabaram por conduzir. Isto trouxe fatos novos que contribuíram para uma melhor compreensão dos eventos.

Para reduzir a quantidade de informações obtidas optou-se por utilizar a técnica de rede de fluxo de eventos, categorizar os dados segundo a proposta do esquema analítico e interrelacioná-los. Ao mesmo tempo, procurou-se explicar o desenvolvimento do processo interpretando o sentido dado pelos agentes sobre suas ações, objetivos e motivos em uma perspectiva de análise crítica.

Uma rede de fluxo de eventos "é útil para expor uma sequência complexa de eventos em termos de ordem cronológica e relações. Ela também pode servir como alicerce para uma análise causal: que eventos levaram a outros eventos e que mecanismos estão subjacentes a essas associações" (COLLIS; HUSSEY, 2005, p. 252). O fluxograma alinha à esquerda da figura os eventos e à direita os fatores influentes de forma positiva (+) e negativa (-), em uma escala de alto, médio e baixo.

$\mathrm{Na}$ análise das entrevistas, utilizaram-se as recomendações metodológicas sugeridas por Mauthener e Dooreta (apud MENDES, 2007, p. 14) que, em uma primeira fase, propõem: 
Um método relacional para análise das entrevistas, centrado nas vozes que dialogam nesses encontros. Recomendam três ou mais leituras das entrevistas completas, cada uma com um objetivo específico. A primeira leitura procura deslindar o enredo (acontecimentos principais; protagonistas e subenredos). [...] Uma terceira leitura deve centrar-se nas relações interpessoais e nas redes sociais mais vastas. Uma quarta leitura procura situar os entrevistados em contextos sociais, culturais e estruturais mais amplos. Este método enfatiza os múltiplos níveis presentes em toda a narrativa. O método relacional na análise das entrevistas procura simultaneamente as semelhanças e diferenças.

Em uma fase seguinte, as entrevistas foram resumidas e procedeu-se a uma análise temática comparativa entre elas a partir dos construtos da pesquisa.

Observe-se que das quinze entrevistas realizadas, dez foram gravadas e cinco foram registradas por meio de observações escritas do pesquisador durante a entrevista em razão dos entrevistados não permitirem a gravação ou o entrevistador perceber que temas polêmicos estavam sendo omitidos em razão da gravação.

Foi feita uma pesquisa documental nas bibliotecas da USP e da EACH e na Secretaria do Conselho Universitário (CO) da USP, bem como em periódicos diários, em que se recuperaram fragmentos de discursos essenciais à investigação e à compreensão dos fatos ocorridos.

Também foram realizadas observações nos espaços da $\mathrm{EACH}$, procurando se familiarizar com sua forma de funcionamento e utilização por parte dos gestores, docentes e alunos. Participouse de eventos, entre os quais, a apresentação dos cursos para vestibulandos e de um Congresso Internacional de Ensino Baseado em Problemas.

O quadro 9 demonstra o perfil dos entrevistados: 
Quadro 9 - Perfil dos Entrevistados

\begin{tabular}{|l|l|c|}
\hline \multicolumn{1}{|c|}{ Função na USP } & \multicolumn{1}{|c|}{ Formação } & $\begin{array}{c}\text { Tempo } \\
\text { aproximado na } \\
\text { USP (em 2010) }\end{array}$ \\
\hline $\begin{array}{l}\text { Professor (Reitor à época da } \\
\text { criação) }\end{array}$ & Graduado em Geologia & 40 anos \\
\hline Professora (Pró-Reitora de & Graduada em Pedagogia & 40 anos \\
\hline $\begin{array}{l}\text { Professora era } \\
\text { Graduação à época da criação) }\end{array}$ & Graduada em Pedagogia & 30 anos \\
\hline $\begin{array}{l}\text { Professor (Vice-Diretor de } \\
\text { Centro à época da criação) }\end{array}$ & Graduado em Economia & 30 anos \\
\hline Coordenador de Curso EACH & Graduado em Administração & 25 anos \\
\hline Coordenador de Curso EACH & Graduado em Comunicação e Artes & 20 anos \\
\hline Coordenador de Curso EACH & Graduado em Turismo & 5 anos \\
\hline Coordenador de Curso EACH & Graduada em Ciências & 20 anos \\
\hline Coordenador de Curso EACH & Graduada em enfermagem & 5 anos \\
\hline Professor da EACH & Graduado em Turismo & 5 anos \\
\hline Professora da EACH & Graduada em Biologia & 5 anos \\
\hline Professor da EACH & Graduado em Ed. Física & 3 anos \\
\hline Professor da EACH & Graduado em Ciências Ambientais & 5 anos \\
\hline Professor da EACH & Graduado em Física & 5 anos \\
\hline Professor da EACH & Graduado em Administração & 4 anos \\
\hline
\end{tabular}

O quadro 10 detalha as entrevistas e principias visitas realizadas:

Quadro 10 - Entrevistas e Visitas Realizadas

\begin{tabular}{|c|c|c|c|}
\hline Data & Duração & Descrição & Procedimento \\
\hline 04-10-2008 & $1 \mathrm{~h}$ & $\begin{array}{llllr}\text { Entrevista } & \text { com professor e um } & \text { dos } \\
\text { membros da comissão central } & \text { de } \\
\text { elaboração do Projeto da EACH } & \end{array}$ & Entrevista \\
\hline 04-10-2008 & $2 \mathrm{~h}$ & $1^{\mathrm{a}}$. Visita à EACH & $\begin{array}{lr}\text { Observar } & \text { o } \\
\text { funcionamento e } & \text { as } \\
\text { instalações } & \\
\end{array}$ \\
\hline $5-10-2008$ & 1h $15 \mathrm{~min}$. & $\begin{array}{l}\text { Entrevista com a Pró-Reitora de } \\
\text { Graduação à época da criação }\end{array}$ & Entrevista \\
\hline $12-10-2008$ & $1 \mathrm{~h}$ & $\begin{array}{l}\text { Entrevista com Coordenador de Curso da } \\
\text { EACH e membro da comissão elaboradora } \\
\text { de Curso }\end{array}$ & Entrevista \\
\hline 03-06-2009 & 1h $15 \mathrm{~min}$. & $\begin{array}{l}\text { Entrevista com Coordenador de Curso da } \\
\text { EACH e membro da comissão elaboradora } \\
\text { de Curso }\end{array}$ & Entrevista \\
\hline 05-06-2009 & $1 \mathrm{~h}$ & $\begin{array}{l}\text { Entrevista com Coordenadora de Curso da } \\
\text { EACH e membro da comissão elaboradora } \\
\text { de Curso }\end{array}$ & Entrevista \\
\hline 05-06-2009 & $50 \mathrm{~min}$. & Encontro com os vestibulandos & Observação e contatos \\
\hline $16-06-2009$ & 1h $15 \mathrm{~min}$. & $\begin{array}{l}\text { Entrevista com Coordenadora de Curso } \\
\text { EACH }\end{array}$ & Entrevista e observação \\
\hline 17-06-2009 & $1 \mathrm{~h}$ & $\begin{array}{l}\text { Entrevista com Coordenador de Curso da } \\
\text { EACH }\end{array}$ & Entrevista \\
\hline 19-06-2009 & $1 \mathrm{~h}$ & $\begin{array}{l}\text { Entrevista com Coordenadora de Curso e } \\
\text { membro da comissão elaboradora de Curso }\end{array}$ & Entrevista \\
\hline 10-09-2009 & $1 \mathrm{~h}$ & $\begin{array}{l}\text { Entrevista com professora e presidente da } \\
\text { comissão de criação e implantação da } \\
\text { EACH }\end{array}$ & Entrevista \\
\hline
\end{tabular}




\begin{tabular}{|c|c|l|l|}
\hline $03-11-2009$ & $1 \mathrm{~h}$ & $\begin{array}{l}\text { Entrevista com professor de Curso da } \\
\text { EACH }\end{array}$ & Entrevista \\
\hline $03-11-2009$ & $1 \mathrm{~h}$ & $\begin{array}{l}\text { Entrevista com professor de Curso da } \\
\text { EACH }\end{array}$ & Entrevista \\
\hline $11 / 13-02-2010$ & $12 \mathrm{~h}$ & $\begin{array}{l}\text { Congresso Internacional de Ensino } \\
\text { Baseado em Problema }\end{array}$ & Observação e contatos \\
\hline $14 / 02 / 2010$ & $50 \mathrm{~min}$. & $\begin{array}{l}\text { Entrevista com professor de Curso da } \\
\text { EACH }\end{array}$ & Entrevista \\
\hline $03-04-2010$ & $1 \mathrm{~h}$ & $\begin{array}{l}\text { Entrevista com professor de Curso da } \\
\text { EACH }\end{array}$ & Entrevista \\
\hline $17-03-2010$ & $1 \mathrm{~h}$ & $\begin{array}{l}\text { Entrevista com professor de Curso da } \\
\text { EACH }\end{array}$ & Entrevista \\
\hline $07-07-2010$ & $1 \mathrm{~h} \mathrm{15min.}$ & Entrevista com professor, ex-Reitor. & Entrevista \\
\hline
\end{tabular}

A partir do mapeamento especificado no quadro 8 foram definidos dois eventos para a operacionalização do esquema: a elaboração do projeto da EACH e a elaboração da proposta do primeiro curso de mestrado, em Sistemas Complexos.

\subsection{Evento 1: A Elaboração do Projeto de Criação EACH}

10. Passo: A partir da escolha do evento "elaboração do projeto de criação da EACH" constrói-se o fluxo de subeventos relacionados: 


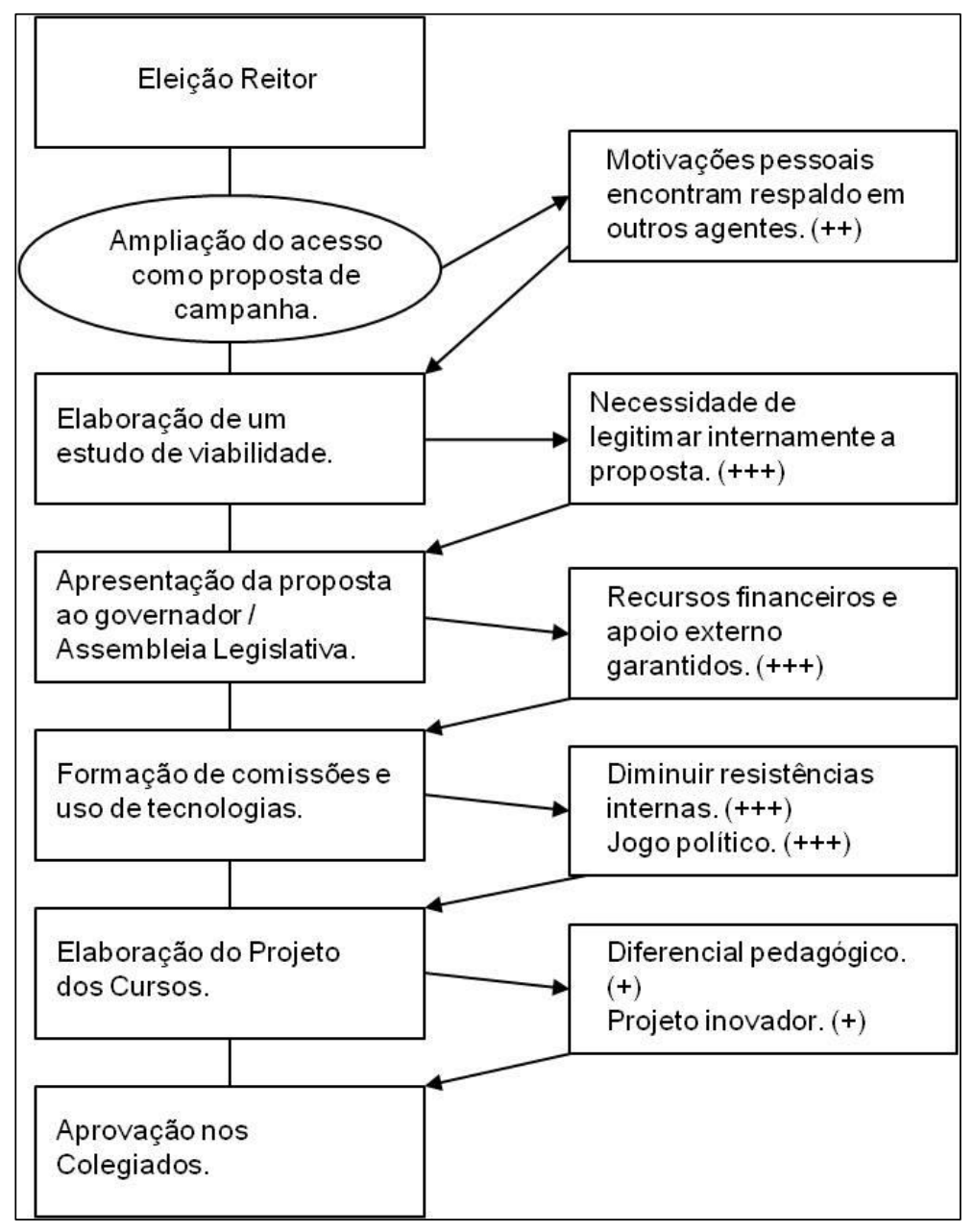

Figura 13 - Fluxograma de Subeventos do evento 1

Começando pela identificação dos principais subeventos que compõe o evento de elaboração do projeto de criação da EACH. Eleição do Prof. Adolpho José Melfi como Reitor da USP para o período 2001/2005. Em sua campanha para a reitoria já apresentava como proposta a necessidade de expandir o número de vagas por meio do melhor aproveitamento dos recursos da universidade. O professor constituiu uma equipe de trabalho que comungava das mesmas idéias em relação à necessidade de expansão de vagas. No início de 2002 é formada a primeira comissão para estudar a viabilidade e elaborar o projeto de uma nova unidade da USP na Zona Leste de São Paulo, sendo esta região escolhida por ser uma reivindicação das comunidades da região, sendo tal fato utilizado como processo legitimador no interior da universidade. A proposta é apresentada ao Governador que se compromete em alocar recursos extra-orçamentários e ao mesmo tempo faz a doação do terreno para instalação da nova unidade. Em seguida, foram formadas várias comissões para elaboração dos projetos arquitetônicos e projetos acadêmicos dos cursos que deveriam ser diferenciados dos da USP 
Oeste, em uma tentativa de diminuir as resistências ao projeto nas várias unidades. Os projetos são aprovados em reuniões na Câmara de Graduação e no Conselho Universitário.

Na sequência, são apresentadas as outras etapas do esquema proposto.

$2^{\mathbf{0}}$. Passo: Descrição do contexto histórico, social e cultural; caracterização dos agentes e dos sistemas organizacionais

O ensino superior constituiu-se, desde os últimos anos do século passado, em importante campo para o desenvolvimento de um contingente cada vez maior de pessoas, além de tornarse de forma mais efetiva um dos pilares da consolidação de um sistema de inovação e desenvolvimento para os países. Esta situação é resultado, no caso brasileiro, de profundas mudanças no mundo do trabalho, da implantação de novas políticas de educação nacional, da modernização da infra-estrutura econômica e da reestruturação produtiva e interiorização do desenvolvimento da economia no País (PORTO; RÉGNIER, 2003).

Tais tendências e processos levaram, no ambiente específico das instituições de educação superior (IES), à seguinte conjuntura: forte expansão e diversificação da demanda de educação superior; diversificação do sistema, valorização da educação como instrumento de mobilidade pessoal; deselitização do ensino superior, o crescimento no número de estudantes economicamente menos favorecidos; presença de alunos de várias faixas etárias; especialização das instituições; multiplicação de novos produtos e serviços associados ao ensino; e acirramento da concorrência.

No campo das políticas educacionais, o Governo Federal passou a adotar, no Governo do Presidente Luís Inácio Lula da Silva (2003-2010), as chamadas ações afirmativas (cotas para alunos de escola pública e minorias étnicas) e a política de ampliação de vagas nas universidades federais pela abertura de novas unidades e de novas vagas nas unidades já existentes, principalmente no turno da noite, voltadas para o "aluno trabalhador".

No Estado de São Paulo, o Partido da Social Democracia Brasileira (PSDB) tem governado por um período considerável (1994-2010). Em seu programa de governo (1988) a educação é vista como prioritária. Suas principais assertivas são: luta pela expansão do ensino público; 
cumprimento do princípio segundo o qual a educação é um direito de todos e dever do Estado; a gratuidade do ensino público em todos os níveis; a gestão democrática do ensino, entre outros. Especificamente sobre a universidade, o programa do partido defende a autonomia da universidade tendo em vista a sua contribuição para o desenvolvimento econômico, tecnológico e cultural do País (PSDB, 1988).

Para melhor compreensão do momento histórico que antecedeu a criação da EACH, a trajetória da USP será dividida em história remota e história recente. Nos dois momentos serão destacados, principalmente, aspectos estruturais, culturais e políticos citados pelos entrevistados e aprofundados em pesquisa documental.

O surgimento da Universidade de São Paulo (USP) no cenário da educação superior brasileira ocorreu em 1934. Algumas reflexões feitas recentemente pelo Professor Honorário da USP, Antônio Cândido de Mello e Souza, testemunha daquele período, servirão para apresentar os fundamentos de sua fundação.

Para o professor Antônio Cândido, a fundação da USP e, em especial, da Faculdade de Filosofia, Ciências e Letras, foi o que se pode denominar de "projeto paulista", caracterizado pela consciência do papel hegemônico que o Estado de São Paulo tinha na federação e da necessidade de formar elites capazes de desempenhá-lo. "Um projeto ilustrado visando a reforçar a elite tradicional para fazer dela um fator de progresso, tradição e renovação" (CÂNDIDO, 2006, p. 300).

O professor Cândido afirma, na continuação de seu relato, que elaborado no intuito de legitimar tradições, o funcionamento do projeto da USP, entretanto, trouxe contradições entre os "sucedâneos aperfeiçoados da elite que as criou" e dos que passaram a atuar como críticos da tradição, ou ainda, de sancionamento da organização da sociedade ou de crítica de sua constituição. É interessante destacar a abordagem de Antônio Cândido sobre a Faculdade de Filosofia:

[...] Na de Filosofia, também independente da origem social, a maioria saía com um espírito crítico que denominei "radicalidade de classe média". Espírito que não era revolucionário, nem configuradamente de esquerda, mas exprimia uma mentalidade democrática inconformada, que em lugar de sancionar a organização da sociedade, a submetia à dúvida radical (Ibid., p. 301). 
O autor, ao completar sua afirmação, esclarece um detalhe importante: o de que esse criticismo da Faculdade, em sua opinião, não era feito por deliberação de programa, "mas simplesmente por ter sido a primeira concentração maciça, no Brasil, de disciplinas cujo estudo favorece a análise crítica da realidade social” (CANDIDO, 2006, p. 301).

O discurso do professor traduz um quadro paradoxal que acompanha a USP ao longo de sua trajetória. Constituída como universidade para uma elite pensante de um país ideal, não pode, para cumprir essa missão, descuidar-se da crítica da realidade na qual está imersa e que, de alguma forma, é pressionada a participar propondo soluções para seus problemas.

Essa questão apresenta vários desdobramentos ao longo da história da universidade, podendose exemplificar hoje em dia na oposição sistemática de idéias e de modos de agir entre grupos de professores na universidade. De um lado, alguns advogam uma universidade centrada na pesquisa (modelo humboltiano), independente de governos e empresas, pautada em um projeto construído por ela mesma. A universidade construindo a ciência básica e como observadora e crítica da sociedade (CHAUÍ, 2001).

Outros tantos acham que a USP deve participar mais ativamente da realidade econômica e social do Estado de São Paulo e do País, ora concentrando seus esforços na formação de profissionais, ora estabelecendo parcerias com as empresas para o desenvolvimento de pesquisa aplicada e com o governo estadual para o desenvolvimento de programas de extensão específicos, como os de formação de professores para o ensino básico, conforme salientado pelo entrevistado 2:

E2: A Universidade é fundamental para o desenvolvimento do País e deve participar das políticas de educação e ciência e tecnologia. A USP tem esse papel também.

Nos debates que antecederam a decisão da criação da EACH estas questões voltaram à superfície, conforme relato de vários dos entrevistados. Assim, em relação aos aspectos estruturais, registraram-se vários questionamentos na universidade sobre onde estaria a pesquisa já que não haveria departamentos na nova unidade? Como a EACH se tratava de uma unidade isolada a quem deveria estar associada? Esse isolamento não ocasionaria uma perda da identidade da unidade em relação aos objetivos e princípios centrais da USP? Seu isolamento não impediria o estabelecimento de "jogos relacionais" dificultando o conflito tão 
presente na universidade? Não seria essa nova unidade uma forma de ingerência de um governo (no caso, para os opositores ao projeto, visto como um partido político) na autonomia da universidade?

Essas duas posições opostas, porém, não encontram respaldo nos princípios de fundação da USP. Conforme salienta o professor Antônio Cândido, para compreender a fundação da Universidade de São Paulo é precisa vê-la à época como uma empresa (no sentido de empreendimento) de renovação cultural pensada segundo uma dialética de tradição e da renovação. Para o autor, "tratava-se de completar e, de certa forma, reformular o ensino superior criando ao lado da tradicional formação profissional centros de investigação e de criação do saber, não apenas da sua aplicação" (CÂNDIDO, 2006, p. 297). Ele reforça a idéia da criação da USP como uma superação do passado pela compreensão do presente, cujo resultado seria o progresso.

Pode-se imaginar a EACH como uma tentativa de renovação da universidade? Seu projeto tendo como pressuposto a interdisciplinaridade, a existência de um ciclo básico, a articulação do ensino, da pesquisa e da extensão não estaria a resgatar um humanismo perdido, não seria uma forma de renovação cultural pensada segundo uma dialética de tradição e renovação, ou seria apenas uma forma de diminuir as pressões sociais sobre a universidade?

Passados mais de setenta e cinco anos desde sua fundação, a USP consolidou-se como um marco não apenas para São Paulo, mas para o Brasil e o mundo, tanto que, na última edição do Shanghai University (2010), que classifica as 500 melhores universidades do mundo, a USP ocupou a $143^{a}$ posição. Seus dados impressionam: possuía em 2010, 88.261 alunos matriculados, sendo 56.998 na graduação e 25.591 na pós-graduação. Oferecia 239 cursos na graduação e 233 programas na pós-graduação. O número de docentes era de 5.732 docentes e 15.341 técnico-administrativos. Era responsável por aproximadamente $28 \%$ da produção científica brasileira e pela formação de $25 \%$ dos doutores em programas de pós-graduação no País. Estava presente na capital do estado de São Paulo e em seis municípios: Bauru, Piracicaba, Pirassununga, Ribeirão Preto, São Carlos e Lorena (ANUÁRIO 2010 - USP).

Um dos eventos mais importantes da história da USP data do ano de 1989, na gestão do Reitor José Goldemberg (1986/1990). Imersa - juntamente com a Universidade de Campinas 
(UNICAMP) e a Universidade Estadual Paulista (UNESP), as outras duas universidades estaduais paulistas - em uma greve docente, os reitores e o Governador à época, Orestes Quércia, iniciaram negociações para viabilizar a autonomia das universidades. Dessas negociações resultou o Decreto n. 29.598, de 2 de fevereiro de 1989, cujo art. $2^{\circ}$. fixa que as liberações mensais de recursos do Tesouro paulista para aquelas universidades devem respeitar o percentual global de $8,4 \%$ da arrecadação de Impostos sobre a Circulação de Mercadorias (ICMS), quota parte do Estado no mês de referência (RANIERI, 1994). Isso representou, de fato, um avanço e um diferencial para as universidades paulistas ao garantir a autonomia acadêmica, administrativa e financeira, com importantes repercussões para o futuro das três universidades, como, por exemplo, no nível das graduações, a total independência em relação às políticas do Governo Federal.

Alguns outros momentos vividos pela instituição nos últimos anos também marcaram sua história e certamente influenciaram sua trajetória futura. Durante a mesma administração do Reitor Goldemberg, ao serem introduzidos novos critérios para a promoção de professores e o progresso na carreira pautados nas publicações em periódicos nacionais e internacionais, a administração universitária promoveu um levantamento da produtividade dos professores. Esse levantamento vazou para a imprensa e resultou na famosa lista de professores improdutivos publicada pelo jornal Folha de São Paulo (1987). Apesar de ter sido um acidente e da matéria conter erros jornalísticos, ela acabou tendo forte impacto interno e externo. Internamente, segundo Goldenberg, "as pessoas se deram conta de que não havia como progredir na carreira sem efetivamente fazer contribuições documentadas" (ROLLEMBERG, 2005a, p. 180). Externamente, significou para a sociedade em geral que uma parte da USP era improdutiva, e que a universidade estava mais preocupada com seus próprios problemas e distanciada da sociedade.

Quase quinze anos depois, a constatação do elitismo exacerbado da universidade, ao serem divulgados dados que demonstravam o baixo percentual de alunos matriculados oriundos das classes sociais mais baixas e da escola pública e da clara ausência de cursos noturnos (Folha de São Paulo, 29/03/2004; 23/01/2004), impedindo dessa forma ao "aluno trabalhador" de freqüentá-la, também receberam muitas críticas dos órgãos de imprensa e da sociedade. 
A própria universidade reconheceu que a maioria dos alunos da escola pública nem sequer conheciam a USP e, portanto, não se candidatavam ao vestibular como relatou o entrevistado 2:

E2: Fizemos uma pesquisa entre os estudantes do ensino médio na Zona Leste e vários não sabiam nem o que era a USP.

Nesse sentido também confluiu um estudo organizado pelo Conselho dos Reitores das Universidades Estaduais Paulistas (CRUESP), sobre a situação do ensino superior no Estado de São Paulo, do qual surgiram orientações no sentido da:

[...] Criação de novos campi e novas unidades em espaços pertencentes às próprias universidades ou ao Estado, além da oferta de maior número de vagas, seja por meio da instituição de novos cursos, seja aumentando-as em cursos já existentes (GOMES, 2005, p. 26).

Política de cotas, expansão de vagas para alunos da escola pública e oferta de cursos no horário noturno representavam pressões bem evidentes, mas que teriam que ser confrontadas com a tradição da USP de alguma forma evidenciada na declaração da Professora Sonia Penin, Pró-Reitora de Graduação no período 2001/2005:

[...] mas não podemos descuidar da função social da universidade, que é a de formar pessoas muito bem preparadas, lideranças das próximas gerações. Não podemos, em hipótese alguma, diminuir as exigências para o ingresso (Folha de São Paulo, 2004)

Assim, na integração da história de fundação da universidade e seus enormes avanços na qualidade de suas atividades ao longo do século XX, mas também nos momentos de crise e pressões sociais é que se configurou o contexto para a criação de mais uma unidade da USP.

A nova unidade, denominada de Campus da USP Leste e que abriga a EACH, localizada na capital, mas em uma região muita afastada do campus central, a Zona Leste, em estágio de urbanização não consolidado, caracterizada por um padrão de renda mais baixo e com altos índices de desemprego, surgiu em torno de muitas expectativas, assim testemunhadas pelo Reitor à época, Prof. Adolpho José Melfi:

A criação de um novo campus da USP na zona leste do município de São Paulo foi visualizada em um contexto que pretendia atingir vários objetivos simultaneamente, como, por exemplo, expandir vagas no ensino superior público, atender melhor e com qualidade comunidades de baixa renda e levar desenvolvimento social, econômico e cultural às áreas carentes e menos favorecidas de nossa sociedade (MELFI, 2005, p. 13). 
Pode-se questionar a razão para a criação de outra unidade da USP na cidade de São Paulo e não em outro município do Estado. A afirmação do Governador do Estado à época da criação, Geraldo Alckmin, procura responder ao questionamento:

Com uma população de mais de quatro milhões de habitantes, maior que a do Uruguai, e uma grande diversidade socioeconômica, a Zona Leste é um "país" dentro da capital paulista (ALCKMIN, 2005, p. 9).

Por parte da reitoria da universidade, a escolha foi também justificada pelo fato de que "desde finais da década de 1970 e começo da de 1980 este era um anseio ao mesmo tempo real e intangível da população local, tendo sido criado inclusive o Movimento de Educação da Zona Leste com este propósito" (ROLLEMBERG, 2005b, p. 19).

Esta justificativa para a escolha do local foi reproduzida pelo entrevistado E2 quando questionado sobre a escolha do local. No entanto, para o entrevistado E1 a escolha teve finalidades políticas:

E1: [...] já que eram 4 milhões de possíveis votos para o Governador nas próximas eleições. A pressão política dos membros da comunidade não era tanta que pudesse influenciar uma decisão da reitoria sobre o local.

Esta última afirmação foi contestada em parte pelo entrevistado E15:

E 15: O Governador entrou nessa depois, quando nós levamos a proposta para ele e as necessidades, como o terreno e os recursos para a construção e para a contratação de professores.

Outro aspecto da questão foi comemorado pelo Governador: o fato de que seis meses após a sua inauguração, a EACH já apresentava índices diferenciados em relação ao avanço na democratização do ensino universitário. Segundo o Governador:

[...] Enquanto a USP - em seu campus da Cidade Universitária - contava com apenas 12\% de afrodescendentes entre seus alunos, o da Zona Leste conta com $21 \%$. No vestibular passado, a antiga USP contava com $28 \%$ de estudantes oriundos de escola pública. Na nova USP Leste, eles já são 47\%. Isso, sem adoção de cotas, ou qualquer outro sistema de pontuação especial para essa faixa da população (ALCKMIN, 2005, p. 9-10).

O Governador aborda uma questão que envolve os níveis de política pública e de política partidária - o PSDB, partido do Governador Alckmin, era contrário à política de cotas do 
Governo Federal - tese reforçada no interior da USP em razão de que os atores contrários à política de cotas eram predominantes no interior dos órgãos colegiados da universidade. Ao mesmo tempo, acompanha a cultura meritocrática presente desde a fundação da USP e o princípio de ser uma universidade formadora da elite intelectual do Brasil.

Este aspecto denota uma das formas de poder, que é o de não tomar uma decisão, ou melhor, nem colocar em pauta. A EACH pode ter servido para, pelo menos naquele momento, não focalizar as questões das cotas como algo prioritário nos processos decisórios da USP.

A conjugação de fatores como a história da USP, o apoio governamental e a pressão social foram importantes, mas não suficientes para desencadear um processo estratégico de criação de uma nova unidade. Sem a participação dos gestores e as características relacionadas à sua formação, interesses e motivações os resultados do processo provavelmente seriam outros.

Os principais agentes no evento de elaboração do projeto da $\mathrm{EACH}$ foram identificados a partir da análise documental e por meio de dados obtidos nas entrevistas. Incluem o Reitor, a a professora Presidente da Comissão Central, os quatro outros membros da Comissão Central, a Pró-Reitora de Graduação e o Chefe de Gabinete da Reitoria. A configuração do contexto e a identificação dos sistemas organizacionais mobilizadores das ações foram definidos a partir da perspectiva desses agentes, obtidos por meio de documentação e de entrevistas em profundidade com quatro deles.

O quadro 11 caracteriza esses oito membros a partir da função que exerciam na universidade, da função no evento de elaboração e dos principais papéis desempenhados.

Quadro 11 - Caracterização dos Agentes - evento 1

\begin{tabular}{|c|l|l|}
\hline Função na universidade & \multicolumn{1}{|c|}{ Função no evento } & \multicolumn{1}{|c|}{ Papel no evento } \\
\hline Reitor & $\begin{array}{l}\text { Presidente do CO e negociador } \\
\text { junto ao Governo do Estado. }\end{array}$ & $\begin{array}{l}\text { Mentor intelectual. Acompanhou } \\
\text { o processo de elaboração e o } \\
\text { início da implementação. }\end{array}$ \\
\hline Professora da FEUSP & Presidente da Comissão Central & $\begin{array}{l}\text { Mentora intelectual do projeto. } \\
\text { Participou ativamente da } \\
\text { elaboração do projeto e até o fim } \\
\text { desta pesquisa continuou } \\
\text { acompanhando a implementação } \\
\text { do projeto. }\end{array}$ \\
\hline Professor da FEA & Membro da Comissão Central & $\begin{array}{l}\text { Participou do processo de } \\
\text { elaboração. }\end{array}$ \\
\hline
\end{tabular}




\begin{tabular}{|c|l|l|}
\hline Professor da FFLCH & Membro da Comissão Central & $\begin{array}{l}\text { Participou do processo de } \\
\text { elaboração. }\end{array}$ \\
\hline Professor da FAU & Membro da Comissão Central & $\begin{array}{l}\text { Participou do processo de } \\
\text { elaboração. }\end{array}$ \\
\hline Professor da FEA & Membro da Comissão Central & $\begin{array}{l}\text { Participou do processo de } \\
\text { elaboração. }\end{array}$ \\
\hline Pró-Reitora de Graduação & $\begin{array}{l}\text { Membro do CO e Presidente da da processo de } \\
\text { Câmara de Graduação }\end{array}$ & $\begin{array}{l}\text { Participou do } \\
\text { elaboração e acompanhou o } \\
\text { início da implementação. }\end{array}$ \\
\hline Chefe de Gabinete da Reitoria & Coordenador geral do projeto & $\begin{array}{l}\text { Representante do Reitor nas } \\
\text { reuniões, elo da Reitoria com as } \\
\text { Comissões. }\end{array}$ \\
\hline
\end{tabular}

Todos os agentes eram professores da universidade há mais de vinte anos e a maioria construiu sua carreira acadêmica (graduação, mestrado e doutorado) na própria USP. Ao mesmo tempo, exerceram anteriormente outras funções na administração da universidade. Por exemplo, o Reitor, antes de ser eleito em 2001, havia sido duas vezes diretor de unidade - do Instituto de Astronomia, Geofísica e Ciências Atmosféricas, o IAG -, Pró-Reitor de pósgraduação na gestão de Flávio Fava de Moraes e Vice-Reitor de Jacques Marcovitch, que o antecedeu.

Aspectos da trajetória histórica dos agentes na USP foram citados nas entrevistas e salientavam os valores sobre os quais as ações destes estavam pautadas durante a criação da EACH:

E 15: "Viemos da Faculdade de Filosofia, Ciências e Letras e essa foi a idéia central da proposta [da $\mathrm{EACH}]$.

A formação e experiência anteriores dos gestores principais fortaleceram a idéia de recriar alguns dos fundamentos do projeto da Faculdade de Filosofia, Ciências e Letras quando dos primórdios da USP e de outras experiências empreendidas em outras unidades da universidade e mesmo externas, principalmente os fundamentos de integração entre as ciências.

E9: Alguns anos atrás, antes de 2001, já existiam algumas unidades que tinham projetos para integração. A faculdade de Filosofia de Ribeirão Preto tinha o primeiro ano propedêutico e eu acho que isso era uma coisa muito boa.

E15: O aluno era moldado, quando você entrava como docente você tinha que se integrar aos projetos já existentes dos departamentos.

E15: Daí o nome, Artes, Ciências e Humanidades, juntar tudo isso eu acho extremamente importante.

E9:Tínhamos conhecimento de outras experiências inovadoras que estavam sendo realizadas em outras universidades. 
Todos eram professores de carreira da USP, faziam parte de uma coalizão dominante já há algum tempo na reitoria da universidade e mantinham boas relações com o Governo Estadual.

A motivação para a ação dos agentes era confluente com a idéia de ampliação do acesso à universidade sem perda da qualidade da instituição, verdadeira "marca" da USP. Denotam a preocupação com a crise de legitimidade apresentada por Santos (1995).

E2: Nós devemos ser uma universidade de pesquisa e de massa, Já temos 80.000 alunos.

E15: A USP e as universidades de uma maneira geral são instituições caras e devem dar retorno à sociedade desse investimento. Uma das formas é ampliar o acesso. No caso da USP, nós deveríamos ampliar as vagas de vestibular de, algo em torno de 6.800 para 10.000 .

E9: O foco era ampliar o acesso para novos estudantes.

Outras motivações também surgiram nas entrevistas. Por exemplo, o fato de um dos membros da Comissão Central ter apresentado projeto semelhante anteriormente, mas que não avançou.

E1: Me interessei em participar, pois anos atrás havia proposto a criação de uma universidade no ABC, mas o projeto foi vetado pelo Mario Covas (ex-Governador do Estado).

A possibilidade de criar um projeto inovador também era um fator de motivação:

E9: Só valeria a pena desde que houvesse a proposta de uma nova experiência, interdisciplinaridade e outras formas de organização.

Havia o interesse dos agentes - não revelado de forma direta nas entrevistas, mas em alguns documentos - em participar da história da USP, que em 2004 comemoraria seus setenta anos:

É importante aqui ressaltar que o Projeto USP Leste contaria desde o início com o envolvimento de número expressivo de docentes, que fariam com que ele viesse a constituir-se no maior programa participativo de toda a história da Universidade de São Paulo, além de marco de referência para o encerramento das atividades comemorativas dos seus setenta anos (GOMES, 2005, p. 27).

A estrutura da USP sofreu modificações após a reforma do estatuto, em 1988. É constituída, do ponto de vista executivo, de quatro níveis: reitoria, unidades, departamentos e cursos. As questões deliberativas centrais são tomadas em um Conselho Universitário e em quatro Conselhos Acadêmicos - de Graduação, de Pós-Graduação, de Pesquisa e de Cultura e Extensão Universitária. Os conselhos são assessorados por comissões permanentes de 
Legislação, de Orçamento e Patrimônio e de Atividades Acadêmicas. Nas unidades há uma Congregação, composta por quatro comissões: de Graduação, de Pós-Graduação, de Pesquisa e de Cultura e Extensão Universitária.

Essa estrutura está relacionada diretamente ao modelo acadêmico fundamentado no trabalho acadêmico autônomo voltado para a indissociabilidade da pesquisa, do ensino e da extensão. Buscava-se a universidade humboltiana com a criação dos departamentos e a integração dos campos de pesquisa e formação de institutos a partir de agrupamento interdisciplinar de pesquisas afins. O princípio que guiou a reforma do estatuto foi o da integração.

Mas, para um grupo expressivo de professores, esta nova USP na realidade esconde outras duas, em estruturas não-formais e informais. Elas representam o modo como a atividade universitária é pensada e exercida, os três tipos podendo existir e coexistir em quaisquer dos institutos e faculdades: a que propicia prestígio curricular ao docente; a que oferece complementação salarial a docentes e pesquisadores; e a universidade pública (CHAUÍ, 2001).

É na confluência da estrutura da universidade e das formas como as atividades devem ser desenvolvidas no interior dos departamentos que a cultura da instituição emerge. Nela estão representadas dicotomias capazes de influenciar todos os processos estratégicos que ocorrem no seu interior e que na realidade traduzem os antagonismos dos grupos ao longo de sua história. Assim, para Chauí (2001), convivem autonomia versus servilismo, representação versus autoritarismo, participação versus centralização e democratização versus modernização. Estão em jogo as finalidades da educação, o papel da docência e o modelo de universidade que se quer realizar.

Para Goldenberg, porém, a USP, sendo a melhor universidade do país, não pode deixar de recuperar a missão de fazer justiça social:

Esses conflitos existem dentro da própria Universidade. A Faculdade de Filosofia foi que me elegeu como reitor e a que mais me antagonizou durante a minha gestão, à medida que eu tentava introduzir critérios de qualidade objetivos. Muitos professores achavam que os critérios não podiam ser objetivos e que, no fundo, eu era um tecnocrata, o que não é verdade (apud ROLLEMBERG, 2005, p. 182). 
Esse antagonismo político e ideológico, traduzido em suas estruturas e cultura (s), confirma o dualismo de valores como democracia e ideologias de grupos, afirmado por Zabalza (2004), o que dificulta, muitas vezes, a criação e implantação de projetos inovadores, alguns dos quais enterrados no nascedouro. Isto implica na construção por parte dos gestores e de grupos de professores de verdadeiros "malabarismos" para tentar ultrapassar esta inércia organizacional. Segundo o próprio Goldenberg:

[...] o que me impressionou com a criação desse novo campus [da $\mathrm{EACH}$ ] é que ele tenha sido criado, porque não é uma coisa trivial. [...] é o máximo da luta contra o conservadorismo que se conseguiu até o momento (apud ROLLEMBERG, 2005, p. 183).

Uma das formas encontradas pelos gestores da USP para elaborar o projeto de uma nova unidade foi a criação de estruturas não-formais (regras não-formais, de acordo com Lima, 2003) denominadas de comissões e grupos de trabalho.

Durante a primeira etapa da elaboração do projeto da EACH - que constituiu o estudo sobre a viabilidade, a elaboração da proposta acadêmica, a definição dos cursos e os detalhes da infraestrutura do novo campus - foram formadas seis comissões: a) Comissão Central; b) Arquitetura Paisagística, Arqueologia; Ciências Ambientais; Turismo; c) Marketing, Promotor Cultural, Serviço Social, Psicologia; d) Políticas Públicas, Cooperativismo, Ciências Atuariais; e) Formação de Professores, Música, Esportes, Moda; f) Comissão de Infraestrutura (GOMES, 2005).

A segunda etapa de elaboração do projeto, desenvolvida após a reunião do Conselho Universitário de 30 de maio de 2003, foram formados os grupos de trabalho que iriam ocuparse da elaboração dos projetos dos cursos a serem oferecidos na USP Leste. Os grupos formados por cerca de sessenta docentes eram os seguintes: a) Informática; b) Ciências Ambientais; c) Administração Pública; d) Lazer e Turismo; e) Formação de Professores; f) Esporte e Saúde; g) Artes; h) Marketing; i) Ciências Básicas.

A terceira etapa, iniciada a partir de outubro de 2003 (Portaria 1506 do Gabinete do Reitor), mobilizou trinta e seis docentes no atendimento de aspectos diversos relacionados com as questões administrativas, ao acompanhamento das obras e à implantação dos cursos. Foram formadas as seguintes comissões: a) Comissão de Infra-estrutura; b) Comissão de Recursos Humanos e Estrutura Organizacional; c) Comissão de Logística e Ambiente de Trabalho; d) 
Comissão de Serviços de Apoio aos Estudantes; e) Comissão de Atividades de Extensão, Cultura e Comunicação; f) Comissão de Instalação, Implementação e Acompanhamento dos Cursos.

Em relação às normas da Universidade, o Estatuto foi citado pelos entrevistados como fator limitador quando da elaboração do projeto da EACH.

O Estatuto da USP vigente passou a vigorar a partir de $1^{\circ}$. de novembro de 1998 , fundamentado na Resolução No. 3461, de 7 de outubro de 1998, assinada pelo Reitor José Goldenberg. Houve várias motivações para a reformulação, porém, na interpretação de Goldenberg havia a necessidade de uma reestruturação organizacional e acadêmica da USP, valorizando a democracia e a qualidade:

\begin{abstract}
Eu resumiria minha passagem pela reitoria da Universidade como sendo caracterizada por dois pontos: [...] a mudança dos estatutos, o que correspondia a uma reestruturação administrativa da universidade. Então foram criadas pró-reitorias que não existiam até então, e foi dado mais poder para os diferentes segmentos da Universidade, com o aumento da participação dos estudantes. Os estatutos, então, se tornaram um pouco mais democráticos [...] (apud ROLLEMBERG, 2005, p. 179).
\end{abstract}

Durante as entrevistas na EACH, alguns entrevistados citaram a impossibilidade de replicar cursos de uma mesma unidade no mesmo município como uma restrição ao projeto da nova unidade o que acabou forçando a elaborar novos cursos. Trata-se do artigo 11, do Título II Da Constituição da Universidade, que determina ser vedada a duplicação de meios para fins idênticos ou equivalentes no mesmo município.

E1: Na realidade, não existia um pré-projeto [para a EACH]. Foi feita uma pesquisa junto às escolas públicas. O que queriam mesmo era medicina. direito, as engenharias [...]. Mas, o estatuto não permitiria uma duplicação de cursos.

Para o entrevistado 15, isso poderia ser contornado, mas uma mudança estatutária demandaria muito tempo.

E15: Podíamos ter proposto uma reforma no Estatuto, mas tudo isso leva muito tempo.

Para o entrevistado 13 tal fato denota a preocupação em implantar a nova unidade ainda no mandato do Governador. 
E13: Na verdade isso foi pressa, porque o projeto precisava sair com o Alckmin no governo, teve uma correria aí para fazer as coisas, depois a gente vai resolvendo.

Outros aspectos da dimensão cultural da Universidade, como a democracia e a valorização do acadêmico, foram destacados pelos entrevistados de diversas maneiras:

E10: Venho de uma experiência de vinte anos no ensino privado. O que me motivou a ingressar na USP foi a possibilidade de vivenciar um ambiente democrático, onde eu possa expressar as minhas opiniões sem problemas. [...] Mas eu também queria ir para uma área acadêmica, área da pesquisa, onde eu tivesse contato com pesquisadores e onde a gente tivesse uma liberdade. Acho que as universidades públicas elas dão condições e liberdade.

E6: Ter a oportunidade de ingressar em uma universidade tradicional como a USP era muito importante. Teríamos a oportunidade de realizar pesquisas, participar de grupos [...].

A partir da descrição da dimensão contextual que envolveu o evento, os agentes e suas histórias de vida e elementos da estrutura e da cultura da USP mais relacionados, pode-se tentar integrá-los na análise.

3. Passo: Definição e análise integrada dos elementos das três dimensões participantes do evento, a partir da percepção dos agentes

Nessa conjuntura apresentada acima, o processo de elaboração do projeto da EACH foi desenvolvido.

Sobre a elaboração do projeto da EACH, o Prof. Celso de Barros Gomes (coordenador geral da EACH à época da implantação) afirma que sua construção foi um processo participativo. Foram constituídas várias comissões para dar conta da elaboração.

A primeira, a partir da publicação da Portaria do Reitor n. 618, de 29 de maio de 2002, “constituía Comissão para avaliar a possibilidade e a conveniência de transformar em realidade a sugestão de criação de uma nova unidade naquela região tão densamente povoada e carente desse serviço especializado" (GOMES, 2005, p. 25).

Essa Comissão Central (com cinco membros), formada para estudo e elaboração dos princípios e diretrizes gerais da nova unidade, após certo período de tempo, apresentou um relatório inicial ao Reitor "o qual indicava a concepção de um projeto inovador que 
preservasse as qualidades indiscutíveis da Universidade de São Paulo, embora modificando alguns elementos passíveis de aperfeiçoamento, tanto do ponto de vista acadêmico como de estrutura e gestão" (KRASILCHIK, 2005, p. 84).

A afirmação ressalta alguns aspectos importantes para a compreensão da formulação e implementação da estratégia da EACH. A nova unidade, apesar de se constituir em um projeto inovador, não romperia com a tradição da Universidade e com as suas qualidades reconhecidas. Não era o caso de se fazer outra universidade, com outras características. Seria a mesma com 'aperfeiçoamentos' acadêmicos, estruturais e na gestão. Ou seja, os resultados esperados com a nova unidade, e de acordo com a cultura uspiana, deveriam ser os mais altos possíveis.

Percebe-se uma confluência dos valores expressos pelos agentes (intersubjetividade) com os valores da própria USP (cultura da organização). Ou seja, o desempenho que se espera é o da própria USP - não é uma USP B. O projeto especifica como o trabalho deveria ser feito.

Para alcançar isso, as principais diretrizes deste primeiro relatório indicavam os seguintes pontos:

- Deveriam ser criados cursos inexistentes em outros campi;

- A nova unidade deveria pautar-se pela inovação e zelar pela qualidade do ensino, da pesquisa, da extensão e de serviços, que confere padrão de excelência à Universidade;

- Deveria atender à expansão do ensino médio e ampliar a diversidade de alunos;

- Deveria ser uma escola em que "convivessem professores e pesquisadores de várias áreas em atmosfera de produção, disseminação e aplicação de conhecimento, sem fronteiras como barreiras" (KRASILCHIK, 2005, p. 85);

- "Os cursos deveriam oferecer aos alunos uma formação rigorosa e visão ampla da sociedade em que atuam como indivíduos, profissionais e cidadãos" (KRASILCHICK, 2005, p. 85).

Aspectos da estrutura organizacional, como as normas estatutárias (pelo Estatuto da USP, de 1988, não é permitido a duplicação de cursos na mesma cidade), da cultura (valor principal da qualidade acadêmica, da formação rigorosa, como o trabalho deve ser feito) e do contexto de 
influência (pressão por expansão de vagas e crescimento da diversidade) aparecem contemplados nessas diretrizes. Mas, há um elemento inovador - um ambiente sem barreiras na produção, disseminação e produção do conhecimento - que funciona como um diferencial da proposta, um elemento que poderia ser utilizado em processos políticos de convencimento sobre a necessidade da criação e implantação da nova unidade. Comprova-se, dessa forma, que conteúdo e processo estratégico, neste caso, caminharam de forma indissociada, agregando-se a eles a questão política.

Ao fim do processo de elaboração da proposta contabilizaram-se vinte formações, entre comissões, subcomissões e grupos de trabalho, "envolvendo cerca de 200 professores" (entrevistado 9) dos diversos departamentos da universidade, alguns participando em mais de uma comissão.

As normas da USP, na qual as diversas unidades possuem autonomia para elaborarem projetos e decidirem pela criação de novos cursos, exigia que os projetos dos cursos fossem elaborados em seus colegiados. A criação de estruturas não-formais (LIMA, 2008) - as comissões e os grupos de trabalho - porém, momentaneamente institucionalizadas pelo Reitor - modelo Adhocrático (MINTZBERG, 2006) - dava a agilidade e legitimidade necessária aos membros das comissões para, a partir de dentro das unidades, mas sem perda do controle por parte da Comissão Central e do Reitor, elaborarem os projetos dos cursos e submeterem aos órgãos colegiados da USP. Pois, segundo o entrevistado 9:

E9: Foi importante não envolver as Congregações, se nós envolvêssemos as congregações isso [o projeto $\mathrm{EACH}]$ nunca teria vingado.

Estrutura de poder, processos decisórios e estilos de liderança, caracterizados por Baldridge et al (1977) e Clegg et al (2004), confluíram com as características do projeto e dos seus agentes.

Os participantes dessas comissões eram quase todos, professores reconhecidos por seus pares, líderes na perspectiva de Hall (2004), o que dava a eles certa autoridade e mobilidade no interior de suas unidades que a Reitoria isoladamente não teria. Dessa forma, foi possível aos gestores administrar um processo estratégico usando a cultura organizacional e neutralizando as fortes subculturas e possíveis oposições ao projeto presentes nas diversas unidades. 
Pode-se analisar também, a partir dos modelos organizacionais de universidade. Os processos foram sempre aprovados previamente pelos colegiados dos cursos e, em seguida, pelo Conselho Universitário. Nesta ação, o modelo colegiado atuou de forma paradoxal, de acordo com Lima (2008). De um lado, possibilitou a discussão e a busca do consenso. Por outro, validou jogos políticos, legitimando as decisões em função de uma hierarquia. Ou seja, é político e burocrático ao mesmo tempo. Pode-se afirmar que existiu uma interpenetração entre os modelos organizacionais sistematizados por Baldridge (1977) e Mintzberg (2006).

A tecnologia foi utilizada nesta fase de obtenção de apoio ao projeto também como um instrumento político focado na comunicação para a comunidade universitária:

[...] Consistiria na medida adotada de disponibilizar, via eletrônica, para a comunidade uspiana, toda a documentação a ser produzida nos vários estudos (GOMES, 2005, p. 27).

E3: O Reitor mandava divulgar tudo sobre a USP Leste no site da USP.

No entanto, para alguns entrevistados esse intento foi alcançado apenas parcialmente. Para o entrevistado E1:

E1: O projeto foi muito mal divulgado internamente. A não ser os membros das comissões, as pessoas na universidade não sabiam o que era essa nova unidade. Aliás, não sabem até hoje.

Apesar das opiniões contraditórias, constatou-se o uso da tecnologia como uma maneira de diminuir as resistências ao projeto, pelo menos ao nível de algumas unidades, e dessa maneira obter apoio fora das comissões.

Outro aspecto a ser salientado, a comissão central do projeto preocupou-se também em interagir com o Poder Legislativo, com as comunidades da Zona Leste, com os alunos das escolas da região, com movimentos sociais, promovendo "enquetes" nas escolas sobre quais cursos os alunos estavam interessados e, quando do projeto finalizado, encontros para discutir o projeto. Neste caso, as ações das lideranças buscavam construir um contexto mais propicio à aceitação do projeto.

E9: Conseguimos apoio e uma participação ativa do Movimento Sem Universidade (MSU) e dos Diretores da maioria das unidades da USP no interior. 
É certo que as resistências ao projeto foram inúmeras. Certamente a idéia dos membros das comunidades, os empresários e os alunos das escolas da Zona Leste era de ter uma USP igual a do campus Butantã, com cursos tradicionais como medicina, direito e engenharia. Os gestores tiveram muito trabalho para convencê-los sobre o novo projeto, sobre os novos processos acadêmicos e os tipos de cursos que seriam ofertados na nova unidade, e esse convencimento ocorreu destacando-se de modo discursivo as inovações do projeto e permitindo uma participação, mesmo que limitada, da comunidade.

E15: É certo que a maioria queria os cursos mais tradicionais de medicina, direito, mas também opinaram por informática e têxtil. Esta é uma área com tradição naquela região.

A preocupação com o Conselho Universitário também deve ser destacada, já que, internamente, as resistências eram presentes em todos os segmentos de professores, alunos e funcionários. Isso é evidente na seguinte afirmativa de Gomes (2005):

\begin{abstract}
A votação da modificação estatutária acabaria por alcançar o quorum mínimo exigido (70), sendo aprovada por 77 votos a favor, 24 abstenções e um contra. Mais uma vez, a exemplo do sucedido por ocasião da aprovação dos cursos da USP Leste, em 18 de maio de 2004, a bancada estudantil se manifestaria maciça e contrariamente aos interesses da nova unidade (GOMES, 2005, p. 52).
\end{abstract}

O Conselho Universitário era permanentemente informado do avanço do projeto e as decisões sobre as questões complexas eram tomadas em plenário. Analisando algumas atas em que o assunto foi tratado identifica-se aqueles atores que sempre foram contrários ao projeto, como a totalidade dos representantes discentes e alguns professores, e os que sempre defendiam a proposta da reitoria. Intui-se ter havido um trabalho político de convencimento da maioria dos membros do $\mathrm{CO}$ e o uso do poder - "quais são as vozes ouvidas na formulação da estratégia?", na perspectiva de Clegg et al (2004).

Os sindicatos na USP possuem o poder de deflagrar greves e manifestações internas, porém para o entrevistado E15, a Associação dos Docentes da USP (ADUSP) não conseguiu mobilizar outros sindicatos e associações existentes na USP:

E 15: A resistência dos sindicatos internos não foi muito grande, pois o projeto tinha um apelo social de inclusão muito importante, exceção da ADUSP, com o discurso de que vão criar uma USP de segunda e vão tirar o dinheiro das outras unidades. 
O sucesso no alcance de apoio ao projeto é demonstrado pela aprovação quase integral das propostas das onze comissões encarregadas de elaborarem os projetos dos novos cursos, segundo depoimento de um entrevistado:

E 15: "Os cursos passaram sem grandes problemas, com exceção de Artes, o que não entendo até hoje porque".

Dessa forma, pode-se concluir que os líderes (agentes) tiveram bastante perícia em utilizar tanto as características da estrutura mecanizada quanto as da burocracia profissional (MINTZBERG, 2006) presentes na USP. Para alcançar esse intento, porém, o conteúdo do projeto inicial da nova unidade foi essencial, pois por meio dele puderam atribuir e difundir significados (relacionados com inovação, aumento da legitimidade institucional, por exemplo) para os demais membros da organização e também para os grupos e organizações do contexto de influência, na linha da estratégia vista como um modelo interpretativo, na abordagem de Chaffee (1985) ou no comportamento estratégico simbólico das lideranças em Hart (2002).

Ultrapassar essas resistências também requereu um enorme exercício de política universitária, na linha da liderança política de Pfeffer e Salancick (1974), apesar da pesquisa não ter detectado essa ação de forma premeditada. É mais provável, pelo perfil dos gestores envolvidos no evento, que sua cognoscitividade (GIDDENS, 2003), ou seja, saber exatamente como agir de acordo com o contexto em que a ação ocorre, tenha prevalecido nesse caso. $\mathrm{Ou}$ seja, os líderes foram capazes de promover a articulação da experiência e dos sentidos compartilhados dos grupos sociais de forma a viabilizar determinados modos de ação de acordo com a intenção estratégica.

O envolvimento do Reitor, da Presidente da Comissão Central e do Chefe de Gabinete mostrou que os gestores estavam imersos no processo, construindo as redes possíveis, destacando os valores esperados e utilizando rotinas e ferramentas da universidade (fóruns de discussão, reuniões de câmaras, encontros, tecnologia etc.) para dinamizar o processo, caracterizando neste aspecto o gestor transacional de Hart (2002), também se utilizando das sete atividades genéricas do modelo Valmra et al (2006), inclusive a de controle e ajuste.

Destaque-se ainda que o papel assumido pela Presidente da Comissão de mentora e divulgadora da proposta permaneceu durante o período da pesquisa. Quando dos primeiros 
professores selecionados, a professora participou ativamente dos encontros de acolhimento e socialização que duravam alguns dias, demonstrando saber usar estrategicamente de práticas organizacionais comuns na universidade. Depois, no entanto, esses encontros foram ficando mais restritos em tempo e participação e o próprio ímpeto estratégico sendo diminuído pelo loosely coupled systems (WEICK, 1976) que caracteriza o funcionamento da universidade.

Esses contextos de ações coletivas caracterizaram o processo estratégico no evento, sendo a proposta da EACH elaborada conforme as discussões eram realizadas, mas sem perder o foco nas diretrizes apresentadas inicialmente:

\footnotetext{
E9: Foi entregue ao Reitor, um documento falando, principalmente, o que devia ser feito. Não era um projeto, era a resposta a pergunta que o Reitor tinha feito. Nós achamos que devia. Sim. Com essas características, dá um sentido social, uma comunicação da unidade com o entorno, próximo da sociedade, quer dizer, não fazer uma unidade que ficasse encastoada, uma torre de marfim. E3: A estratégia do projeto foi sendo construída gradativamente, não estava pronta.
}

Seguindo o esquema proposto na tese pode-se afirmar que a partir de uma intenção estratégica inicial - expansão do acesso, mas mantendo a qualidade uspiana (cultura integradora de Martin) - foram desencadeadas ações pelos gestores envolvendo agentes (líderes não-formais) de diversas unidades da USP (uma bem sucedida forma de gerenciar a cultura de diferenciação de Martin e de promover a disseminação de significado da nova estratégia na universidade). Estas ações foram mediadas ou fortalecidas por regras e recursos organizacionais (entre os quais a cultura da participação, a forma de liderança, o uso do poder, a política de persuasão), constituindo-se em eventos ou ações estratégicas que resultaram em novas práxis. A conjunção desses eventos culminou em um projeto formulado que oferecia as condições para a emergência de novas formas de ação, de regras de conduta e de novos princípios de desempenho na nova unidade.

Pode-se concluir que a interseção das características dos agentes, do contexto histórico, social e cultural e do uso de regras e recursos da organização constituiu uma conjuntura propícia no processo de elaboração do projeto da $\mathrm{EACH}$.

$4^{\circ}$. Passo: Análise Combinada com a Abordagem de Van de Ven e Poole

Para a aplicação em pesquisas do esquema proposto em combinação com a abordagem de Van de Ven e Poole (1995) e Van de Ven (1992; 2003) sugere-se os seguintes passos: 
1) Há necessidade de definir uma cronologia de subeventos relacionados ao evento foco, permitindo, dessa forma, uma visão geral no tempo e no espaço do evento em estudo.

2) Seguindo o esquema proposto na tese é fundamental também especificar os agentes que participam do evento: os que tem poder de definir e executar a estratégia e aqueles que podem interferir no processo. Na abordagem de Van de Ven e Poole (1995) é possível considerar esses grupos diferentes como as entidades. Salienta-se, porém, que no evento em análise a observação do processo estratégico será feita a partir do pontode-vista de um grupo específico de gestores e professores.

3) $\mathrm{O}$ pesquisador em seguida deve determinar quais motores estão operando em um determinado evento, a partir das condições de operações apresentadas.

4) Deve estabelecer também como eles estão relacionados (“casamento de modelos").

Como os itens 1 e 2 acima destacados já foram contemplados nas fases anteriores do esquema analítico, procede-se a análise dos itens 3 e 4 sugeridos pelos autores.

Adota-se para a análise uma abordagem indutiva. Segundo o próprio Van de Ven, as etapas da pesquisa podem incluir "observação de processos de estabilidade e mudança ao longo do tempo em algumas entidades organizativas, classificação de dados em categorias significativas e o desenvolvimento de proposições para explicar as observações" (VAN DE VEN, 2003, p. 207).

Constata-se que a progressão de eventos, inicialmente, não seguiu uma sequência prédeterminada. Os eventos foram surgindo durante o processo de elaboração do projeto e configurando a estratégia. Não tinha havido na universidade um fenômeno semelhante, pelo menos na interpretação dos agentes entrevistados, no qual alguns padrões pudessem ser utilizados.

Decorrido um período de tempo do desenvolvimento do evento, porém, um modo prescritivo (Figura 2) ocorre quando os procedimentos de aprovação do projeto da EACH e dos cursos incluíram a aprovação nos órgãos colegiados da universidade. 
Percebe-se claramente, no modo construtivo, o equilíbrio entre os motores teleológico e dialético. Se por um lado, havia uma clara intenção no projeto da EACH demonstrada pelas diretrizes e objetivos definidos inicialmente, portanto, uma perspectiva teleológica, houve também muitas discussões e modificações, principalmente nos projetos dos cursos, caracterizando um processo dialético.

Quando no modo prescritivo, o predomínio é do motor de ciclo de vida, pois os procedimentos de apresentação, discussão e avaliação por parte dos colegiados segue um ciclo próprio na universidade.

Há naturalmente um embate entre esses motores e eles podem ser utilizados para legitimar as ações estratégicas.

A partir do exposto, pode-se concluir que o processo de elaboração do projeto da EACH teve características dos motores teleológico, dialético e ciclo de vida. Porém, pode-se afirmar que foi predominantemente teleológico. Mesmo tendo sido a proposta inicial (oriunda da comissão central) aprimorada com as discussões ao longo do processo, o teor final do projeto estava de acordo com as diretrizes apresentadas inicialmente pelos gestores. Esse grupo agiu de forma reflexiva tendo em vista construir socialmente um sentido para as ações (sensemaking) que fosse comum a todos na universidade.

Por outro lado, a estrutura colegiada da universidade permitiu que os gestores utilizassem uma estratégia política de legitimação do projeto. O ciclo de vida dos projetos na universidade - a trajetória de um projeto nos diversos colegiados, desde sua formulação inicial até a aprovação final - serviu como uma estratégia política para garantir apoio interno. A questão dialética ocorreu, mas foi habilmente controlada pelos agentes da ação estratégica nos embates com os sindicatos, grupos de professores e alunos do $\mathrm{CO}$ e nas próprias discussões para a elaboração dos cursos.

Claramente, desde o início do desenvolvimento desse evento, há motores de mudança atuando. Dessa forma, não podemos entendê-lo de um ponto de vista de um modelo de “anarquia organizada". A questão teleológica no evento é clara, pois as diretrizes e objetivos são pontuados pelos gestores de tal forma que há um imbricamento com os motores de ciclo de vida e dialético ao longo do evento. 
Percebe-se a impossibilidade, neste evento, de caracterizar o processo estratégico em uma única abordagem na perspectiva de Van de Ven e Poole.

\subsection{Evento 2: Elaboração do Projeto do Curso de Mestrado em Sistemas Complexos}

10. Passo: A partir da escolha do evento "elaboração do projeto do curso de mestrado em sistemas complexos" constrói-se o fluxo de subeventos relacionados:

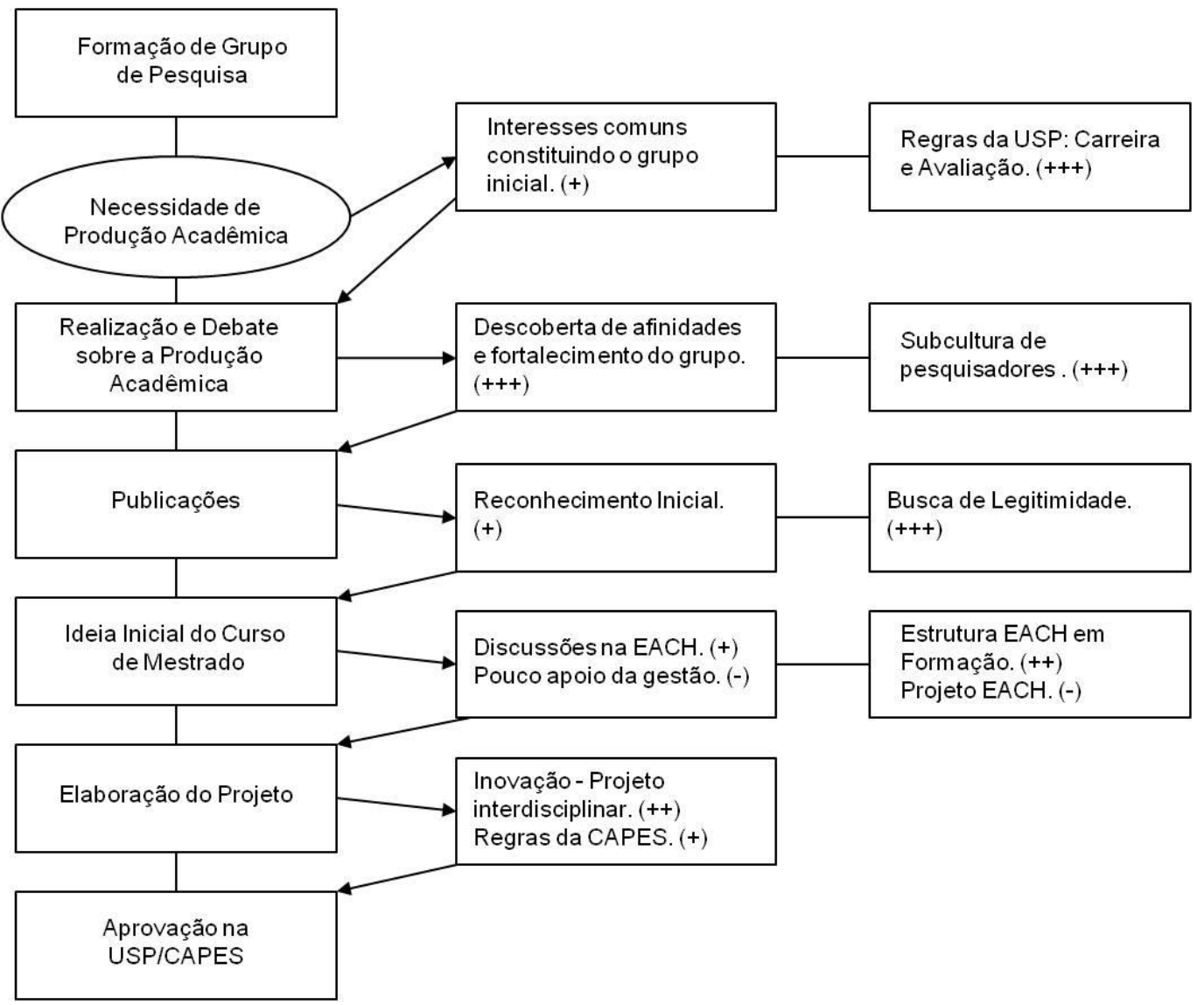

Figura 14 - Fluxograma de Subeventos do Evento 2.

A partir da constituição inicial de um grupo de pesquisa, tendo em vista atender aos interesses individuais e às regras relacionadas com a carreira na USP, um grupo de pesquisadores na área das ciências hard (físicos, biólogos, economistas e engenheiros) começou a realizar uma série de interações. Por meio de publicações e da descoberta de afinidades, o grupo se 
fortaleceu obtendo algum reconhecimento na EACH e na USP. Com o decorrer dos encontros, surge a idéia de elaborar um mestrado em Sistemas Complexos que a princípio não recebeu apoio interno, mas que em função da estrutura e da cultura em formação da nova unidade e da obtenção da aprovação nos colegiados internos e externos pode ser desenvolvido.

Na sequência, são apresentadas as demais etapas do esquema proposto.

$2^{\circ}$. Passo: Descrição do contexto histórico, social e cultural; caracterização dos agentes e dos sistemas organizacionais.

Na caracterização dos agentes participantes do evento três aspectos se salientaram. A maior parte dos professores constituinte do grupo elaborador da proposta era formada por professores jovens, oriundos de doutoramento em institutos de ciência na própria USP e que trouxeram para a nova unidade muito da cultura uspiana de valorização da pesquisa básica. Havia também um grupo pequeno de professores da USP Oeste que ao solicitarem transferência para EACH buscavam novas oportunidades de atuação profissional. Também ficou claro nas entrevistas e no comportamento observado o fato deles serem indivíduos orientados para realizações e seus valores estarem pautados na autonomia, na independência e na integridade pessoal.

Dos doze agentes que compunham o grupo à época da pesquisa, oito participaram do grupo inicial e outros quatro se integraram em seguida. Foram identificados por meio de dados obtidos nas entrevistas e por consulta ao site da EACH. Incluem predominantemente professores que ingressaram na EACH por concurso público nos anos de 2005, 2006 e 2007. Ressalte-se que a configuração do contexto e dos sistemas organizacionais mobilizados pelas ações estratégicas foi definida a partir da perspectiva desses agentes, obtida por meio de entrevistas em profundidade com três membros desse grupo. O Quadro 12 identifica-os e especifica o ano de ingresso e a formação de cada membro. 
Quadro 12 - Caracterização dos Agentes - Evento 2.

\begin{tabular}{|c|c|c|}
\hline Nome & $\begin{array}{l}\text { Ano de ingresso na } \\
\text { EACH }\end{array}$ & Formação \\
\hline $\begin{array}{l}\text { Ana-Amelia } \\
\text { Benedito Silva }\end{array}$ & 2005 & $\begin{array}{l}\text { Engenharia eletrônica, mestrado e doutorado em } \\
\text { Automação e controle - USP }\end{array}$ \\
\hline André Martins & 2005 & Graduado, mestre e doutor em física pela USP. \\
\hline Camilo Neto & 2005 & Graduado, mestre e doutor em física pela USP. \\
\hline Carla Morsello & 2005 & $\begin{array}{l}\text { Graduada em Ciências Biológicas - USP, mestrado e } \\
\text { doutorado em Ciências Ambientais. }\end{array}$ \\
\hline $\begin{array}{l}\text { Carlos de Brito } \\
\text { Pereira }\end{array}$ & 2005 & $\begin{array}{l}\text { Graduado em economia, Mestre e Doutor em } \\
\text { Administração USP }\end{array}$ \\
\hline Cristina Adams & 2005 & $\begin{array}{l}\text { Graduada em Ciências Biológicas - USP, mestrado em } \\
\text { Ciência Ambiental e doutorado em ecologia. }\end{array}$ \\
\hline Fernando Coelho & 2007 & $\begin{array}{l}\text { Graduado em ciências econômicas (USP) e mestrado e } \\
\text { doutorado em administração pública (FGV-SP). }\end{array}$ \\
\hline Fernando Ferreira & 2006 & Graduado, mestre e doutor em física pela USP. \\
\hline Flávia Mori Sarti & 2006 & $\begin{array}{l}\text { Graduada em economia e nutrição, doutora em nutrição } \\
\text { pela USP. }\end{array}$ \\
\hline Francisco Alvarez & $\begin{array}{l}\text { Transferência a } \\
\text { pedido da USP Oeste }\end{array}$ & $\begin{array}{l}\text { Graduação em ciências econômicas e contábeis, mestre e } \\
\text { doutor em administração pela USP. }\end{array}$ \\
\hline Paulo Sinisgali & $\begin{array}{l}\text { Transferência a } \\
\text { pedido da USP Oeste }\end{array}$ & $\begin{array}{l}\text { Graduação em engenharia civil e sanitária, mestrado em } \\
\text { ciência ambiental, doutorado em economia aplicada. }\end{array}$ \\
\hline Renato Vicente & 2006 & $\begin{array}{l}\text { Graduado em ciências moleculares, mestre e doutor em } \\
\text { física. }\end{array}$ \\
\hline
\end{tabular}

A motivação para a formação, inicialmente, de um grupo de pesquisa, era a possibilidade de apresentar e discutir as pesquisas realizadas individualmente pelos professores e não foi algo planejado antecipadamente, segundo o entrevistado 13.

\begin{abstract}
E13: Basicamente todos nós queríamos fazer pesquisa, éramos todos pesquisadores, nós estávamos aqui, então nós queríamos contribuir para ter um grupo de pesquisa, até para ter uma decisão de longo prazo da carreira, para decidir se ficar aqui, muitos de nós colocava como condição que existisse um ambiente de pesquisa vibrante, o que não havia. Então, era nosso trabalho criar. Começamos a discutir com os colegas o que cada um fazia, a gente descobriu por sorte que havia vários pontos de interesse comuns. Sobre esse aspecto que eu acho que a EACH deveria ser mais planejada, porque a coisa aconteceu por sorte, da mesma forma poderia ter dado azar.
\end{abstract}

Essa afirmação retrata a busca por uma espacialidade que exprimisse a pertença a um nós, que se constrói e se manifesta em recortes territoriais. $\mathrm{O}$ espaço de pertença resulta do conjunto dos recortes que especificam a posição de um ator social e a inserção de seu grupo de pertença num lugar. A procura dos professores da $\mathrm{EACH}$ em encontrar um espaço capaz de definir sua 
posição naquela nova unidade, a própria definição de qual lugar ele pertence - antes, automaticamente ocupado pelos departamentos.

A partir dessa interação inicial formou-se uma afinidade muito grande no grupo, sendo criado um significado (intersubjetividade) muito particular sobre como a EACH deveria funcionar, conforme a afirmação do entrevistado 14 .

E14: [...] Esses físicos e economistas formaram um grupo orgânico. Havia muita aderência, [...] conversar com um é a mesma coisa de conversar com o outro. A mesma forma de pensar a Escola.

Quando questionado sobre como havia surgido a idéia do curso de mestrado, o entrevistado 13 deixa isso bem claro:

E 13: Na verdade essa idéia surgiu do grupo de pesquisa, a gente começou a fazer uma série de seminários já em 2006, 2005/2006, interesses comuns, problemas de aplicação de física em sistemas sociais, começamos a conversar, fazer algumas pesquisas, começamos a produzir algumas coisas juntos, e a gente viu que existe uma tendência, estavam começando a surgir em alguns centros da Europa e dos Estados Unidos estudos sobre sistemas complexos, e a gente achou então que podia criar isso aqui e ser um primeiro centro de referência, começando de um grupo pequeno. Somos doze professores e expandindo, criando algo que pode, a gente espera, que tenha resultados importantes.

A questão da legitimidade da nova unidade perante a USP Oeste e órgãos profissionais externos também influenciou no evento. Alguns entrevistados, mesmo dando sentidos diferentes aos problemas detectados salientaram esse aspecto:

E 11: Há uma preocupação muito grande em encontrarmos um espaço de atuação na USP.

E 6: A questão da legitimidade é complexa na $\mathrm{EACH}$, pois envolve relações com o externo e com o interno. O curso de obstetrícia é um exemplo dessa dificuldade, pois há pouco interesse do nosso Conselho Profissional em abrir espaços para essa nova abordagem da saúde da mulher. E internamente, há muito atrito com a área de saúde da própria USP.

Algumas das razões para a questão da legitimidade tornar-se central na implementação da EACH foi ressaltada pelo entrevistado 14:

E14[...] Como toda nova unidade ela nasce com um certo descrédito. Como há uma bolsa de recursos na universidade, as outras unidades não vêem com bons olhos. Então, tem essa questão da busca de recursos em que o pessoal tenta desqualificar a nova unidade. E tem uma segunda questão, que aí não é um pessoal preocupado com recursos, mas é o pessoal mais de vanguarda, que fica discutindo a questão da qualidade de ensino da USP sem se preocupar com as novas unidades. Ainda mais uma unidade como esta que começou com dez cursos de graduação, o projeto previa a contratação de 270, 280 professores em um período de quatro anos, e até quatro 
mil alunos, e em termos de fluxo de até mil alunos por ano. Isso assusta, diferente de uma pequena unidade que surge aqui e acolá. Então, se percebe claramente, um preconceito muito grande.

Para entender um pouco mais essa questão da legitimidade e sua relação com a pós-graduação na USP é necessário um pouco de história.

A reforma universitária de 1969 trouxe no bojo das mudanças propostas a implantação de um sistema nacional de pós-graduação. O sistema que imperava até o início da década de 1960, uma espécie de qualificação após a graduação, replicava o modelo universitário francês e alemão. A partir de meados da década de sessenta, a influência dos Estados Unidos em vários países do mundo, e no Brasil em particular, também teve repercussões nas instituições universitárias brasileiras.

Na USP, a primeira pós-graduação seguindo esse modelo foi na área de engenharia, na Escola Politécnica, com início em 1964. Rapidamente se ampliou para outras unidades da universidade e, em 1974, segundo o ex-Reitor Miguel Reale (1949/1950; 1969/1973), “a pósgraduação já representava, como que uma outra universidade dentro da universidade, elevando-se a cerca de cinco mil o número de alunos inscritos nos cursos de mestrado e doutorado (MOTOYAMA, 2006, p. 202).

Desde então, a USP é reconhecida como a universidade com alguns dos melhores programas de pós-graduação no Brasil, referência na formação de professores universitários e de pesquisadores para vários estados brasileiros.

Destaque-se o fato de que a implantação da pós-graduação no Brasil trouxe mudanças na estrutura organizacional da universidade, conforme afirma o ex-Reitor da USP, Prof. Roberto Lobo (COELHO, 1992, p. 1).

Ao instituirmos a pós-graduação foi dado um passo de fundamental importância com a criação concomitante de institutos voltados para a pesquisa básica, que, anteriormente, era desenvolvida dentro das faculdades dedicadas à formação de profissionais (médicos, dentistas, farmacêuticos, veterinários, engenheiros, agrônomos, etc.).

Esse fato, segundo o próprio Reitor, teve impacto sobre a graduação: 


\begin{abstract}
A mudança gerou problemas na graduação. Ou seja, a submissão da pesquisa básica à área profissional evoluiu para o quadro oposto, para a total independência da área básica face àquelas que preparam profissionais. Isso não foi bom. Antes da reforma, um professor de Física numa escola de Engenharia ministrava seu curso considerando que seus alunos destinavam-se à Engenharia. O fato de esse professor estar numa escola de Engenharia o forçava a um diálogo permanente com os outros docentes dedicados à formação de engenheiros. Mas quando foi criado o Instituto de Física essa relação se diluiu. E tal fato ocorreu também com os outros institutos Química e Matemática (COELHO, 1992, p. 2).
\end{abstract}

Outro aspecto relevante para o evento em análise refere-se ao fato de que, ao contrário da graduação, na área da pós-graduação a USP segue as políticas traçadas em nível central pelo Ministério da Educação, incluindo as normas específicas de avaliação dos programas de pósgraduação elaboradas pelos comitês de área da CAPES.

Como se sabe, o acesso a bolsas de pesquisa e outros recursos depende, em parte, da avaliação dos programas de pós-graduação, feita a cada três anos pela Capes. Para continuar em atividade, os programas precisam obter no mínimo nota 3 , em escala que vai até 7 . É para avaliá-los que a Capes estabelece comitês das diferentes áreas de conhecimento; os elementos de avaliação variam de peso em cada uma delas. Estrutura curricular, atividades de pesquisa, formação, integração com a graduação e infraestrutura estão entre os fatores considerados para análise. O principal deles, contudo, é o número de artigos que os docentes vinculados ao programa conseguem publicar em revistas científicas de prestígio (BARBOUR; CRISPINIANO, 2009, p. 46).

Muitos desses critérios têm gerado críticas por parte de professores e associações de professores em razão de uniformizar critérios avaliativos em um sistema muito diferenciado como o brasileiro. Ao mesmo tempo, acabam por introduzir nas próprias universidades esses critérios "produtivistas" para a ascensão interna na carreira docente.

\footnotetext{
Os critérios adotados pela Coordenação de Aperfeiçoamento de Pessoal de Nível Superior, a conhecida Capes, para avaliação dos cursos de pós-graduação, imprimiram à universidade pública uma lógica produtivista, na qual a qualidade vem sendo preterida em favor da quantidade. $\mathrm{Na}$ USP, nos últimos anos, exacerbaram-se as exigências de aceleração e de intensificação da produção docente. Os professores vêem-se às voltas com pedidos de relatórios e com pressões dos colegiados e órgãos encarregados, no âmbito da Reitoria e das unidades, de fiscalizar o estrito cumprimento das normas da Capes (BARNOUR; CRISPINIANO, 2009, p. 45).
}

Na USP, certamente influenciada por essas regras, a Comissão Especial de Regime de Trabalho (CERT) regulamentou 73 indicadores de avaliação docente, sendo que pelo menos 42 desses indicadores referem-se à pesquisa e à pós-graduação.

Torna-se mais fácil compreender, a partir desse contexto histórico, social e cultural no qual os professores da EACH estiveram imersos - formados em institutos de pesquisa básica e submetidos a critérios de avaliação com base na pós-graduação brasileira - o dilema em que 
estes se viram ao ingressarem em uma Escola predominantemente de graduação, na própria USP.

A Escola de Artes, Ciências e Humanidades (EACH), possuía, quatro anos após a sua criação, em 2009, cerca de 4200 alunos, 210 professores e 130 funcionários. Em seu interior eram desenvolvidos 10 cursos de graduação e procurava-se realizar ensino, pesquisa e extensão de forma integrada.

Sua estrutura organizacional é constituída basicamente em dois níveis: direção e coordenações de cursos, sendo o diretor e os coordenadores escolhidos por meio de eleição. Destaque-se que, ao contrário das demais unidades das USP, a EACH foi criada sem departamentos.

Como meio de buscar uma maior interação entre os docentes, construir novas formas de organização das relações entre os membros da comunidade e privilegiar perspectivas de trabalho mais colaborativas e multidisciplinares (GOMES, 2005, p. 52).

Trata-se de uma tentativa de aliar, no projeto da nova unidade, a estrutura organizacional aos seus pressupostos acadêmicos de interdisciplinaridade e de maior integração acadêmica entre os cursos.

Segundo seu primeiro Regimento (Resolução 5234, de 29 de agosto de 2005), a administração geral da EACH seria constituída pelos seguintes órgãos: a) Congregação; b) Conselho Técnico Administrativo; c) Diretoria; d) Comissão de Graduação; e) Comissão de Pesquisa e Pós-Graduação; f) Comissão de Cultura e Extensão Universitária.

Ressalte-se ser responsabilidade da Congregação o planejamento e a evolução das atividades acadêmicas da EACH, sendo a sua composição a seguinte: a) Diretor como Presidente; b) Vice-Diretor; c) Presidentes das Comissões; d) todos os professores titulares da EACH; e) representantes das outras categorias docentes; f) representantes dos alunos.

Nos primeiros anos de funcionamento da EACH, as principais discussões acadêmicas deveriam ocorrer nas comissões. Como exemplo, o inciso II do Artigo $18^{\circ}$. do Regimento da EACH estabelece: 
II - à Comissão de Pesquisa e Pós-Graduação cabe propor à Congregação a criação de programas de pós-graduação, zelar pela sua execução, coordenar as atividades didático-científicas pertinentes, bem como traçar diretrizes de política científica e cultural, assegurando o desenvolvimento de programas institucionais de investigação científica (REGIMENTO GERAL - EACH, 2005).

Constatou-se que nesses primeiros anos de funcionamento, a nova unidade apresentou uma estrutura ainda em consolidação, com características de ser flexível e tolerante aos processos informais, propiciando uma ampla gama de variações no seu funcionamento.

Por seu um elemento estruturante, na sequência são abordados mais alguns aspectos do projeto estratégico da EACH.

A partir das diretrizes citadas anteriormente na tese e que nortearam de uma forma geral a elaboração do projeto da nova unidade, propunha-se que:

O primeiro ano básico deveria incluir, além das disciplinas introdutórias de cada curso, disciplinas gerais que propiciassem visão aberta e cosmopolita dos grandes temas contemporâneos, e atividades de trabalho coletivo para o desenvolvimento de uma postura permanente de investigação (KRASILCHIK, 2005, p. 85).

As diretrizes implicam claros indicadores acadêmicos, estruturais e de gestão. Academicamente, a pesquisa é o centro das atividades. Orienta e organiza o ensino, a extensão e os serviços da nova unidade. Porém, busca-se uma pesquisa integrada, na qual a fronteira entre as ciências esteja mais permeável a trabalhos conjuntos entre as áreas. Esperase que a convivência e o diálogo entre gestores, professores, alunos e comunidades constituam-se nos fundamentos do comportamento das pessoas. $\mathrm{O}$ aperfeiçoamento da estrutura e da gestão busca fomentar esse processo.

Convivência e diálogo implicam em espaços estruturados para esse propósito e que com o tempo institucionalizem-se como práticas indispensáveis ao funcionamento da nova unidade. Isso exige, entre outras questões, presença de gestores, professores e alunos na nova unidade, calendário permanente de reuniões e debates sobre questões importantes, formas inovadoras de integrar pesquisadores de áreas diferentes, articulação com segmentos das comunidades vizinhas e participação destas nos processos acadêmicos e organizacionais.

O modelo epistemológico adotado no projeto tem como pressuposto que a ação e o protagonismo dos seres humanos na construção, produção e transformação da realidade 
"passam a serem vistos como uma forma mais adequada para compreender o papel que os estudantes e os professores devem desempenhar na relação entre ensino e aprendizagem" (ARANTES, 2005, p. 103).

Os currículos dos cursos de graduação estão estruturados em três dimensões: o problema, os conteúdos e o grupo. Essas dimensões são trabalhadas por meio da abordagem de Resolução de Problemas articulada com a Aprendizagem Baseada em Projetos, que constituem a essência do ciclo básico da nova unidade.

A abordagem epistemológica e a estrutura curricular reforçam o protagonismo dos alunos e professores em uma perspectiva coletivista, focada na pesquisa integrada e interdisciplinar, necessitando para tanto romper com muito do tradicionalismo presente na universidade, entre os quais a formação de "guetos" (ZABALZA, 2004).

Para Araújo esse rompimento depende da "articulação entre o projeto (estratégia) e as ações de planejamento e gestão operacional que garantam as condições físicas e humanas necessárias à consecução das metas almejadas" (ARAUJO, 2005, p. 135).

O autor destaca a articulação que houve entre a equipe de gestores e funcionários, criada antes do início do funcionamento da nova unidade, e a demanda dos projetos novos oriundos dos cursos criados, resultando em duas frentes de atuação: articulação entre a ocupação física e o projeto acadêmico e a organização da ocupação dos espaços. Também é destacada a experiência de "incubação" do funcionamento administrativo da nova unidade antes de sua inauguração, em ambiente externo à unidade, funcionando como um laboratório de aprendizagem em serviço.

No aspecto tecnologia foi adotada, como ferramenta de apoio ao ensino, o CoL (Cursos onLine), um sistema gerenciador de material didático que permite aos professores gerenciar seus cursos de maneira simples e integrada, por meio da web. "Sua utilização teve como objetivo criar um ambiente acadêmico inovador e rico e trouxe possibilidades de intercâmbio entre docentes e discentes" (ARAUJO, 2005, p. 145). 
$\mathrm{O}$ arquitetônico inicial da nova unidade seguiu, segundo os documentos pesquisados, as demandas dos cursos, mas sempre de acordo com os princípios acadêmicos e organizacionais da nova unidade. Neste aspecto, não foram construídos laboratórios exclusivos para um determinado curso ou para um pesquisador individualmente. O projeto físico deveria seguir o projeto acadêmico.

Observando-se o espaço físico da EACH, ainda em construção quando da realização da pesquisa, nota-se uma praça central localizada entre a biblioteca, um conjunto de auditórios e o prédio conhecido como "Titanic", na realidade um prédio de quatro andares onde ficam as salas de aula e as salas individuais da maioria dos professores em dedicação exclusiva. A idéia de integração foi a motivação passada aos arquitetos e engenheiros pelos idealizadores do projeto, porém, durante as visitas realizadas pelo pesquisador notou-se que ainda ocorre pouca integração entre as pessoas, seja externamente ou internamente.

$3^{\circ}$. Passo: Definição e análise integrada dos elementos das três dimensões participantes do evento, a partir da percepção dos agentes

Nessa conjuntura apresentada acima, o processo de elaboração do projeto do curso de mestrado em Sistemas Complexos foi desenvolvido.

Pode-se delimitar como marco inicial do evento a constituição de um grupo de pesquisa cujo objetivo central era a necessidade de todo professor em uma universidade como a USP produzir conhecimento. Além disso, as regras da carreira docente e os sistemas de avaliação na USP pressupõem um professor engajado em projetos de pesquisa e de pós-graduação.

O fato da maioria dos professores desse grupo emergente ser constituído por ex-alunos da USP, formados em institutos de pesquisa básica nos quais mais do que o ensino a pesquisa é o centro, permitiu que logo fossem construídas afinidades entre eles, gerando um fortalecimento automático do grupo.

Toda a interpretação do contexto de atuação na EACH desses professores foi então condicionada por um entrelaçamento entre a cultura da USP, a subcultura deles como pesquisadores e dos valores e crenças relativos à forma de atuação de um professor em uma universidade de ponta no ambiente universitário brasileiro. 
Contexto institucional, cultura USP e subcultura dos professores se reforçaram mutuamente criando parte de uma conjuntura propícia ao surgimento de um projeto que em tese não possuía muita relação com os princípios da estratégia original da EACH.

Ao mesmo tempo, outras questões também contribuíram para que o evento ocorresse, conforme é possível interpretar a partir do depoimento do entrevistado 13, quando questionado sobre se a nova estrutura havia contribuído para a assunção do projeto do mestrado:

E 13: Olha, eu não sei. A estrutura nova foi benéfica por motivos errados. Porque, boa parte das nossas lideranças aqui, não eram lideranças. Não existiam lideranças acadêmicas. Boa parte das pessoas que vieram para cá não eram lideranças acadêmicas no sentido da USP, ou seja, não tinham pesquisa e pesquisa internacional. $\mathrm{O}$ que quer dizer, que quando contrataram um monte de doutores que tinham tanta liderança quanto os chefes, como não havia uma estrutura tão formal nós estávamos livres, e a gente pode fazer o que quis. No caso da pós isso ocorreu. Não houve um único cacique, nós reunimos um monte de autores que tinham interesses em uma área comum, que não teria surgido no Butantã, porque isso teria entrado nas estruturas formais de cada especialidade, cada um de nós estaria em uma escola diferente, e o fato de a gente ter toda essa liberdade aqui permitiu que a gente inovasse. Não teria surgido lá. Então teve vantagens. Por outro lado, por não ter uma liderança clara, significa que por anos as pessoas que faziam pesquisa realizavam no Butantã, não havia pesquisa na escola. Havia pesquisa dos professores da escola, não da escola. Durou mais tempo porque não havia alguém que dissesse, olha este é o projeto de pesquisa, as pessoas estão sendo contratadas para trabalhar com isso, quando a escola foi planejada só pensaram na graduação. O que para o padrão USP é muito fraco.

A estrutura mais horizontal da $\mathrm{EACH}$, sem departamentos, permitiu que docentes de áreas diferentes tivessem uma maior mobilidade interna, oportunizando a formação de grupos. Ao mesmo tempo, o não reconhecimento das lideranças da EACH como autoridades acadêmicas e a ausência de um direcionamento claro e permanente na implementação do projeto da EACH culminaram em uma percepção da situação por parte dos agentes na qual priorizaram seus próprios interesses, salientados por seus valores e crenças.

O fator liderança que sobressai na afirmativa acima merece um maior detalhamento. Quando das várias entrevistas realizadas percebeu-se que o papel do diretor da $\mathrm{EACH}$ era entendido como o de um administrador de rotinas, um prefeito do campus, ou o representante da estrutura hierárquica. Ele não era reconhecido como uma autoridade acadêmica pelos seus pares. A defesa dos principais pressupostos do projeto da EACH era feita por outros professores quase sempre ligados ao Ciclo Básico e à Metodologia Baseada em Problemas. A 
interferência do diretor da EACH em assuntos acadêmicos não era muito clara, como também não eram outros trâmites, conforme as afirmações abaixo:

\begin{abstract}
E14: [...] Aqui eu acho que é uma coisa complicada. Porque veja, ao mesmo tempo o diretor é cobrado como se fosse um prefeito de campus. Queira ou não acaba sobrando isso para ele. E às vezes, o controle sobre as atividades de pesquisa e extensão seria dele. Porque o controle do coordenador de curso é só sobre as atividades de ensino. Inclusive a gente só recorre ao coordenador de curso em momentos de carga horária, em questões relativas aos afastamentos nossos quando vai ter impacto em termos de carga horária. Meu projeto de pesquisa não passa pelo coordenador, vai direto para a diretoria que vai encaminhar para as instâncias superiores.

E4: Os trâmites ainda não estão muito claros. Com a saída dos departamentos não se sabe se isso é tarefa dos coordenadores ou não.
\end{abstract}

Dessa forma, as características do contexto de ação do grupo reforçaram, em parte, uma forma de poder típica do modelo de burocracia profissional (MINTZBERG, 2006). A estratégia como um padrão, algo em torno do qual existe consenso, não possuía significado nesse contexto. Na realidade, a ação estratégica da elaboração do curso de mestrado surgiu do efeito cumulativo de ações e decisões que um determinado grupo conseguiu condições para convencer sobre sua implementação em função do poder advindo do conhecimento específico.

Os pesquisadores também estavam cientes desse poder que a especialidade lhes conferia:

E 13: Os primeiros gestores estavam afastados da pesquisa, não entendiam nada disso. Não tinham muito como enfrentar a gente.

Mas, em determinado momento, o poder oriundo da burocracia profissional foi confrontado por outros poderes existentes na EACH. Segundo o entrevistado 14:

E 14: Enquanto o projeto [do curso de sistemas complexos] estava sendo escrito se fazia uma discussão na escola, assim. Bom, essa é uma escola interdisciplinar, vai se aceitar programas no interior da escola que não sejam interdisciplinares?

[...] Debates ocorriam nas instâncias informais da escola, mas chegavam na congregação. E isso gerou uma série de embates não só de idéias, mas inclusive de confrontos pessoais muito fortes.

[...] Era para ser uma escola com poucos programas, mas era muito difícil manter essa posição, pois existem grupos epistêmicos muito diferentes, e ao mesmo tempo dar organicidade a isso.

[...] E teve que batalhar politicamente dentro da escola, pois tinha fortes resistências. Eu posso interpretar assim: consequências políticas - novo programa, novos assentos na congregação.

De algum modo esse embate político ocorreu no interior da Escola, mas teve um vencedor, o grupo de pesquisa. 
Um dos fatores que concorreu para isso pode ter sido a união do grupo, sendo o seu modo de funcionamento um dos fatores de agregação, conforme se pode perceber nas declarações dos entrevistados sobre o funcionamento do grupo, o processo de tomada de decisão sobre a idéia do mestrado e se este tinha alguma vinculação com alguma diretriz da direção da EACH.

\footnotetext{
E10: Nosso grupo desde o começo foi quem estava interessado, [...] bem informal, surgiu tudo informalmente depois nós colocamos dentro do esquema que precisa ser.

E14: Não, a gente foi construindo aos poucos. Em pesquisa e pós-graduação não havia idéia nenhuma. Isso não havia na EACH. Ninguém havia pensado, ninguém que tivesse uma liderança acadêmica que pudesse gestar ali. Não havia lideranças.
}

Outro fator pode ser uma característica da EACH desenvolvida em razão da ausência dos departamentos. Criaram-se outros tipos de relacionamentos, nos quais regras não-formais e informais (LIMA, 2008) foram sendo desenvolvidas na interação, ou seja, a estrutura foi utilizada para gerar ação (GIDDENS, 2003). Procurava-se evitar o fortalecimento da hierarquia formal, fato este que aparece muito evidente como uma cultura comunicativa sendo solidificada na nova unidade, para o bem e para o mal, conforme a entrevistada 10:

E10: Aqui todo mundo sabe de tudo. Há muita fofoca circulando nos emails de professores e alunos, é impossível não tomar conhecimento do que está ocorrendo quase de forma imediata.

Pode-se também concluir que a inexistência dos departamentos permitiu um afrouxamento do sensemaking convencional (WEICK, 1995) e a emergência de um novo círculo de poder. Ao mesmo tempo, criou uma expectativa por alcançar e controlar recursos que os agentes de um determinado grupo presumiam encontrar no ambiente institucional. Nesse aspecto, a ação reflexiva dos agentes (GIDDENS, 2003) possibilitou o desenvolvimento de uma estrutura (organizacional) favorável ao alcance dos objetivos pretendidos.

Por outro lado, a estrutura colegiada internamente serviu muito mais como uma etapa burocrática. Segundo os entrevistados 13 e 14, pouco foi acrescentado ao projeto do mestrado na avaliação da Comissão de Pesquisa e Pós-Graduação da EACH e apenas algumas questões mais formais na Comissão da Pró-Reitoria de Pós-Graduação da USP. O mais importante, para esses entrevistados foi a aprovação na CAPES, pois isso legitimaria o projeto interna e externamente, daí eles durante uma parte da elaboração do projeto guiarem-se pelo modelo da CAPES. A estrutura (regra) reforçando a ação (GIDDENS, 2003). 
E13: O projeto foi encaminhado primeiro aqui dentro, seria para a comissão de pós, mas não havia pós, então era só pesquisa, quer dizer, ainda está assim, deveria ter sido desmembrada, o Regimento da USP diz que são duas, mas aqui ainda não separou... De qualquer forma, você manda para a comissão, é feito um parecer, o parecer interno foi só técnico, não houve nada de mérito, [...] aí, tendo aprovado aqui vai para a pró-reitoria, a pró-reitoria faz mais uma série de análises técnicas, manda pro departamento de pós para ver se está tudo de acordo com os regimentos, passado isso vai para a CAPES. E aí tem que passar todo o processo pela CAPES. A Capes faz outra avaliação. [...] Não, o nosso não houve problemas.

E14: Sim, durante uma etapa da elaboração nos guiamos pela CAPES. Você tem que ter um modelo, [...] como ninguém havia feito um projeto na Escola a gente foi meio que apanhando para descobrir o como se faz, qual o formato que você põe, que informações precisa [...].

Quando questionado sobre se havia alguma relação do projeto de mestrado com alguma orientação estratégica da direção da unidade o entrevistado 13 foi enfático:

E13: Não, foi um processo independente, se alguma coisa aconteceu foi que ela [a administração], atrapalhou bastante. Da estrutura da $\mathrm{EACH}$, quando a gente criou, a gente não sentiu nenhum apoio, criamos por conta própria e tocamos em frente. Tinha gente que não tinha conhecimento do que nós estávamos fazendo e propunham que nós nos uníssemos a outro mestrado. Havia muito ruído no processo na verdade. Mas a gente resolveu, sabíamos o que estávamos fazendo e deu certo.

Intui-se pela declaração que o grupo entendia o projeto da EACH como o projeto de um grupo hierárquico. Não reconhecia como seu ou, pelo menos, como algo central em seus processos de decisão.

O uso dos espaços físicos, as regras de conduta, o uso do tempo e da tecnologia também caracterizaram a forma como o grupo agia e contribuíram para a ação dos agentes.

E13: Não [nas reuniões não tinha uma pauta], eram reuniões de pesquisa mesmo. Alguém apresentava ou um trabalho que estava fazendo, ou um artigo que tinha lido ou alguma coisa que estava interessado em trabalhar. E apesar de ter um apresentador oficial ele só falava a metade do tempo porque as pessoas ficavam falando o tempo inteiro e discutindo aquele assunto. Era uma reunião de pesquisa normal. [...] Tinha um horário oficial, toda a semana, às vezes uma ou outra semana pulava, começou aqui na EACH. Não tinha muito uma coordenação oficial, se você olhar os membros iniciais do grupo eram os físicos que estavam aqui desde o começo, algumas pessoas da economia, e a gente foi aos poucos, e as pessoas foram aos poucos se agregando ao grupo, fomos trazendo pessoas que tinham interesses comuns com a gente,

E10: Usava tudo. Nós trocávamos muitas coisas pelo email, mas essas reuniões eram "face a face".

No aspecto cultural a ação dos agentes denota as três abordagens de Martin e Frost: uma cultura integradora - da USP; uma diferenciada - de pesquisadores; e a de fragmentação, pois o grupo era muito isolado na unidade. Há uma questão paradoxal envolvendo essa dimensão: ao mesmo tempo em que os agentes valorizavam enormemente o ingresso na Universidade de São Paulo, demonstrando orgulho, respeito e enraizamento por sua tradição, se propunham 
também a empreender um projeto inovador, único no ambiente universitário brasileiro, em uma Escola cujo projeto fundado na integração não lhe era compatível.

Prevaleceu, porém, a força da idéia de grupo de referência, que se mostrou fundamental nas ações dos agentes. Após a aprovação em processo seletivo na $\mathrm{EACH}$, muitos professores continuaram realizando suas pesquisas nos laboratórios da USP Oeste, onde poderiam continuar estabelecendo contato com seu(s) grupo (s) de referência e, dessa forma, manteremse atualizados em suas áreas e ganhando apoio interno para seus projetos. Por outro lado, esse distanciamento da EACH impediu a formação de outros laços informais entre os agentes no interior da nova unidade, dificultando a comunicação interna. Subentende-se que a cultura USP e a subcultura de pesquisadores prevaleceu sobre uma cultura ainda em formação na nova unidade.

Reforça-se nesse comportamento uma racionalidade direcionada aos aspectos considerados pelo grupo como mais importantes. Em nenhum momento nas entrevistas, mesmo quando questionados, os agentes demonstraram um maior conhecimento e interesse em integrar a proposta do mestrado ao projeto da EACH. Não reconheciam as lideranças e não consideravam a estratégia como algo que estivessem construindo. A idéia de fragmentação era muito presente.

Em razão disso e observando segundo a perspectiva dos agentes que elaboraram o projeto de mestrado é possível, a partir da tipologia de Hart (1992), classificar o comportamento dos professores no tipo genérico, ou seja, são os empreendedores da ação. Queriam e tiveram a oportunidade de agir. Mas, a expectativa do comportamento dos gestores como patrocinadores (fomento e suporte) não foi constatada na condução do evento.

Deve-se ressaltar que apesar dos agentes do evento, em sua maioria, serem professores com pouco tempo de experiência no ensino superior público, souberam utilizar-se de práticas iterativas e políticas comuns nas ações estratégicas desenvolvidas nas universidades públicas, tais como: mobilização política, defesa de interesses, visão particular de um evento e utilização das regras em seu benefício. 
Conclui-se, segundo a visão geral do esquema analítico, que a ação estratégica surgiu de forma emergente, a partir de práticas iterativas e de relações culturais e sociais em um determinado grupo de agentes que foi se solidificando na interação e na formação de uma intersubjetividade que foi capaz de elaborar um projeto estratégico, o curso de mestrado, constituindo-se, retrospectivamente, como ação estratégica do episódio de criação e implantação da EACH.

40. Passo: Análise combinada com a abordagem de Van de Ven e Poole

Para a aplicação em pesquisas do esquema proposto em combinação com a abordagem de Van de Ven e Poole (1995; 2000) e Van de Ven (2003) sugere-se os seguintes passos:

1) Há necessidade de definir os subeventos relacionados ao evento foco, permitindo, dessa forma, uma visão geral do evento em estudo.

2) Seguindo o esquema proposto na tese é fundamental também especificar os agentes que participam do evento: os que tem poder de definir e executar a estratégia e aqueles que podem interferir no processo. Na abordagem de Van de Ven e Poole (1995) é possível considerar esses grupos diferentes como as entidades. Salienta-se, porém, que no evento em análise a observação do processo estratégico será feita a partir do pontode-vista de um grupo específico de gestores e professores.

3) O pesquisador em seguida deve determinar quais motores estão operando em um determinado evento, a partir das condições de operações dos motores apresentados.

4) Deve estabelecer também como eles estão relacionados ("casamento de modelos").

Como os itens 1 e 2 acima destacados já foram contemplados nas fases anteriores do esquema analítico, procede-se a análise dos itens 3 e 4 sugeridos pelos autores.

A ausência de departamentos, portanto de uma instância colegiada, levou à criação de outras estruturas na $\mathrm{EACH}$, como as comissões, porém, ainda pouco legitimadas pelos agentes na universidade. Configurou-se, então, no evento específico em análise, um grupo formado mais ou menos ao acaso, sendo iniciado por diálogos informais e processos iterativos nos quais a descoberta de afinidades em torno de interesses e sobre formas de pensar e de agir gerou forte coesão. Iniciou-se, em seguida, um processo mais estruturado no tempo e no espaço de subeventos que produziram a idéia e as ações que resultaram na elaboração de um projeto de mestrado. 
Pode-se julgar, de forma imediata, ter sido este um processo todo anárquico, porém, as características com o modelo de Cohen e March não conferem integralmente. Primeiro, os agentes pouco mudaram ao longo do processo. Segundo, após uma fase de conhecimento inicial dos agentes, foi se desenvolvendo a idéia de criar algo além de um grupo de pesquisa. Essa idéia inicia um processo teológico, pois, apesar de surgir sem ser planejada, sendo algo que emergiu da dinâmica do grupo, já apresentava alguns objetivos a serem alcançados segundo pode-se perceber na afirmação abaixo:

\footnotetext{
E13: Na verdade essa idéia [do curso de mestrado] surgiu do grupo de pesquisa, a gente começou a fazer uma série de seminários já em 2006, 2005/2006, interesses comuns, problemas de aplicação de física em sistemas sociais, começamos a conversar, fazer algumas pesquisas, começamos a produzir algumas coisas juntos, e a gente viu que existe uma tendência, estavam começando a surgir em alguns centros da Europa e dos Estados Unidos, estudos sobre sistemas complexos, e a gente achou então que podia criar isso aqui e ser um primeiro centro de referência, começando de um grupo pequeno, somos doze professores, e expandindo, criando algo que pode, a gente espera que tenha resultados importantes.
}

Inicia-se um processo dialético entre os membros do grupo e os outros atores da EACH, em especial os componentes da Congregação, o que resultou no projeto do curso. Esse processo dialético, porém, foi interrompido - por razões identificadas apenas parcialmente pela pesquisa, como o não reconhecimento de lideranças acadêmicas - por um processo de ciclo de vida, no qual o projeto do mestrado elaborado pelo grupo passa a transitar nos órgãos colegiados da EACH, da USP e da CAPES.

Conclui-se que - em razão das características dos agentes envolvidos (interesses, habilidades, competências e tempo dedicado à ação), dos sistemas organizacionais mobilizados (ou não) como a estrutura, a(s) cultura(s) e a liderança, das regras institucionais e da tradição histórica da USP e que constituíram um contexto específico de ação - foi possível constatar, ao longo da trajetória do evento de elaboração do mestrado em Sistemas Complexos da EACH, uma sequência dos modelos teleológico, dialético e ciclo de vida de Van de Ven e Poole, caracterizando ora um processo construtivo, ora um processo prescrito, mas não anárquico. 


\section{CONCLUSÃO}

Neste capítulo são apresentadas as conclusões da tese, procurando responder aos questionamentos de pesquisa a partir das evidências empíricas apreendidas e estruturadas por meio do esquema analítico.

Não há a intenção de indicar generalizações sobre processo estratégico em universidades públicas. O que se espera é a possibilidade de destacar aspectos capazes de ampliar a interpretação e explicação crítica do fenômeno na EACH e, dessa forma, contribuir para a ampliação do conhecimento teórico e prático sobre a temática.

A pesquisa teve como objetivo central elaborar um esquema analítico para ampliar a capacidade de análise, interpretação e explicação do processo estratégico ocorrido quando da criação e implantação de uma nova unidade universitária.

Ao desenvolver a análise do episódio de criação e implantação da EACH, confirmou-se a natureza complexa da universidade e o desafio que se apresenta aos pesquisadores e aos estrategistas tentarem compreender esse fenômeno.

A $\mathrm{EACH}$, unidade universitária objeto da pesquisa, mostrou-se como um conjunto social fortemente associado às ações conjunturais desenvolvidas em razão das características e dos interesses de grupos localizados. Porém, essas ações, de certo modo, mantêm-se integradas aos valores e crenças constitutivos da cultura integradora da USP e delimitadas em sua amplitude pelo grau de flexibilidade da estrutura e por fatores institucionais. Pode-se afirmar que integração, diversificação e fragmentação fazem parte dos processos de estruturação da unidade, entre os quais, o estratégico.

O esquema analítico elaborado e aplicado em dois eventos do episódio em análise, ao considerar a estratégia como um processo de/em estruturação em contextos nos quais se desenvolve a ação coletiva dos homens, mostrou-se como uma perspectiva analítica que permite retratar a complexidade da universidade e ampliar a interpretação e explicação desse processo. 
O esquema é capaz de contextualizar todas as instâncias e dimensões presentes nas ações estratégicas em uma universidade, contribuindo com as pesquisas analíticas e de intervenção no campo da sociologia das organizações educacionais.

O esquema também contribui com a teoria das organizações, entre outros aspectos, ao: a) reunir, em uma única estrutura, um processo de estratégia como concepção/projeto e um processo em construção contínua; b) retratar a estabilidade e a mudança em um fluxo de interações em tempos e lugares determinados; c) fundamentar teórica e empiricamente como ocorre a trama motriz entre agentes, sistemas organizacionais e contexto quando em uma ação estratégica; d) integrar perspectivas teóricas abrindo espaço para o avanço do conhecimento.

Após essa visão geral do problema de pesquisa, é possível elaborar as conclusões a partir das questões de pesquisa, ou seja, o que especificamente se propunha responder ao realizá-la.

\section{Sobre como pode ser caracterizado o processo de formulação e implementação da estratégia ocorrido quando da criação e implantação da EACH ?}

A estratégia constituiu-se claramente como um fluxo contínuo de ações desenvolvidas nos vários níveis organizacionais, acionadas por agentes em interação em contextos específicos e que, para tanto, manipularam sistemas organizacionais a partir de sua cognoscitividade, pautados em uma intenção definida em um projeto educacional. Apresentou-se como um processo que ocorre no longo prazo, no qual formulação e implementação são etapas entrelaçadas.

A tipologia apresentada por Nicolau (2001) na fundamentação teórica - estratégia racional, negociada e em construção permanente - mostrou-se mais ajustada às características do processo ocorrido na $\mathrm{EACH}$, desde que analisadas de forma complementar. Quando observado o episódio de criação e implantação da EACH, este se apresentou inicialmente como um projeto educativo, portanto, uma perspectiva racional deu partida ao processo. Mas, sua trajetória foi marcada também por ações negociadas e construídas localmente.

$\mathrm{O}$ evento 1 (elaboração do projeto da $\mathrm{EACH}$ ) demonstra que havia uma intenção clara de ampliar as vagas da graduação sem perda da qualidade acadêmica. Em um projeto inicial 
foram definidos os princípios, as diretrizes e os objetivos que deveriam nortear essa estratégia. Outras ações foram elaboradas em seguida; o projeto arquitetônico do novo campus e o projeto dos cursos, por exemplo. Algumas questões até a realização da pesquisa ainda não estavam claras, como: a falta dos departamentos provocou um vácuo de poder, as coordenações de cursos ficaram sobrecarregadas, a direção ficou sem apoio, portanto, padrões de funcionamento organizacional foram se constituindo ao longo da implementação do projeto.

O evento 2 (elaboração do projeto do curso de mestrado em sistemas complexos) apresentou características predominantemente de estratégia emergente, se tomarmos como referência o projeto da $\mathrm{EACH}$. Até o surgimento da ideia do curso de mestrado houve o predomínio de práticas iterativas próprias aos grupos de pesquisas em uma universidade (reuniões, apresentações de artigos, discussões, por exemplo). A ausência dos departamentos possibilitou a flexibilidade da estrutura e a emergência de um evento que se poderia considerar como dissonante em relação ao projeto da EACH.

Em ambos os eventos, as concepções de negociação e de construção social estiveram presentes, destacando-se os embates políticos e a negociação na tomada de decisão.

Percebeu-se que um fenômeno coletivo como o processo estratégico emerge por diferentes caminhos, não sendo estes universais na forma. Pode-se concordar com Glegg (2004) que analisar a estratégia em organizações complexas implica em permanente reflexão sobre os entrelaçamentos e a recriação mutuamente constitutiva de meios e fins. A questão não é separá-los ou simplificá-los, mas compreender suas complexas inter-relações.

Sobre quem são os agentes que participam diretamente do processo estratégico e quais elementos do contexto histórico, social e cultural e dos sistemas organizacionais são mobilizados pela ação destes agentes; como podem ser explicadas as inter-relações entre essas três dimensões?

Os agentes capazes de influenciar diretamente no processo foram os gestores do nível superior da universidade (evento 1) e docentes com interesses bem determinados que se 
potencializaram na interação ao constituírem-se como um grupo (evento 2). Os gestores de nível médio na USP e na EACH, nos eventos analisados, não tiveram muita influência.

Os resultados da tese permitem perceber a existência de elementos comuns que mobilizaram e nortearam o processo de geração e implantação das ações.

A cognoscitividade dos agentes, ou seja, saber atuar em determinados contextos usando (ou manipulando) as regras do jogo a favor de seus interesses, o que é claramente político, pode ser considerado no evento 1 (lideranças da USP) e no evento 2 (docentes da EACH), como um dos elementos fundamentais.

A flexibilização da estrutura também foi outro aspecto central. No evento 1, os líderes utilizaram-se de comissões e grupos de projetos que empreenderam as negociações no interior das unidades acadêmicas, possibilitando um melhor acompanhamento por parte da reitoria do desenvolvimento do projeto, a diminuição das resistências e o encurtamento do tempo de tramitação do projeto.

No evento 2, a ausência dos departamentos implicou no uso de estruturas não-formais (grupo de pesquisa) e de estruturas formais ainda sendo constituídas (comissão de pesquisa e pósgraduação), o que permitiu a organização de um grupo de forma mais flexível. Esta formação se apresentou como uma estrutura apropriada para o fazer estratégico, no qual professores sem uma função formal na hierarquia puderam utilizar-se de recursos individuais e organizacionais para a elaboração de uma proposta, o que resultou em um potencial evento na trajetória da $\mathrm{EACH}$.

A manipulação da cultura por meio do discurso simbólico das lideranças e a busca para obter legitimidade na sociedade, na universidade e por parte dos grupos de referência foram outros fatores influentes nos dois eventos analisados.

Em síntese, as ações estratégicas apresentaram-se diretamente relacionadas às condições contextuais, organizacionais e humanas existentes na USP. As características dos agentes, suas capacidades, valores, interesses e motivações, a tradição histórica e cultural e o uso inteligente dos sistemas organizacionais é que tornaram possível a implementação das ações. 
Esse processo pode seguir as intenções iniciais do projeto apenas em parte, mas a extensão desta coerência, conforme demonstrada na análise dos dois eventos, depende da capacidade dos gestores em identificarem o momento e o local propícios para intervirem sobre os eventos.

\section{Sobre se é possível definir alguns comportamentos dos gestores universitários que colaboram com o processo ou, ao contrário, dificultam a sua condução?}

O papel do gestor na condução do processo apresentou-se como fundamental na difusão dos valores presentes no projeto da $\mathrm{EACH}$ (evento 1). Em uma perspectiva interpretativa de Chaffee, os líderes foram hábeis em construir uma realidade por meio de processos de interação social e definiram a estratégia em princípios orientadores e diretrizes acadêmicas inovadoras que possibilitaram sua compreensão e aceitação pelos atores internos e externos à USP. Em uma perspectiva simbólica de Hart (quadro 4, p. 71) a cultura da USP foi habilmente manipulada pelos gestores, associando no projeto da $\mathrm{EACH}$ a responsabilidade social (ampliação do número de vagas) à inovação acadêmica presente no projeto (novos cursos, nova estrutura, ciclo básico, por exemplo).

Somaram-se a isso, o perfil acadêmico, o tempo despendido para a tarefa e o envolvimento dos gestores no processo, como forma de atenuar os conflitos e a tendência à inércia, próprios ao funcionamento da organização universitária, o que caracteriza o tipo transacional de Hart (quadro 4, p. 71).

Quando do evento 2, constatou-se uma participação muito limitada do diretor da EACH no processo, não sendo possível caracterizar sua conduta em nenhum dos tipos apresentados por Hart (quadro 4, p. 71). Uma leitura possível dessa postura é que ela permitiu o surgimento de um projeto inovador sem muita interferência. Mas, outra forma de interpretar pode sugerir que essa conduta da direção não foi capaz de influenciar determinado evento e tentar aproximá-lo das diretrizes do projeto da EACH. As consequências dessa posição da gestão sobre o projeto da Escola não podem ser previstas no momento.

Pode-se afirmar que para lidar com a ambiguidade desses eventos, os gestores devem possuir uma visão menos reificada da estratégia (DENIS et al, 2006) como um objeto manipulador da 
realidade organizacional. Podem, ao contrário, configurá-la a partir do fomento às ações que abrem caminhos para novas oportunidades e que representam interesses e motivações capazes de ativar forças motrizes-estruturais na organização. Em suma, a complexidade da universidade deve ser usada como fator de produção estratégica.

\section{Sobre como pode ser interpretado o processo à luz dos modelos e abordagens utilizados na análise da organização universidade e que conformidades e contradições podem ser detectadas?}

Constatou-se que os modelos de análise organizacional da universidade não se apresentam em suas formas puras ao longo da trajetória do fenômeno em estudo, mas sim, em uma realidade na qual atuam de forma intercambiável. A adoção de um único modelo impede que se compreenda como os eventos ocorrem de fato na instituição.

Confirmou-se, por outro lado, a capacidade explicativa dos modelos, podendo-se destacar alguns aspectos:

- Burocracia profissional, Mintzberg (2006): as estratégias representam o efeito cumulativo dos projetos ou das ações que seus membros estão em condições de convencer sobre sua implementação (evento 2); o poder dos dirigentes universitários em influenciar novas leituras da realidade para os agentes internos e para instituições externas, assim como, o uso do simbolismo para comunicar novos planos e obter legitimidade (evento 1).

- Adhocracia, Mintzberg (2006), Hardy e Fachin (2000): a reunião de profissionais em equipes multidisciplinares para que os recursos de diferentes especialidades possam ser agrupados com o objetivo de resolver os problemas existentes foi utilizada de forma eficiente no evento 1, na elaboração dos projetos dos cursos.

- Político, Baldridge (1977): a assertiva de que na universidade a prioridade é a participação e negociação, e seu processo decisório reflete muito mais um jogo político, no qual comissões e grupos emergentes funcionam e decidem a partir do conflito, negociações, coalizões e acordos é pertinente aos dois eventos analisados.

- Colegiado, Lima (2009): a utilização da estrutura colegiada para legitimar processos políticos de negociação (eventos 1 e 2). 
Na perspectiva do modelo de anarquia organizada, comumente relacionado à gestão das universidades, ao rever suas concepções, destaca-se que não se verificaria nenhuma coordenação na condução do processo estratégico. As decisões tomadas ligar-se-iam às dinâmicas do sistema, mas não seriam controladas dada a ausência de hierarquia, ou mesmo, à participação fluida na tomada de decisão e à legitimação por meio de processos colegiais. Ao considerar essas questões, não se poderia falar em estratégia, pois não haveria motores de mudança (VAN DE VEN, 1992) sendo acionados. O estudo de caso desenvolvido na tese não confirmou esse modelo como presente nos eventos analisados.

\section{Sobre se a experiência da EACH poderá colaborar com a criação e institucionalização de novas práticas administrativas e pedagógicas na universidade pública brasileira contribuindo para as tentativas de solução de suas crises; e quais proposições para a USP as conclusões da tese podem sugerir?}

Conforme apresentado ao longo da tese, o projeto acadêmico da $\mathrm{EACH}$, em consonância com a tradição da USP, deve pautar-se pela inovação e zelar pela qualidade do ensino, da pesquisa, da extensão e de serviços, que confere padrão de excelência à universidade. Deve atender à expansão do ensino médio e ampliar a diversidade de alunos na USP. A EACH deve ser uma escola em que professores e pesquisadores de várias áreas convivam em atmosfera de produção, disseminação e aplicação de conhecimento, sem fronteiras como barreiras. Os cursos devem oferecer aos alunos formação rigorosa e visão crítica da sociedade em que atuam como indivíduos, profissionais e cidadãos.

Constitui-se, dessa maneira, como um projeto arrojado no qual as crises de hegemonia, legitimidade e institucional citadas por Santos (1997) estão sendo enfrentadas.

A EACH vem enfrentando a crise de hegemonia da universidade inserindo suas atividades nas comunidades circundantes ao campus, propiciando a formação dos alunos na realidade profissional futura e integrando ensino, pesquisa, extensão e serviços ao seu projeto pedagógico por meio do ciclo básico e da metodologia de ensino baseado em problemas. 
Ao ampliar o número de alunos ingressantes oriundos da escola pública e da região leste de São Paulo e ao criar cursos no período noturno, reconheceu o direito desses alunos em frequentar um curso superior na melhor universidade do país e, ao mesmo tempo, fortaleceu sua legitimidade organizacional.

Ao elaborar internamente um projeto e negociar com o Governo do Estado seu financiamento, pode estabelecer um diálogo sem perda da autonomia, fortalecendo sua institucionalidade.

As inovações administrativas, como a ausência de departamentos, uma estrutura em dois níveis, uma maior flexibilidade estrutural e novas formas de relacionamento entre professores e gestores, professores e professores, professores e alunos pautaram-se nos princípios de ampliação da participação e da democracia na universidade. Requerem, porém, mais tempo para se consolidarem e mecanismos mais eficientes de reflexão na própria USP para reconhecer os avanços e conhecimentos obtidos com a experiência.

Se esses avanços sociais e acadêmicos irão se integrar à realidade do setor universitário brasileiro ainda é cedo para saber. Porém, se apresentam como inovadores e capazes de sinalizar um caminho promissor.

Respondendo ao segundo questionamento, destacam-se alguns aspectos percebidos ao longo da pesquisa no funcionamento interno da $\mathrm{EACH}$ e são sugeridas algumas proposições para a USP.

A nova unidade é um exemplo de que em uma universidade todo professor (ou grupo de), independentemente da área científica, pode ser um estrategista (agente), desde que haja flexibilidade estrutural na organização e que possa desenvolver habilidades nesse sentido. $\mathrm{O}$ evento da pós-graduação em sistemas complexos confirma essa assertiva. Porém, há de se encontrar um equilíbrio entre as ações emergentes de grupos autônomos (que permitem a inovação) e a estratégia pretendida. As características das lideranças acadêmicas sugeridas ao longo da tese e presentes no evento 1 podem contribuir para o alcance desse equilíbrio.

Percebeu-se, claramente, o fator influenciador que os valores, normas, regras e recursos da organização exercem sobre o processo. A criação e a implantação de um projeto na universidade pressupõem uma análise detalhada desses elementos internos. 
O isolamento de grupos ao longo do processo foi uma consequência constatada no episódio da criação e implantação da EACH. A formação de um vínculo acadêmico mais forte é possível, assim como a permanência desse vínculo. A gestão com ênfase na aprendizagem pode ajudar a incorporar mais pessoas aos grupos evitando a segregação em experiências isoladas. Isso poderia ser conseguido, por exemplo, por meio do estímulo às comunicações informais, o uso de tecnologias, bem como, pelo fomento à autocrítica nesses grupos por parte dos gestores.

O tempo de implantação do projeto mostrou-se uma variável importante. $\mathrm{Na} \mathrm{EACH}$ foram necessários cinco anos para a elaboração do primeiro curso de mestrado em um ambiente com mais de 150 doutores. Certo direcionamento estratégico pode ser capaz de diminuir esse tempo e manter uma maior coerência dos eventos com o projeto original.

Algo que se percebeu como fundamental para a efetivação da nova unidade foi a existência de agentes que incorporaram mais rapidamente em suas crenças os princípios do novo projeto. Isso ocorreu, principalmente, nos professores ingressantes. Sugere-se, em processos semelhantes, que os primeiros gestores até podem ser oriundos da organização, mas deveriam ser substituídos de forma mais imediata por professores ingressantes. A razão para isso é que a cultura integradora trazida pelos professores com mais tempo na organização pode inibir ações inovadoras necessárias ao processo de implementação.

A indissociabilidade entre ensino, pesquisa e extensão constitui um princípio cultural do setor universitário brasileiro. Na USP, a pesquisa assume um valor central que implica em reconhecimento aos professores e oportunidades na profissão. A administração universitária é vista como uma quarta função, sendo menos valorizada que as demais. A experiência da implantação da EACH mostrou claramente a interdependência entre as quatro atividades. Propõe-se que a avaliação dos docentes na universidade deva atender às dimensões de ensino, pesquisa, extensão e administração de forma mais equilibrada, motivando os professores a utilizarem suas capacidades e competências também na gestão.

A mesma atenção dada pela gestão superior quando da primeira etapa da implantação da EACH deveria ser mantida ao longo das demais etapas do processo (dada a característica de longo prazo da estratégia em organizações complexas), inclusive em relação à possibilidade 
de suas inovações serem difundidas para outras unidades da USP. Sugere-se que projetos inovadores desse tipo não podem ficar restritos a eles próprios, sua avaliação, por exemplo, deveria envolver toda a universidade, difundindo dessa forma experiências e conhecimento.

A experiência da EACH demonstra que a gestão de universidades pressupõe reconhecimento do gestor pelos seus pares e habilidades próprias de um líder acadêmico. A proposta de profissionalização da gestão enfatiza a dicotomia do administrativo do acadêmico, além de ampliar ainda mais a separação entre os níveis organizacionais, portanto, deve ser evitada. Há necessidade, porém, dos gestores conhecerem melhor os processos organizacionais ampliando sua capacidade de intervir no acadêmico. Constata-se que o gestor universitário é um agente especial no processo.

Algumas habilidades das lideranças universitárias constatadas no processo analisado podem ser destacadas: a) não homogeneizar o que é diverso, que possui uma lógica de ação própria condicionada por fatores interdependentes; b) saber lidar com a ideia de processo, utilizando a percepção e a experiência para desenvolver formas apropriadas de intervir; c) concordar com Baldridge que a universidade é um micro-sistema político, no qual a existência do conflito é prova da saúde institucional. A gestão nesse tipo de organização mostra-se política, portanto, influenciada pelos conflitos, a divergência de interesses, a concorrência pelos recursos e a permanente procura pelo alargamento de espaços de poder de grupos e de unidades;

Essa perspectiva de gestão implica em profundas mudanças na forma de agir das lideranças universitárias. Entre um gestor controlador e um que "tudo pode" há um espaço capaz de ser preenchido por um perfil simbólico, transacional e genérico. A única forma de gerenciar os eventos é participar do “jogo político".

Para finalizar, reafirma-se que o esquema analítico desenvolvido ao longo da pesquisa possibilitou a apreensão dos elementos envolvidos no processo estratégico e ofereceu uma alternativa analítica mais holística do fenômeno, integrando conteúdo, processo e resultados de uma estratégia, propiciando novas formas de interpretação e explicação.

Ficou demonstrado que a administração da educação é um processo. Os resultados e efeitos estão diretamente relacionados às trajetórias de eventos e suas conseqüências. Estes, por sua 
vez, ocorrem a partir da ação humana contextualizada e mediada por sistemas de regras e recursos organizacionais. Os fins e os meios são interdependentes.

Acredita-se que seja possível a aplicação do esquema em outras temáticas que confluem educação e administração, como a avaliação institucional e a aprendizagem organizacional, valorizando uma abordagem de processo e não de chegada ou de resultados pré-definidos.

Como limitações, além das questões já citadas na metodologia da pesquisa, pode-se constatar, primeiramente, que houve dificuldades, em razão do tempo da pesquisa, em determinar os resultados e efeitos do projeto EACH para a USP e para o setor universitário brasileiro.

Por segundo, um quinto passo na operacionalização do esquema poderia ser desenvolvido, no qual pudessem ser estabelecidas comparações entre os eventos, detalhadas as principais práxis resultantes e determinados os impactos dos eventos no fenômeno em estudo. Mas, isso implicaria em uma pesquisa longitudinal e fugiria aos objetivos da tese.

Como qualquer proposta teórica e prática, o esquema necessita de aperfeiçoamentos que podem seguir as seguintes recomendações:

- Continuidade de sua aplicação na própria $\mathrm{EACH}$, em outros eventos, em uma perspectiva longitudinal, com vistas a responder como a estratégia original se modifica ao longo do tempo;

- Aplicação do esquema analítico em outras universidades públicas e privadas e que possam contribuir para a validação do esquema;

- Utilização de outras metodologias de coleta e análise de dados, inclusive quantitativas, ampliando a capacidade analítica e interpretativa;

- Utilização de modelos analíticos da abordagem da estratégia como prática, como o proposto por Valmra et al (2006), na quarta etapa do esquema.

Acredita-se que ao propor um esquema analítico capaz de apreender e estruturar as dimensões constituintes de um processo estratégico, a tese propicia novos caminhos para que pesquisadores e estrategistas interpretem e conduzam, de forma mais efetiva, esse processo 
organizacional fundamental para o surgimento de uma nova universidade pública e para o desenvolvimento social. 


\section{REFERÊNCIAS}

ALCKMIN, Geraldo. A primeira universidade pública do "País" chamado Zona Leste. In: GOMES, Celso (Org.). USP Leste: a expansão da universidade do oeste para o leste. São Paulo: Edusp, 2005.

ALMEIDA, Martinho I. R. Planejamento estratégico para unidades e departamentos da USP: uma proposta de arquitetura, modelo e condução do processo. São Paulo, 2004. Tese de Livre-Docência em Administração. Universidade de São Paulo (USP). Faculdade de Economia, Administração e Contabilidade (FEA).

ALONSO, M. O papel do diretor na administração escolar. Rio de Janeiro: Bertrand, 1988.

ANTONELLO, Claudia S. A metamorfose da aprendizagem organizacional. In: RUAS, Roberto et al. Aprendizagem organizacional e competências. Porto Alegre: Bookman, 2005.

ARANTES, Valéria A. Articulação interdisciplinar entre conhecimentos científicos e gerais: o ciclo básico da USP leste. In: GOMES, Celso (Org.). USP Leste: a expansão da universidade do oeste para o leste. São Paulo: Edusp, 2005.

ARAUJO, Ulisses P. Entre o acadêmico e a gestão universitária: a construção de espaços, tempos e relações da USP Leste. In: GOMES, Celso (Org.). USP Leste: a expansão da universidade do oeste para o leste. São Paulo: Edusp, 2005.

ARGYRIS, C. Strategy implementation: an experience in learning. Organizational Dynamics, v. 18, n. 2, p. 5-15, 1989.

ASTLEY, Graham e VAN DE VEN, Andrew H. Debates e perspectivas centrais na teoria das organizações. In: CALDAS, M.; BERTERO, C. (Orgs.). Teoria das organizações. São Paulo: Atlas, 2007.

AYAS, Karen. Estruturação de projetos para a aprendizagem e a inovação. In: EASTERBYSMITH, M. et al. Aprendizagem organizacional e organização da aprendizagem: desenvolvimento na teoria e na prática. São Paulo: Atlas, 2001.

BALDRIDGE, J.V.,CURTIS, D.V., ECKER, G.P. and RILEY, G.L. Alternative models of governance in higher education. In: RILEY, G. and BALDRIDGE, J. (Orgs.), Governing academic organizations: new problems, new perspectives. Berkeley: McCutchan Pub., 1977. 
BALL, S.J.; BOWE, R. Subject departments and the "implementation" of National Curriculum policy: an overview of the issues. Journal of Curriculum Studies, London, v. 24, n. 2, p. 97-115, 1992.

BARBOUR, A.; CHRISPINIANO, J. Produtivismo, corrupção da ciência e controle do trabalho. Revista ADUSP, p. 44-50, outubro, 2009.

BARTUNEK, Jean M. Changing. Interpretive Schemes and Organizational Restructuring: The Example of a Religious Order. Administrative Science Quarterly, n. 29, p. 355-372, 1984.

BASTOS, Antônio. V. Cognição e ação nas organizações. In: DAVEL, E.; VERGARA, S. (Orgs.). Gestão com pessoas e subjetividade. São Paulo: Atlas, 2009.

BELL, D.; RAIFFA, H.; TVERSKY, A. Descriptive, normative and prescriptive interactions en decision making. In: BELL, D.; RAIFA, H.; TVERSKY, A. Decision making: descriptive, normative, and prescriptive interactions. Cambridge: Cambridge University Press, 1988.

BENSON, J. Organizations: a dialectic view. Administrative Science Quarterly, v. 22, p. $1-21,1977$.

BOURGEOIS, L. J. e BRODWIN, D. R. Strategic implementation: five approaches to an elusive phenomenon. Strategic Management Journal, v. 5, n. 3, p. 241-264, 1984.

BOURDIN, Alain. A questão local. Rio de Janeiro: DP\&A, 2001.

BRASIL. Ministério da Educação. Anteprojeto de Lei da Educação Superior. Brasília, 2005.

BRYMAN, Alan. Liderança nas Organizações. In: CLEGG et al. Handbook de Estudos Organizacionais, v. 3. São Paulo: Atlas, 2004.

BUARQUE, Cristovam. A refundação da universidade. Texto mimeo. Brasília, 2005.

BULGACOV, Sérgio. Administração estratégica: teoria e prática. São Paulo: Atlas, 2007.

BURAWOY, Michael. The extended case method. Sociological Theory, v. 16, n.1, mar., 1998.

BURREL, G.; MORGAN, G. Sociological paradigms and organizational analysis. London: Heinemann Educational Books, 1979. 
CANDIDO, Antônio. Reminiscências sobre as origens da USP. In: STEINER, J.; MALNIC, G. (Orgs.). Ensino superior: conceito e dinâmica. São Paulo: Edusp, 2006.

CANÁRIO, Rui. Estabelecimento de ensino: a inovação e a gestão de recursos educativos. In: NÓVOA, Antônio. (coord.). As organizações escolares em análise. Lisboa: Dom Quixote, 1992.

CARBONELL, Jaume. A aventura de inovar: a mudança na escola. Porto Alegre: Artmed, 2002.

CARRIERI, A. P.; SILVA, A. R. L.; JUNQUILHO, G. S. O fazer estratégia na gestão como prática social: Articulações entre representações sociais, estratégias e táticas cotidianas nas organizações. In: ENCONTRO ANUAL DA ASSOCIAÇÃO NACIONAL DE PÓSGRADUAÇÃO E PESQUISA EM ADMINISTRAÇÃO, XXXII, 2008, Rio de Janeiro. Anais... Rio de Janeiro: ANPAD, 2008.

CASTELLS, Manuel. A sociedade em rede. São Paulo: Ed. Paz e Terra, 2006.

CHAFFEE, E. E. Three models of strategy. Academy of Management Review, v. 10, n. 1, p. 89-98, 1985.

CHAKRAVARTHY, B.; DOZ, Y. Strategy process research: focus on corporate selfrenewal. Strategic Management Journal, v. 13, p. 5-14, 1992.

CHARMAZ, Kathy. A construção da teoria fundamentada: guia prático para análise qualitativa. Porto Alegre: Artmed, 2009.

CHAUI, M. S. Escritos sobre a universidade. São Paulo: Editora da UNESP, 2001.

CLEGG, S.; CARTER, C.; KORNBERGER, M. A máquina estratégica: fundamentos epistemológicos e desenvolvimentos em curso. Revista de Administração de Empresas RAE, v. 44, n. 4, p. 21-31, Out./Dez., 2004.

COCHIA, Camilla B. R.; MACHADO-DA-SILVA, Clóvis L. Ambiente, interpretação e estratégia em organizações paranaenses dos setores de vestuário e alimentos. Revista de Administração Contemporânea - RAC. Edição Especial, p. 11-35, 2004.

COELHO, Marco A. Lições e problemas da universidade - entrevista com Roberto Lobo. Revista Estudos Avançados, v. 6, n. 15, 1992.

COHEN, Michael D.; MARCH, James G., OLSEN, Johan P. A garbage can model of organizational choice. Administrative Science Quartely, v. 17, p. 1-25, 1972.

COLLIS, Jill; HUSSEY, Roger. Pesquisa em administração. Porto Alegre: Bookman, 2005. 
CORBUCCI, Paulo R. Desafios da educação superior e desenvolvimento no Brasil. Texto para discussão 1287. Instituto de Pesquisa Econômica Aplicada (IPEA). Brasília, 2007.

CRUBELlATE, João Marcelo. Parâmetros de qualidade de ensino superior: análise institucional em IES privadas do Estado de São Paulo. São Paulo, 2004. Tese (doutorado). Fundação Getúlio Vargas. Escola de Administração de Empresas de São Paulo.

CUNHA, Luis. A. A universidade brasileira: entre o taylorismo e a anarquia. Revista Brasileira de Educação, n. 10, p. 90-96, 1999.

CUNHA, C. J. C. A. Adaptação estratégica em ambiente turbulento. Florianópolis, 1996. Tese para Concurso de Professor Titular - Programa de Pós-Graduação em Engenharia de Produção - Departamento de Engenharia de Produção e Sistemas, Universidade Federal de Santa Catarina.

DAFT, R. I.; WEICK, K. Organizações como sistemas interpretativos: em busca de um modelo. In: Teoria das Organizações. CALDAS, M.P; BERTERO, C. O. (Orgs.). São Paulo: Atlas: 2007.

DE MASI, D. O futuro do trabalho: Fadiga e ócio na sociedade pós-industrial. Rio de Janeiro: José Olympio Editora, 2000.

DEMO, Pedro. Desafios modernos da educação. Petrópolis: Vozes, 1995.

DENIS, J. L.; LANGLEY, A.; ROULEAU, L Strategizing in pluralistic contexts: Rethinking theoretical frames. Human Relations, v. 60, n. 1, p. 179-215, 2007.

DENZIN, Norman K.; LINCOLN, Yvonna. O planejamento da pesquisa qualitativa. $2^{\mathrm{a}}$. Ed. Porto Alegre: Artmed, 2006.

DIMAGGIO, P. J.; POWELL, W. W. Jaula de ferro revisitada: isomorfismo institucional e racionalidade coletiva nos campos organizacionais. In: CALDAS, M.P; BERTERO, C.O. (Orgs.). Teoria das organizações. São Paulo: Atlas: 2007.

ELKJAER, Bente. Em busca de uma teoria de aprendizagem social. In: Aprendizagem organizacional e organização de aprendizagem. EASTERBY-SMITH, M. et al. (Orgs.) São Paulo: Atlas, 2001.

EMIRBAYER, M; MISCHE, A. What is agency? The American Journal of Sociology, v. 103, n. 4, p. 962-1023, 1998.

ETZIONI, Amitai. Análise comparativa de organizações complexas. Rio de Janeiro: Zahar Editora, 1974. 
FINE, Gary A. O melancólico declínio, o misterioso desaparecimento e o glorioso triunfo do interacionismo simbólico. In: Teoria das Organizações. CALDAS, M.P; BERTERO, C.O. (Orgs.) São Paulo: Atlas: 2007.

FISCHER, Rosa M. O Círculo do poder - As práticas invisíveis de sujeição nas organizações complexas. In: FLEURY, M.T.L.; FISCHER, R. M. Cultura e Poder nas organizações. São Paulo: Ed. Atlas, 2007.

FISCHMANN, Adalberto A.; ALMEIDA, Martinho I. R. de. Planejamento estratégico na prática. 2. ed. São Paulo: Atlas, 2007.

FONSECA, V.; MACHADO-DA-SILVA, C. Conversação entre abordagens da estratégia em organizações: escolha estratégica, cognição e instituição. Organização e Sociedade - O\&S, v.9, n.25, p. 93-109, set./dez., 2002.

FREITAS, Maria José: Contexto social e imaginário organizacional moderno. Revista de Administração de Empresas - RAE, v. 40, n. 2, p. 6-15, 2000.

FRIEDBERG, Erhard. O poder e a regra. Lisboa: Instituto Piaget, 1993.

GARAY, Lucia. A questão institucional da educação e as escolas: conceitos e reflexões. In: BUTELMAN, ida. Pensando as instituições: teorias e práticas em instituições. Porto Alegre: Artmed, 1998.

GIDDENS, Anthony. A constituição da sociedade. 2a . Ed. São Paulo: Martins Fontes, 2003.

GIL, Antônio Carlos. Como elaborar projetos de pesquisa. São Paulo: Atlas, 1994.

GLATTER, Ron. A gestão como meio de inovação e mudança nas escolas. In: NÓVOA, A. (coord.). As organizações escolares em análise. Lisboa: Dom Quixote, 1992.

GOMES, Celso de B. USP leste: a construção de um projeto participativo. In: GOMES, Celso (Org.). USP Leste: a expansão da universidade do oeste para o leste. São Paulo: Edusp, 2005.

GREENWOOD, R.; HININGS, C. Understanding radical organizational change: bringing together the old and the new institutionalism. Academy of Management Review. v. 21, n. 4, p. 1022-1054, 1996.

HABERMAS, Jurgen. A idéia da universidade: processos de aprendizagem. Revista Brasileira de Estudos Pedagógicos, v. 74, p. 111-130, 1993.

HALL, Richard. Organizações: estruturas, processos e resultados. São Paulo: Atlas, 2004. 
HARDY, Cynthia; FACHIN, Roberto. Gestão estratégica na universidade brasileira: teorias e casos. Porto Alegre: Ed. Universidade UFRGS, 2000.

HART, Stuart L. An Integrative framework for strategy-making processes. Academy of Management Review. v. 17, n. 2, p. 327-351, 1992.

HASSARD, J. Aspects of time in organization. Human Relations, v. 44, n. 2, p. 105-125, 1991.

HATCH, M. J. Organization theory: modern, symbolic and postmodern perspectives. Oxford: Oxford University Press, 2002.

HEGEL, Georg W. F. Introdução à história da filosofia. São Paulo: Hemus, 2003.

HERNES, Gudmund. Structural change in social process. The American Journal of Sociology, v. 38, n. 3, p. 513-547. 1976.

HOPKINS, D.; AINSCOW, M.; WEST, M. Fazendo a mudança ter sentido. In: PREDDY, M. et al. Gestão em educação: estratégia, qualidade e recursos. Porto Alegre: Artmed, 2006.

HREBINIAK, Lawrence G. Fazendo a estratégia funcionar. Porto Alegre: Bookman, 2006.

HUYSMAN, Marleen. Contrabalançando tendenciosidades: uma revisão crítica da literatura sobre aprendizagem organizacional. In: EASTERBY-SMITH, M. et al. Aprendizagem organizacional e organização da aprendizagem: desenvolvimento na teoria e na prática. São Paulo: Atlas, 2001.

JARZABKOWSKI, P.; WILSON, D. Top teams and strategy in a UK University. Journal of Management Studies, v. 39, n. 3, p. 355-381, 2002.

JUNQUILLO, Gelson S. Condutas gerenciais e suas raízes: uma proposta de análise à luz da teoria da estruturação. Revista de Administração Contemporânea - RAC, v. 7, Ed. Especial, p. 101-120, 2005.

KAPLAN, R. S. NORTON, D. P. The balanced scorecard: measures that drive performance. Harvard Business Review, v. 70, n. 1, p. 71-79, 1992.

KLASILCHIK, Mirian. Gestão - desafios e perspectivas. Revista USP. São Paulo: n. 78, p. 22-31, jun./ago., 2008.

. USP Leste: sonho e realidade. In: GOMES, Celso (Org.). USP Leste: a expansão da universidade do oeste para o leste. São Paulo: Edusp, 2005. 
KNIGHTS, D.; MORGAN, G. Corporate strategy, organizations and subjectivity: a critique. Organization Studies, v. 12, n. 2, p. 251-273, 1991.

LIMA, LICÍNIO. A Escola como organização educativa: uma abordagem sociológica. São Paulo, Cortez, 2008.

LOEBEL, Eduardo. Perspectivas estratégicas alternativas à teorias de posicionamento. Relatório de Pesquisa 1. São Paulo: FGV, 2005.

MACHADO-DA-SILVA, Clóvis L. Estratégia e organizações: conversação necessária. In: CLEGG et al. Handbook de Estudos Organizacionais, v. 3. São Paulo: Atlas, 2004.

FONSECA, V.; CRUBELLATE, J. Estrutura, agência e interpretação: elementos de uma abordagem recursiva do processo de institucionalização. Revista de Administração Contemporânea - RAC, v. 9, $1^{\text {a }}$. Edição Especial, p. 09-39, 2005.

MAINARDES, Jefferson. Abordagem do ciclo de políticas: uma contribuição para análise de políticas educacionais. Revista Educação e Sociedade, v. 27, n. 94, p. 47-69, 2006.

MARTIN, Joanne; FROST, Peter. Jogos de guerra da cultura organizacional: a luta pelo domínio intelectual. In: CLEGG et al (Orgs.). Handbook de Estudos Organizacionais, v. 2. São Paulo: Atlas, 2001.

MEIRELLES, Anthero M. Formação de estratégias no sistema bancário brasileiro. Belo Horizonte, 2003. Tese (doutorado). Universidade Federal de Minas Gerais. Faculdade de Ciências Econômicas.

MELFI, Adolpho J. A USP na zona leste. In: GOMES, Celso (Org.). USP Leste: a expansão da universidade do oeste para o leste. São Paulo: Edusp, 2005.

MENDES, José M. O. Perguntar e observar não bastam, é preciso analisar: algumas reflexões metodológicas. Faculdade de Economia da Universidade de Coimbra, 2010. Disponível em: <http://www.ces.uc.pt/publicacoes/oficina/194/194.pdf $>$. Acesso em: 22.09.2010.

MEYER Jr., Victor. Novo contexto e as habilidades do administrador universitário. In: MEYER Jr., V; MURPHY, J. P. Dinossauros, gazelas e tigres: novas abordagens da administração universitária. Florianópolis: Editora Insular, 2000.

MILLER, S. J.; HICKSON, D.J.; WILSON, D.C. A tomada de decisão nas organizações. In: CLEGG et al. Handbook de Estudos Organizacionais, v. 3. São Paulo: Atlas, 2004. 
MinTZBERG, H.; AHSTRAND, B.; LAMPEL, J. Safári de estratégia. Porto Alegre: Bookman, 2000.

Atlas, 2006.

Criando organizações eficazes: Estruturas em cinco configurações. São Paulo:

MORGAN, Gareth. Imagens da organização. São Paulo: Atlas, 1996.

MOTOYAMA, Shozo. USP 70 anos: imagens de uma história viva. São Paulo: Edusp, 2006.

MOTTA, F.C.; VASCONCELOS, I. G. Teoria geral da administração. São Paulo: Thomson Learning, 2006.

NICOLAU, Isabel. O conceito de estratégia. Working Paper 01-01, INDEG/ISCTE, 2001. Disponível em: http://iscte.pt/Estrategial/conceito\%20estrategia.pdf. Acesso em: 20/03/2010.

NONAKA, Ikujiro; TAKEUCHI, Hirotaka. Gestão do conhecimento. Porto Alegre: Bookman, 2008.

NÓVOA, Antônio. Para uma análise das instituições escolares. In: NÓVOA, A. (coord.). As organizações escolares em análise. Lisboa: Dom Quixote, p. 13-43, 1992.

OLIVEIRA, S.; SEGATTO, A. Transferência de tecnologia e conhecimento sob a lente estruturacionista: uma integração temática. Revista de Administração de Empresas - RAE (Eletrônica), v. 8, n. 2, jul./dez., 2009.

OLIVER, C. The antecedents of desinstitutionalization. Organization Studies, v, 13, n. 4, p. 563-588, 1992.

PEREIRA, Elizabeth M. de Aguiar. A universidade da modernidade nos tempos atuais. Avaliação, v. 14, n. 1, p. 29-52, mar. 2009.

PETTIGREW, Andrew M. Context and action in the transformation of the firm. Journal of Management Studies, v. 24, n. 6, p. 649-670, 1987.

A Cultura das Organizações é Administrável? In: Fleury, Maria Tereza L. et al. Cultura e Poder nas Organizações. São Paulo: Atlas, p. 145-153, 1989.

. The character and significance of strategy process research. Strategic Management Journal, v. 13, p. 5-16, 1992.

PFEFFER, Jeffrey; SALANCIK, Gerald R. Organizational decision making as political process: the case of a university budget. Administrative Science Quarterly, v. 19, n. 2, p. 135-152, Jun. 1974. 
PORTO, Cláudio; RÉGNIER, Karla. O ensino superior no mundo e no Brasil: condicionantes, tendências e cenários para o horizonte 2003-2025. Documento mimeo, 2005.

RANIERI, Nina. Autonomia universitária: as universidades públicas e a Constituição Federal de 1988. São Paulo: Edusp, 1994.

REED, M. The sociology of management. London: Harvester Wheatsheaf, 1989.

RODRIGUES, L. C.; RIEDI, A. M.; RISCAROLLI, V.; MACCARI, E. A. Plenitude institucional no ensino superior: uma análise das universidades do sistema ACAFE. VI Colóquio Internacional sobre Gestão Universitária na América do Sul. Anais. Blumenau, SC, 2006.

ROLLEMBERG, Marcelo (Org.). Universidade: formação e transformação. São Paulo: Edusp, 2005a.

A bússola que marca o leste. In: In: GOMES, Celso (Org.). USP Leste: a expansão da universidade do oeste para o leste. São Paulo: Edusp, 2005b.

SANTIAGO, R.; LEITE, D.; POLIDORI, M.; SARRICO, C. Modelos de governo, gerencialismo e avaliação institucional nas universidades. Revista Portuguesa de Educação, v. 16, n. 1, Braga - Portugal, p. 75-99, 2003.

SANTOS, Boaventura, S. Pela mão de Alice: o social e o político na pós-modernidade. São Paulo: Cortez, 1997.

SANTOS, L. L. da S.; SETTE, R. de S.; TURETA, C. A Estratégia como uma prática social: em busca do que seja "fazer estratégia". In: XXX ENCONTRO ANUAL DA ANPAD (2006: Rio de Janeiro). Anais... Rio de Janeiro: ANPAD, CD ROM, 2006.

SCHEIN, Edgar. H. Coming to a new awereness of organizational culture. Sloan Management Review. v. 25, n. 2, 1984.

SCHENDEL, Dan. Introduction to the summer 1992 special issue on 'strategic management research'. Strategic Management Journal, v. 13, p. 1-4, 1992.

SCHROEDER, Christine. Educação a distância e mudança organizacional na Escola de Administração da UFRGS: uma teoria substantiva. Porto Alegre, 2009. Tese (doutorado). Universidade Federal do Rio Grande do Sul. Escola de Administração.

SCHWANDT, Thomas. Três posturas epistemológicas para a investigação qualitativa: interpretativismo, hermenêutica e construcionismo social. In: DENZIN, N.; LINCOLN, Y. O Planejamento da pesquisa qualitativa. $2^{a}$. Ed. Porto Alegre: Artmed, 2006. 
SCHWARTZMAN, Simon. Universidades e desenvolvimento na América Latina: experiências exitosas de centros de pesquisa. Centro Edelstein de Pesquisas Sociais, 2008. Disponível em: <www.centroedelstein.org.br>. Acesso em: 06/06/2010.

. A Universidade de São Paulo e a questão universitária no Brasil. In: STEINER, J.; MALNIC, G. Ensino Superior: conceito e dinâmica. São Paulo: Edusp, 2008.

SCOTT, W. R.; MEYER, J. W. The organization of societal sectors: propositions and early evidence. In: POWELL, W. W.; DIMAGGIO, P. J. The new institutionalism in organizational analysis. Chicago: The University of Chicago Press, 1991.

SEVERINO, Antonio J. Ensino e pesquisa na docência universitária: caminhos para a integração. Cadernos de Pedagogia Universitária, v. 3, Pró-Reitoria de Graduação/ USP, 2008.

SEWELL, W. H. Jr. A theory of structure: duality, agency and transformation. The American Journal of Sociology, v. 98, n. 1. p. 1-29, 1992.

SZTOMPKA, Piotr. A sociologia da mudança social. Rio de Janeiro: Civilização Brasileira, 2005.

TAKAHASHI, A. R. W.; MACHADO-DA-SILVA, C. L. Ambiente, interpretação e estratégia: Estudo comparativo de casos em duas organizações escolares. In: XXVI ENCONTRO ANUAL DA ANPAD (2002: Salvador). Anais... Salvador: ANPAD, CD ROM, 2002.

UNIVERSIDADE DO ESTADO DO PARÁ - UEPA. Projeto pedagógico institucional. Belém, 2008.

UNIVERSIDADE DO ESTADO DE SÃO PAULO - USP. Faculdade de Economia, Administração e Contabilidade. Manual para formatação e edição de teses e dissertações. São Paulo, 2008.

UNIVERSIDADE DO ESTADO DE SÃO PAULO - USP. Anuário Estatístico 2010. São Paulo, 2010.

UNIVERSIDADE DO ESTADO DE SÃO PAULO - USP. Regimento geral da EACH. São Paulo, 2005.

UNIVERSIDADE FEDERAL DE UBERLÂNDIA. Lei de Diretrizes e Bases da Educação Nacional (n. 9394/96). Uberlandia, 1998. 
VALMRA, E.; METSLA, E.; RANNUS, R.; RILLO, M. Towards a practical model of strategy-as-practice. TUTWPE, n. 138, v. 18. p. 23-42, 2006. Disponível em: <http://deepthought.ttu.ee/majandus/tekstid/TUTWPE_06_138.pdf>. Acesso em: 12/10/2010.

VAN DE VEN, Andrew. Suggestions for studying strategy process: a research note. Strategic Management Journal, v. 13, p. 169-188, 1992.

POOLE, M. S. Explaining development and change in organizations. Academy of Management Review, v. 20, n. 3, p. 510-540. 1995.

ANGLE, H.; POOLE, M. Research on the management of innovation: The Minnesota Studies. Oxford: University Press, 2000.

2003.

Engaged Scholarship: A guide for organizational and social research. Oxford,

VASCONCELOS, I.; MASCARENHAS, A.; PROTIL, R. Paradoxos na gestão de pessoas: cultura e contexto em uma cooperativa agro-industrial. Revista de Administração Eletrônica - RAE, v. 3, n. 1, p. 1-19, Jan./jun., 2004.

VIEIRA, E.F. e VIEIRA, M.M.F. Funcionalidade burocrática nas universidades federais: conflito em tempo de mudança. Revista de Administração Contemporânea - RAC, v. 8, n. 2, p. 181-200, Abr.-Jun. 2004.

WEICK, Karl. E. Education systems as loosely coupled systems. Administrative Science Quarterly, v. 21, p. 1-9, 1976.

A psicologia social da organização. São Paulo: Edgar Blucher, Editora da Universidade de São Paulo, 1973.

Sensemaking in organizations. California: Sage, 1995.

WHITAKER, Randal. Gerenciando o contexto nos processos de conhecimento da empresa. In: A Gestão Estratégica do Capital Intelectual. KLEIN, David A., Rio de Janeiro: Qualitymark Ed., 1998.

WHIPP, Richard. Desconstrução criativa: estratégia e organizações. In: CLEGG et al. Handbook de Estudos Organizacionais, v. 3. São Paulo: Atlas, 2004.

WHITTINGTON, R. O que é estratégia? São Paulo: Thompson Learning, 2002.

The work of strategizing and organizing: for a practice perspective. Strategic Organization, v. 1, n. 1, p. 117-126, 2003. 
. Estratégia após o modernismo: recuperando a prática. Revista de Administração de Empresas - RAE, v. 44, n. 4, p. 44-53, 2004.

Completing the practice turn in strategy research. Organization Studies v. 27, n. 5, p. 613-634, 2006.

WILSON, David; JARZABKOWSKI Paula. Pensando e agindo estrategicamente: novos desafios para a análise estratégica. Revista de Administração de Empresas - RAE, v. 44, n. 4, p. 11-20, 2004.

YIN, Robert K. Estudo de caso: planejamento e métodos. 2. ed. Porto Alegre: Bookman, 2005.

ZABALZA, Miguel A. O ensino universitário: seu cenário e seus protagonistas. Porto Alegre: Artmed, 2004.

ZARIFIAN, Philippe. Comunicação e subjetividade nas organizações. In: DAVEL, E.; VERGARA, S. (Orgs.). Gestão com pessoas e subjetividade. São Paulo: Atlas, 2009. 


\section{APÊNDICES}

Apêndice 1: Roteiro de entrevista semi-estruturada - Evento 1 - Dirigentes da USP Apêndice 2: Roteiro de entrevista semi-estruturada - Evento 2 - Professores do mestrado em sistemas complexos da EACH 


\section{Apêndice 1: Roteiro de Entrevista - Evento 1 - Dirigentes da USP}

O roteiro constituiu-se de perguntas sobre a trajetória do processo de elaboração e implantação das EACH que ocorreu na USP no período analisado por esta pesquisa. As questões procuraram contemplar os constructos apresentados no quadro 7, contexto histórico, social e cultura, sistemas organizacionais, agentes, ação, interação, intersubjetividade, núcleomotriz, práxis. A sequência das questões sofreu alterações em cada entrevista.

\begin{tabular}{|l|}
\hline Breve relato de vida profissional \\
\hline Tempo de trabalho na USP/EACH \\
Fatos marcantes ao longo da carreira na USP \\
Cargos ocupados pelo entrevistado (a) \\
Formação escolar (graduação e pós-graduação) \\
Que motivos o levaram a participar da criação da EACH? \\
\hline
\end{tabular}

\footnotetext{
Questões

1) Como surgiu a proposta da EACH?

2) Em sua opinião, quais as justificativas para a criação da EACH?

3) Quais os agentes principais envolvidos no processo?

4) De que forma ocorreu esse envolvimento?

5) A proposta se objetivou como projeto? Caso afirmativo, quais os princípios e diretrizes estratégicas definidos?

6) Nas discussões durante a elaboração procurou-se estabelecer relação com fatos históricos ocorridos na USP?

7) Para a elaboração da proposta vocês se basearam em alguma experiência anterior ou de fora da USP?

8) Houve dificuldades impostas por normas da universidade ao projeto? Caso afirmativo, quais foram?

9) Quais valores da universidade, em sua opinião, prevaleceram na proposta?

10) Como foram formadas as comissões?

11) Quais foram os critérios de escolha das pessoas?

12) Como ocorriam as reuniões nessas comissões? Qual a periodicidade?

13) Como o Governador recebeu a proposta? O Governo cumpriu com o acordado?

14) Quais as principais dificuldades durante o processo de elaboração da proposta?

15) Como o processo foi divulgado na universidade?

16) Houve resistências internas?

17) Como foi o trâmite nos colegiados da USP?

18) Houve resistências no Conselho Universitário? Caso afirmativo, de que forma lidou-se
} 
com essa resistência?

19) Como ocorreu o contato com a comunidade da Zona Leste?

20) Quais os cursos que a comunidade pleiteava?

21) Como foram definidos os cursos da EACH?

22) Qual a sua avaliação do processo de implantação?

23) O que você faria diferente?

24) Em sua opinião, quais os resultados alcançados até o momento? 


\section{Apêndice 2: Roteiro de entrevista - Evento 2 - Professores do mestrado em sistemas complexos da EACH}

O roteiro constituiu-se de perguntas sobre a trajetória do processo de elaboração do mestrado em Sistemas Complexos que ocorreu na EACH no período analisado por esta pesquisa. As questões procuraram contemplar os constructos apresentados no quadro 7, contexto histórico, social e cultura, sistemas organizacionais, agentes, ação, interação, intersubjetividade, núcleomotriz, práxis. A sequência das questões sofreu alterações em cada entrevista realizada.

\begin{tabular}{|l|}
\hline Breve relato de vida profissional \\
\hline Tempo de trabalho na USP/EACH \\
Experiência no ensino superior \\
Motivos que o levaram a ingressar na EACH \\
Cargos ocupados pelo entrevistado (a) \\
Formação escolar (graduação e pós-graduação) \\
\hline
\end{tabular}

\footnotetext{
Questões

1) Em sua opinião, quais os principais desafios na implementação de um projeto estratégico como a EACH em uma universidade como a USP?

2) Quais as questões contextuais (tanto externas como internas) para você que mais interferem no projeto da $\mathrm{EACH}$ ?

3) A nova estrutura e os processos administrativos da nova unidade $(\mathrm{EACH})$ (tipo: liderança, gestão de pessoas, tecnologia, outras) contribuem para a efetivação da proposta?

4) Em sua opinião, quais as atividades dos agentes (gestores, professores) que mais contribuem para a efetivação do projeto?

5) Há na EACH mecanismos que facilitem a interação entre agentes e que estimulem o processo de revisão das ações ou dos projetos propostos?

6) No caso específico do curso de mestrado em sistemas complexos, como surgiu a idéia? Havia uma proposta desenhada anteriormente ou houve debates de várias idéias até se chegar a um consenso?

7) Quais os aspectos principais da proposta?

8) Quais os valores e crenças mais presentes nas discussões e que influenciaram o processo?

9) Houve preocupação em ajustá-la ao projeto da EACH?

10) Em sua opinião, o que levou essas pessoas (os professores do curso) a interagirem, em determinado momento? Quais as questões que as uniu? Estímulos comuns, socialização, ou outras?

11) Como foram desenvolvidas as reuniões? Havia uma pauta? Quem coordenava? De que forma era exercida esta coordenação? $\mathrm{Ou}$ as discussões começaram por contatos informais?
} 
12) Como as informações para as discussões eram obtidas? A partir do conhecimento dos participantes, pelo conhecimento de outras experiências na própria universidade ou por meio de conhecimento registrado de outras experiências da EACH?

13) Houve participação de professores de outras unidades da USP? Ou de outras instituições? Se afirmativo, como ocorreu o convite?

14) Como ocorreu a comunicação entre os participantes? Face-to-face, uso de tecnologias, ou outros meios?

15) Em sua opinião a estrutura da EACH contribui para processos desse tipo ou restringe? Se positivo, quais as características estruturais e processuais da $\mathrm{EACH}$ que facilitam esse tipo de interação?

16) Qual o papel da Direção da EACH no processo de elaboração do curso?

17) Do ponto de vista do contexto quais as questões que mais interferiram no desenvolvimento do projeto de mudança curricular? (o contexto é constituído por aspectos históricos, normativos, regulatórios, etc. Por exemplo, as normas da USP ou da própria EACH interferiram de que forma quando da intenção de professores em propor um curso de mestrado?)

18) Essa interferência foi positiva ou negativa para a implementação?

19) Como se efetiva a participação dos indivíduos no processo? O grupo se expande ou diminui com o tempo? Uns participam mais do que os outros?

20) Em sua opinião, a questão do surgimento de uma proposta significou um acordo coletivo de que aquela é a melhor proposta ou de que é a possível de ser feita? Ou ainda, trata-se da proposta defendida pelo grupo de maior poder?

21) Quais as razões para que outros grupos não tenham procedido da mesma forma que vocês? Quais as características do grupo que permitiram a construção da proposta?

22) Em sua opinião quais os resultados obtidos até agora com a implementação da proposta? Novas regras de conduta de professores e alunos, novas formas de avaliação, novos procedimentos pedagógicos, novas formas de controle, novas maneiras de pensar, outros?

23) Como essa experiência está sendo transferida para o restante da EACH? A aceitação está sendo positiva? É possível que ela passe a integrar o projeto estratégico da unidade? 